$$
\begin{gathered}
\text { Universidade de São Paulo - USP } \\
\text { Museu de Arqueologia e Etnologia - MAE } \\
\text { Programa de Pós-Graduação em Arqueologia }
\end{gathered}
$$

Agatha Rodrigues da Silva

\title{
A Arqueologia da África através dos Editoriais: uma análise dos discursos arqueológicos de africanos e africanistas nos boletins especializados
}

Orientadora: Prof. ${ }^{\underline{a}}$ Dr. ${ }^{\stackrel{a}{ }}$ Marta Heloísa Leuba Salum

São Paulo

2013 
Agatha Rodrigues da Silva

\title{
A Arqueologia da África através dos Editoriais: uma análise dos discursos arqueológicos de africanos e africanistas nos boletins especializados
}

\begin{abstract}
Dissertação de Mestrado apresentada ao Programa de Pós-Graduação em Arqueologia do Museu de Arqueologia e Etnologia da Universidade de São Paulo para a obtenção do título de Mestre em Arqueologia.
\end{abstract}

Versão corrigida. A versão original encontrase na biblioteca do MAE.

Área de Concentração: Arqueologia

Orientadora: Prof. ${ }^{a}$ Dr. ${ }^{\underline{a}}$ Marta Heloísa Leuba Salum

Linha de Pesquisa: Cultura Material e Representações Simbólicas em Arqueologia

São Paulo

2013 


\section{RESUMO}

As sociedades e instituições arqueológicas, como as demais organizações científicas, são espaços fundamentais no fomento e na manutenção da rede de intelectuais de sua área de pesquisa. Podem, através da veiculação de suas publicações, apontadas na seção editorial de boletins dessas organizações, reafirmar as tradições arqueológicas ou oferecer perspectivas inovadoras. Analisamos trinta e quatro editoriais das publicações The South African Archaeological Bulletin, Nyame Akuma e Nsi, intentando compreender a formação das múltiplas imagens dos arqueólogos africanos e africanistas na era pós-colonial, entre 1987 e 1993, que, a nosso ver, dar-se-ia diante daquilo que essas sociedades através de seus boletins consolidam.

Segundo a ótica de seus editores, os boletins do corpus de nossa pesquisa eram meios de comunicação rápidos e eficientes para cumprir funções de possibilitar que os arqueólogos interagissem, que se informassem sobre o andamento das pesquisas de campo e que fossem comunicados quanto à realização de congressos entre seus pares.

Nosso recorte temporal define-se pela circulação concomitante dos três boletins, exceto quanto ao Nsi, que foi, um ano antes, em 1992, assimilado ao Nyame Akuma. Esse recorte temporal, a propósito, foi marcado pelas correntes teóricas da Nova Arqueologia, do Pós-Processualismo, dos estudos póscoloniais e pela divulgação da pesquisa arqueológica na África e sobre a África em face dessas abordagens.

Apontamos a título de conclusão da análise que os boletins, sob o pretexto de favorecer os arqueólogos e a produção científica em arqueologia na África durante esse período, veiculavam, na verdade, as imagens ideais ou mesmo as rechaçadas dos arqueólogos interessados na África. Essas imagens eram construídas nos textos dos editores na prática discursiva que formulavam com temas ligados ao ofício do arqueólogo.

\footnotetext{
PALAVRAS-CHAVES: África Austral - África Central - Comunicação científica: Arqueologia - "Descolonização da Arqueologia Africana" História da Arqueologia
} 


\begin{abstract}
The archaeological societies and institutions, like others scientific organizations, they are fundamental spaces in the encouragement and in the support an intellectual's network of the research's area. They can, through the distribution of its publications, like the newsletters, in the editorial section, to reaffirm traditions or offer innovative perspectives. We analyzed thirty and four editorial texts in The South African Archaeological Bulletin, Nyame Akuma and Nsi, intending to understand structure multiple images' of Africans and Africanists Archaeologists in the post-colonial era, between 1987 and 1993, that, in our opinion, would it is happen before of that societies through its newsletters consolidate.
\end{abstract}

According to the viewpoint their editors, the newsletters of our documental corpus were agile and efficient to fulfill the functions to make possible archaeologists interact, they knew about the fieldwork's progress, they were informed about the realization of Congress. Our temporal period is defined by the concomitant movement of the bulletins, with the exception of the year 1993, when Nsi was assimilated to Nyame Akuma. It's a period was marked by New Archaeology's theoretical currents, Post-processualism, postcolonial studies and dissemination of archaeological research in the Africa and about the Africa in face of these approaches.

We point as conclusion of the analysis like the bulletins, under the pretext of promoting the archaeologists and the scientific archeology in the Africa, during in this period, they conveyed, in fact, the ideal or rejected images of the interested archaeologists in Africa. These images were constructed in the editor's texts in discursive practice that they formulated. They were recurring statements of the contingent themes at the archaeologist's work.

KEYWORDS: Southern Africa - Central Africa - Scientific Communication: Archaeology - "Decolonization of African Archaeology" - History of the Archaeology 


\section{AGRADECIMENTOS}

Em primeiro lugar gostaria de agradecer aos meus pais João e Anita que me proporcionaram muitas oportunidades de estudo e aprimoramento pessoal. Muitas vezes não pude visitá-los em razão das horas destinadas às leituras e digitação e ainda, assim, eles incentivaram-me muito a seguir em frente.

Agradeço imensamente ao Anisio, o meu Bem, que nesses anos de mestrado alegremente me incentivava e solidariamente tocava baixinho o seu violão ritmando as minhas horas de leitura e digitação. Alguns dias antes da defesa eu descobri que estava grávida. Assim, também agradeço a esse abençoado espírito que me escolheu como mãe para orientá-lo nesse mundo.

Sou sinceramente grata aos meus colegas de trabalho, professores da educação de jovens e adultos, e à equipe técnica da minha escola, que tanto me incentivaram quanto se solidarizaram comigo em minhas longas jornadas de estudo alternadas com as de ensino na rede municipal. Agradeço muito a Prof ${ }^{a}$ Bete Fekete que fez a revisão entusiasmada desta dissertação.

Obrigada aos funcionários da biblioteca do MAE que me auxiliaram nas minhas buscas eletrônicas intermináveis, particularmente a Hélio Rosa de Miranda que, em seu trabalho, parece acabar estudando com os estudantes, compartilhando daquilo que acaba conosco lendo a respeito do nosso assunto. Obrigada a quem inventou o acesso eletrônico remoto VPN que ajuda muito as pessoas que, como eu, moram muito longe da Universidade, têm vínculo empregatício e ainda pesquisam um tema, a arqueologia africana, com bibliografia ainda muito restrita no Brasil.

Nesse sentido não posso deixar de agradecer a algumas pessoas muito importantes, como os autores dos editoriais do corpus documental, que me proporcionaram muito trabalho nesses anos, e os autores da minha bibliografia, a quem sou muito grata por terem divulgado o seu conhecimento e, assim, contribuído para a realização desta dissertação.

Agradeço a duas queridas professoras minhas - as duas que também fizeram parte da minha banca de qualificação trazendo leitura atenta e recomendações muito importantes para o prosseguimento de meus estudos, cuja resposta, certamente, se reflete na redação final desta dissertação - pelo menos assim espero ter podido fazer. Falo da Professora Cristina Wissenbach, de quem fui aluna na graduação em História; e, da Professora Elaine Hirata, de quem fui aluna na disciplina Teoria Arqueológica do PPGArq, e do seu jeito muito especial de enxergar as coisas, apontando problemas e abrindo caminhos entusiasmantes para mim. Agradeço imensamente a banca de defesa composta pela Professora Elaine Hirata e, em especial, pelo Professor Kabenguele Munanga, pelo qual tenho grande admiração, e que fez uma leitura cuidadosa dessa dissertação. Espero que essa versão revisada tenha contemplado os preciosos comentários e sugestões da banca.

Por fim, agradeço a minha orientadora Lisy que cuidou muito de mim nesses anos, mesmo antes do mestrado, na minha graduação em História. Com imenso coração orientou-me com prazer e olhos brilhando. Muito obrigada Lisy. 
O miúdo Ihes chamava ao presente. Quer saber o que animava Nhamataca, covando assim.

- Estou a fazer um rio, responde o outro.

Riem-se, o rapaz e Tuahir. Mas o homem insiste sério. Sim, por aquele leito fundo haveria de cursar um rio, fluviando até ao infinito mar. As águas haveriam de nutrir as muitas sedes, confeitar peixes e terras. Por ali viajariam esperanças, incumpridos sonhos. E seria o parto da terra, do lugar onde os homens guardariam, de novo, suas vidas.

Estava tão seguro que começara por escavar o chão da própria casa. Ruíram as paredes, desabou-se o tecto. Os seus se retiraram em dúvida da sua sanidade. Ido os próximos, irados os distantes. O sujeito desafiava os deuses que aprontaram o mundo para os viventes dele só se servirem, sem ousarem mudar a sua obra. Mas Nhamataca não desistiu, covando dia e noite. Foi seguindo, serpenteando entre vales e colinas, suas mãos deitando e renovando mil vezes as sangradas e calejadas peles. E agora, sentado na ribanceira, guarda com vaidade a sua construção. Aponta o fundo:

- Vejam já desponta um fiozinho de água.

(COUTO, Mia. 2007. Terra Sonâmbula. SP: Cia das Letras, p. 85-86) 


\section{SUMÁRIO}

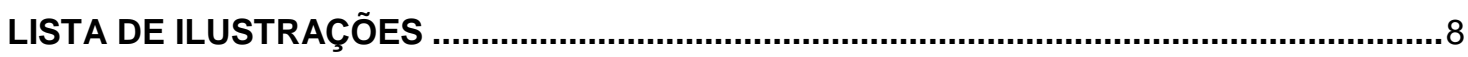

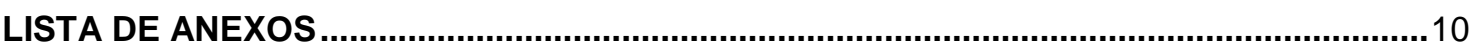

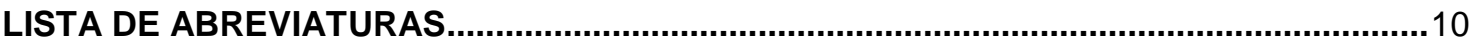

APRESENTAÇÃO

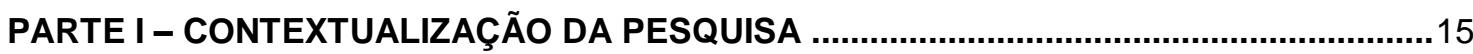

1 FUNDAMENTOS METODOLÓGICOS PARA A ANÁLISE DO CORPUS ......................16

SOBRE AFRICANOS E AFRICANISTAS ……….................................................. 16

A CONSTITUIÇÃO DO CORPUS DOCUMENTAL ................................................ 18

REFERENCIAIS TEÓRICOS .........................................................................22

SOBRE AS IMAGENS DOS ARQUEÓLOGOS AFRICANOS E AFRICANISTAS ..........42

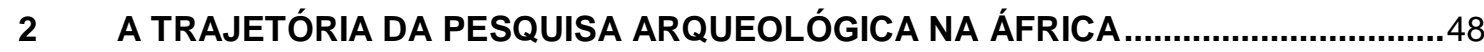

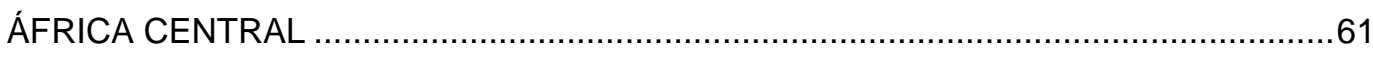

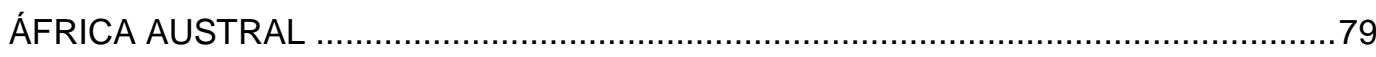

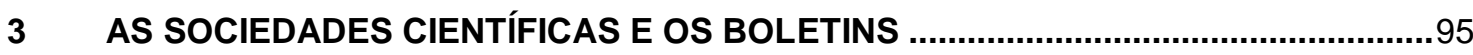

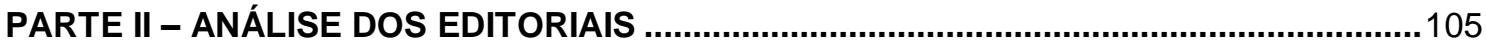

4 THE SOUTH AFRICAN ARCHAEOLOGICAL BULLETIN......................................106

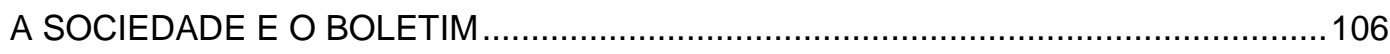

OS EDITORIAIS E OS EDITORES .................................................................. 116

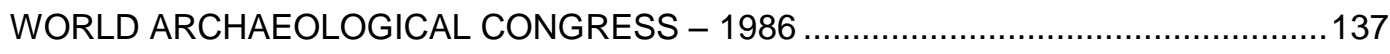

$5 \quad$ NYAME AKUMA - DE “NEWSLETTER” A “BULLETIN” ........................................143

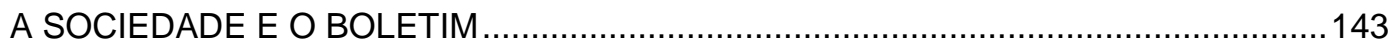

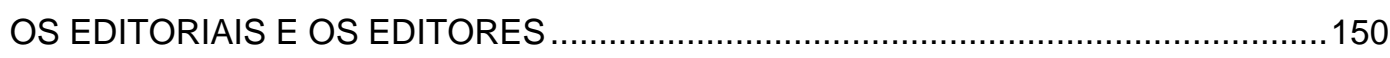

PARA QUE SERVE O “NEWSLETTER”, E POSTERIOMENTE, O “BULLETIN”? ......... 165

6 NSI - BULLETIN DE LIAISON DES ARCHÉOLOGUES DU MONDE BANTU ............171

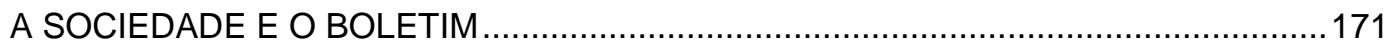

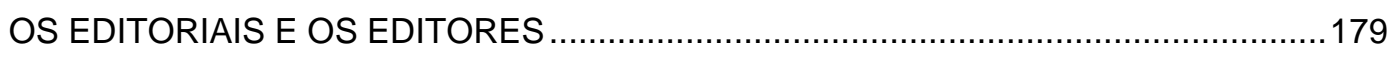

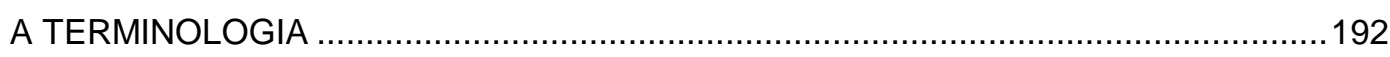


7 ARQueólogos: UMA tentativa de ARTICULAÇÃo DAS IMAGENS CONSTRUÍDAS ............................................................................................... 195

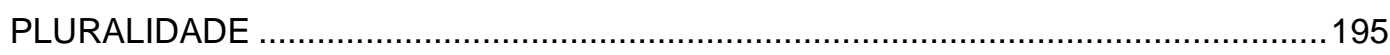

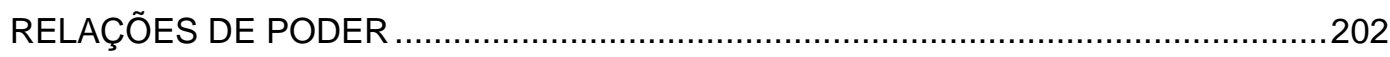

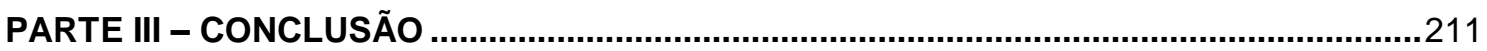

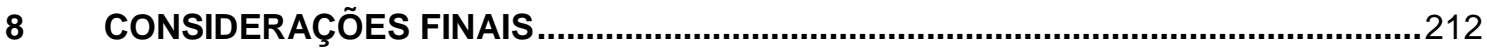

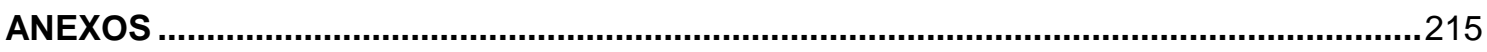

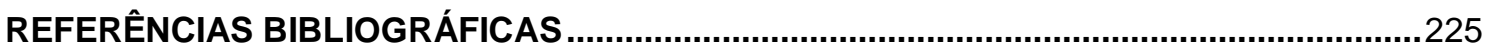

\section{LISTA DE ILUSTRAÇÕES}

\section{GRÁFICOS}

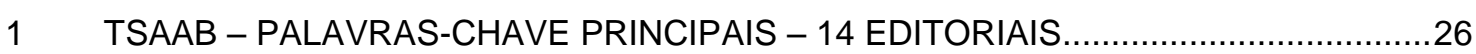

2 TSAAB - PALAVRAS-CHAVE SECUNDÁRIAS - 14 EDITORIAIS ................................27

$3 \quad$ N.A. - PALAVRAS-CHAVE PRINCIPAIS - 13 EDITORIAIS …..................................2

4 N.A. - PALAVRAS-CHAVE SECUNDÁRIAS - 13 EDITORIAIS ....................................28

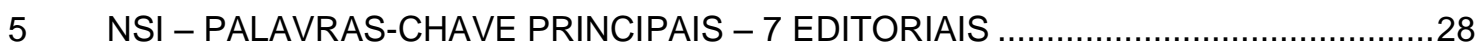

$6 \quad \mathrm{NSI}$ - PALAVRAS-CHAVE SECUNDÁRIAS - 7 EDITORIAIS .....................................29

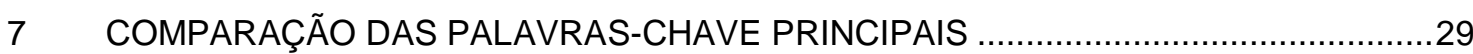

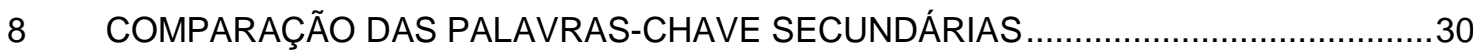

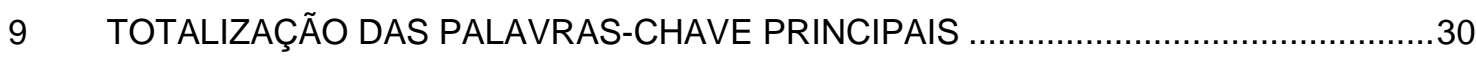

10 TOTALIZAÇÃO DAS PALAVRAS-CHAVE SECUNDÁRIAS .............................................

\section{MAPAS}

1 DISTRIBUIÇÃO DO BOLETIM NSI ENTRE 239 PESQUISADORES E INSTITUIÇÕES DE PESQUISA ENTRE OS ANOS DE 1987-1991 .................................................37

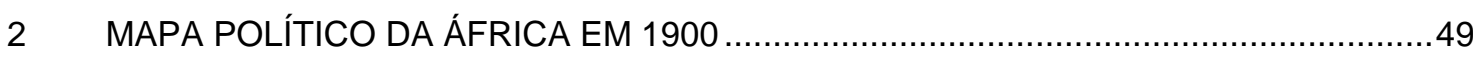

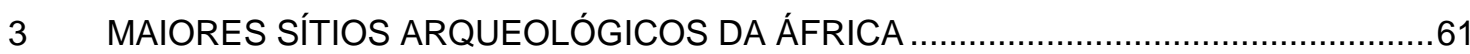

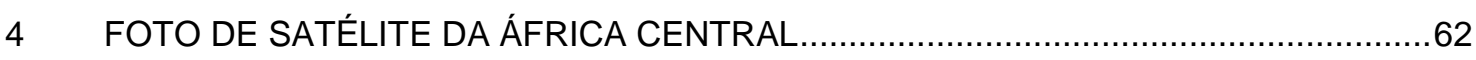

5 UM DOS MODELOS DE ORIGEM E DAS ROTAS DE MIGRAÇÃO DOS POVOS DE

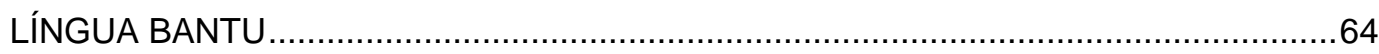

6 ALGUNS SÍTIOS ARQUEOLÓGICOS DA ÁFRICA CENTRAL .....................................65 
7 ÁFRICA AUSTRAL - FRONTEIRAS POLÍTICAS INTERNACIONAIS E PROVÍNCIAS DA

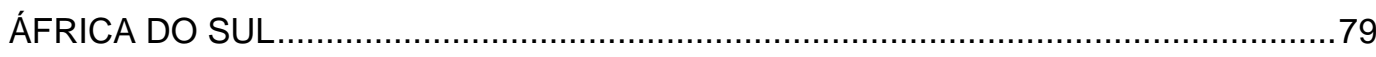

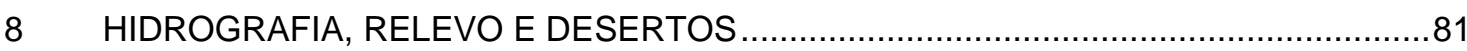

9 ALGUNS SÍTIOS ARQUEOLÓGICOS DA ÁFRICA AUSTRAL ....................................92

\section{FIGURAS}

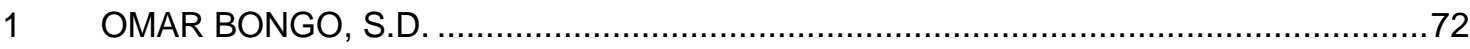

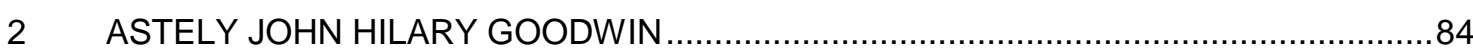

3 REPRESENTAÇÃO dOS ARTEFATOS LíticOS dOS PERÍOdOS E.S.A., M.S.A. E L.S.A. 85

4 O ARQUEÓLOGO VAN RIET LOWE, SENTADO À ESQUERDA, FIGURA - O GENERAL JAN SMUTS, SENTADO AO LADO DE LOWE, E A EQUIPE DE ESCAVAÇÃO NO SÍTIO EM MAPUNGUBWE, 1930 .88

5 CAPA E PARTE DO EDITORIAL DO PRIMEIRO NÚMERO DO TSAAB, DEZEMBRO DE 1945 108

6 JANETTE DEACON MINISTRANDO CURSO PARA A FORMAÇÃO DE GUIAS DO

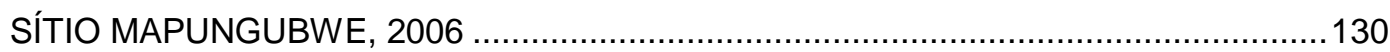

7 ENTRADA DO SÍTIO NELSON BAY CAVE, LOCALIZADO EM WESTERN CAPE, ÁFRICA DO SUL 131

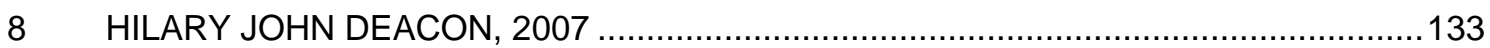

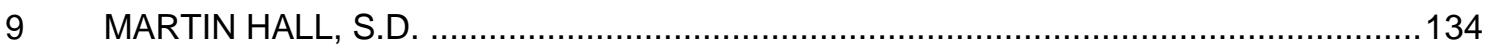

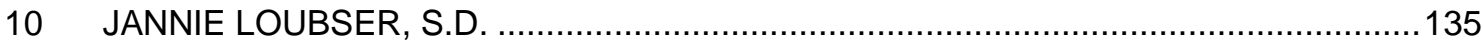

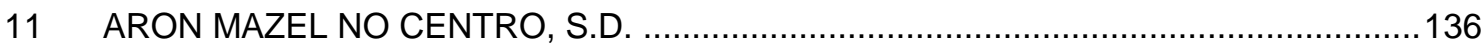

12 TRECHO DO PRIMEIRO EDITORIAL DO NA, OUTUBRO DE 1972 ............................146

13 DUAS ILUSTRAÇÕES DOS ARTEFATOS CHAMADOS NYAME AKUMA-GOD-AXE .147

14 CAPA DA PRIMEIRA EDIÇÃO DE OUT. 1972 E TRECHO DO EDITORIAL DO NA, N.32, DEZ. DE 1989, COM LOGOMARCA

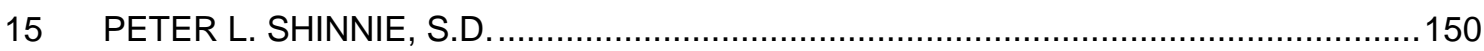


17 JOHN R. F. BOWER, S.D.

18 REPRODUÇÃO DA CAPA E DO TRECHO DE UM EDITORIAL DO NSI

19 DETALHE DAS PRESAS DE ELEFANTE PRESENTES NAS CAPAS DO NSI E NA FACHADA DO CICIBA.

20 REPRODUÇÃO DA TABELA DE DIFUSÃO DOS PERIÓDICOS DE ARQUEOLOGIA AFRICANA NOS ESTADOS-MEMBROS.

21 CHEIKH ANTA DIOP, À ESQUERDA E THÉOPHILE OBENGA, À DIREITA (1981) ....186

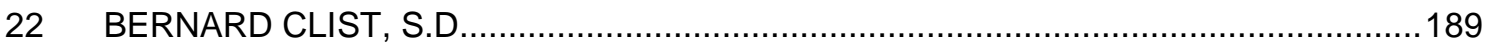

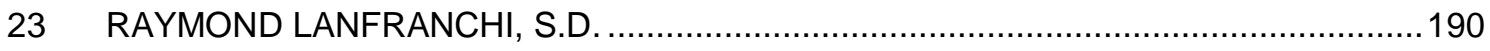

\section{LISTA DE ANEXOS}

\section{TABELAS}

PALAVRAS-CHAVE PRINCIPAIS

PALAVRAS-CHAVE SECUNDÁRIAS.

BASE DE DADOS

\section{LISTA DE ABREVIATURAS}

- CICIBA - CENTRE INTERNATIONAL DES CIVILISATIONS BANTU

- NA - NYAME AKUMA

- SAAAm - SOCIETY OF AFRICANIST ARCHAEOLOGISTS IN AMERICA

- SAAS - SOUTH AFRICAN ARCHAEOLOGICAL SOCIETY

- SAfA - SOCIETY OF AFRICANIST ARCHAEOLOGISTS

- TSAAB - THE SOUTH AFRICAN ARCHAEOLOGICAL BULLETIN

- WAC-86 - WORLD ARCHAEOLOGICAL CONGRESS - 1986 


\section{APRESENTAÇÃO}

Com esta dissertação apresentamos uma preocupação que deu origem ao nosso projeto de mestrado sobre as revistas especializadas como fontes de história da Arqueologia Africana. Trata-se de dimensionar a construção do conhecimento em Arqueologia em face dos processos históricos de descolonização do continente africano no final do século XX e que passa pela "descolonização" da própria arqueologia africana. Para tanto propomos uma análise do papel dos arqueólogos - sejam eles africanos e africanistas (nesta perspectiva, aqueles não-africanos) -, entre os anos de 1987 a 1993 tendo como fonte documental os editoriais publicados em três boletins The South African Archaeological Bulletin (TSAAB), Nyame Akuma (NA) e Nsi - Bulletin de Liaison des Archéologues du Monde Bantu.

As revistas científicas especializadas, de modo geral, foram produzidas tanto por universidades e museus quanto por sociedades científicas, sendo sobre estas e seus boletins que nos detivemos. A escolha desses três boletins justifica-se, inicialmente, pela possibilidade de entrar em contato com os posicionamentos ideológicos dos editores dos boletins na constituição da Arqueologia da África e sobre a África. Existe uma literatura consolidada sobre a análise histórica das revistas e jornais (CAPELATO e PRADO, 1980; CAPELATO, 2005; SARLO, 2005; CORACINI, 2007; DE LUCA, 2010). A partir dela nos baseamos para considerar os boletins de arqueologia como repositórios de ideias sobre o papel sociopolítico do arqueólogo. É nesse ponto que reside a problemática desses boletins cujos editoriais foram selecionados.

A escolha desses três boletins arqueológicos também é explicada pela preocupação em entender se há diversidade de ideias na constituição dos papéis ou imagens dos arqueólogos africanos e africanistas, como essas ideias aparecem nos editoriais e quais são as suas funções.

Os boletins apresentam-se como um espaço para divulgação rápida das atividades dos arqueólogos na África, dos saberes arqueológicos constituídos nas pesquisas de campo e como um veículo de interação dos arqueólogos membros das sociedades arqueológicas (South African Archaeological Society e Society of Africanist Archaeologists) e científica (Centre International des 
Civilisations Bantu). Esse é, em geral, o papel que os três boletins selecionados deveriam cumprir conforme a orientação apresentada nos primeiros editoriais dos primeiros números.

A análise sobre o papel que os boletins cumpriram de fato na construção das imagens dos arqueólogos africanos e africanistas inicia-se com o recorte cronológico entre os anos de 1987 e 1993. Os três boletins circularam concomitantemente entre o ano de 1987 até 1992. Em 1993, o boletim Nsi foi assimilado ao Nyame Akuma.

Esse é o momento histórico das guerras civis e das crises econômicas após as independências das antigas colônias da França, Bélgica, Inglaterra, Portugal e Espanha (M'BOKOLO, 2011), do crepúsculo do regime segregacionista na África do Sul (DÖPCKE, 1998), das demandas dos arqueólogos africanos, residentes no continente africano ou exilados, por espaço nas publicações arqueológicas (BAGODO, 2004). É ainda o momento dos debates escritos veiculados pelos editoriais dos boletins sobre a importância da Arqueologia Comunitária e do Patrimônio Arqueológico nos países da África subsaariana a partir das discussões da arqueologia pósprocessual em meados dos anos 1980.

O conhecimento científico e, especialmente o arqueológico, produzido na África e sobre a África é pouco conhecido (LIMB, 2005; SMART, 2005 e TEFERRA, 2004). Segundo Robertshaw (1994), isto se deve aos problemas que atingem diversas regiões africanas nas décadas de 1980 e 1990 que dificultavam a produção e a divulgação do conhecimento arqueológico, em decorrência das guerras civis que restringiam as comunicações e a distribuição de material impresso; as interrupções no abastecimento energético; e, o baixo investimento dos governos africanos em desenvolvimento científico e tecnológico devido às crises econômicas, entre outros problemas relatados. Se esse conhecimento arqueológico é pouco conhecimento, a história sobre o pensamento arqueológico e a construção das imagens dos arqueólogos africanos e africanistas requer ainda estudos.

O estudo dos três boletins disponíveis eletronicamente sobre Arqueologia da África e sobre a África proporciona uma oportunidade para 
compreender como a comunidade de arqueólogos discute, interpreta e registra as ideias recorrentes sobre os papéis dos arqueólogos africanos e africanistas, que tentamos definir adequadamente no decorrer da dissertação (capítulos um e sete), no período de consolidação dos Estados africanos independentes, entre os anos de 1987 e 1993. Assim, os boletins selecionados para estudo foram considerados enquanto fontes documentais da história do pensamento arqueológico sobre a África e sobre o que é ser arqueólogo nesse continente.

Nosso objetivo foi desenvolver uma reflexão sobre as estratégias pelas quais o objeto dos editoriais dos boletins - o arqueólogo africano e africanista foi construído em meio a uma diversidade de temas abordados pelos editores. O nosso objetivo principal foi elaborar uma interpretação de um corpus documental sobre a história do pensamento arqueológico no contexto da construção dos Estados africanos nos anos de 1987 a 1993.

Baseados na metodologia de Lyman et al. (2005), Dyson (1985) e, principalmente, Foucault (1972), constituímos um banco de dados dos editoriais, realizamos a identificação dos temas apresentados nos editoriais em palavras-chave principal e secundária e analisamos o corpus documental composto de trinta e quatro editoriais.

Em resumo, nesta dissertação pretendemos apresentar um repertório documental resultante de uma investigação sobre as imagens dos arqueólogos construídas nos editoriais e de que forma essas imagens foram veiculadas através dos três boletins, esperando que isso seja uma contribuição para os estudos de Arqueologia da África no Brasil.

\section{Estruturação do Trabalho}

A nossa dissertação foi estruturada em três partes.

Parte I - Contextualização da pesquisa. Trazemos a discussão que fundamenta a análise dos editoriais e é constituído de três capítulos. O primeiro capítulo trata da metodologia da nossa pesquisa: como se configurou o 
problema analisado, a formação do corpus documental e a composição da nossa perspectiva de análise dos trinta e quatro editoriais.

No capítulo dois desta primeira parte da dissertação tratamos da história da pesquisa arqueológica na África Central e Austral. Recorte este justificado pelo fato dessas regiões nos interessarem prioritariamente nos estudos africanos e africanistas. Nele realizamos a revisão bibliográfica sobre a trajetória da arqueologia nas regiões Central e Austral do continente. Nele também abordamos o cenário das relações sociais, políticas e econômicas entre o início do século $X X$ até o período do nosso recorte temporal. E temos nele ainda uma análise do período de 1987 a 1993 na tentativa de compreender as especificidades da pesquisa arqueológica no momento em que se configura a circulação dos boletins arqueológicos.

Através do capítulo três tratamos de definir historicamente o papel das sociedades científicas, especificamente arqueológicas, na publicação dos boletins.

Parte II - Análise dos dados. Constitui-se dos capítulos quatro a sete. No capítulo quatro examinamos os editoriais do boletim sul-africano The South African Archaeological Bulletin. No capítulo cinco, os editoriais do boletim norteamericano Nyame Akuma. No capítulo seis tratamos dos editoriais do boletim africano $N s i$, e o capítulo sete é uma tentativa de realizar uma análise comparativa dos editoriais dos três boletins arqueológicos.

Parte III - Conclusão que apresentamos as considerações finais sobre o nosso estudo.

Apresentamos ainda a seção de anexos constituída pelas tabelas das palavras-chave principais e secundárias elaboradas a partir da análise dos editoriais do nosso corpus documental; pela base de dados em meio eletrônico e pelo catálogo das fotografias constituintes desta dissertação com legendas comentadas livremente. 
PARTE I - CONTEXTUALIZAÇÃO DA PESQUISA 


\section{FUNDAMENTOS METODOLÓGICOS PARA A ANÁLISE DO CORPUS}

[...] não há saber sem uma prática discursiva definida, e toda prática discursiva pode-se definir pelo saber que ela forma. (FOUCAULT, 1972, p. 221)

\section{Sobre africanos e africanistas}

Uma das nossas primeiras questões a ser abordada será a terminologia indicada nas expressões arqueólogos africanos e africanistas ou arqueologia africana e africanista que aparecem nos editoriais selecionados para o corpus documental dessa dissertação. Para demonstrar seus usos, destacamos os seguintes trechos dos editoriais:

O ano de 1994 promete ser rico para a arqueologia africana porque terá lugar também a próxima reunião bienal da Society of Africanist Archaeologists, na Universidade de Indiana, nos Estados Unidos. (Nsi, 1992, n.10-11, p.3 - tradução livre, grifos nossos) ${ }^{1}$

Eu acho que todos nós que estamos envolvidos na formação de arqueólogos africanistas precisamos responder à reclamação de Ucko [...] (NA, 1993 dezembro, n.40, p.1 - tradução livre, grifos nossos) $)^{2}$

Os editoriais do boletim The South African Archaeological Bulletin (TSAAB) especificam ainda mais a terminologia recorrendo ao uso das expressões arqueólogos sul-africanos e arqueologia sul-africana, como podemos constatar:

Os arqueólogos sul-africanos são agora consideravelmente mais conscientes sobre, e receptivos para, suas responsabilidades para com a sociedade como um todo do que eles foram há uma década. (TSAAB, 1991 dezembro, vol.46, n.154, p.59 - tradução livre, grifos nossos) $)^{3}$

\footnotetext{
${ }^{1}$ Cette année 1994 s'annonce riche pour l'archéologie africaine car se déroulera aussi la prochaine réunion biennale de la Society of Africanist Archaeologists à l'Université d'Indiana aux États-Unis. (Nsi, 1992, n.10-11, p.3)

${ }^{2}$ I think all of us who are involved in training Africanist archaeologists need to respond to Ucko's complaint [...] (NA, n.40, dezembro 1993, p. 1)

${ }^{3}$ South African archaeologists are now considerably more conscious of, and receptive to, their responsibilities to society as a whole than they were a decade ago. (TSAAB, vol.46, n.154, dezembro 1991, p.59)
} 
Essa categorização poderia considerar o local do nascimento. No entanto, esse aspecto não é determinante do tipo de posicionamento ideológico do arqueólogo. Segundo Bagodo (2004, p.441), o emprego das expressões arqueólogos africanos e africanistas para os especialistas que se ocupam da África subsaariana explica-se em razão da corrente de pensamento que eles estão inseridos. É o que podemos denotar da categorização de De Medeiros apud Bagodo (2004, p. 444) sobre os arqueólogos africanistas:

i) Especialistas em África considerados como referência no Ocidente;

ii) Porta-vozes da África no Ocidente, ao se identificar com os africanos, tornam-se exóticos dentro da sua própria cultura;

Da Conferência de Berlim (1884-1885) até o final da Segunda Guerra Mundial, a pesquisa arqueológica no continente africano foi quase totalmente realizada por arqueólogos amadores e profissionais oriundos das metrópoles. Nesse contexto, o termo africanista surgiu por volta do ano 1910 para designar o pesquisador ocidental especialista em línguas e civilizações africanas (BAGODO, 2004, p.443). Dessa perspectiva, os africanistas estabeleceram a pesquisa arqueológica originalmente vinculada aos interesses metropolitanos de exploração e apropriação científica das colônias africanas. Essa arqueologia pode ser considerada como uma variante das práticas colonialistas. Podemos citar como um exemplo disso, a formação da coleção arqueológica do Museu do Dundu em Angola, fundado pela Companhia de Diamantes de Angola (Diamang) em 1937 (AREIA, 2007).

Após as independências e durante a construção dos Estados nacionais africanos houve a continuidade das práticas coloniais na pesquisa arqueológica da África subsaariana com a dominação de pequenos grupos de pesquisadores africanistas sobre os meios de publicação científica (SCHMIDT, 2009; BAGODO, 2004; SHEPPERD, 2002; TRIGGER, 1984).

A categorização de Bagodo (2004, p.446-7) contempla a arqueologia africana, a afro-endógena, na qual o pesquisador africano, entre as décadas 1970 e 1990, assume a função de condutor de estudos na perspectiva de uma arqueologia plural e rica em variantes sub-regionais, nacionais e locais. Em 
relação à metodologia, o arqueólogo africano volta-se para a dinâmica interna dos contextos locais, regionais ou continentais da África. Nessa classificação, que ressalta os fatores internos dos contextos arqueológicos, Bagodo (2004) cita os volumes de um a três, da obra História Geral da África, editada pela UNESCO, como um modelo desse tipo de arqueologia africana em contraposição a uma arqueologia exógena ou africanista, nas palavras do autor.

A nossa análise do corpus documental considerou ao delimitar as diferenças entre os arqueólogos africanos e africanistas, o contexto de utilização da terminologia indicada nos editoriais. Essa nomenclatura, especificada nas três citações anteriores, apresenta variantes de usos e dos papéis atribuídos aos arqueólogos africanistas e africanos, entre os anos 1987 e 1993.

\section{A constituição do corpus documental}

O acesso às fontes documentais, no Brasil, sobre a História da Arqueologia da África e sobre a África, especialmente das regiões central e austral, é um trabalho instigante e árduo. Poucos estudos foram produzidos sobre esse tema em nosso país. No exterior, esses foram publicados em francês e em inglês: ROBERTSHAW, 1990; TRIGGER, 1990; DE MARET, 1990; CORNEVIN, 1998; SHEPPERD, 2000, 2002 e 2003; MITCHELL, 2002; BAGODO, 2004; e, PHILLIPSON, 2005. A história intelectual da arqueologia dessas regiões é um tema importante, pois se liga diretamente à construção do conhecimento arqueológico sobre a África subsaariana, como destacado na discussão terminológica. Quando nos atentamos para as formas de divulgação desse conhecimento arqueológico, percebemos que menos sabemos sobre esse assunto.

Assim, constituir o corpus documental, a metodologia de análise das fontes sobre a temática e apresentar os resultados dessa pesquisa constituem o cerne da nossa dissertação.

Na primeira fase da pesquisa, procuramos as fontes documentais sobre a arqueologia africana e africanista, nos termos que foram postos, como: 
publicações periódicas especializadas em cultura material africana, além da publicação African Archaeological Review previamente selecionada no projeto de mestrado. Esse itinerário de constituição do conjunto documental sobre a história do pensamento arqueológico implicou em três fases de seleção, tendo se iniciado com o levantamento dos artigos e dos editoriais publicados em cinco revistas: African Archaeological Review, já mencionada, The South African Archaeological Bulletin, African Arts, Journal des Africanistes e The Journal of African History. Os fatores que levaram à escolha dessas publicações no nosso levantamento inicial foram:

a) o reconhecimento internacional da importância destas revistas na disseminação de estudos sobre cultura material africana e de outras problemáticas pertinentes à arqueologia;

b) a presença de artigos diversos sobre a África Central, região pouco abordada nos estudos de cultura material;

c) a presença de artigos sobre cerâmica de diferentes regiões da África que foi um tema precedente a toda a pesquisa;

Esse levantamento inicial, no entanto, nos colocou diante de um problema: como analisar um corpus documental oriundo de revistas sobre cultura material africana, arqueologia da África, de modo geral, com tamanha abrangência? Esta abrangência, na verdade, espelha a diversidade de diferentes regiões geográficas analisadas pelos diversos enfoques da Arqueologia, das Artes e da História. Seria necessário então restringir esse alcance, o que nos levou a nos debruçar sobre duas seções das revistas:

1‥ O editorial; $\mathrm{e}$,

2a . A seção relativa aos artigos de pesquisas originais sobre cultura material da África Central e Austral e sua cerâmica.

$\mathrm{Na}$ segunda fase da pesquisa documental, mantivemos o recorte temporal proposto no projeto de mestrado, além de restringir nosso levantamento de dados em apenas três das cinco publicações antes aventadas. Selecionamos os editoriais e os artigos de análise disponíveis pelo 
acesso eletrônico VPN-USP ou pelas bibliotecas da universidade referentes à África Central e Austral e sua cerâmica, publicados entre 1983 e 2010, nas revistas African Archaeological Review, African Arts e The South African Archaeological Bulletin.

Cabe salientar que a definição desse recorte temporal se deu pela oportunidade de se debruçar por um período pouco estudado na história da arqueologia da África. Todavia, houve a necessidade de uma terceira fase de seleção.

Diante da ampla massa documental gerada e das sugestões da banca de qualificação para permitir uma análise qualitativa do material mais aprofundada e profícua, fizemos uma revisão nos critérios de seleção das fontes e no recorte temporal.

Essa revisão levou a uma redução significativa no tamanho do corpus documental - de 212 editoriais e artigos para 34 editoriais. Dessa forma, focamos nos editoriais publicados nos boletins The South African Archaeological Bulletin, que a partir desse momento será designado pelas letras iniciais "TSAAB", o qual já foi relacionado nas seleções documentais anteriores, Nyame Akuma - Bulletin of the Society of Africanist Archaeologists, daqui em diante nomeado pela sigla "NA" e Nsi - Bulletin de Liaison des Archéologues du Monde Bantu, representado agora por "Nsi". Esses dois últimos incorporados nessa terceira fase de seleção.

O recorte temporal compreende os anos de 1987 a 1993, um período que abarca a circulação simultânea desses três boletins (1987-1992), além da incorporação do Nsi pelo NA no ano de 1993. Também houve o investimento privado na "Arqueologia de Contrato", a emergência da "Arqueologia Comunitária" e das políticas de Gestão Patrimonial, o fomento dos estudos arqueológicos pelos políticos africanos e o envolvimento dos arqueólogos sulafricanos na polêmica em torno do boicote ao regime segregacionista da África do Sul. Consideramos o estudo desse período como de fundamental importância para compreender os papéis dos arqueólogos africanos e africanistas no período de consolidação dos países africanos recémindependentes. 
Os critérios da definição desse corpus documental foram:

a. Possibilidade de acesso eletrônico e gratuito aos boletins selecionados como usuária VPN-USP;

b. A existência de editoriais nos boletins arqueológicos e serem esses boletins vinculados às sociedades arqueológicas, como: South African Archaeological Society - daqui em diante nomeada "SAAS" e Society of Africanist Archaeologists - a partir daqui denominada "SAfA" ou a científica Centre International des Civilisations Bantu representada agora pela sigla "CICIBA".

Outro fator determinante foi à denominação "boletim" das publicações selecionadas que têm como principais características a agilidade tanto na produção editorial e quanto na publicação, a periodicidade e o público receptor bem direcionado, o arqueólogo, semelhança dos artigos e dos relatórios dos trabalhos de campo.

Quanto à agilidade da produção do boletim, destacamos o trecho do editorial da NA, assinado por John Bower, de dezembro de 1992, para elucidar a nossa definição de "boletim" a qual está presente na fonte:

Dada a missão de Nyame Akuma para publicar prontamente relatórios de trabalhos em curso, parece inadequado se envolver em longas comunicações entre autor-editor sobre erros pequenos [... $]^{4}$ (NA, 1992 dezembro, n.38, p.1 - tradução livre, grifos nossos)

Em outro exemplo, o trecho do editorial da Nsi de 1992 apresenta o tipo de autor, o arqueólogo, e de texto que o boletim procura publicar para seus leitores que também são arqueólogos:

Em 1991 eu reclamei primeiro da falta de arqueólogos correspondentes que trabalham na região [...] $\mathrm{O}$ primeiro ponto depende somente de VOCÊS [...]5 (Nsi, 1992, n.10-11, p. 3 tradução livre, grifos nossos)

\footnotetext{
${ }^{4}$ Given Nyame Akuma's mission to publish timely reports of ongoing work, it seems inappropriate to engage in extended author-editor communications about minor errors [...] (NA, 1992 dezembro, n.38, p.1)

${ }^{5}$ En 1991 j'avais déploré $1^{\circ}$ ) le manque de répondants des archéologues en poste dans la région [...] Le premier point ne dépend que de VOUS [...] (Nsi, 1992, n.10-11, p. 3)
} 
A justificativa para ter escolhido os editoriais como fontes documentais para investigar os papéis dos arqueólogos africanos e africanistas é que, a priori, consideramos que eles apresentavam a posição das sociedades SAAS, SAfA e CICIBA diante de um tema ou de um fato relevante na trajetória da pesquisa arqueológica africana e africanista. Essa posição seria comunicada no texto do editor do boletim. Assim supomos.

\section{Referenciais teóricos}

Realizamos a pesquisa dos estudos específicos sobre editoriais e identificamos os trabalhos de Bedin (2003) e Lopes (2002), ambos direcionados para os editoriais dos jornais paulistas de grande circulação. Bedin (2003) ao definir a função dos editoriais cita Rabaça e Barbosa, autores do Dicionário de Comunicação, editado em 1987. Para eles, [o editorial] define e expressa o ponto de vista do veículo ou da empresa responsável pela publicação (do jornal, revista etc.). (Rabaça e Barbosa apud BEDIN [2003, p.53]). Segundo Bedin (2003), para cumprir essa função, o editorial seria produzido, sem assinatura individual, com recursos persuasivos e requisitos estilísticos próprios. Esse gênero textual, para o autor, manifesta a tomada de posição do jornal ou da revista sobre um fato entre outras opiniões diversas. Sua análise, portanto, consideraria a estratégia ideológica planejada por uma fração das elites de poder em um dado período, presente de forma implícita ou explícita na fonte (BEDIN, 2003, p.60).

Lopes (2002, p.64), por sua vez, define a natureza do editorial como um texto de sanção, de reafirmação de valores e de interpretações veiculados pelo editor. Nessa perspectiva, os atores sociais citados ao longo da sua escritura são transfigurados em temas do repertório do fazer interpretativo do jornal ou da revista.

Sendo objeto de apreciação de Bedin (2003) e Lopes (2002), as propostas dos editoriais dos jornais de grande circulação para o público médio - análise realizada sob orientação que homogeneíza os temas ali tratados não é suficiente para compreender a natureza de um corpus como o nosso. 
Afinal, esse é constituído de trinta e quatro editoriais de três boletins de sociedades arqueológicas africanas e africanistas que versam sobre temas diversos e apresentam as assinaturas dos editores.

Pesquisamos, ainda, estudos específicos sobre as revistas especializadas de arqueologia e identificamos os trabalhos de Dyson (1985) e Lyman et al. (2005). Dyson (1985, p.452), ao realizar a análise comparativa de duas revistas norte-americanas, American Antiquity e American Journal of Archaeology, afirma que a maioria das revistas científicas são espelhos da história intelectual da disciplina que elas representam. ${ }^{6}$ Para entender os últimos cinquenta anos dessa história intelectual da arqueologia americana, o estudioso constituiu um corpus documental de artigos publicados entre os anos de 1935 a 1984. O autor não forneceu o número total de artigos analisados, mas identificou vinte temas, dos quais selecionou os cinco mais recorrentes para examinar como eles eram abordados nas duas revistas. Nessa análise, se concentrou nas afiliações acadêmicas e, por fim, na história da linha editorial de ambas as revistas. Dyson (1985) apontou para o fato de que cada uma delas desenvolveu papéis importantes na difusão das pesquisas arqueológicas sobre a Antiguidade Clássica e a Arqueologia Americana, nas inovações e nos continuísmos da interpretação do registro arqueológico. Tais continuísmos, para ele, poderiam estar relacionados à dominância dos grupos de pesquisadores que publicam e dos grupos de editores das revistas.

Lyman et al. (2005) analisaram a taxa de publicação dos artigos de arqueologia nas revistas científicas Science e Scientific American. A hipótese testada referia-se a uma ideia de que depois do ano de 1965, houve um aumento da publicação dos artigos de Arqueologia nessas revistas científicas devido ao "programa" dos arqueólogos processualistas que visava tornar a disciplina mais "científica". Esses autores mencionam que, para essa análise, constituíram uma base de dados composta de 636 artigos publicados entre os anos de 1940 a 2003, que inclui o nome dos autores, o ano da publicação, o volume e o número da publicação, e o número das páginas dos artigos. 0 acesso a esse corpus é restrito e uma cópia dele pode ser obtida junto aos

\footnotetext{
${ }^{6}$ Major journals are mirrors of the intellectual history of the disciplines that they represent. (DYSON, 1985, p.452)
} 
estudiosos (LYMAN ET AL., 2005, p.158). Entretanto, não chegamos a ter acesso a ela até a conclusão dessa dissertação.

Lyman et al. (2005) justificam esse longo período analisado. Intentavam observar as tendências dos estudos arqueológicos e a emergência da Arqueologia Processualista (LYMAN ET AL., 2005, p.158). Os autores focaram na tabulação dos dados estatísticos da base, investigaram o processo editorial e os papéis dos editores das revistas. Concluíram que ocorreu um aumento da taxa de publicação dos artigos de Arqueologia depois de 1955 e não depois de 1965, como havia sido aventado. Vale destacar que esses dois artigos de 1985 e 2005 foram publicados na revista American Antiquity em um período de vinte anos.

Ressaltamos que sob a luz da metodologia empregada no estudo de Lyman et al. (2005), formamos a base de dados do nosso corpus documental, a qual compõe-se do nome do editor, do título do editorial, do volume e do número da publicação, do seu endereço eletrônico, do ano e do mês da publicação, de um resumo, das palavras-chave principal e secundária e de meus pareceres sobre o editorial. Destacamos que a base de dados foi concebida como uma ferramenta de organização e sistematização das informações dos editoriais selecionados. Para fins de apreciação, ela encontrase em meio eletrônico na seção de anexos.

Nessa base de dados identificamos e agrupamos os editoriais inspirados também na metodologia de Dyson (1985), de acordo com os temas abordados. Estes foram por nós designados por palavras-chave principal e secundária, conforme a relevância da temática abordada que se manifestou pela quantidade de parágrafos destinados ao assunto, como podemos observar no quadro: 


\begin{tabular}{|l|l|}
\hline \multicolumn{1}{|c|}{ Palavras-chave principais } & \multicolumn{1}{|c|}{ Palavras-chave secundárias } \\
\hline 1. Agradecimentos e & 1. Arqueologia Comunitária \\
& 2. Assinaturas \\
2. Sociedade Científica & 3. Congresso \\
& 4. Ética \\
3. Organização do Boletim & 5. Informatização \\
4. Educação & 6. Lançamento \\
7. Legislação \\
5. Gestão Patrimonial & 8. Obituário \\
& 9. Patrimônio Arqueológico \\
& 10. Roubo \\
\hline
\end{tabular}

As palavras-chave principais referem-se à temática básica do editorial: "Agradecimentos e homenagens" englobam os editoriais que festejam os membros das sociedades científicas e os colaboradores do boletim; "Sociedade Científica" reúne as edições específicas da organização e das normas dessas instituições, especificamente as arqueológicas; "Organização do Boletim" concentra os exemplares designadores das regras para a publicação, seu fluxo editorial e a sua definição das coberturas temáticas, temporais e geográficas; "Educação" junta os editoriais que tratam da formação e treinamento dos arqueólogos e da instrução dos leigos em relação aos cuidados com 0 patrimônio arqueológico; e, "Gestão Patrimonial" agrupa os que divulgam as ideias e as práticas atribuídas aos arqueólogos, às comunidades e aos governos em relação ao patrimônio arqueológico.

As palavras-chave secundárias aludem ao tema que complementa a palavra-chave principal e, também, direcionam ao segundo assunto, que pode ou não estar relacionado com a palavra-chave principal: "Arqueologia Comunitária" concentra os editoriais que priorizam o protagonismo das populações nativas nos projetos arqueológicos; "Assinaturas" agrega edições expositoras das regras e condições de distribuição e recebimento dos boletins como valores, meio de transporte e cronograma; "Congresso" agrupa aqueles que disponibilizam as pautas das reuniões das sociedades científicas e de outras instituições, além de convocar os arqueólogos para os eventos da disciplina; "Ética" refere-se ao conjunto daqueles que especificam a função social dos arqueólogos e a sua relação com a comunidade nativa; 
"Informatização" congrega os que tratam das mudanças do fluxo editorial e dos layouts dos boletins com a adoção das novas tecnologias computacionais; "Lançamento" prioriza os editoriais que abordam as características da publicação lançada, além de focalizar o lançamento de outras revistas científicas especializadas em África, as quais apresentam os novos editores dos boletins. "Legislação" reúne os editoriais que informam sobre os projetos e a aprovação de leis pelos governos e sobre a proteção do patrimônio arqueológico; "Obituário" concentra os exemplares reverenciadores dos membros das sociedades científicas e colaboradores dos boletins pelos serviços prestados. "Patrimônio Arqueológico" agrupa os tratantes das especificidades dos artefatos e dos sítios arqueológicos. E, por fim, a palavrachave secundária "Roubo" condiz aos que tratam da remoção e do comércio ilícito de artefatos dos sítios arqueológicos.

A análise quantitativa dos trinta e quatro editoriais do corpus documental gerou os seguintes gráficos:

\section{Gráfico 1 - TSAAB - palavras-chave principais entre os 14 editoriais}

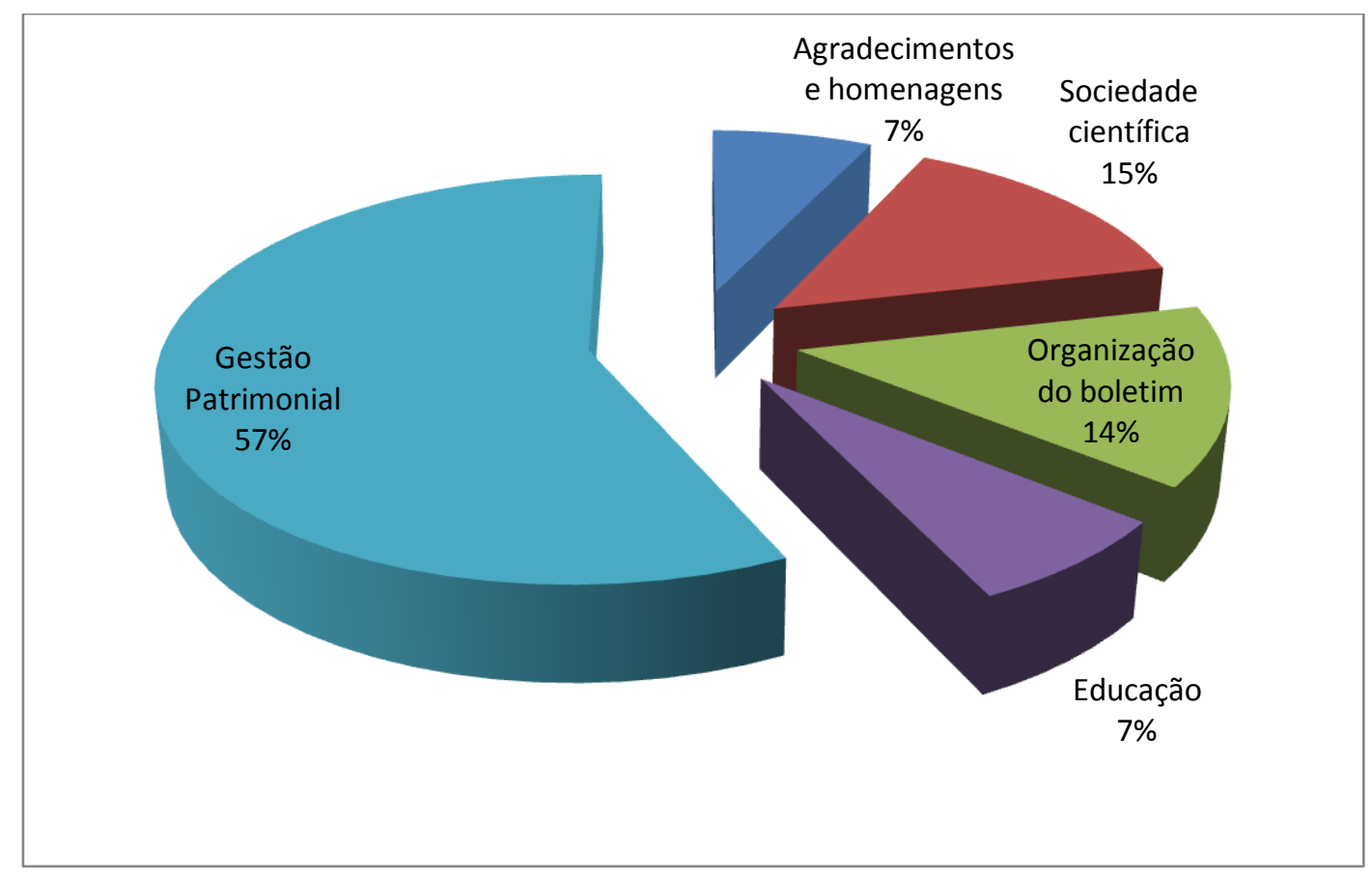

Para conhecer precisamente os detalhes sobre os dados das palavraschave principais dos 14 editoriais do TSAAB, veja a tabela sobre os números dos editoriais em relação às palavras-chave principais na seção de anexos. 


\section{Gráfico 2 - TSAAB - palavras-chave secundárias entre os 14 editoriais}

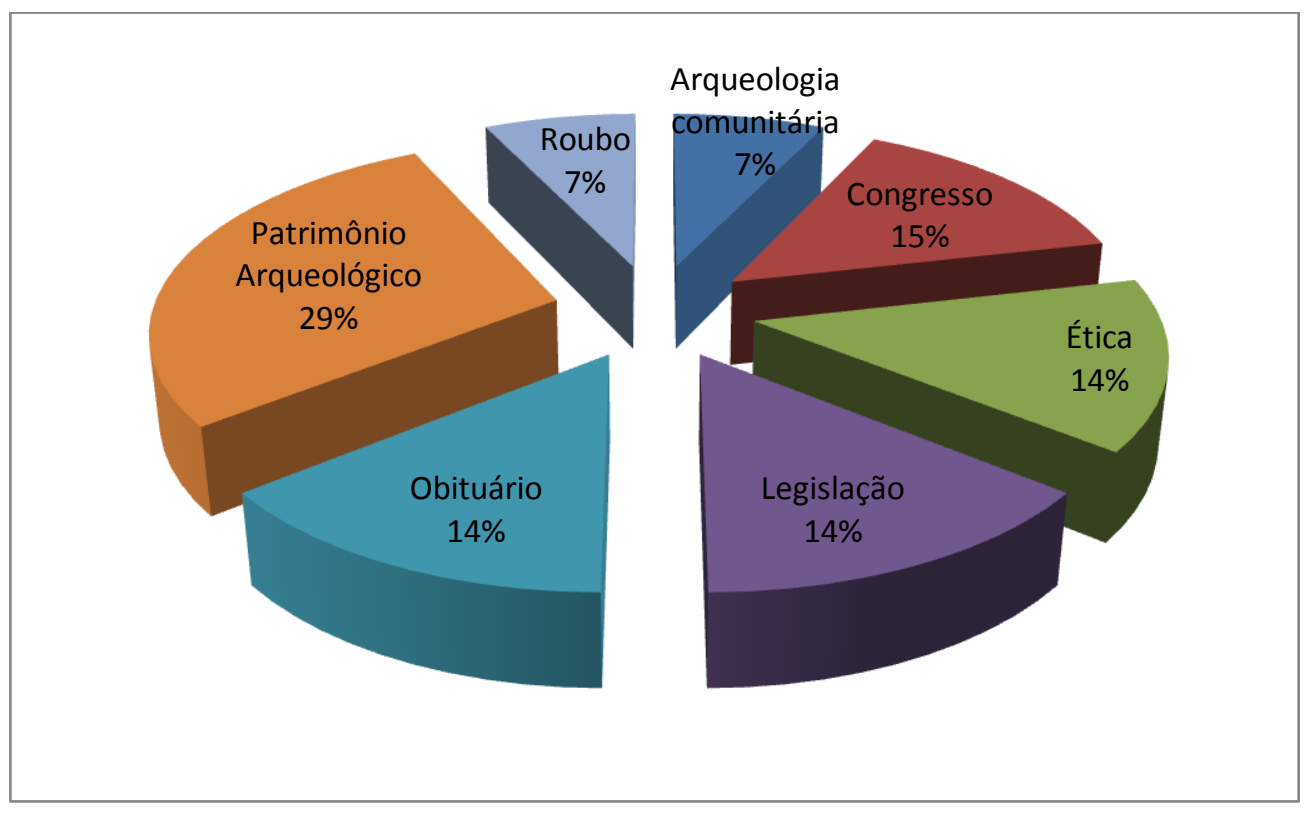

Para saber detalhadamente sobre os dados das palavras-chave secundárias dos 14 editoriais do TSAAB, veja a tabela sobre os números dos editoriais em relação às palavras-chave secundárias na seção de anexos

\section{Gráfico 3 - NA - palavras-chave principais entre os 13 editoriais}

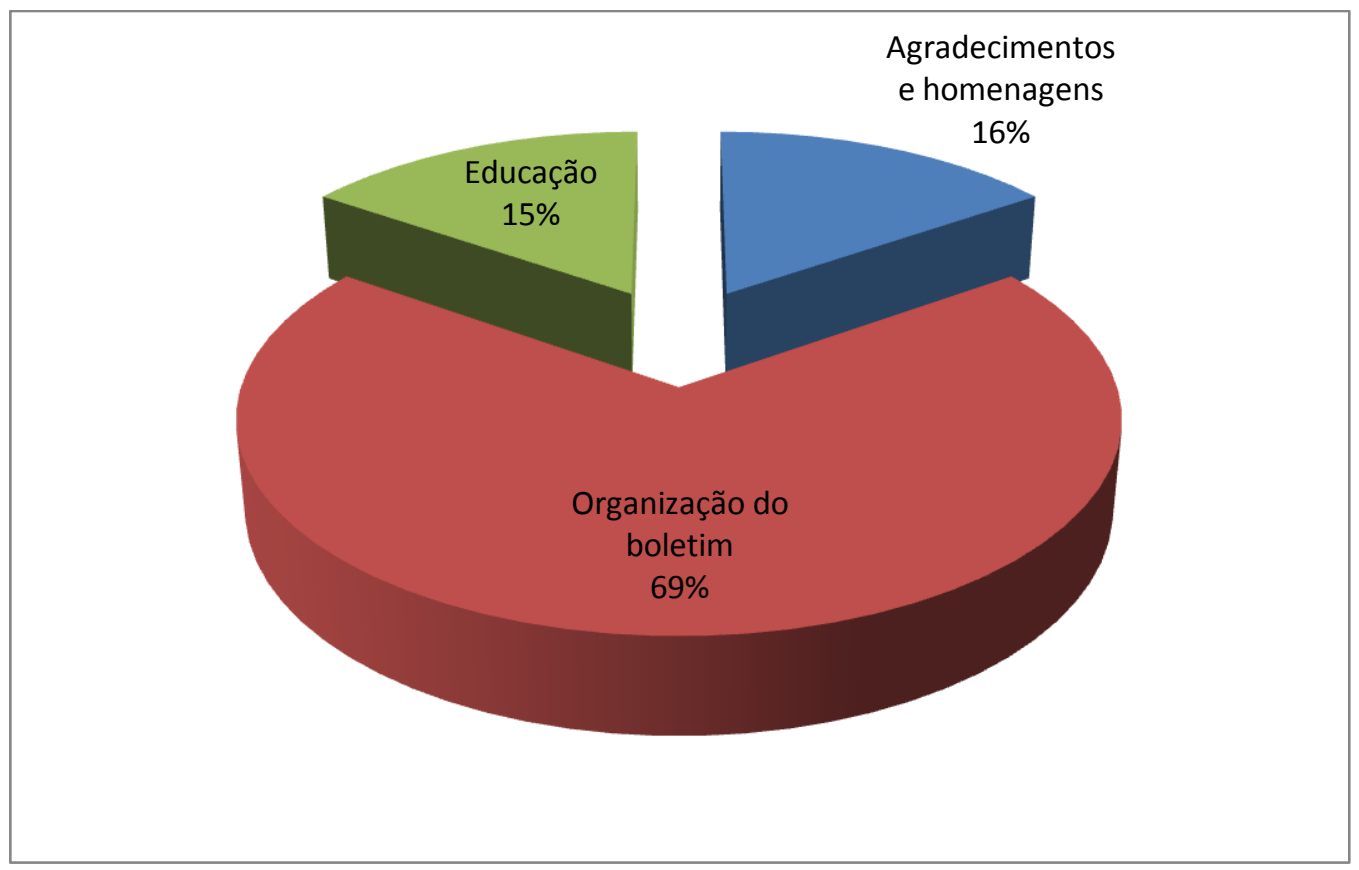

Para avaliar acuradamente os detalhes sobre os dados das palavraschave principais dos 13 editoriais do NA, veja a tabela na seção de anexos. 


\section{Gráfico 4 - NA - palavras-chave secundárias entre os 13 editoriais}

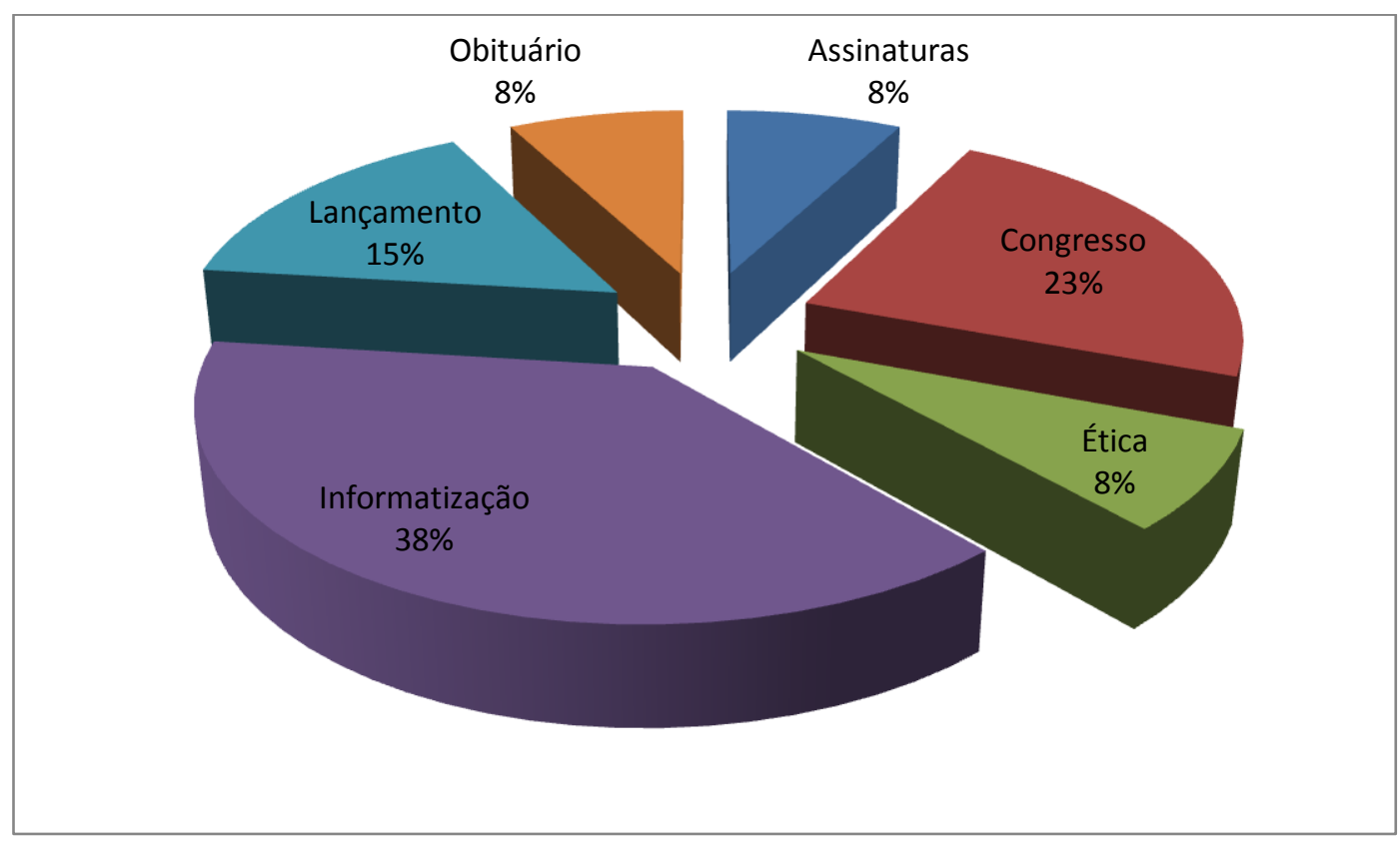

Para apreciar mais os detalhes sobre os dados das palavras-chave secundárias dos 13 editoriais do NA, veja a tabela na seção de anexos.

\section{Gráfico 5 - NSI - palavras-chave principais entre os sete editoriais}

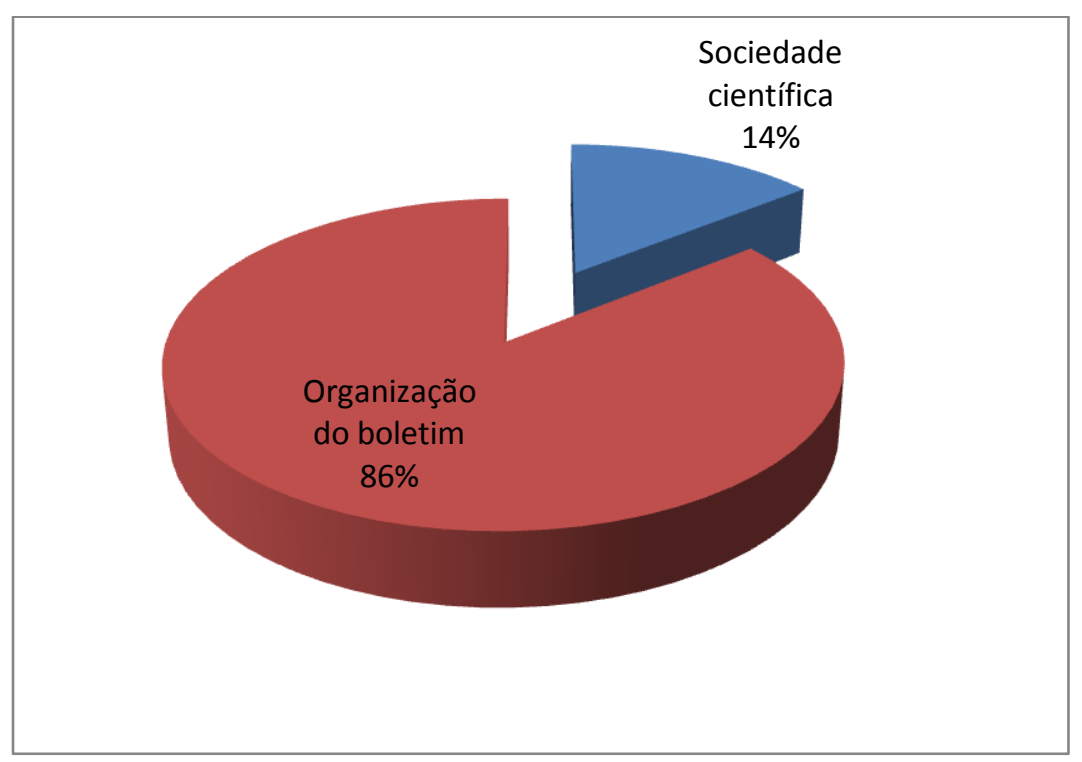

Para averiguar os detalhes sobre os dados das palavras-chave principais dos sete editoriais do Nsi, veja a tabela na seção de anexos. 


\section{Gráfico 6 - NSI - palavras-chave secundárias entre os sete editoriais}

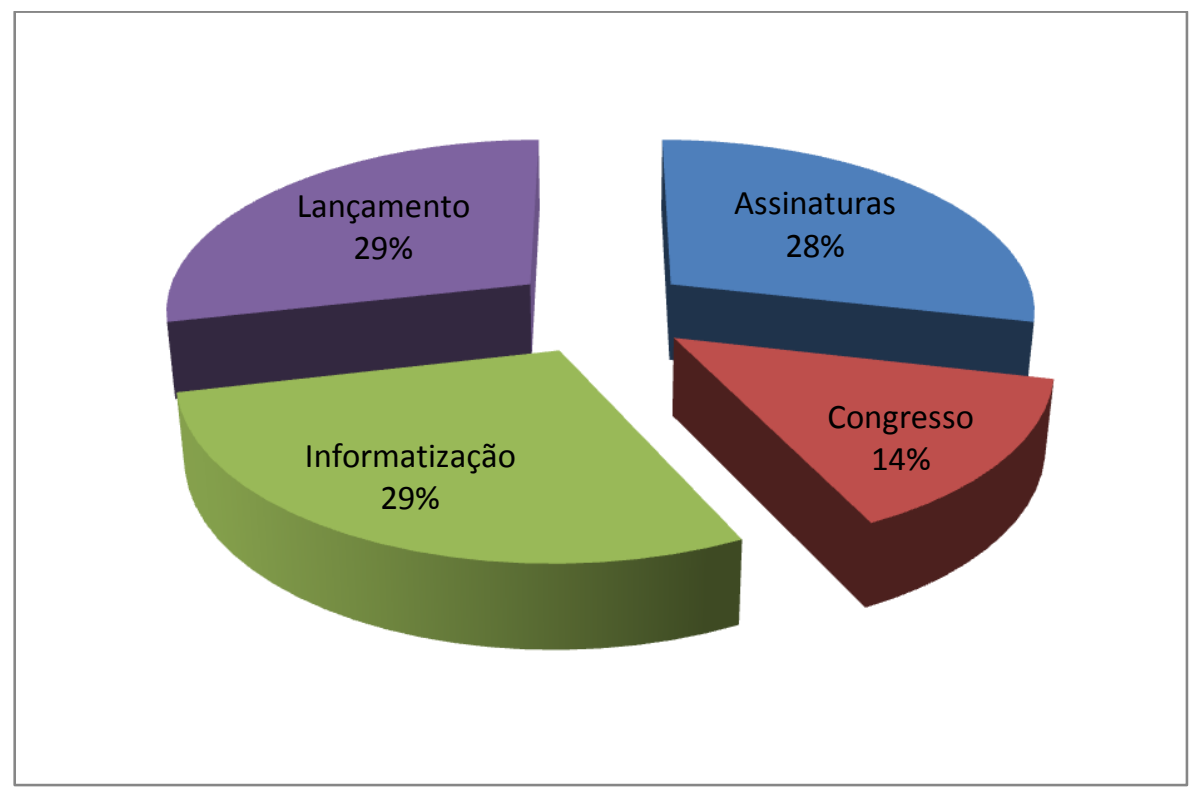

Para analisar mais os detalhes sobre os dados das palavras-chave secundárias dos sete editoriais do Nsi, veja a tabela na seção de anexos.

A análise comparativa da recorrência dos temas indicados pelas palavras-chave principais e secundárias possibilitou a confecção dos gráficos:

Gráfico 7 - Comparação das palavras-chave principais entre os editoriais da TSAAB, NA e NSI

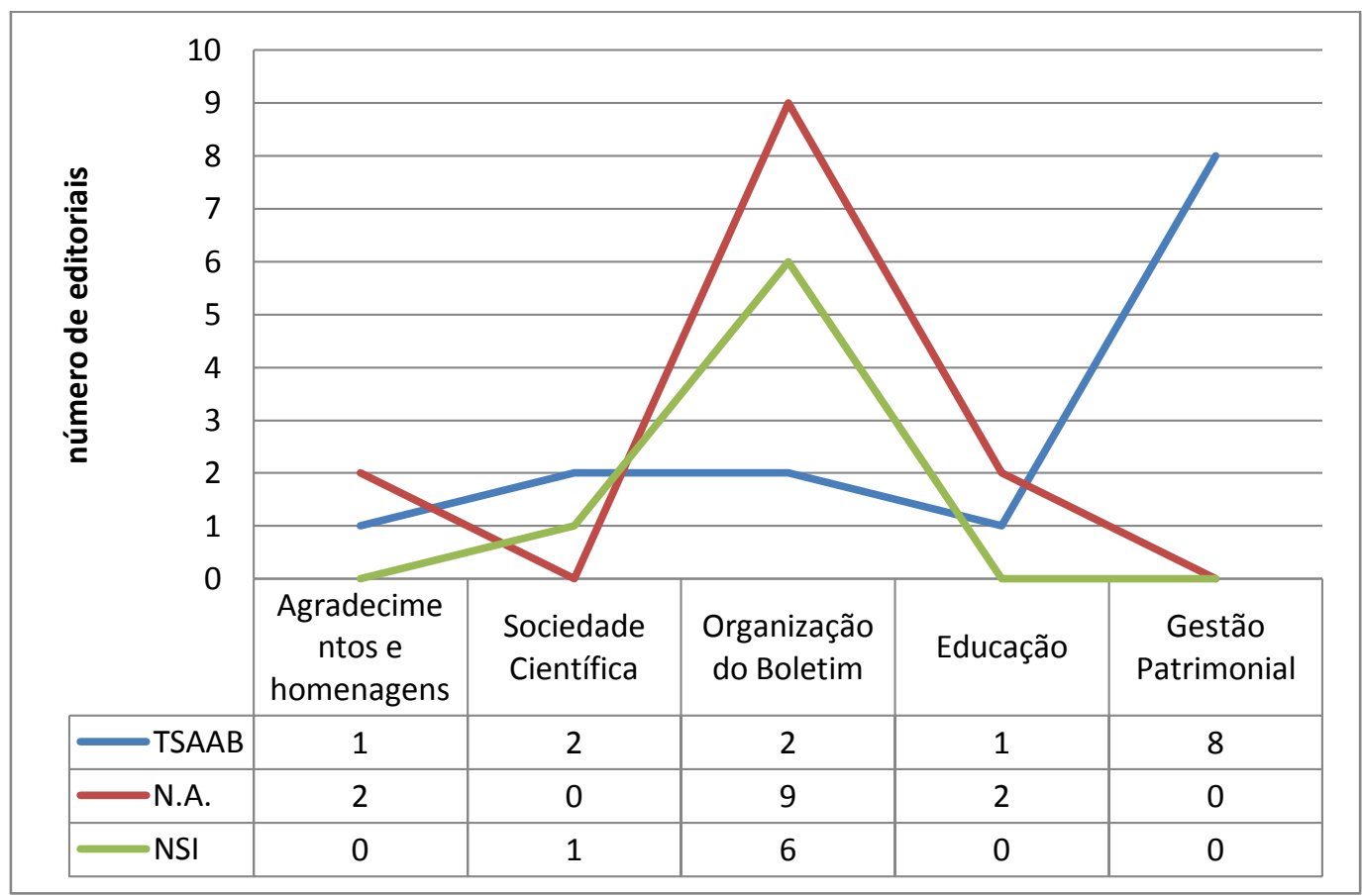


Gráfico 8 - Comparação das palavras-chave secundárias entre os editoriais da TSAAB, NA e NSI

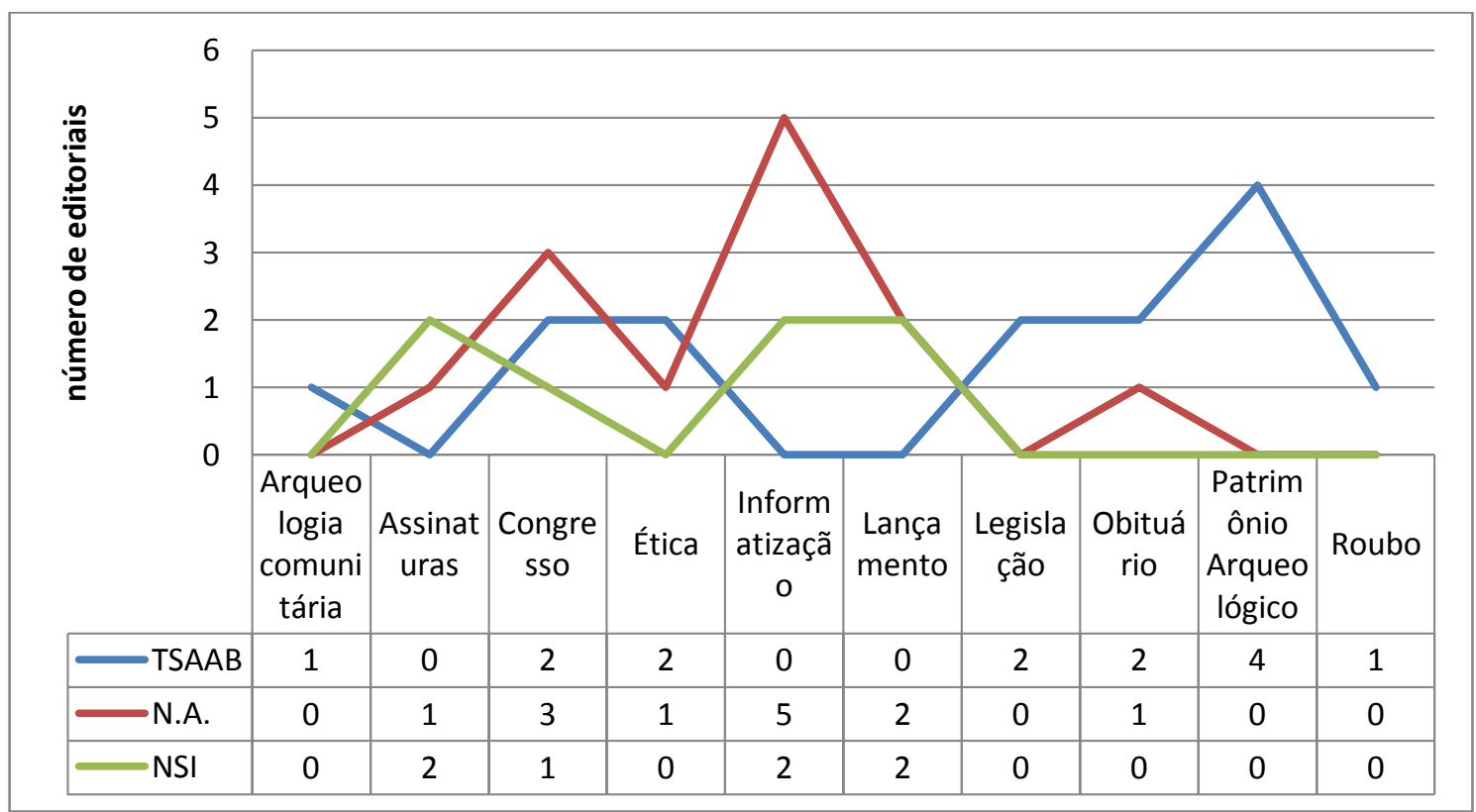

Gráfico 9 - Totalização das palavras-chave principais nos 34 editoriais

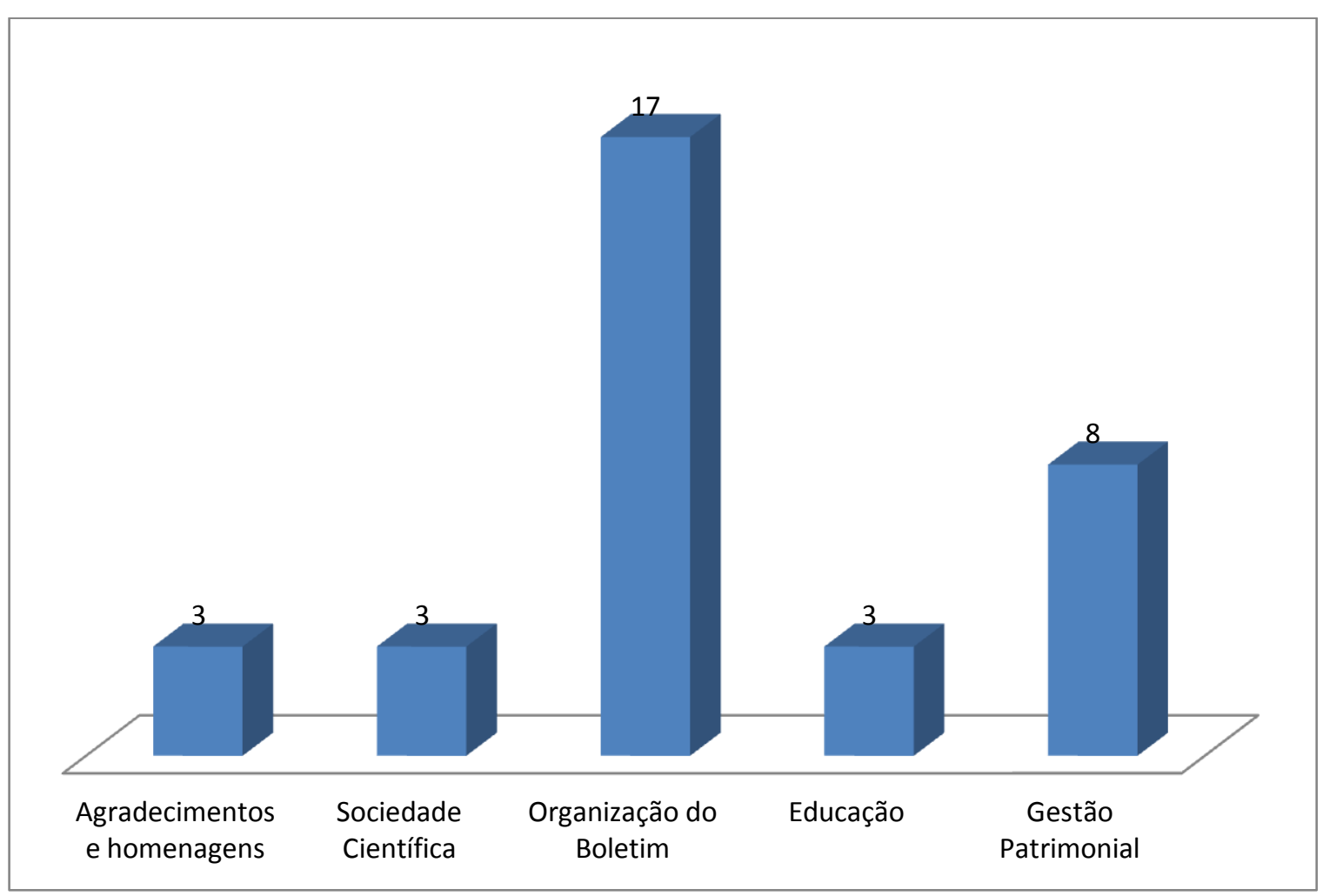




\section{Gráfico 10 - Totalização das palavras-chave secundárias nos 34 editoriais}

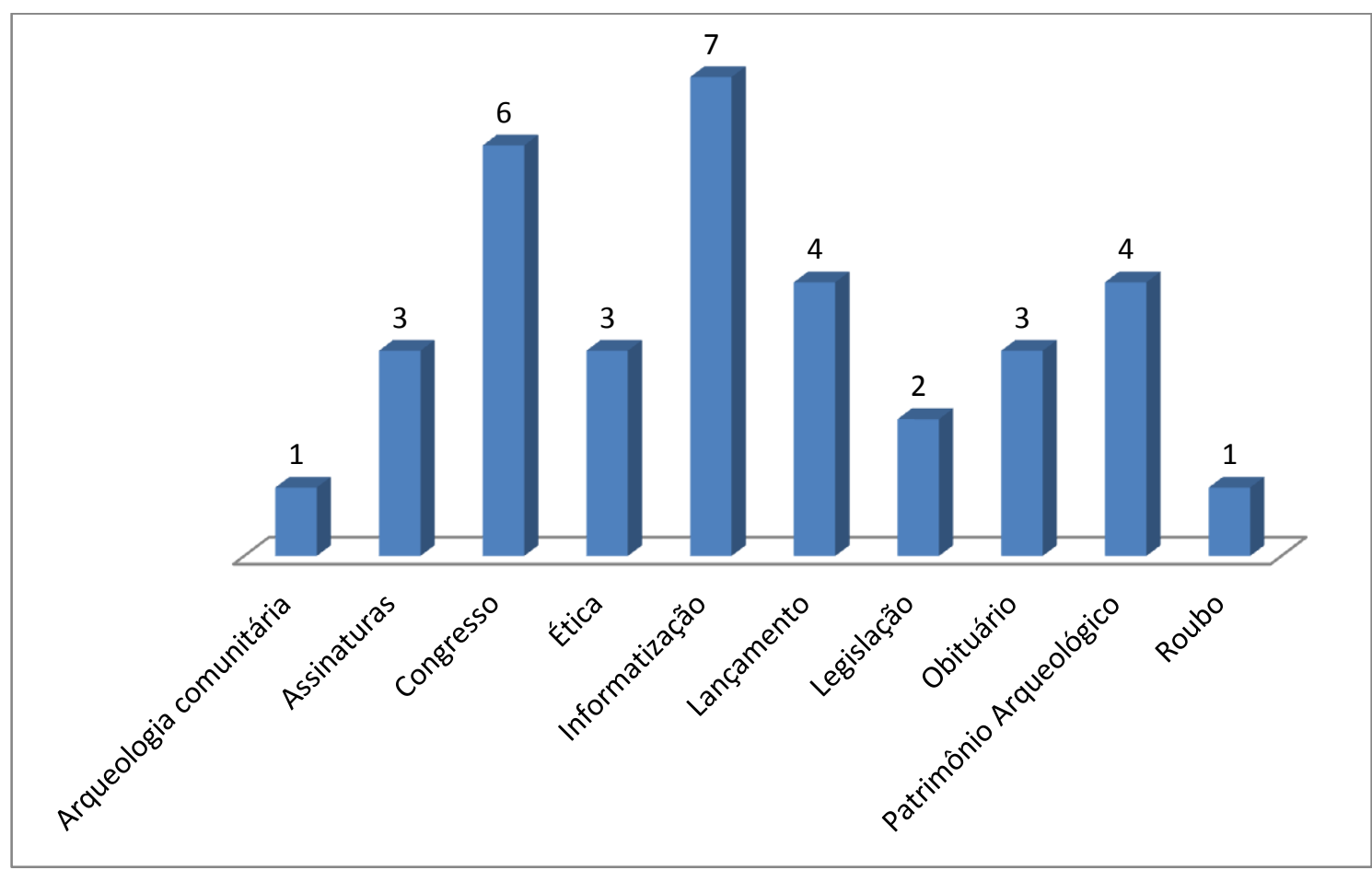

Comparando os dados do corpus documental verificamos que as palavras-chave principais "organização do boletim", identificada em 17 editoriais e "gestão patrimonial", identificado em oito editorais, são mais recorrentes.

Ao analisar sob a perspectiva quantitativa o conjunto documental, categorizando-o pelas palavras-chave principais organização do boletim e gestão patrimonial, nós poderíamos interpretar que o conteúdo do corpus estaria centrado no processo editorial, circunscrevendo as novas atribuições dos arqueólogos quanto à gestão e educação patrimonial e à formação dos futuros arqueólogos membros das sociedades científicas (CICIBA, SAAS e SAfA), estas últimas especificamente de arqueologia. Nesse sentido, a análise quantitativa restringiria apenas à determinação de uma homogeneidade temática ou, como diz Foucault (1972), uma unidade discursiva, entre os editoriais dos três boletins arqueológicos TSAAB, NA e Nsi no período de 1987 e 1993. Essa inferência se baseia no que desenvolveremos a seguir.

Ao longo do nosso estudo, baseados nas leituras de Sarlo (2005), Said (2005), Bobbio (1997), Hodder (1989) e, principalmente, Foucault (1972), 
consideramos que os editoriais são textos que, além de apresentarem aos leitores arqueólogos a organização do boletim e a preocupação com a gestão patrimonial, veiculam implicitamente os papéis ideais dos arqueólogos africanos e africanistas, segundo os padrões das sociedades SAAS, SAfA e CICIBA.

Nesse sentido, os editoriais representam, na verdade, os discursos normativos, descritivos e prescritivos sobre os arqueólogos, ou seja, ditariam o que eles deveriam ser e fazer; o que são e fazem e o que não deveriam ser e fazer (BOBBIO, 1997; SARLO, 2005; SAID, 2005). Esses textos não formam uma unidade discursiva como aparentam em vista da recorrência constatada das palavras-chave principais. Apresentam uma dispersão de temas e abordagens sobre o que é ser arqueólogo africano e africanista, como aparece no levantamento das palavras-chave secundárias. Diante disso ainda não é suficiente apenas a aplicação da metodologia de Dyson (1985) e Lyman et al. (2005), é preciso trazer outras reflexões.

Nesse sentido citamos o texto de Machado (1981) sobre o método de Foucault:

\begin{abstract}
Um tema pode se encontrar em dois tipos diferentes de discurso, do mesmo modo que um único discurso pode produzir temas diferentes. [...] Os discursos, portanto, não têm princípios de unidade. E daí surge à ideia de analisá-los como pura dispersão. A dita unidade de um discurso, como uma ciência, por exemplo, unidade esta procurada ao nível do objeto, do tipo de enunciação, dos conceitos básicos e dos temas, é na realidade uma dispersão de elementos. (MACHADO, 1981, p.162)
\end{abstract}

Considerando essa reflexão, trazemos uma preocupação quanto ao método para a análise do nosso corpus documental. Nos trechos abaixo da TSAAB, datados de junho de 1987, a editora Janette Deacon trata dos seguintes temas dispersos:

Trecho um:

A Sociedade [SAAS], em cooperação com a Southern African Society for Quaternary Research, tem financiado a impressão dos folhetos informativos em inglês e em africâner para divulgar a situação difícil da nossa arte rupestre. Nós precisamos da cooperação de todos os membros da Sociedade para garantir que as informações no folheto 
sejam mais amplamente divulgadas quanto for possível. (TSAAB, junho 1987, vol. 42, n. 145, p. 3 - tradução livre, grifos nossos) ${ }^{7}$

Trecho dois:

Podemos estender saudação (alguma dessa tardia) para vários expresidentes da South African Archaeological Society sobre os seus aniversários de 80 anos: Cran Cooke, Gerhard Fock, Keith Robinson e Eduard van Zinderen Bakker, e para Desmond Clark e Rudner Jalmar nos seus aniversários de 70 anos. $O$ fato de que nós não podemos realmente chamar nenhum de 'aposentado', pois todos continuam a publicar resultados de pesquisa, testemunha que 0 interesse pela arqueologia nunca morre. (TSAAB, junho 1987, vol. 42, n. 145 , p. 4 - tradução livre, grifos nossos) ${ }^{8}$

Esse editorial, segundo nossa análise, tem como palavra-chave principal a Gestão Patrimonial e como secundária o Patrimônio Arqueológico, devido ao destaque que é dado aos temas em seu início, além da quantidade de parágrafos que lhes são destinados. Como podemos verificar, a dispersão dos assuntos nos textos levaria à indicação de outras palavras-chave. Entretanto, avaliamos que a discussão em torno dos dois níveis de análise realizados, palavras-chave principais e palavras-chave secundárias, é o foco da nossa dissertação.

A frase sublinhada no trecho um da citação acima trata da educação patrimonial sobre arte rupestre voltada para um público educado em inglês e em africâner, possivelmente, os donos das propriedades, terrenos e fazendas, onde estão presentes esses vestígios artísticos. Na frase sublinhada no trecho dois, presente no final do editorial, com um pouco menos de destaque em comparação com o primeiro, cita os nomes dos arqueólogos importantes na arqueologia sul-africana que continuam publicando trabalhos mesmo em idade avançada, os quais, pelo que fica entendido, são exemplos a serem seguidos quanto ao seu envolvimento com a disciplina.

\footnotetext{
${ }^{7}$ The Society [SAAS], in collaboration with the Southern African Society for Quartenary Research, has financed the printing of information leaflets in English and Afrikaans to publicise [sic] the plight of our rock art. We need the cooperation of every member of the Society to ensure that the information in the leaflet is spread as widely as possible. (TSAAB, junho 1987 , vol. 42 , n. 145, p. 3)

${ }^{8}$ May we extend greeting (some belated) to several Past Presidents of the South African Archaeological Society on their 80th birthdays: Cran Cooke, Gerhard Fock, Keith Robinson and Eduard van Zinderen Bakker, and to Desmond Clark and Jalmar Rudner on their 70 birthdays. The fact that we can call none of them truly 'retired' as they all continue to publish research results is testimony to the fact that an interest in archaeology never dies. (TSAAB, junho 1987, vol. 42, n. 145, p. 4)
} 
Nessa dispersão de temas que abarca a gestão patrimonial da arte rupestre e as referências aos antigos arqueólogos, se forma um caleidoscópio de imagens concernentes ao papel do arqueólogo africano e africanista conforme o esquema de imagens a seguir:

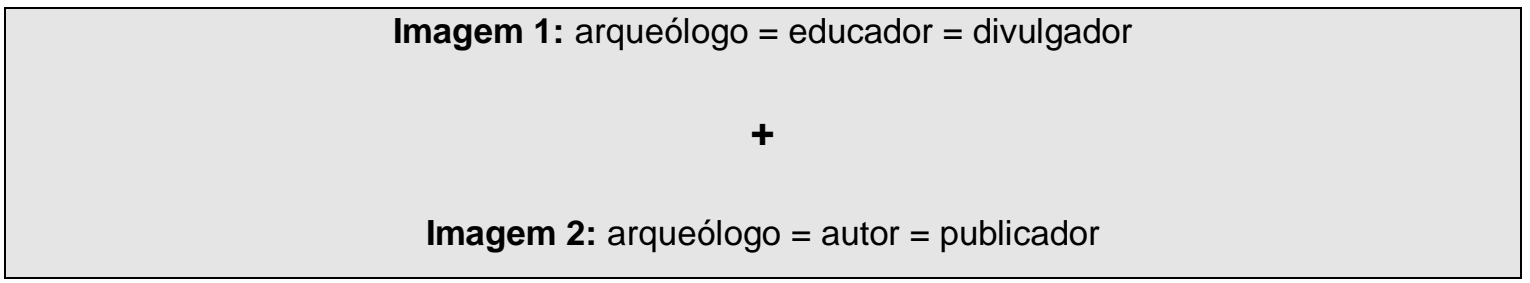

A sobreposição dessas imagens é a estratégia de construção do objeto "arqueólogo" nesse editorial no boletim TSAAB nesse período.

Para Foucault (1972, p.14-15), uma das limitações das metodologias similares às de Dyson (1985), Lyman et al. (2005), Bedin (2003) e Lopes (2002) é a busca de uma unidade nas fontes documentais seja pelo tipo de suporte, pelo tema, pelo autor ou pelo recorte temporal. O problema desses procedimentos é que eles se fundam, a nosso ver e a partir da leitura de Foucault (1972), em um princípio de categorização antes mesmo da análise qualitativa dos discursos das fontes. De outra forma, o autor critica a busca de continuidade ou de linearidade nas fontes que tem como um fim em si mesmo: remontar as origens e a sequência de fatos que gerou a documentação analisada. Ainda critica o método de análise documental que se preocupa em constituir os conjuntos e subconjuntos procurando fora dos documentos à explicação para eles existirem como o são.

Nota-se que a nossa análise do corpus também inclui a metodologia de Foucault (1972). Esta é constituída de procedimentos para estabelecer as correlações entre os recursos discursivos, que o autor chama de "elementos discursivos", dispersos em diferentes séries documentais como ocorre com esse conjunto formado pelos editoriais de três boletins arqueológicos. Para ele, o discurso é um acontecimento singular e o estudioso da fonte deve considerar em sua análise fatores que vislumbrem a especificidade do jogo de correlações de seus "elementos discursivos". 
Esse jogo de correlações tratado por Foucault (1972) é o conjunto de regras pelas quais os "elementos discursivos" do texto estabelecem conexão entre si para tratar de um tema. Segundo Machado (1981: 165): "O ponto importante da análise é que as regras que caracterizam um discurso como individualidade se apresentam sempre como um sistema de relações." O autor segue mais adiante:

[A análise de Foucault] não permanece unicamente ao nível do discurso, embora esse seja o seu objeto, aquilo para o qual tudo converge, mas busca estabelecer uma relação com acontecimentos de outra ordem, seja ela técnica, econômica, social ou política. (MACHADO, 1981, p. 166)

Nesse sentido, em nossa análise, o jogo de correlações dos recursos discursivos presente nos editoriais é estabelecido antes pelas regras das SAAS, SAfA e CICIBA que veiculam os papéis dos arqueólogos africanos e africanistas por meio dos textos dos seus boletins. Devido a esse mecanismo linguístico e discursivo, o qual se vale de temas dispersos nos enunciados, citações e ilustrações, o arqueólogo passa a ser de fato um objeto em construção nos editoriais através de uma estratégia de sobreposição ou de oposição das "imagens" ditadas por tais sociedades. Além do mais, esse jogo de correlações é influenciado pelas novas interações que foram estabelecidas entre essas corporações e outras instituições arqueológicas, a sociedade civil e a política.

Essa é a ideia subjacente que podemos deduzir dos dois trechos que acabamos de analisar. Outras citações exemplificam a nossa perspectiva. O primeiro editorial do boletim Nsi, datado de 1987, apresenta as seguintes "imagens" dos "arqueólogos" que trabalhavam na região circunscrita aos países do CICIBA:

Muitos deles [arqueólogos], isolados, sem acesso às principais publicações, trabalhavam com recursos mínimos e ignoravam tudo ou parte do que está sendo feito no exterior. (Nsi, 1987, n.1, p.1 tradução livre, grifos nossos) $)^{9}$

Diante disto, o editor justifica o lançamento do boletim Nsi no mesmo primeiro editorial:

\footnotetext{
${ }^{9}$ Nombre d'entre eux, isolés, sans accès aux grandes publications, oeuvrent avec des moyens dérisoires et ignorent tout ou partie de ce qui çe fait ailleurs. (Nsi, 1987, n.1, p.1)
} 
Finalmente o Nsi informará os seus leitores dos grandes eventos internacionais (seminários, conferências, simpósios) ocorridos e que ocorrerão pelo mundo e que interessam direta ou indiretamente à arqueologia. (Nsi, 1987, n.1, p.2 - tradução livre, grifos nossos) ${ }^{10}$

Os recursos discursivos, que Foucault (1972) cunha de "elementos discursivos", corresponde, no nosso caso, às escolhas realizadas dentre um repertório possível do conjunto de regras da SAAS, SAfA e CICIBA, no instante da escrita e da publicação (FOUCAULT, 1972, p.34-35).

Em relação aos dois trechos do boletim Nsi, que pertence ao CICIBA, são apresentados os recursos discursivos, que foram por nós sublinhados, para realizar a oposição de imagens do arqueólogo antes e depois do seu lançamento:

Imagem 1: o que o arqueólogo não deve ser é indicado pela presença das palavras isolados, sem acesso e ignoravam.

$\mathbf{X}$

Imagem 2: a visibilidade que o arqueólogo deve ter é indicada presença das palavras exterior, eventos internacionais e mundo.

Observamos nesses enunciados uma oposição imagética sobre o objeto "arqueólogo" naquele momento para o CICIBA. O jogo de correlações no primeiro editorial do boletim Nsi foi marcado pela oposição dos recursos discursivos para dar mais destaque para o seu lançamento. Logo, foi gerado um editorial cuja regra para a formação da imagem do "arqueólogo" seria diferenciar o que era a situação desses especialistas até então - isolamento e precariedade de trabalho - e a nova situação a partir do lançamento da publicação - visibilidade e abertura. Anos depois, em editorial do Nsi de 1991, consta um mapa da distribuição do boletim entre 239 pesquisadores e instituições de pesquisa pelo mundo. Observe:

\footnotetext{
${ }^{10}$ Enfin NSI informera ses lecteurs des grandes manifestations internationales (colloques, congrès, symposium) tenus et à venir de par le monde et qui intéressent de près ou de loin l'archéologie. (Nsi, 1987, n.1, p.2)
} 


\section{Mapa 1 - Distribuição do boletim NSI entre 239 pesquisadores e instituições de pesquisa entre os anos de 1987-1991.}

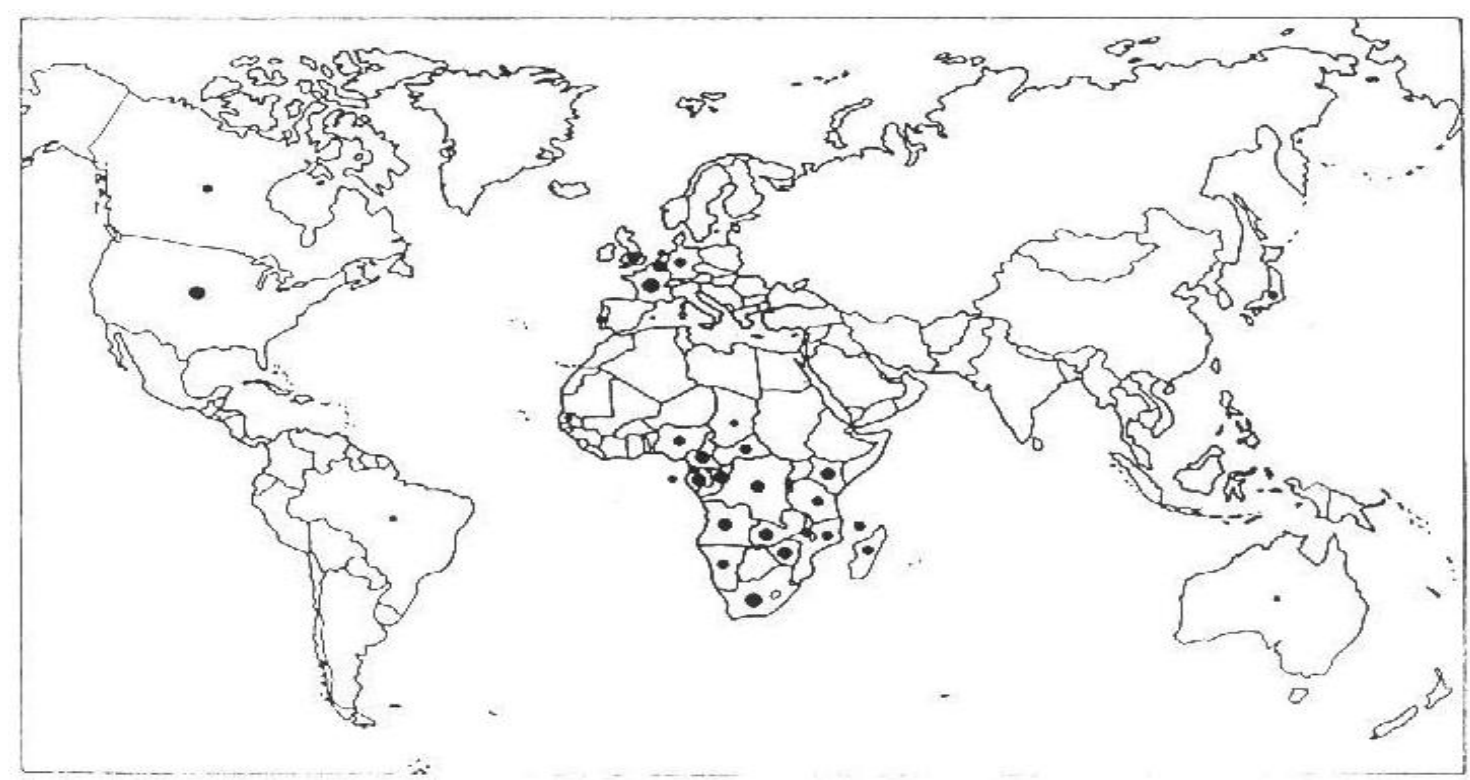

Fonte: Nsi, 1991 ,n.8-9, p.3.

Esse mapa é um dos recursos discursivos participantes do jogo de correlações do editorial, no qual uma regra para construir a imagem do "arqueólogo" é a formulação da oposição já mencionada: isolamento $e$ precariedade de trabalho $x$ visibilidade e abertura. Informa-nos a rede de arqueólogos ligados por meio do boletim, sugerindo a superação do isolamento por parte desses profissionais que trabalham na região dos países do CICIBA e que são leitores/colaboradores do Nsi. Observa-se que há um indicador isolado no centro do Brasil, dos Estados Unidos, do Canadá e da Austrália e a concentração de pontos na África Central e Austral além da Europa. Isso é avaliado como um resultado "globalmente positivo" para seus editores (Nsi, 1991, n.8-9, p.3).

Nesse sentido e retomando a discussão metodológica de Foucault (1972, p.37), que afirma:

Trata-se, de fato, de arrancá-los [os discursos] de sua quaseevidência, de deliberar os problemas que colocam; reconhecer que não são o lugar tranquilo a partir do qual pode-se colocar outras questões (sobre sua estrutura, sua coerência, sua sistematicidade, suas transformações), mas que colocam por si mesmos todo um feixe de relações [...]. Trata-se de reconhecer que eles não sejam, afinal de contas, o que se acreditava que fossem ao primeiro olhar. 
Analisar o corpus documental nessa perspectiva implica em "desconfiar" das unidades temáticas previamente estabelecidas sobre a produção de editoriais nos boletins das sociedades arqueológicas e, aparentemente, constatadas no levantamento das palavras-chave principais. Dito de outro modo, devemos colocar em suspenso uma caracterização da natureza do corpus documental centrada na organização do boletim e na gestão patrimonial e, diante da metodologia de Foucault (1972), focarmos o olhar para os recursos discursivos e as regras, segundo as quais os enunciados dos editoriais são construídos para versar sobre os temas indicados, conforme o levantamento das palavras-chave secundárias.

Segundo Foucault (1972, p.100-101, 144), o enunciado é a unidade elementar do discurso que pode ser isolada e entrar em relação com outros enunciados ou demais elementos discursivos. Em nosso caso, as citações textuais, as ilustrações e os mapas que aparecem entram em relação com outros recursos textuais para constituir as imagens dos arqueólogos africanos e africanistas. Para ilustrar essa perspectiva podemos citar outros editoriais. É o caso do trecho do editorial de John Bower do boletim NA, datado de dezembro de 1993, que faz uma citação de Peter Ucko. Este prefaciou o livro The Archaeology of Africa: food, metals \& towns, de 1993, cujos editores são T. Shaw et al:

[...] Ucko reclamou dos problemas especiais de editoração ao lidar com artigos sobre arqueologia africana, entre os quais [o problema do] orgulho do lugar [do editor transformado] em desencanto editorial deve-se aos problemas de referência [....] [P]oucas das convenções dos padrões normais das referências acadêmicas se aplicam à grande maioria das publicações sobre arqueologia africana, se escritas por africanos, americanos ou europeus." (NA, dezembro 1993, n.40, p.1 - tradução livre, grifos nossos) ${ }^{11}$

No mesmo editorial destacamos o seguinte trecho:

O objetivo mais direto desta pequena crítica é, claro, para incentivar os autores a exercer maior cuidado - na verdade, um nível profissional de cuidado - na preparação do material para o Nyame Akuma, especialmente no que diz respeito às citações. [...] Eu acho

\footnotetext{
${ }^{11}$ [...] Ucko complained about the special editorial problems of dealing with articles on African archaeology, among which 'pride of place in editorial disenchantment must lie with the problems of referencing.... [F] ew of the conventions of normal academic referencing standards apply to the vast majority of publications on African archaeology whether written by Africans, Americans or Europeans.' (NA, dezembro 1993, n.40, p.1).
} 
que todos nós que estamos envolvidos em preparar arqueólogos africanistas precisamos responder à reclamação de Ucko para ter certeza de que os nossos alunos estão bem e completamente instruídos nos aspectos formais da escrita acadêmica, incluindo a própria citação. (NA, dezembro 1993, n.40, p. 1, - tradução livre, grifos nossos) $^{12}$

A citação textual do prefácio de Peter Ucko insere-se como um recurso discursivo no jogo de correlações presente no editorial. A regra do jogo de correlações do boletim NA pertencente a SAfA é estabelecer enunciados que o apresente seriamente como uma publicação de alto padrão. Os arqueólogos que desejam publicar neste veículo devem ser criteriosos quanto à escrita acadêmica dos seus trabalhos. Afinal, o tipo do especialista tido como ideal nos editoriais desse boletim preocupa-se com a visibilidade, com a produção de textos acadêmicos com escrita padronizada e com a publicação dos seus textos em revistas de alto nível.

Para Foucault (1972), o enunciado existe em razão de um "referencial", de um "sujeito" que, no nosso caso, corresponderia à posição de editor ou da corrente majoritária da sociedade arqueológica ou científica que ele representa - de um "campo associado" - do repertório de temas dessas sociedades e - de uma "materialidade" - do estatuto ou normas das SAAS, SAfA e CICIBA.

O referencial do enunciado forma o lugar, a condição, o campo de emergência, a instância de diferenciação dos indivíduos ou dos objetos, dos estados de coisas e das relações que são postas em jogo pelo próprio enunciado; define as possibilidades de aparecimento e de delimitação do que dá à frase seu sentido, à proposição seu valor de verdade. (FOUCAULT, 1972, p.114-115)

De modo sintético, a nossa discussão metodológica até o momento foi baseada em Lyman et al. (2005) no que se refere a metodologia para a criação de um banco de dados; em Dyson (1985), em relação à identificação das palavras-chave dos editoriais; e, em Foucault (1972), para identificar e interpretar o jogo de correlações dos temas dos editoriais que foram apontados pelo levantamento das palavras-chave principais e secundárias.

\footnotetext{
${ }^{12}$ The most direct purpose of this little diatribe is, of course, to encourage authors to exercise greater care - indeed, a professional level of care - in preparing material for Nyame Akuma, especially as regards citations. [...] I think all of us who are envolved in training africanist archaeologists need to respond to Ucko's complaint by making sure our students are well and thoroughly instructed in the formal aspects of scholarly writing, including proper citation. (NA, dezembro 1993, n.40, p.1)
} 
Cabe retomar também a nossa discussão metodológica. No primeiro momento do estudo, consideramos que a recorrência dos temas nos enunciados dos trinta e quatro editoriais visualizada pelo levantamento das palavras-chave principais - organização do boletim e gestão patrimonial consolida a construção das imagens dos arqueólogos africanos e africanistas como podemos observar nos próximos trechos dos editoriais.

Sobre gestão patrimonial, o convidado Jannie Loubsier afirma em editorial da TSAAB datado de dezembro de 1990:

Entre outras coisas, os conservadores sentiam que os arqueólogos ignoravam a ética da conservação básica em relação aos sítios, ao material escavado e aos proprietários tradicionais. Alguns até chegaram ao ponto de chamar os arqueólogos de "vândalos" e "imperalistas culturais". [...] A incorporação da ética e das habilidades de conservação básica em cursos de arqueologia em universidades sul-africanas é, portanto, vital. (TSAAB, dezembro 1990, v.45, n.152, p.71 - tradução livre, grifos nossos) ${ }^{13}$

Em 1998, o editor, diretor de pesquisa do Nsi, faz a seguinte afirmação sobre o diferencial do boletim no que se refere à escolha dos colaboradores da publicação:

Os dezesseis cientistas que colaboram nesta primeira edição de 1988 são todos residentes no continente africano, mais capazes de compreender as realidades do cotidiano da sub-região. Duas exceções, James Denbow e Bernard Farine. (Nsi, 1988, n.3, p. 3 tradução livre, grifos nossos) ${ }^{14}$

Ainda sobre a organização do boletim David Lubell, editor da NA, em abril de 1987, informa que o processo editorial será informatizado e eles utilizarão um scanner ótico para ler os manuscritos e poupar o trabalho do editor de redigitá-los para a publicação. A seguir o trecho que instrui os arqueólogos para a submissão dos textos:

\footnotetext{
13 Among other things, conservators felt that archaeologists were unaware of basic conservation ethics concerning sites, excavated material and traditional owners. Some even went so far as to call archaeologists 'vandals' and 'cultural imperialists'. [...] Incorporation of basic conservation ethics and skills in archaeology courses at South African universities is therefore vital. (TSAAB, dezembro 1990, v.45, n.152, p.71)

${ }^{14}$ Les seize scientifiques qui ont collaborés à ce premier numéro de l'année 1988 sont touts résidents sur le continent africain, mieux à même de cerner les réalités quotidiennes de la sous région. Deux exceptions, James Denbow et Bernard Farine. (Nsi, 1988, n.3, p. 3)
} 
2. [P]or favor envie uma cópia do seu manuscrito em um disquete de 5"1/4 ou 3" 1/2 polegadas, bem como cópia impressa. Eu uso o [processador de texto] WordStar em uma máquina CP/M, mas ela geralmente pode ler qualquer arquivo ASCIl escrito em qualquer CP/M ou no formato MS.DOS bem como [textos] escritos em um Apple Macintosh. Por favor me diga qual o tipo de máquina e o software que você usou para escrever [o texto]. Eu devolverei todos os disquetes. (NA, abril 1987, n.28, p. 1 - tradução livre, grifos nossos) $^{15}$

Nesses três trechos citados, após o levantamento das palavras-chave principais, identificamos, no primeiro editorial, a gestão patrimonial e, nos dois seguintes, a organização do boletim. As imagens que são formadas na construção das representações dos arqueólogos africanos e africanistas são respectivamente:

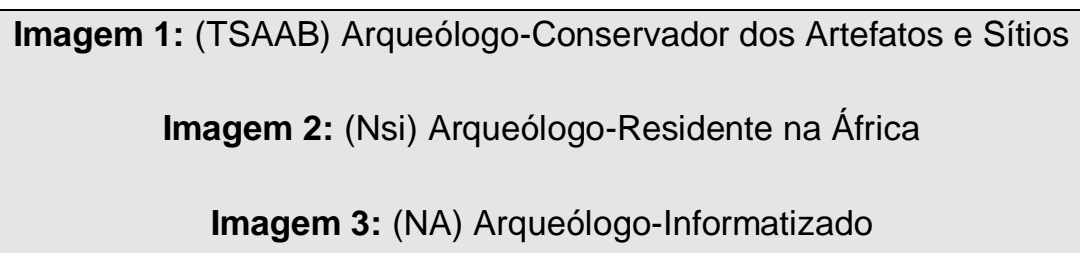

Como a diversidade de temas abordados nos editoriais não fica visível somente com o levantamento dessas palavras-chave principais partimos para a análise, num segundo nível, com o elencamento e estudo das palavraschave secundárias que é a especificação da palavra-chave principal.

Para exemplificar o nosso raciocínio, analisaremos a primeira imagem formada no trecho citado do TSAAB, de dezembro de 1990. Esse editorial apresenta a palavra-chave secundária patrimônio arqueológico. Esta nos indica que, para o TSAAB, a orientação para formar a imagem do arqueólogo é criar um jogo de relações entre os enunciados que justifique a preocupação de conservar os artefatos e sítios sul-africanos. Nesse momento, a grande preocupação da SAAS é estabelecer uma nova relação entre ela, seus membros e a sociedade civil em meio aos conflitos civis do fim do regime segregacionista. Fez sentido para a SAAS, naquele momento, a mudança nos procedimentos do trabalho de campo relacionada com uma proposta de interação com as comunidades - proprietárias tradicionais - na perspectiva da

\footnotetext{
${ }^{15}$ 2. [P]lease send a copy of your manuscript on a 51.4 or 31.2 inch disk as well as hard copy. I use WordStar on a CP/M machine, but can usually read any ASCII file written in either CP/M or MS.DOS format as well as disks written on an Apple Macintosh. Please tell me what kind of machine and word processing software were used to write the disk. I will return all disks. (NA, abril 1987, n.28, p. 1)
} 
Arqueologia Comunitária, ainda que a imagem construída do arqueólogoeducador-divulgador imprimisse uma tutela sobre as comunidades.

\section{Sobre as imagens dos arqueólogos africanos e africanistas}

Os editoriais dos boletins TSAAB, NA e Nsi são construções retóricas que engedram as imagens dos arqueólogos africanos e africanistas. Segundo Shanks apud Aldrovandi (2009, p. 46):

Uma imagem objetiva, uma verdadeira representação da realidade, é aquela conectada a algo mais sólido que ela mesma, de forma que, se for considerado não-representativa, tudo aquilo a que ela está conectada fica ameaçado de ruir. Retórica é a arte e a ciência de fazer tais conexões e persuadir as pessoas de sua força.

Constatam-se, a partir dessa definição, que as imagens são produtos das realidades percebidas pelos porta-vozes das sociedades científicas, em um contexto histórico de estilhaçamento do mundo colonial. São expressas como objetivas pelos editores e foram dramaticamente construídas diante da possibilidade de não serem consideradas representativas do que era ser arqueólogo africano e africanista naquelas circunstâncias. Daí que essas imagens fortalecem a ideia de inevitabilidade da regulação das práticas e pensamentos dos arqueólogos por parte das sociedades científicas que publicam os boletins. Os editoriais, assim, têm a finalidade de apresentar como necessário e eficaz o olhar legitimizador das sociedades científicas ante aos leigos e diante das circunstâncias históricas da prática da profissão arqueológica nas décadas de 1980 e 1990.

Sob a luz da metodologia de Foucault (1972), investigamos o nosso corpus documental partindo de quatro perspectivas de abordagem:

1‥ Os enunciados recorrentes dos editoriais formulam as imagens dos arqueólogos africanos e africanistas;

2a . Esses enunciados (frases, citações e figuras), considerados em sua recorrência e diversidade próprias, são específicos desse suporte material, o qual é nomeado editorial dos boletins; 
3ª. Esses boletins são produzidos por sociedades científicas e, especificamente arqueológicas, que apresentam regras ("estatutos") postas em práticas no discurso dos editoriais conforme o jogo de relações que as engendra;

4a. As práticas discursivas podem mudar quando novas relações entre os arqueólogos são estabelecidas ao longo do tempo com outras instituições científicas, a sociedade civil e os regimes políticos.

Essas quatro perspectivas de abordagem avançam além da discussão dos traços de personalidade e da ideologia dos editores e foca - nas formações discursivas editoriais - nas imagens dos arqueólogos construídas nos editoriais dos boletins das sociedades científicas. "O que é ser arqueólogo da África e na África?". Sua resposta tem caráter normativo, descritivo e prescritivo, liga os enunciados entre si (SAID, 2005; SARLO 2005). Ela é reverberada nos trinta e quatro editoriais que apresentam opiniões sobre a natureza da profissão do arqueólogo africano e africanista.

A diversidade temática dos editoriais é resultado da riqueza e complexidade das formações discursivas que efetivamente constituem as imagens dos arqueólogos africanos e africanistas (FOUCAULT, 1972, p.45). A SAAS, a SAfA e o CICIBA, no período de 1987 a 1993, focaram na construção dessas imagens nos editoriais dos boletins. Essa construção tomou como base as regras $\theta$ ou estatutos das sociedades arqueológicas quanto à participação dos arqueólogos nessas instituições e na sociedade civil. As relações institucionais, sociais e ideológicas entre os arqueólogos africanos e africanistas caracterizam a formação da imagem - "Arqueólogo" - e o modo como os temas são tratados nos editoriais. Foucault (1972, p.45, 89, 161-163) nomeia os chamados estatutos como o jogo de regras ou como o arquivo que dá unidade aos discursos durante um período e que constituem e/ou modificam o seu objeto.

Essas regras resultam na diversidade dos temas presentes nos editoriais, conforme vimos no levantamento das palavras-chave secundárias. A identificação dos critérios de escolhas temáticas desvela as superfícies de emergência das imagens, ou do objeto, na terminologia de Foucault (1972), no período de 1987 a 1993. Essa identificação igualmente desvela as instâncias 
de delimitação das imagens nos editoriais e as grades de especificação das imagens nos diferentes discursos dos editoriais (FOUCAULT, 1972, p.55-56).

As superfícies de emergência, termo cunhado por Foucault (1972), das imagens dos arqueólogos estão vinculadas à questão do poder na disciplina arqueológica. Os editoriais são palco de um embate dentro das sociedades científicas para a veiculação da imagem dos arqueólogos, objeto em construção nas fontes selecionadas, ou melhor, uma luta originada da natureza das relações que estavam estabelecidas entre arqueólogos africanos e africanistas, como já feito referência inicialmente. Entre os anos de 1987 e 1993, as interpretações das condições históricas, políticas e sociais, por parte das sociedades científicas, representadas pelos editores dos boletins, deram tom aos editoriais em relação à construção das imagens dos arqueólogos. Assim, o editorial, enquanto discurso, é a prática de constituir as imagens dos arqueólogos. Esse tipo de análise foi nomeado por Foucault (1972, p.60-61, 64, 151) como o estabelecimento das relações discursivas do corpus documental.

No nosso conjunto documental, o discurso dos editoriais - enquanto prática de constituição das imagens - assenta-se em um sistema de dispersão de temas. Foucault (1972) nomeia sistemas de dispersão a descrição das regras de repartição do discurso - as lacunas, incompatibilidades e misturas. Retomando o texto do autor:

\begin{abstract}
Essa raridade dos enunciados, a forma lacunar e retalhada do campo enunciativo, o fato de que poucas coisas, no total, podem ser ditas, explicam que os enunciados não sejam, como o ar que respiramos, de uma transparência infinita; mas coisas que se transmitem e se conservam, que têm um valor, e das quais procuramos nos apropriar; que se repete, que se reproduz e que se transforma; às quais se dá estatuto na instituição; coisas que são desdobradas não apenas pela cópia ou pela tradução, mas pela exegese, pelo comentário e pela proliferação interna do sentido. (FOUCAULT, 1972, p.150)
\end{abstract}

Nesse sistema de dispersão identificamos os enunciados referentes à cobertura geográfica dos boletins. O primeiro editorial do TSAAB, assinado por A.J.H. Goodwin, datado de dezembro de 1945, define que as regiões abordadas iriam da África central ao Cabo, conforme o subtítulo do boletim naquele ano. Mas de fato, segundo o editor, a cobertura geográfica abrange 0 Cabo, a União e os estados vizinhos - Rodésia do Sul, Suazilândia, Sudoeste da África. Já, o primeiro editorial do NA, assinado por Peter L. Shinnie, datado 
de outubro de 1972, determina a cobertura geográfica como sendo todo o continente africano e excetua o Egito e o Norte da África históricos. Por fim, o primeiro editorial do Nsi, assinado pela Direction Genérale du CICIBA, do ano de 1987, restringe a cobertura geográfica aos países membros do CICIBA em dezembro de 1986, falantes de línguas de origem bantu na África Central, Oriental e Meridional: República Centro-Africana, Guiné Equatorial, São Tomé e Príncipe, Gabão, Congo, Zaire, Ruanda, Angola, Zâmbia e Comores.

A cobertura cronológica também abrange um conjunto de enunciados pertinentes a esse sistema de dispersão. O TSAAB preocupa-se com o período desde o surgimento do homem até o "alvorecer da história"; o NA aborda todos os períodos, excluindo o Egito e o Norte da África históricos; e, o Nsi refere-se aos últimos quatro mil anos para compreender a expansão bantu. A abordagem da África subsaariana antiga, circunscrevendo as áreas dos povos falantes de línguas de origem bantu, são características comuns dos três boletins.

Além de buscar compreender o sistema de dispersão dos temas nos editoriais, nós direcionamos o nosso olhar para a figura dos editores visando compreender

"[q]uem, no conjunto de todos os indivíduos-que-falam, está autorizado a ter esta espécie de linguagem? [...] Qual o estatuto dos indivíduos que têm - e apenas eles - o direito regulamentar ou tradicional, juridicamente definido ou espontaneamente aceito, de proferir semelhante discurso?" (FOUCAULT, 1972, p.65).

Para essa empreitada, pesquisamos, tanto no corpus documental quanto em outras fontes, os dados pertinentes aos critérios de competência e de saber reconhecidos pelas sociedades arqueológicas e que diferenciam os editores dos outros membros da instituição.

Os critérios de competência identificados na análise do corpus documental e na pesquisa de fontes externas foram: formação acadêmica, atuação para a profissionalização da disciplina, atuação junto à produção e divulgação do conhecimento arqueológico. Já, os critérios de saber identificados no corpus relacionam-se ao posicionamento do editor sobre o objeto do discurso: o arqueólogo africano e africanista. Os posicionamentos 
dos editores, considerando esses critérios identificados, serão retomados em análise pormenorizada nos capítulos 4,5 e 6 .

Em suma, baseados na metodologia de Foucault (1972, p.90, 119-120) buscamos compreender o jogo de regras que possibilita ao sujeito-discursante - o editor - selecionado pelos critérios de competência e saber, o qual ocupa concomitantemente as posições de sujeito-que-observa, sujeito-que-seleciona e sujeito-que-transcreve, escrever os editoriais com determinados elementos discursivos para determinado público-leitor.

$\mathrm{Na}$ etapa seguinte, identificou-se, descreveu-se e se relacionou os lugares institucionais que originam o discurso dos editoriais e os locais onde esses discursos são aplicados (FOUCAULT, 1972, p.66). Com base na análise do corpus documental, verificamos que os lugares institucionais que são pontos de origem e de aplicação dos discursos dos editoriais são: as sociedades arqueológicas, os congressos arqueológicos, o "campo" e o laboratório e as salas de aula das universidades africanas, norte-americanas e europeias onde esses boletins mais circularam concomitantemente. Sua identificação permite descrever os tipos de "arqueólogos" promovidos em nome da sociedade científica.

A perspectiva foucaultiana de que o discurso encerra um conjunto de relações que pode ser descrito como regras para a formação do próprio editorial nos orientou durante a sistematização dos dados do corpus documental. Esse viés nos levou a compreender a especificidade da prática discursiva nos editoriais. Na definição do autor:

[A prática discursiva] é um conjunto de regras anônimas, históricas, sempre determinadas no tempo e no espaço, que definiram, em uma época dada, e para uma determinada área social, econômica, geográfica ou linguística, as condições de exercício da função enunciativa. (FOUCAULT, 1972, p.147)

Para caracterizar esse conjunto de regras lançamos mão dos primeiros editoriais, por apresentarem os enunciados discursivos e temas que são retomados nos editoriais do período de 1987 a 1993, definindo assim o chamado campo de presença para Foucault (1972). Esses primeiros editoriais são o passado do corpus documental, porque apresentam elementos para 
estabelecer o repertório sobre o que os editores posteriores podem discursar; 0 que é incompatível com a publicação; e, o que pode ser modificado com as novas relações estabelecidas (FOUCAULT, 1972, p.155). Em outras palavras, apresentam as regras (ou o "estatuto") da sociedade científica veiculadas pelo boletim no ato da sua publicação.

A diversidade temática dos editoriais que, ao fim e ao cabo, ajuda a confirmar as imagens construídas dos arqueólogos pelas sociedades científicas, corresponde ao chamado campo de concomitância (FOUCAULT, 1972, p.73). Nessa definição cabem os elementos, temas e enunciados discursivos referentes ao processo de informatização do fluxo editorial dos boletins, identificados no levantamento das palavras-chave secundárias. Assim, para identificar as imagens dos arqueólogos africanos e africanistas, fez-se necessário verificar como os elementos dispersos nos discursos dos editoriais estavam relacionados tanto no campo da presença quanto no da concomitância. A forma de agrupar os enunciados discursivos e os temas eram estratégias institucionais para demarcar o jogo de relações pertinentes à constituição das imagens dos arqueólogos. Essa prática discursiva constituída de regras caracteriza a natureza dos discursos dos editoriais dos boletins de arqueologia, ou como diz Foucault (1972, p.92), o sistema de formação do discurso.

Por fim, como apresentaremos no capítulo 7, buscamos compreender a natureza da relação entre os três boletins que circularam concomitantes entre 1987 e 1993. A análise do corpus documental indica uma relação de complementaridade apesar da aparente oposição entre os enunciados discursivos. Cada boletim apresenta nuances na abordagem do objeto e ao serem lidos comparativamente eles formam um conjunto de imagens complementares correntes no período sobre o que é ser arqueólogo africano e africanista. 


\title{
2. A TRAJETÓRIA DA PESQUISA ARQUEOLÓGICA NA ÁFRICA
}

\begin{abstract}
A arqueologia africana tem muitos passados: pré-colonial, colonial, imperialista, nacionalista, pós-colonial e neo-colonial. No entanto, estes passados têm uma coisa em comum importante: eles são o produto de "outros". (SEGOBYE, 2005, p.81 - tradução livre) ${ }^{16}$
\end{abstract}

Neste capítulo nos debruçamos sobre os contextos históricos da produção do conhecimento arqueológico por africanistas e africanos. O estudo da História da Arqueologia da África Central e Austral nos possibilita uma melhor interpretação dos editoriais dos boletins arqueológicos TSAAB, NA e Nsi no período entre 1987 e 1993.

Entre o final do século XIX e as independências das colônias africanas, em meados do século XX, a pesquisa arqueológica na África e sobre a África e, particularmente, sobre as regiões Central e Austral, esteve imersa em interesses de apropriação científica do continente, fatiado pelas nações europeias, como podemos observar no mapa dois (abaixo). Para o melhor aproveitamento das matérias-primas e para o aprimoramento do domínio do território das colônias era imprescindível escrutiná-las, revirar as pessoas, as terras, os animais, as plantas, enfim, aplicar a terminologia e as metodologias científicas em voga nas metrópoles (TAVARES e SANTOS, 2002).

\footnotetext{
${ }^{16}$ African archaeology has many pasts: pre-colonial, colonial, imperialist, nationalist, post-colonial and neo-colonial. However, these pasts have one major thing in common: they are the product of 'others'. (SEGOBYE, 2005, p.81)
} 


\section{Mapa 2 - Mapa político da África em 1900}

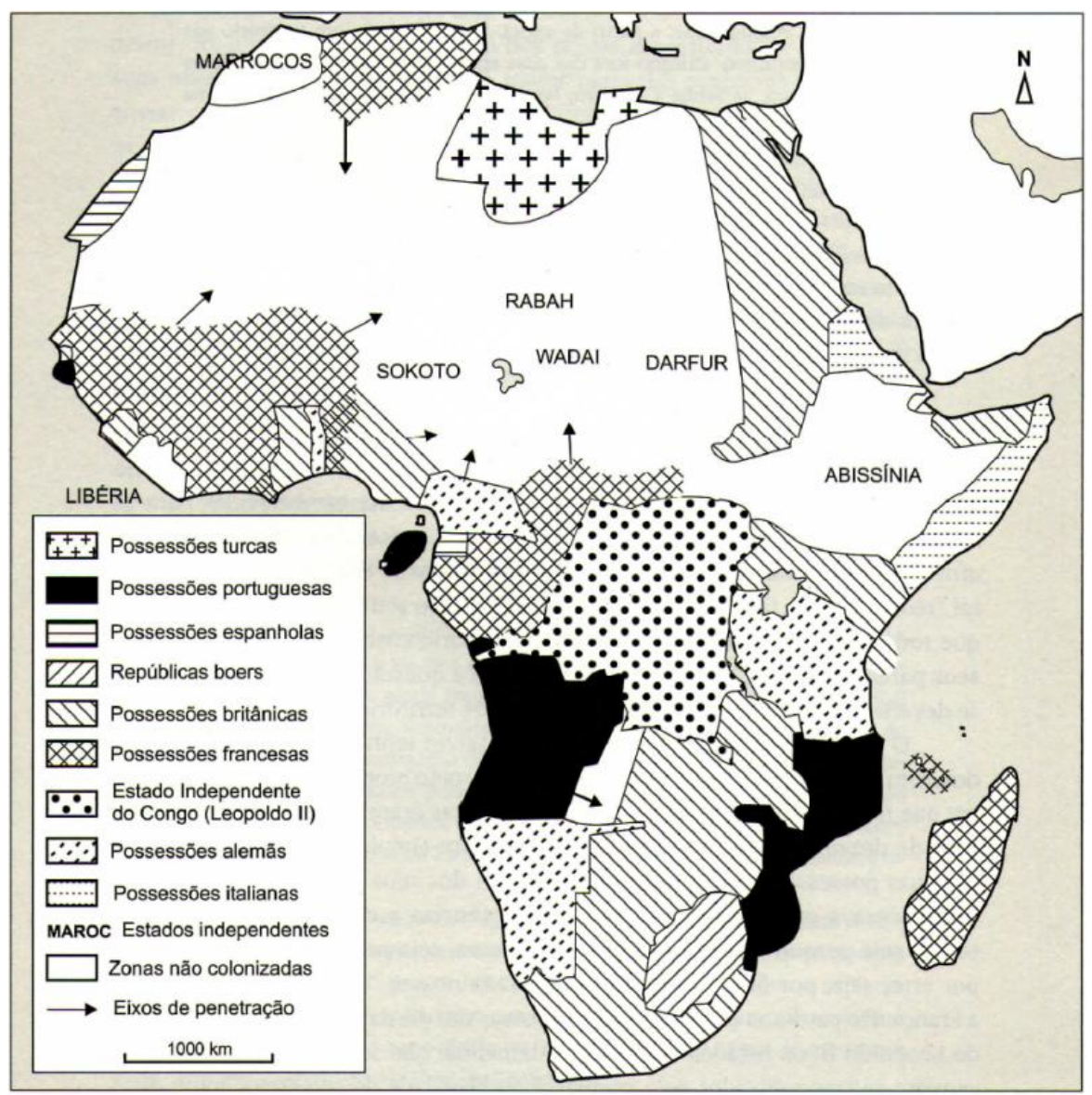

Fonte: M'BOKOLO, 2011, p. 362.

Em uma perspectiva eurocêntrica, a arqueologia começou a constituir-se na Europa na segunda metade do século XIX (RENFREW e BAHN, 1993). Segundo esses autores, nessa época, o geólogo Charles Lyell (1797-1875) defendeu o princípio do uniformitarismo que, por sua vez, assentava-se no princípio da estratificação das rochas publicado por James Hutton, em 1785, o qual é uma das bases da prática da escavação arqueológica. Esse período também é marcado pela atuação de Charles Darwin (1809-1882) que estabeleceu o conceito da evolução das espécies com a publicação dos livros "A origem das espécies" (1859) e "A origem do homem" (1871). Devemos considerar ainda o sistema das três idades - Pedra, Bronze e Ferro, depois subdividido em Paleolítico, Neolítico, Bronze e Ferro - elaborado, em 1836, por C.J.Thomsen (1788-1865), cuja terminologia foi pensada para dar sentido aos artefatos "pré-históricos" localizados na Europa. Essa terminologia inicialmente foi utilizada pela arqueologia colonial para definir os artefatos achados na África. Segundo Renfrew; Bahn (1993): 
Estes três grandes avanços conceituais - a antiguidade do homem, a teoria da evolução de Darwin e o sistema das três idades proporcionaram, ao fim, um marco para o estudo do passado e para fazer perguntas sobre o assunto. (RENFREN e BAHN, 1993, p.25 tradução livre) ${ }^{17}$

Nesse sentido, esses princípios marcaram a arqueologia colonial no que se refere à produção de africanistas e africanos no princípio do século XX. Segundo Shepherd (2002): "A Arqueologia, tanto como disciplina quanto como ideia, foi introduzida na África como parte do processo de expansão colonial."18 (p.192 - tradução livre). A disciplina, nesse momento, caracterizava-se pela introdução de métodos e paradigmas arqueológicos realizados na Europa e pelo interesse científico do colonizador em escrutinizar as colônias.

De modo geral, a primeira metade do século $X X$ foi marcada pelas explicações difusionistas sobre a origem das civilizações e das migrações transaarianas. Nas primeiras décadas, alguns arqueólogos africanistas e africanos envolveram-se na construção da disciplina com terminologia local própria, entre eles, Colette, no Congo-Kinshasa, e, Goodwin, na África do Sul, que mencionaremos mais adiante.

Após a Segunda Guerra Mundial, os arqueólogos africanistas e africanos introduziram os aprimoramentos da Física Nuclear e da Química, possibilitando uma revolução dos métodos de datação absoluta através da análise do carbono $\left(\mathrm{C}^{14}\right)$ na composição dos artefatos e dos restos de matéria orgânica do contexto arqueológico. A datação radiocarbônica aplicada aos contextos arqueológicos do continente africano libertou os especialistas do cenário das cronologias relativas baseadas na comparação com as datas estabelecidas na Europa nos estudos de coleções. (MITCHELL, 2002, p.34; PHILLIPSON, 2005, p.05)

A construção da arqueologia no continente africano resultou na realização do The First Pan-African Congress on Prehistory, sediado em Nairóbi, em 1947, com a reavaliação positiva dos vestígios do Australophitecus

\footnotetext{
${ }^{17}$ Estos tres grandes avances conceptuales - la antigüedad del hombre, la teoría de la evolución de Darwin y el Sistema de las Tres Edades - proporcionaron, al fin, un marco para el estudio del pasado y para plantearse preguntas sobre él. (RENFREN e BAHN, 1993, p.25)

${ }^{18}$ Archaeology, both as a discipline and as an idea, was introduced into Africa as part of the process of colonial expansion itself. (SHEPHERD, 2002, p.192)
} 
que comprovavam a tese da anterioridade da presença humana na África. Esta tese foi lançada por Raymond Dart, professor de anatomia, em artigo da revista Nature, em 1925, no qual fez a descrição do fóssil Taung, vestígio de um Australopithecus africanus. Atualmente esse fóssil foi datado, considerando as associações faunísticas, entre dois milhões e quatrocentros mil anos a dois milhões e oitocentos mil anos (MITCHELL, 2002, p. 46). O casal Louis e Mary Leakey também se destacou nesses estudos paleoantropológicos com a descoberta de fósseis na Garganta de Olduvai, África Oriental, como o caso do pequeno primata Kenyaphitecus wickeri datado de 14 milhões de anos (COPPENS, 2010, p.451).

Esses fatos alargaram a importância da arqueologia da África e do seu impacto sobre a especialidade em outros locais do mundo. Entretanto, o acontecimento foi avaliado diferentemente. Em uma publicação datada de 1931 Gertrude Caton-Thompson analisou as ruínas do Grande Zimbábue, na África Austral e concluiu quanto à origem africana das estruturas. A avaliação foi inovadora para a época. Até então, as explicações sobre essas ruínas relacionavam a Ophir, a terra paradisíaca do rei Salomão, ou direcionava a uma civilização caucasiana anterior aos negros, ou seja, o sítio era visto como vestígio de civilizações externas ligadas à história cristão-europeia. Essa segunda explicação foi disseminada pelo colonizador Cecil Rhodes da British South Africa Company (GABEL, 1985, p.245). Para Caton-Thompson, as estruturas do Grande Zimbábue eram africanas, pois eram "insuficientemente desenvolvidas para serem europeias" (SHEPHERD, 2002, p.194-5).

Em 1945, a arqueologia no continente foi marcada pelo estabelecimento da sociedade científica SAAS, na África do Sul, com arqueólogos profissionais e amadores apoiados por personalidades do governo local como o General Jan Smuts. Esse período é importante no processo de formação das elites intelectuais africanas preocupadas com o passado das colônias da África Central e Austral e, também, com o passado da África do Sul.

Segundo M'Bokolo (2011):

Alguns historiadores interrogaram-se sobre o mito da guerra como virada decisiva [das colônias africanas]. Contudo, todos são unânimes em considerar que a Segunda Guerra Mundial foi um 
momento crítico de aceleração das reivindicações africanas e de ascensão do movimento de libertação. (M'BOKOLO, 2011, p.565)

Daí, a grande expressão e impacto que as lutas anticoloniais e antiapartheid tiveram na Arqueologia da África e sobre a África nos anos subsequentes. A arqueologia nomeada nacionalista, das décadas de 1950, 1960 e 1970, era representativa de uma "era de esperança e orgulho", como se refere Shepherd (2002, p.199), para os arqueólogos conscientes da necessidade da descolonização ideológica da ciência feita sobre o continente. Um dos grandes personagens desse momento foi o senegalês Cheikh Anta Diop (1923-1986), com amplo conhecimento interdisciplinar em química, física, antropologia, arqueologia e história. Em 1966, ele fundou e foi diretor do "Laboratório de Radiocarbono do Instituto Fundamental da África Negra" da Universidade de Dakar, Senegal (NASCIMENTO, 1996, p.39).

As teses de Diop publicadas em 1955, 1959 e 1967, produzidas dentro dos padrões correntes na época da pesquisa acadêmica reconhecida internacionalmente, propuseram uma nova interpretação sobre o papel do continente africano na história geral: a África fora o berço da humanidade, em termos físicos e culturais. Segundo Diop apud Nascimento (1996, p.41): "desde há cinco milhões de anos até o fim do período glacial há dez mil anos, a África quase unilateralmente povoou e influenciou o resto do mundo." Em que pese à força da palavra unilateralmente, os estudos de arqueologia africana nessa perspectiva, na segunda metade do século XX, apontam, de fato, para a anterioridade do continente africano, seja quanto a origem do homem, seja em relação ao desenvolvimento da agricultura no Vale do Rio Nilo há 17.500 anos e seja em referência a criação de gado em Lukenya Hill nas proximidades de Nairóbi há 15.000 anos (NASCIMENTO, 1996, p.42).

Por sua vez, essa mesma arqueologia nacionalista praticada na África do Sul dos anos 1960 e 1970, ainda que concomitante ao movimento ideológico da "Black Consciousness" e às lutas políticas pelas independências das colônias africanas, difundiu as origens "exóticas" do sítio arqueológico Grande Zimbábue (SHEPHERD, 2002, p. 196). Esse fato nos leva a pensar nas implicações das diferentes arqueologias desenvolvidas no continente nessas décadas do século XX. 
As arqueologias nacionalistas desenvolveram-se em meio aos conflitos de poder que marcaram o passado e marcam o presente do continente africano, em busca da unidade nacional. Essas arqueologias concentraram nos estudos sobre as origens dos reinos e impérios e sua história no passado recente (TRIGGER, 1984, p.363). Por outro lado, Gabel (1985), Shaw (1997), Pwiti (1997) e Kibunjia (1997) afirmam que houve muitos problemas acarretados pela falta de investimento dos governos, após as independências, na preservação dos vestígios arqueológicos. Todavia, situemos o papel de Omar Bongo, ditador do Gabão entre 1967 e 2009, que investiu na fundação do CICIBA em 1983. Analisaremos esse papel de Bongo junto à sociedade científica publicadora do boletim Nsi ainda neste capítulo.

A fim de darmos continuidade a nossa análise, segundo Trigger (1984, p.356) há uma estreita relação entre a natureza da pesquisa arqueológica e o meio social em que ela é praticada. Este meio social é definido pelas regras econômicas, políticas e culturais das colônias e, posteriormente, dos Estados nacionais africanos.

As arqueologias da África Central e Austral foram influenciadas pelos temas da "União" e "Cooperação" entre os Estados nacionais oriundos do processo de independência. $O$ discurso de União foi reelaborado pelas elites políticas e intelectuais africanas mesmo antes do processo de libertação das colônias. Se na África do Sul, a evocação do tema, em meados do século XX, nos editoriais das décadas de 1940 e 1950, pretendia suavizar as disputas entre as elites partidárias dos africâners ou britânicos, a ideia de uma cooperação continental, começa a ser desenhada nos congressos e conferências. A primeira delas foi à de Manchester, no Reino Unido, em 1945; seguida de Kumasi, na Costa do Ouro, em 1953; de Acra, também na Costa do Ouro, em abril e dezembro de 1958; e, de Cotonu, em Benin, em julho de 1958. (M'BOKOLO, 2011, p.632) Esses eventos, em meio à proliferação dos partidos políticos comprometidos com a libertação total da África, alimentaram a participação política dos intelectuais africanos no processo de descolonização do passado e das arqueologias africanas. 
Segundo M'Bokolo (2011, p.545), entre o final do século XIX e o período de entre guerras constituiu-se uma elite de intelectuais africanos que participaram de um processo de independência incipiente através da divulgação do conceito de nacionalismo. O rompimento com a dominação colonialista era inexorável, segundo essas elites, amparadas na ideologia panafricanista esboçada na ideia de cooperação continental. Esse movimento de ruptura divergia quanto à aproximação seja dos Estados Unidos, seja dos países comunistas, que tentavam angariar adesões dos novos Estados nacionais africanos, que se formavam com as independências, ao bloco capitalista ou ao comunista.

Em meio a esse assédio, as elites intelectuais africanas dividiram-se em relação ao alinhamento aos blocos, à defesa da unidade africana e a não ingerência nos assuntos internos dos países do continente, o que influenciou a produção arqueológica na África Central e Austral.

A concretização de uma intervenção externa no Congo-Kinshasa deu-se a partir de 1963, quando foi assassinado Patrice Lumumba. Ainda neste ano, trinta e um chefes de Estados realizaram uma reunião em Addis Abeba, na Etiópia, na qual constituíram os princípios da Carta da Organização da Unidade Africana. A necessidade, dos participantes, de estabelecer uma política de cooperação continental deve-se, na verdade, aos interesses proeminentes em relação às ações subversivas organizadas nos Estados africanos vizinhos (M'BOKOLO, 2011, p.635). Nesse momento forças externas concorreram no processo de independência das colônias africanas e nos acontecimentos políticos posteriores na África Central e Austral: a interferência dos Estados Unidos sobre as metrópoles e Estados nascentes; da União Soviética sobre os movimentos de libertação; e, a pressão da Organização das Nações Unidas (ONU) sobre as políticas segregacionistas sul-africanas.

Os países africanos, com forte concentração do poder na esfera executiva, foram palco de uma série de governos despóticos preocupados em anular os críticos, perseguindo-os e levando-os ao exílio ou a morte. Os golpes de Estado foram: em 1960 e 1965, no Congo-Kinshasa; em 1964, na Zâmbia; em 1966, na República Centro-Africana; em 1967, no Gabão; em 1968, no 
Congo-Brazzaville; em 1973, em Ruanda; em 1975, em São Tomé e Príncipe; e, em 1989 em Comores. Estes enumeram alguns dos Estados da África Central e Austral citados na cobertura geográfica dos boletins. (M'BOKOLO, 2011, p.660).

O fortalecimento do poder executivo vinculado ao partido único não enfraqueceu o poder das chefias tradicionais, já que vários dirigentes originaram-se dessas elites. $O$ enfraquecimento de algumas delas, como o que ocorreu no Congo-Brazzaville, correspondeu ao combate de um tipo de poder local oposto à política que o poder central promovia (M'BOKOLO, 2011, p.664). Nas duas situações, os sítios arqueológicos e históricos estavam envolvidos nas disputas em relação às políticas de gestão patrimonial da memória local.

A década de 1960 marcou uma nova fase da arqueologia a qual influenciou aqueles que trabalhavam no continente africano. A partir das obras de Lewis Binford, nos Estados Unidos, e de David L. Clarke, na Inglaterra, a perspectiva particular e histórica da explicação arqueológica deu lugar a uma perspectiva globalizante, considerando os processos de mudanças das culturas pretéritas que deram origem aos vestígios arqueológicos. Binford, arqueólogo promotor da Nova Arqueologia - New Archaeology - destacava que a cultura é um sistema composto de partes (tecnologia, organização social e ideologia) chamadas subsistemas articuladas de acordo com a relação do homem e o meio-ambiente (TRIGGER, 2004, p.290). A cultura muda, nesta ótica, conforme alterações em algum desses subsistemas ou na relação com o espaço físico.

Nesse momento, os arqueólogos da Nova Arqueologia delinearam uma nova maneira de inscrever a sua disciplina como uma ciência que operava segundo procedimentos definidos, cujos profissionais eram especializados nos métodos de trabalho e na terminologia utilizada e cujas técnicas eram novidades, pois adotaram as inovações da física, da química, da estatística, além das observações etnográficas. A busca por explicações generalizantes para a vida das populações e as mudanças culturais pretéritas foi base para os estudos da antiguidade humana por esta vertente da disciplina (HODDER, 1996, p. 130-1). 
Segundo Shepherd (2002), os posicionamentos dos especialistas da Nova Arqueologia - alguns dos quais teriam uma perspectiva positivista construída no afastamento da sociedade da época - recrudesceu as arqueologias ideologicamente coloniais. Nesses anos, o surgimento de um centro produtor desse conhecimento, como os Estados Unidos, influenciaria a arqueologia realizada na África e sobre a África, dando continuidade a um processo de periferização ou dependência da produção e divulgação do saber arqueológico africano.

Segundo Tilley (1989), outra crítica à corrente da Nova Arqueologia é o posicionamento indiferente dos arqueólogos ao escavar sítios sacralizados exumando ossadas e objetos e dispersando-os pelo mundo. Ao considerar que o estudo do passado do continente era realizado em grande parte por africanistas, que os métodos destrutivos de escavações foram largamente utilizados e que essas escavações resultavam em uma circulação paralela de vestígios arqueológicos valiosos para os colecionadores, podemos considerar que essas metodologias da Nova Arqueologia foram instrumentalizadas para uma apropriação colonial da memória dos povos da região central e austral. (SHEPHERD, 2002, p.192).

Os anos de 1987 e 1993 foram marcados pela crescente participação dos países africanos no cenário da globalização e da presença das empresas multinacionais, explorando uma diversidade de matérias-primas locais. As políticas desenvolvimentistas dos Estados independentes, que variaram entre a opção capitalista ou socialista, dependiam de produtos manufaturados dos países ocidentais, da produção de matérias-primas no setor agrícola e minerador e à sujeição aos empréstimos externos garantidos nas reservas de petróleos e minerais preciosos (M'BOKOLO, 2011, p.641, 643, 645-647).

As mudanças políticas e sociais que ocorrem no final dos anos de 1980 e início da década de 1990 no continente fazem parte do processo histórico que se desenvolveu desde o final da Segunda Guerra Mundial. $O$ reordenamento político e o questionamento da estrutura de produção e divulgação do conhecimento arqueológico por parte dos intelectuais africanos e 
africanistas era cada vez mais visível nos boletins arqueológicos. Trataremos dessa temática ainda neste capítulo.

Essas décadas finais do século $X X$ foram um período que vários Estados africanos adotaram o multipartidarismo assentado na participação política de diferentes setores da sociedade civil para estabelecer um regime pluralista de Estado de direito. Essa transição para a democracia fez-se, inclusive, pelo questionamento do modelo de Estado centralizado por uma opinião pública em formação. Os editoriais dos boletins refletiam essas demandas através das reflexões sobre a Arqueologia Comunitária. A luta pela descolonização e pela plena emancipação política do continente africano realizou-se no terreno da intelectualidade em que os arqueólogos estão inseridos. No entanto, a perseguição aos críticos dos governos, a falta de investimentos na ciência e da proteção do patrimônio natural e arqueológico concorreu para o exílio de muitos intelectuais africanos.

A arqueologia na África e sobre a África não ficou imune às manifestações contra os regimes segregacionistas e a uma maior participação dos arqueólogos africanos nas publicações. Os editoriais dos boletins foram suporte para reflexões e posicionamentos sobre o papel dos arqueólogos africanos e africanistas nesse novo contexto. O momento ainda foi marcado pelo questionamento do cientificismo da Nova Arqueologia. Esse questionamento deu origem a uma nova perspectiva, chamada Arqueologia Pós-Processual, liderada pelo inglês lan Hodder, entre outros, que propõe a relativização nos estudos arqueológicos e o envolvimento dos nativos nos projetos da Arqueologia Comunitária.

Trigger (1984), De Maret (1990), Posnansky (1996) e Shepherd (2002) relatam que as décadas de 1980 e 1990 foram uma época de concentração de estudos arqueológicos sobre o passado recente dos povos africanos. Os arqueólogos da África Central dedicaram-se às escavações de sítios arqueológicos "recentes" relativos à expansão dos povos de língua bantu associados à difusão da metalurgia, ou especificamente, à "história nacional" e dedicaram-se às pesquisas etnoarqueológicas. Podemos citar como exemplo desses estudos algumas das pesquisas publicadas no boletim Nsi sobre a 
metalurgia do ferro e do cobre na República Democrática do Congo (Zaire) RDC - (Nsi, 1987, n.1, p.3-5); no sul do Camarões (Nsi, 1988, n.3, p.15-19); no Gabão (Nsi, 1989, n.6, p.79-96,); e, no Mayombe - uma região que abrange RDC, Angola, República do Congo - Brazzaville e Gabão (Nsi, 1990, n.7, p.1012 e Nsi, 1991, n.8-9, p. 33-40). Além dessas, temos também algumas divulgadas no boletim NA sobre a metalurgia no noroeste do Camarões e na RDC (NA, junho 1990, n.33, p. 2 e 28).

A influência da Arqueologia Pós-Processualista foi essencial no sentido de debater novas possibilidades temáticas e técnicas da pesquisa arqueológica. Esse período foi caracterizado por uma corrente, ramificação do Pós-Processualismo, chamada Arqueologia Pós-Colonial - "Postcolonial Archaeology". Segundo Gosden (2001) e Moro-Abadia (2006), a arqueologia produzida no mundo é chamada pós-colonial ao considerar cronologicamente a concretização das independências dos países africanos no penúltimo quarto do século XX. Porém, quanto aos aspectos ideológicos, ainda apresenta ranços coloniais. A teoria pós-colonial questiona as antigas formas de pensar das disciplinas que eram pilares do pensamento colonial: antropologia e arqueologia.

Ainda, na perspectiva de Gosden (2001), a principal crítica da teoria póscolonial recai sobre a ideia de que a colonização foi imposta sobre os nativos sem considerar que todos, colonizadores e colonizados, têm agência no fomento cultural. Outro ponto a considerar nessa doutrina é a ênfase na cultura e no estudo do processo colonial ao invés de focar em outros aspectos, como por exemplo, o econômico e o político. Um importante expoente dessa teoria é Edward Said, que publicou o livro Orientalism no ano de 1978, entre outros trabalhos, conhecido pelo seu profundo envolvimento ideológico com a "causa Palestina". A teoria pós-colonial, expressa nos trabalhos de Said e de outros citados por Gosden (2001) e Moro-Abadia (2006) - Michael Foucault, Jacques Derrida, Gayatri Spivak e Homi Bhabha- apresenta algumas tendências temáticas, como: a mentalidade colonial, a herança colonial em diferentes aspectos, a construção das nações independentes, entre outros. A análise dos discursos textuais, por esses autores, pautou-se no estudo das formas como as verdades foram construídas, os significados dos silêncios, a multiplicidade ou a 
ambiguidade dos temas nas fontes documentais (Moro-Abadia, 2006). É nesse sentido que a nossa dissertação de mestrado transcorre a análise do corpus documental.

Uma forte tendência na arqueologia pós-processual, das décadas de 1980 e 1990, foi à denúncia de que a disciplina foi e continuava sendo legitimadora do colonialismo e do imperialismo. Assim, a disciplina necessitava de uma postura ética e politica a favor dos povos colonizados (MORO-ABADIA, 2006). Desse modo, a Arqueologia pós-colonial, ramificação do PósProcessualismo, apresentou-se como uma corrente de pensamento politicamente engajada em relação aos direitos dos povos nativos sobre o seu passado. Nesse ponto de vista, foi caracterizada por uma nova relação dos especialistas com a comunidade nativa, expressada pelos métodos e objetivos da pesquisa, pelas novas formas de divulgação dos resultados e pelas mudanças nas leis de proteção do patrimônio arqueológico. A fim de comprovar essa preocupação dos arqueólogos sobre este último item, temos a legislação Environment Conservation Act (1989), da África do Sul, discutida nos editoriais do TSAAB. Estes também abordam, como um parâmetro, as legislações aprovadas nos Estados Unidos - Native American Graves Protection and Repatriation Act, datada de 1990 - e na Austrália - Aboriginal and Torres Strait Islander Heritage Protection Amendment Act, datada de 1987.

A questão que se coloca nessa nova relação entre arqueólogos e a comunidade local é a importância da multivocalidade dos nativos, o controle sobre as versões do passado local e sobre a custódia do material arqueológico e das ossadas exumadas nos sítios (GOSDEN, 2001; HODDER, 2003). Uma das imagens difundidas nesse período nos editoriais e nos congressos de arqueologia africana, como por exemplo, o World Archaeological Congress do ano de 1986, é a do especialista engajado politicamente em construir o passado local e preocupado com a divulgação dos resultados para a comunidade. Entretanto, esses arqueólogos africanos e africanistas trabalharam em meio a problemas de ordem geral.

Os primeiros anos da década de 1990 foram marcados fortemente pela instabilidade política, econômica e social que funcionava como cenário na 
constituição da ciência arqueológica. O endividamento econômico crescente e o surto pandêmico da AIDS, que matou pessoas em idade produtiva, geraram uma crise econômica nos países africanos recém-independentes e na África do Sul. Posnansky apud Shepherd (2002) chama a situação de "colapso da arqueologia da África Ocidental' que pode ser considerada para o caso das duas regiões estudadas.

Se a primeira metade do século XX, até a década de 1970 foi tida como uma "era da esperança e orgulho" para os arqueólogos, o final dos anos 1980 e início dos anos 1990 foi considerada a "era de pessimismo" ou a "era da desilusão" (KAREGA-MUNENE e SCHMIDT, 2010). De outro modo, Shepherd (2002, p.200), indica que o subdesenvolvimento das arqueologias locais devese menos ao colapso econômico e mais à "falta de controle dos arqueólogos africanos de suas agendas de pesquisa e prioridades." ${ }^{19}$ Podemos aprofundar essa crítica de Shepherd (2002) recorrendo a análise de Schmidt (2009) a qual procura entender como a herança colonial ainda influencia a arqueologia póscolonial da África. Esses vestígios são explícitos na marginalização dos africanos e concentração de africanistas nas publicações científicas, na valorização das fontes coloniais e na pouca abordagem dos temas que desafiam paradigmas (SCHMIDT, 2009; BAGODO, 2004).

Dessa forma, a Arqueologia Pós-Colonial africana apresenta embates ideológicos entre arqueólogos africanos e africanistas que devem ser considerados na análise do corpus documental. A designação pós-colonial, portanto, não se refere a um período histórico da Arqueologia da África e sobre a África, mas a todo um conjunto de metodologias e ideologias concorrentes que repensam o papel do arqueólogo no final do século XX.

\footnotetext{
${ }^{19}$ Crucially, it has also come about as the result of the lack of control by African archaeologists of research agendas and priorities. (Shepherd, 2002, p.200)
} 


\section{Mapa 3 - Maiores sítios arqueológicos da África}

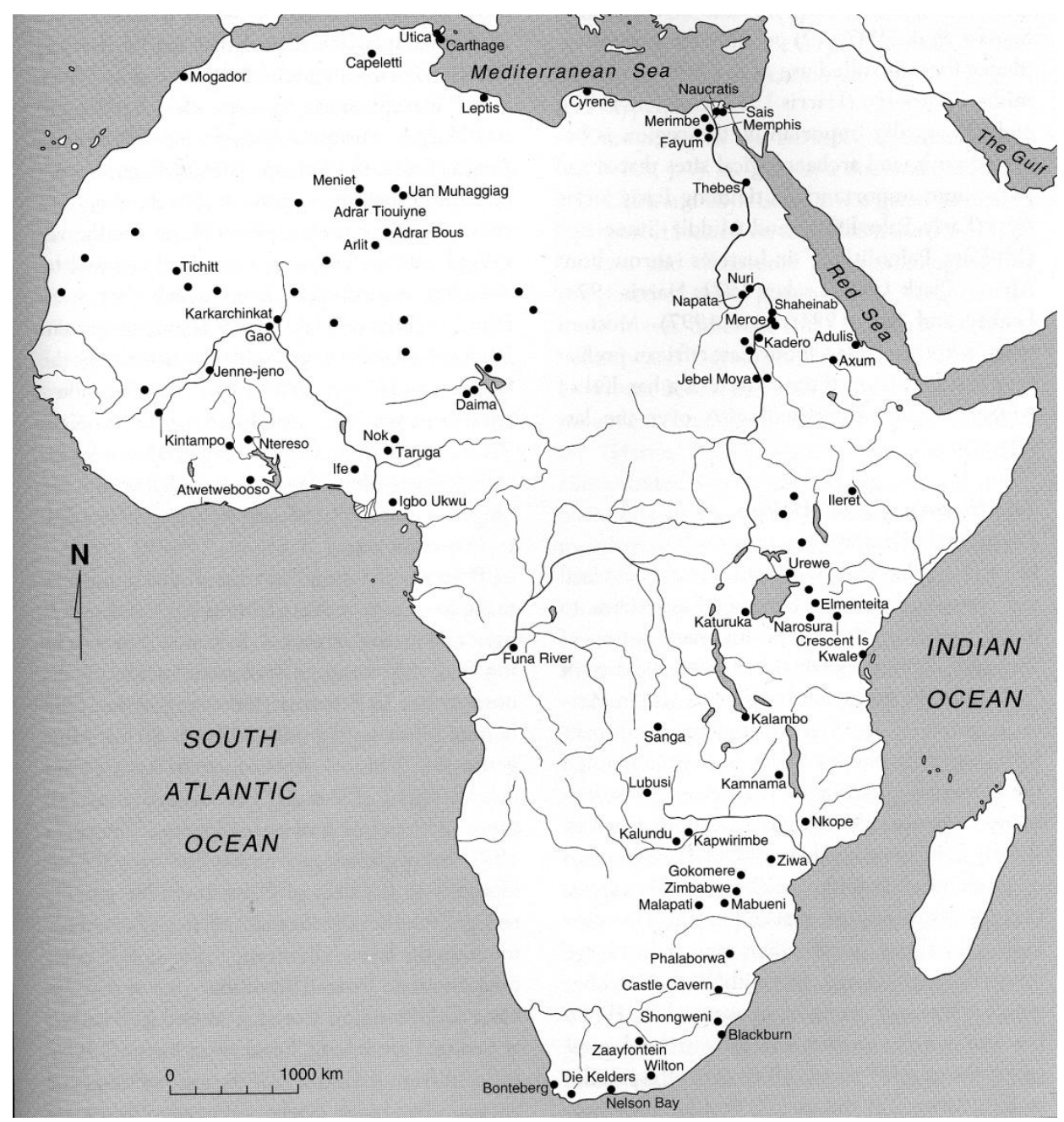

Fonte: MURRAY (2001, p.17)

\section{ÁFRICA CENTRAL}

O primeiro número do boletim TSAAB, datado de dezembro de 1945, apresentou o subtítulo: Da África Central ao Cabo ${ }^{20}$. Décadas depois, em 1987, o primeiro editorial do Nsi divulgou a definição da sua abrangência: "A área geográfica abrange o conjunto espacial dos locutores bantu da África Central, Oriental e Austral $[\ldots]^{321}$. Por sua vez, o boletim NA abarca todo o continente como a sua cobertura geográfica, com exceção do Egito e Norte da África. Partimos da demarcação regional realizada pelos próprios boletins para reconstituir a história da arqueologia da África Central e Austral.

\footnotetext{
${ }^{20}$ From Central Africa to the Cape. (TSAAB, dezembro 1945, vol.1, n.1, p.1)

21 L'aire géographique qu'il couvre embrasse l'ensemble de l'espace des locuteurs bantu d'Afrique Centrale, Orientale et Méridionale [...] (Nsi, 1987, n.1, p.1)
} 
A África Central também é nomeada África Equatorial do Oeste (M'BOKOLO, 2010, p.229). Segundo Adedeji (2010, p.490), no ano de 1960, a Comissão Econômica para a África (CEA) da Organização das Nações Unidas (ONU) dividiu o continente em sub-regiões em prol da integração regional e como uma etapa para a integração continental e nomeou essas regiões como África Oriental e Austral, Ocidental, Central e do Norte. Para fins de padronização da terminologia desta dissertação usaremos a forma África Central adotada nos editoriais dos boletins analisados.

Conforme aponta o especialista em arqueologia dessa região Pierre De Maret (1990), a África Central compreende Angola, República Democrática do Congo (Ex-Zaire), Camarões, Gabão, República Centro-Africana, República do Congo (capital Brazzaville) e Guiné Equatorial. Já, Hermens (2010), responsável por um dos dois capítulos sobre Pré-História da África Central da coleção História Geral da África, considera que a região é formada por Zaire antigo nome da República Democrática do Congo, República Centro-Africana, República do Congo, Gabão, Camarões, e em parte, Angola, Ruanda e Burundi (cf. mapa quatro).

\section{Mapa 4 - Foto de satélite da África Central}

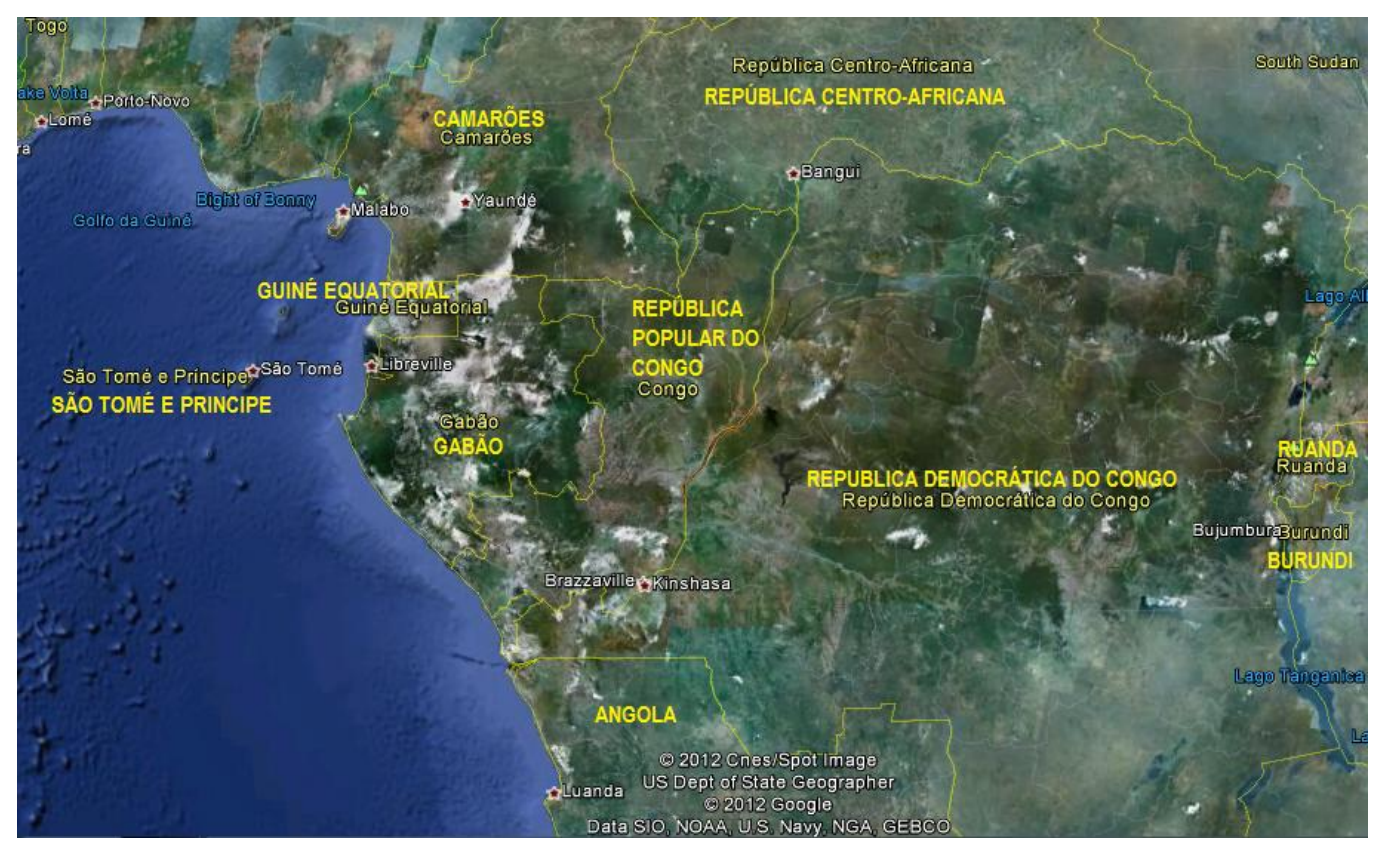

Fonte: GOOGLE EARTH. Acesso em 14/10/2012. 
Apesar dessas indicações, a delimitação regional não se dá pelas divisas políticas dos países, mas se define por outros fatores. Segundo De Maret (1990), a região é circunscrita pela bacia hidrográfica do Rio Congo/Zaire, parte da bacia do Rio Níger, do Nilo e do Zambezi. Nessa perspectiva, também seria composta de Ruanda, Burundi e Zâmbia e, ao norte, da parte sul do Chade. A bacia hidrográfica do Rio Congo/Zaire é composta por uma depressão geográfica de 750.000 quilômetros quadrados que, ao norte e ao sul, apresenta as planícies de Uele, Kasai e Shaba com cobertura florestal e, a leste, montanhas, grandes lagos e savanas.

O Rio Congo/Zaire atinge uma área de 3.684 .000 quilômetros quadrados. Segundo Schmalenbach (1988, p.227), esse imenso curso d'água e seus tributários, aliados à vegetação, exercem grande influência sobre a vida dos povos silvícolas e das savanas, afinal, são numerosos e diversos os materiais oriundos do solo, da flora e da fauna para a produção de artefatos. Em que pese à ênfase dada pelo autor, que analisa a arte africana, à influência dos recursos naturais sobre esses povos locais, no que se refere aos estudos das culturas materiais na África Central, geram dados essenciais para os especialistas da Etnoarqueologia e da Arqueologia Comunitária.

Outro fator para estabelecer a delimitação da região é o aspecto cultural. De acordo com a definição dada pelo editorial do Nsi de 1987, já citado, a região é um conjunto espacial de locutores de língua bantu. Nesse sentido, o que dá unidade à África Central, ou de modo mais generalizante, unifica à África subsaariana, é o processo histórico das migrações dos povos falantes das línguas bantu que ocorreu entre dois mil anos a quatro mil anos atrás. Nesse processo esses povos dispersaram-se do território hoje conhecido como Camarões, em direção ao sul do continente - verificar o mapa cinco. A partir destas migrações, os estudiosos consideram que ocorreu uma difusão das práticas dos assentamentos, da metalurgia, da cerâmica e da agricultura nessa parte da África (VANSINA, 1999, p.10; PHILLIPSON, 2005, p.201; POSNANSKY, 2010, p. 592). 


\section{Mapa 5 - Um dos modelos de origem e das rotas expansão bantu.}

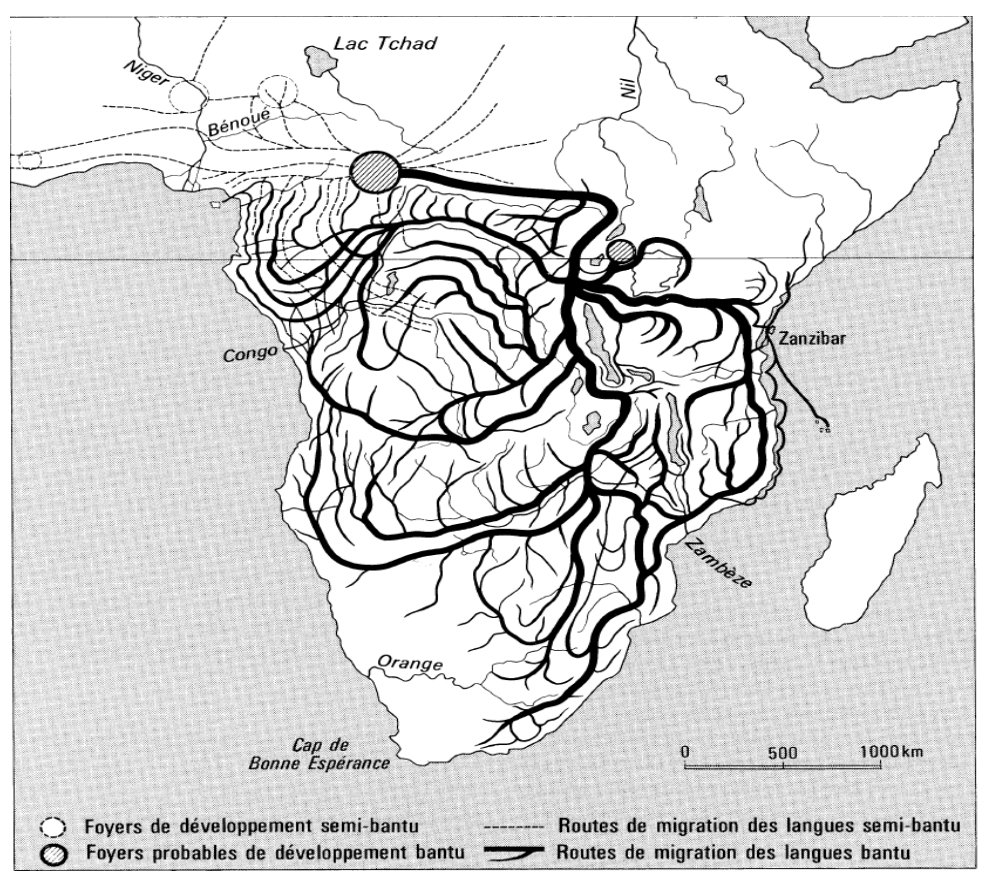

Fonte: CHRÉTIEN, 1985, p.54.

Phillipson (2005, p.4), ao afirmar a importância da análise das tradições orais relacionadas às memórias dos reinos que ali se constituíram, reconhece que as fronteiras culturais no continente africano não são claramente definidas. Isso pode ser notado pela distribuição da cultura material a qual não coincide necessariamente com a caracterização de determinados estilos de vida ou de instituições políticas e sociais. Assim, consideramos que a tentativa da demarcação da região deve atentar-se para além do estudo dos estilos de vida e do manejo dos recursos naturais, mirando inúmeras possibilidades de critérios para delimitar a África Central.

Conforme De Maret (1990) e Connah (2001), essa é a parte do continente que, comparada às regiões com grandes estruturas urbanas antigas como o Mali, a Nigéria na África Ocidental, o Grande Zimbábue no sul do continente ou ao Vale do Nilo, foi realizada um número reduzido de pesquisas arqueológicas, como podemos verificar no mapa seis abaixo. Neste ponto, abordaremos a História da Arqueologia da África Central para melhor interpretar os editoriais selecionados, os quais apresentam em seus discursos as especificidades e as vicissitudes do trabalho na região e que geraram o aparente desconhecimento do seu passado. 


\section{Mapa 6 - Alguns sítios arqueológicos da África Central}

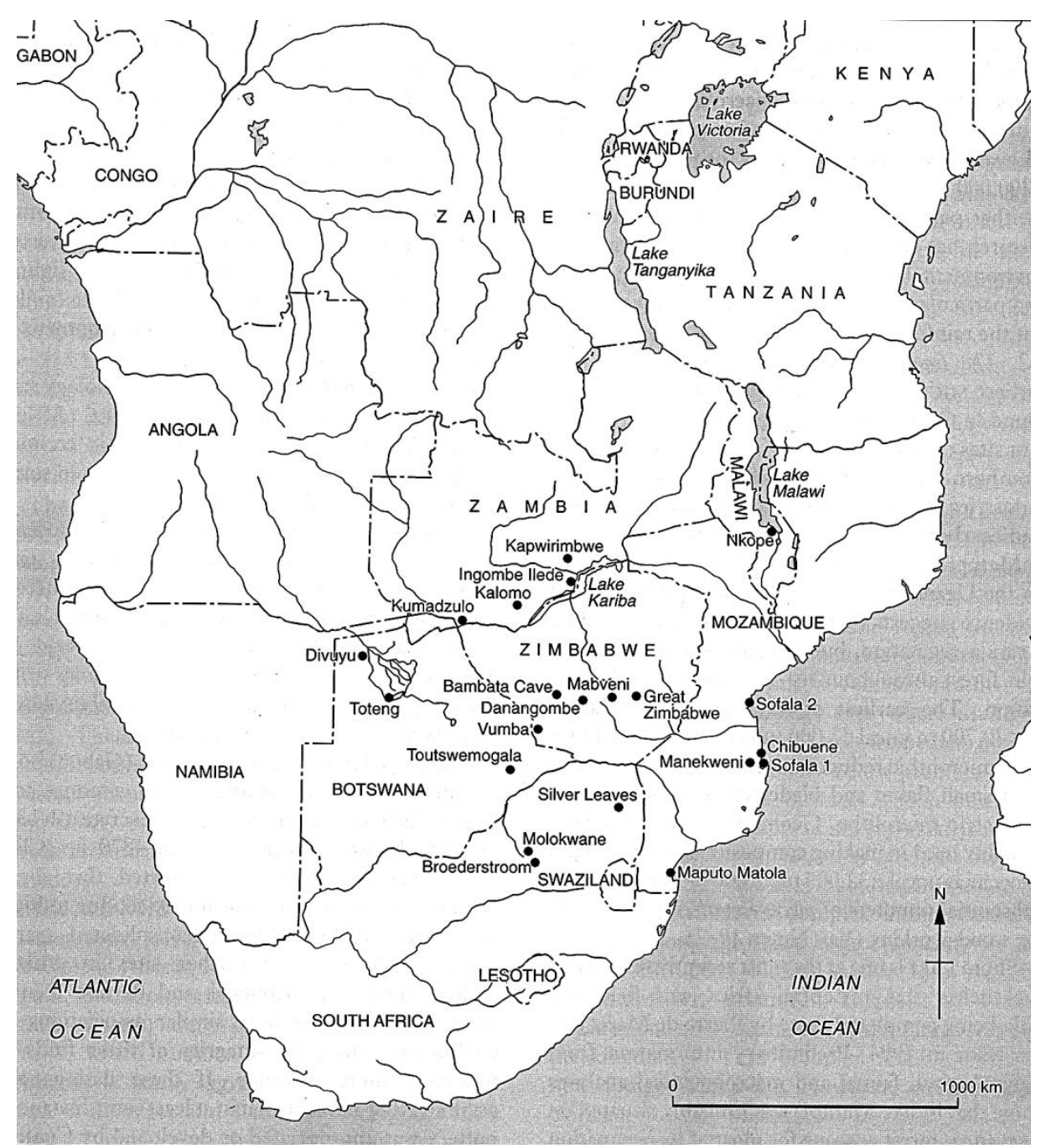

Fonte: SHAW e JAMESON (2002, p.29)

Segundo Pierre De Maret (1990, p.109), a partir da Convenção de Berlim em que se deu a chamada Partilha da África entre as potências europeias na década de 1880, houve a dispersão do esforço da pesquisa arqueológica entre diferentes países e a restrição da publicação dos seus resultados em revistas de circulação limitada. Estes fatores podem explicar a percepção dos poucos estudos realizados na região central que, mesmo assim, são relevantes e constituem a história da arqueologia desta região continental.

De Maret (1990) dividiu a História da Arqueologia da África Central em quatro fases. 
A primeira fase ocorreu no período compreendido entre a segunda metade do século XIX e a Primeira Guerra Mundial. É caracterizada pela condução das pesquisas pré-históricas na Europa e na África Central pautada pelas teorias evolucionistas. Essas pesquisas teriam como referência de civilização o mundo clássico e o Egito. As descobertas arqueológicas eram realizadas por exploradores, missionários e funcionários do governo colonial. De acordo com Gabel (1985, p.247), a bacia do Rio Congo foi explorada por amadores em busca de ferramentas líticas. Em 1882, o capitão Hore, fundador da London Missionary Society, localizou pedras perfuradas nas proximidades do Lago Tanganika, entre RDC, Tanzânia, Burundi e Zâmbia. Entre os anos de 1883 e 1884, o comandante C. Zboinsky, colaborador do Rei Leopoldo II, encontrou ferramentas paleolíticas no Baixo Congo. Nessa mesma década, o naturalista Georg Schweinfurth descobriu machados de pedra polida na região de Ituri, nordeste da RDC.

Os relatos dessas descobertas e o modelo explicativo evolucionista aplicado na arqueologia colonial desta região geraram, precocemente, terminologias próprias denotadas já a partir do título do primeiro livro exclusivo sobre a História da África subsaariana, A ldade da Pedra no Congo (STAINIER, 1899 apud DE MARET,1990). Essa primeira síntese da antiguidade da África Central baseava-se, sobretudo, nas descobertas efetuadas nos sítios do Baixo Congo, do Katanga (Shaba) e da área central do Congo (GABEL, 1985).

A segunda fase da pesquisa arqueológica na África Central engloba o período entre guerras, sendo apontada por um marco distinto no desenvolvimento da arqueologia local. Ocorreu o estabelecimento das técnicas de escavação, das tipologias e terminologias em âmbito regional e interregional com foco na classificação e nas cronologias (GABEL, 1985, p.251). De Maret (1990) e Gabel (1985) comentam sobre o método de escavação proposto por Jean Colette, em 1925, para solucionar problemas de datação na interpretação do registro arqueológico no sítio Kalina Point, em Leopoldville, Congo-Kinshasa. A inovação do pesquisador deve-se ao fato de que, até esse momento, a pesquisa arqueológica resumia-se na coleta e descrição dos achados na superfície. O pesquisador empregou termos locais, propôs a análise de dados estatísticos e tentou situar a pré-história da África Central em 
face da Europa, mesmo que seu trabalho tenha tido pouco reconhecimento entre os pesquisadores de sua época.

Para Gabel (1985), as pesquisas arqueológicas da África Central concentravam-se mais no período Stone Age do que no Iron Age devido:

\begin{abstract}
O período Stone Age, por outro lado, tinha alguns pontos reais de comparabilidade com a antiga sequência histórica euro-asiática, tornando inútil lidar com os africanos recentes, exceto, talvez, os caçadores-coletores que ainda restavam que eram vistos como um tipo de laboratório para comparação e reconstrução. (GABEL, 1985, p.251 - tradução livre) $)^{22}$
\end{abstract}

Outros pesquisadores foram importantes nessa fase. Contemporâneo a Colette, Oswald Menghin, analisando um conjunto de líticos, descreveu a indústria Tumbakultur. Posteriormente, T.P. O’Brien, em 1937, iria empregar o termo "Tumbian" para definir os conjuntos estudados por ele na Uganda e, em 1945, Leakey e Owen iriam adotá-lo para os implementos do Quênia. "Tumbian" foi substituído por muitos pesquisadores por "Sangoan". Na década de 1930 ocorreu a atuação de Francis Cabu, no Congo, que introduziu os termos "Lupemban" e "Tshitolian" para as indústrias do período Stone Age posteriores à Tumbian/Sangoan. Ainda nesse momento, o Professor Lacroix e Félix Eboué - nascido na Guiana francesa e primeiro negro administrador colonial - identificaram ferramentas líticas na República Centro-Africana (GABEL, 1985, p.256, 259).

Nesse momento, projetou-se a pesquisa pioneira de coleta das tradições orais fomentada na região ao sul do Lago Chade na África Ocidental pelos franceses Marcel Griaule e Jean-Paul Lebeuf, visando à compreensão do passado das populações. Da mesma forma, as pesquisas arqueológicas na África Central passaram a questionar os registros históricos e etnográficos cujas interpretações eram oriundas de modelos explicativos evolucionistas (DE MARET, 1990). No entanto, consideremos outras motivações que permitiram o avanço de estudos arqueológicos.

\footnotetext{
${ }^{22}$ Stone Age prehistory, on the other hand, had some real points of comparability with the Eurasian early prehistoric sequence while making it unnecessary to deal with recent Africans, other than perhaps those remnant hunter-gatherers who were seen to represent a kind of laboratory case for comparison and reconstruction. (GABEL, 1985, p.251)
} 
Sabe-se que em Angola, para não perdermos o referencial da África Central, a Companhia de Diamantes de Angola - DIAMANG - ficou conhecida pelas descobertas arqueológicas realizadas ocasionalmente em razão do trabalho de remoção de grandes volumes de terra durante o período colonial. Essa organização mantinha o Museu do Dundu, fundado em 1937, com coleções de artefatos extraídos das minas de diamantes (AREIA, 2007, p.157). O chefe do departamento de prospecção, J. Janmart redigiu textos os quais mencionavam o resultado das suas pesquisas geológicas e arqueológicas em Luanda. Escreveu, inclusive, em colaboração com o arqueólogo francês Abbé Henri Breuil, em 1950 (GABEL, 1985, p.256).

Por fim, ainda na segunda fase da arqueologia centro-africana, verificase uma crescente profissionalização e institucionalização da pesquisa arqueológica com o financiamento por parte dos governos francês e belga, ainda que grande parte dela fosse realizada sobre as coleções museológicas (DE MARET, 1990, p.122).

A terceira fase abrange o período compreendido entre a Segunda Guerra Mundial e a independência dos países africanos. Nas décadas de 1950 e 1960, ocorreu, segundo Robertshaw (1990) e Gabel (1985), um grande desenvolvimento da arqueologia africana devido ao aperfeiçoamento dos métodos de datação através do radiocarbono e da acuidade que passam a ter os estudos de adaptação dos seres humanos ao meio ambiente.

Connah (1996) cita a realização de importantes congressos da comunidade arqueológica nessa fase, desde o Primeiro Congresso Panafricano de Estudos do Quartenário e da Pré-História, em 1947, Nairobi, organizado por Louis e Mary Leakey até os seis congressos de mesmo nome subtraído da expressão Quaternário, os quais se sucederam até 1971, em vários lugares do continente africano. Dois desses seis encontros científicos foram sediados na África Central, nas cidades de Léopoldville - atual Kinshasa - na RDC e de Livingstone, na Zâmbia.

Conforme De Maret (1990), os eixos dos primeiros congressos centraram-se nas discussões sobre a terminologia das divisões temporais, as tipologias empregadas nas coleções e a ausência de publicação dos 
resultados. A revolução dos métodos de datação através do radiocarbono também foi focada e possibilitou novos questionamentos sobre as origens das práticas da metalurgia e da agricultura na África subsaariana. Em sua participação, Mortelmans expôs a ideia da introdução do ferro na África subsaariana à chegada dos povos falantes de línguas bantu. Esse pressuposto influencia ainda, na atualidade, as pesquisas arqueológicas na África Central e Austral, porque originou um modelo explicativo paradigmático ligado à pesquisa linguística (cf. mapa cinco). Ainda segundo De Maret (1990):

Hiernaux teve primeiro a ideia, em 1959, no Congresso Pan-Africano
em Léopoldville, de ligar este conjunto cerâmico [de Ruanda e
Burundi] com a expansão enorme e relativamente recente dos grupos
linguísticos Bantu documentados por Greenberg (1949). Esta ideia já
estava no ar, como foi mencionado acima, Mortelmans (1957b) tinha
atribuído a introdução da metalurgia aos Bantu. (DE MARET, 1990,
p.128) ${ }^{23}$

O autor relembra que, desde meados do século $X X$, o problema da origem e difusão das línguas bantu, da metalurgia, da cerâmica e das técnicas de produção de alimentos na África subsaariana norteiam as pesquisas arqueológicas, as quais se concentram no território de Camarões. A década de 1950 distinguiu-se pelas pesquisas de L. Cahen, J. Lepersonne e G. Mortelmans que se debruçaram sobre a arqueologia do Congo, J. de Heinzelin de Braucourt, escavador da região de Ishango e J. Nenquin e Hiernaux que escavaram um grande cemitério no Sanga, ambas regiões pertencentes ao RDC (GABEL, 1985). O interesse dos arqueólogos por um passado mais recente de povos nativos e pela pesquisa das tradições orais da África Central também é contemporâneo ao movimento pelas independências dos países africanos. Esses aspectos caracterizam a terceira fase da História da Arqueologia na África Central profundamente marcada pelos processos de independência política.

As colônias da África Central que passaram pelo processo de independência são citadas nos editoriais TSAAB, N.A. e Nsi como limites da cobertura espacial das publicações. Em 1960, dezoito colônias tornaram-se

\footnotetext{
${ }^{23}$ Hiernaux (1962) first had the idea, in 1959, at the Pan-African Congress at Léopoldville, of linking this pottery with the enormous and relatively recent expansion of the Bantu linguistic group documented by Greenberg (1949). This idea was already in the air, for as has been mentioned above, Mortelmans (1957b) had attributed the introduction of metallurgy to the Bantu. (DE MARET, 1990, p.128)
} 
independentes, entre elas, Zaire - ex-Congo belga, República do Congo (exCongo Brazzaville), Gabão, Camarões e República Centro-Africana (exUbangui-Chari). Logo após, em ordem cronológica, tornaram-se independentes: Ruanda (1962); Zâmbia (1964, ex-Rodésia do Norte); Lesoto (1966, ex-Basutolândia); Guiné Equatorial (1968, ex-Guiné Espanhola); Angola, Comores - exceto a ilha Mayotte - e São Tomé e Príncipe (1975); e, Zimbábue (1980, ex-Rodésia do Sul) (M'BOKOLO, 2011).

A quarta fase, de acordo com De Maret (1990), foi marcada pela formação e pela consolidação dos Estados nacionais da África Central com a participação da pesquisa arqueológica. Shepherd (2002) relata o período da seguinte forma:

\begin{abstract}
Em muitos países africanos, a sensação de otimismo que acompanhou a independência e as duas décadas de desenvolvimento dos anos 1960 e 1970, deu lugar ao endividamento crescente e ao desânimo na década de 1980 e, na década de 1990, a uma sensação de crise efetiva. [...] Para a prática da arqueologia na África [a situação] foi sentida como uma crise de recursos. Depois de um início promissor nas décadas de 1960 e 1970, a última década assistiu ao encolhimento das arqueologias realizadas por africanos. (SHEPHERD, 2002, p.199 - tradução livre) ${ }^{24}$
\end{abstract}

A crise econômica e a turbulência dos regimes políticos locais impactaram fortemente a trajetória da arqueologia africana que vinha sendo construída concomitante às lutas pelas independências. A pesquisa arqueológica reorientou-se na direção da "pré-história recente" e dos problemas relacionados à "história nacional", para usar os termos de Trigger (1984, p.363), como: origem dos Estados, desenvolvimento do comércio, evolução das instituições sociais e econômicas, relações entre grupos étnicos e entre esses e os Estados modernos africanos, interesse em escavar sítios arqueológicos e históricos famosos. Esses estudos sobre o passado recente dos Estados nacionais recém-formados foram nomeados de Arqueologia Nacionalista (TRIGGER, 1984).

\footnotetext{
${ }^{24}$ For many African countries, the sense of optimism that accompanied independence and the two development decades of the 1960s and 1970s gave way to increasing indebtedness and despondency in the 1980s and, in the 1990s, a sense of active crisis. [...] For the practice of archaeology in Africa this has been felt as a crisis of resources. After a hopeful start in the 1960s and 1970s, the past decade has seen the shrinking of indigenous archaeologies in Africa. (SHEPHERD, 2002, p.199)
} 
A arqueologia africana das décadas de 1980 e 1990, chamada de subdesenvolvida por Shepherd (2002) e colapsada por Posnansky (1996), apresentou matizes a serem consideradas na análise dos editoriais selecionados, como podemos constatar no editorial do Nsi escrito em 1987 por Ba-Meya, diretor de pesquisa do CICIBA:

\begin{abstract}
Nesta segunda entrega anual do boletim várias inovações ilustram bem a dimensão mundial, o impacto internacional e regional, agora adquirido pelo Nsi. [...] Uma cobertura do trabalho cada vez mais importante dos estados-membros [do CICIBA] se materializa nesse segundo número do Nsi através dos relatórios provenientes de Angola, da República Centro-Africana, do Gabão, da Guiné Equatorial e da Zâmbia. (Nsi, 1987, n.2, p.3 - grifos nossos, tradução livre) ${ }^{25}$
\end{abstract}

Nesse trecho, o editor não assina com o nome próprio, mas sim com o de sua posição profissional no boletim - Le directeur de la recherche. Ele transmitiu uma sensação de otimismo, bem diferente da perspectiva negativa da pesquisa arqueológica de Shepherd (2002) e Posnansky (1996). Essa impressão otimista possivelmente deve-se ao lançamento do próprio boletim poucos meses antes e à necessidade dos editores de criar uma empatia com o arqueólogo-leitor da nova publicação. Uma análise mais aprofundada sobre o Nsi é uma oportunidade para compreender as nuances da história da arqueologia da África Central nas décadas finais do século XX.

O boletim Nsi foi lançado no ano de 1987, como uma publicação do Departamento de Arqueologia do Centro Internacional das Civilizações Bantu (CICIBA). Este, por sua vez, foi criado por iniciativa do presidente do Gabão, Omar Bongo, e ratificado em uma convenção de ministros da cultura da África Central em 1983 (TOURNEUX, 1983, p.95). Abordaremos com mais especificidade esse boletim no capítulo seis.

Nesse momento, analisaremos o papel do presidente-ditador Omar Bongo do Gabão na constituição de uma instituição que publica um boletim de arqueologia centro-africana até o ano de 1992. Em 1993, o Nsi foi incorporado ao NA.

\footnotetext{
${ }^{25}$ Dans cette seconde livraison annuelle du bulletin, plusieurs innovations illustrent bien la dimension mondiale, l'impact international et régional désormais acquis par NSI. [...] Une couverture de plus en plus importante du travail des états-membres se matérialise dans ce seconde numéro de NSI par les rapports en provenance d'Angola, de Centrafrique, du Gabon, de Guinée Equatoriale et de Zambie. (Nsi, 1987, n.2, p.3)
} 
Em 1960, o Gabão tornou-se um estado independente da França que o mantinha como uma colônia da África Equatorial Francesa (DIOP, 2010). No ano seguinte, Léon Mba foi eleito Presidente da República deste país. Com sua morte, devido a uma doença, Albert Bernard Bongo sucedeu-o na função em 28 de novembro em 1967 - ver figura um - e instaurou um regime de partido único e de eliminação dos adversários políticos, como o embaixador Germain Mba (REED, 1987, p.298). Em 1973, o presidente converteu-se ao islamismo e mudou o seu nome para El Hadj Omar Bongo.

Figura 1 - Omar Bongo, s.d.

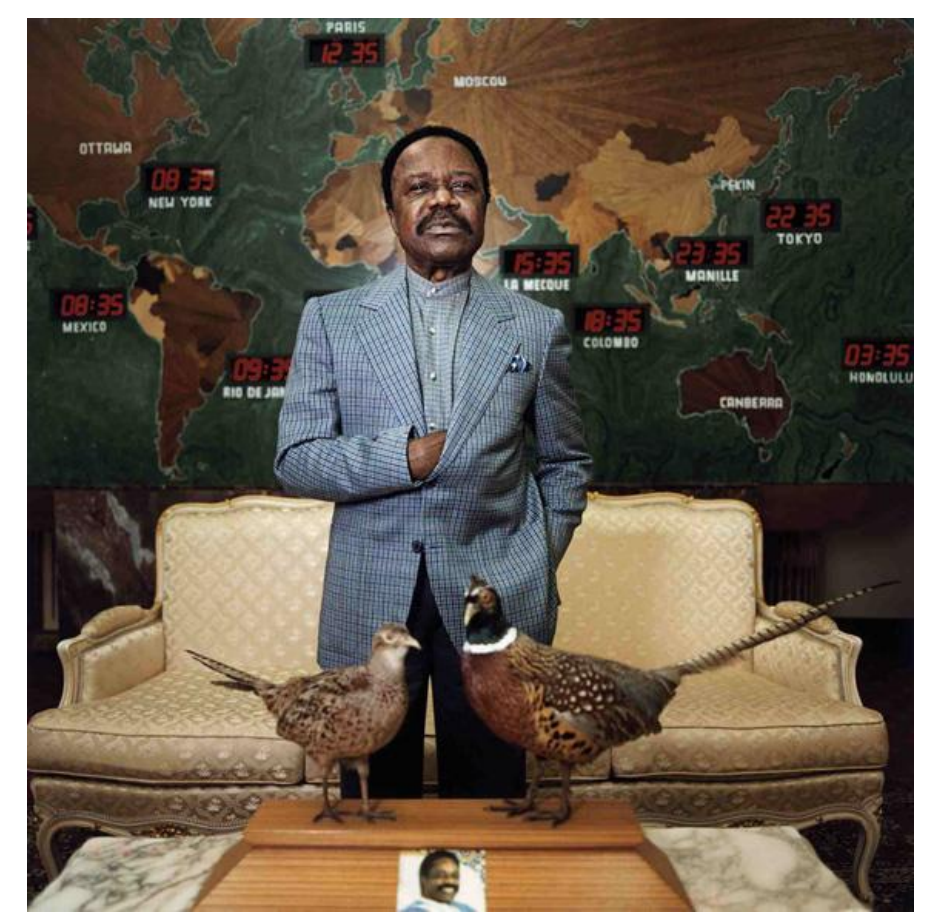

Fonte: LUDOVICCAREME.COM. Créditos: Ludovic Carème para o jornal Liberátion.

Ele governou o Gabão entre os anos de 1967 a 2009, até a sua morte em 07 de junho de 2009. O seu filho Ali Bongo, sucedeu-o como presidente eleito no mesmo ano. Ngolet (2000, p.57) e Reed (1987) afirmam que sua longevidade política ocorreu, devido ao apoio da antiga metrópole, a França, manifestado em uma base militar permanente no Gabão, além do seu auxílio na criação do Serviço Secreto Gabonês (CEDOC). Outros fatores colaboraram para a permanência de Bongo no poder: a força militar, a utilização dos recursos econômicos para conseguir apoio, uma enorme máquina estatal e 0 controle sobre os aspectos simbólicos da sociedade gabonesa (DECALO, 1989). Sobre este último fator, Ngolet (2000, p. 58) deduz: 
Na memória coletiva dos gaboneses, Bongo era conhecido como um membro do grupo étnico Bateke, que alcançou o reconhecimento através de seu rei, Makoko (Onko), que assinou um tratado com Pierre Savorgman de Brazza em 1883. Mas, os Bateke são percebidos pela população como sendo os Pigmeus (Babongo ou Tswa), e, portanto, considerado como um povo atrasado e primitivo. Sendo um homem pequeno, Omar Bongo reforçou esta visão popular. [...] É neste quadro ideológico que os camponeses encontraram os sinais, os símbolos e os códigos que explicam a ascensão de Bongo ao poder. Para eles, era simplesmente a continuação da dominação ideológica dos Bantu pelo Pigmeu [Bongo]. Através de sua afiliação com o Tswa, Bongo foi percebido como um indivíduo místico, um homem capaz de ver o invisível e detectar a indetectável, um ser providencial. Tradicionalmente, apenas um indivíduo desta natureza poderia governar e a liderança de Bongo foi facilmente aceita. (NGOLET, 2000, p.58-9 - tradução livre) $)^{26}$

Nesse sentido, Omar Bongo movimentou os aparatos econômicos, militares e simbólicos para manter-se no poder por 42 anos. O aparato simbólico foi analisado por Ngolet (2000) em uma perspectiva antropológica, conforme a citação anterior, que aponta para a tentativa do líder de estabelecer uma ligação dele mesmo com o Rei Makoko, herói mítico entre os pigmeus e os Bantu, grupo dominante. Essa mobilização simbólica atrela-se a sua percepção à respeito da ameaça da dispersão dos poderes "tribais" e a necessária centralização do poder, nele, assentada em uma identidade Bantu homogeneizante (REED, 1987; SCHOENBRUN, 2001).

A "homogeneidade" linguística bantu foi questionada desde 1862 por Wilhelm H.I. Bleek, que cunhou o termo Bâ-ntu para as línguas faladas na África Austral, exceto pelos povos Bushman e Hottentot (SCHOENBRUN, 2001, p. 2). Essa questão, abordada por outros especialistas, entre eles os arqueólogos, originou o paradigma explicativo no qual os povos bantu, entre dois e quatro mil anos atrás, onde hoje é o território de Camarões, avançaram como colonizadores sobre regiões desconhecidas do leste e sul da África,

\footnotetext{
${ }^{26}$ In the Gabonese people's collective memory, Bongo was known as a member of the Bateke ethnic group, which achieved recognition through their king, Makoko (Onko), who signed a treaty with Pierre Savorgman de Brazza in 1883. But the Bateke are perceived by the populace as being Pygmies (Babongo or Tswa), and thus considered a backward and primitive people. A small man himself, Omar Bongo reinforced this popular view. [...] It is in this ideological framework that the Gabonese peasantry found signs, symbols, and codes explaining Bong's rise to power. For them, ist was simply a continuation of the ideological domination of the Bantu by the Pygmy. Through his affiliation with the Tswa, Bongo was perceived as a mystical individual, a man capable of seeing the invisible and detecting the undetectable, a providential being. Traditionally, only an individual of this nature could rule, and Bongo's leadership was easily accepted. (Ngolet, 2000, p.58-9)
} 
levando seus conhecimentos sobre agricultura, metalurgia, além da sua "genética" e "homogeneidade linguística" (cf. mapa cinco). Esse debate, que até o final do século XIX, era realizado apenas por linguistas e etnólogos, adentrou o campo da política ao longo do século XX. Segundo Schoenbrun (2001):

Esta presunção [da expansão linguística bantu] era desejada por nacionalistas românticos e colonialistas que viram a raça, a cultura e a linguagem como as diferentes facetas das identidades nacionais unitárias dispostas hierarquicamente. (SCHOENBRUN, 2001, p. 2) ${ }^{27}$

Assim, depreende-se que esse paradigma explicativo da expansão bantu e da comunidade identitária Bantu - "speech community" - daí gerada, foram instrumentalizados pelos regimes colonialistas e nacionalistas. O governo de Omar Bongo, pretensiosamente, enquadra-se nesse último, apesar do explicito apoio da França ao ditador (REED, 1987). Portanto, a idealização do Centre International des Civilizations Bantu (CICIBA), na perspectiva do presidente do Gabão estava relacionada a essa instrumentalização da identidade homogeneizante bantu em contraposição à fragmentação do poder pelas pequenas chefias.

O CICIBA foi uma instituição científica criada por sua iniciativa, em 1983, tendo como sede Libreville, capital do Gabão, e aprovada pela Primeira Conferência de Ministros da Cultura da Zona Bantu, realizada na mesma cidade, entre os dias 5 a 9 de julho de 1982. Nessa reunião participaram os representantes do Gabão, Angola, Burundi, Congo (República do), Guiné Equatorial, Ruanda, São Tomé e Príncipe e Zaire (República Democrática do Congo). Schoenbrun (2001, p.4) reproduz um trecho do pronunciamento de Bongo nessa primeira conferência, no qual o ditador fala que os acadêmicos ali reunidos eram "'os representantes dos povos bantu' reunidos ali com seus 'pais e com os pais dos seus pais orgulhosos de tudo aquilo que nós herdamos deles." (tradução livre) ${ }^{28}$.

\footnotetext{
${ }^{27}$ This presumption was dear to Romantic nationalists and colonialists who viewed race, culture, and language as different facets of unitary national identities arrayed hierarchically. (SCHOENBRUN, 2001, p. 2)

${ }_{28}$ Assembled scholars learned from Bongo that they were "the representatives of the Bantu people," assembled together with their "fathers and the fathers of our fathers ...proud of ... all that we have inherited from them." (SCHOENBRUN, 2001, p.4)
} 
A criação do CICIBA foi ratificada durante a Segunda Conferência, ocorrida também em Libreville entre os dias 4 e 8 de janeiro de 1983. Os Estados signatários presentes nessa ratificação foram: Angola, Comores, Congo, Gabão, Guiné Equatorial, República Centro-Africana, São Tomé e Príncipe, Zaire e Zâmbia. Ali se encontrava delegações do Burundi e Ruanda e a presença de observadores da Bélgica, Camarões, Canadá, França e Nigéria. Por fim, estavam presentes as organizações internacionais Agência de Cooperação Cultural e Técnica (ACCT), Instituto Cultural Africano (ICA), Associação Internacional para as Pesquisas sobre Civilizações e Literaturas Africanas (AIRLA), Organização das Nações Unidas para a Educação, a Ciência e a Cultura (UNESCO) e o Programa das Nações Unidas para o Desenvolvimento (PNUD) (TOURNEUX, 1983, p.95).

A cidade de Libreville foi designada como sede. O CICIBA seria financiado, em grande parte, pelo Gabão, e receberia contribuições dos Estados-membros da organização e do PNUD. A quantidade de países e organizações envolvidas nos indica a capacidade de articulação política regional e internacional de Omar Bongo em torno da ideia de uma união da região de povos de línguas bantu. Destacamos, por exemplo, as interações internacionais do presidente nesse período de formação da instituição: em 1981, visita Ronald Reagan em Washington, nos Estados Unidos; em 1982, recebe o líder religioso católico Papa João Paulo II; e, em 1983, recebe a visita do presidente da França, François Mitterrand. Diante dessa contextualização apresentada, nos questionamos: qual a finalidade política da criação do CICIBA caracterizado pela presença de programas de pesquisas interdisciplinares? Tourneux (1983) nos apresenta uma resposta:

\begin{abstract}
Seu objetivo político é reduzir as barreiras linguísticas herdadas da divisão colonial (fala-se francês, inglês, português e espanhol na região) e superar os obstáculos decorrentes da diversidade de regimes políticos. [...] Os governos, por sua vez, esperam que o CICIBA ajude os povos desta vasta região a conscientizar-se dos lacos que os unem através das etnias e dos Estados. (TOURNEUX, 1983, p.95-6 - grifos nossos, tradução livre ${ }^{29}$
\end{abstract}

\footnotetext{
${ }^{29}$ Son but politique est de diminuer les barrières linguistiques héritées du découpage colonial (on parle français, anglais, portuguais et espagnol dans la zone concernée) et de surmonter les obstacles surgissant de la diversité des régimes politiques. [...] Les politiques, de leur côté, espèrent que le CICIBA aidera les peuples de cette immense región à prendre conscience des tiens que les unissent, par-delà les ethnies et les États. (Tourneux, 1983, p.95-6)
} 
O CICIBA, nessa perspectiva, traz do "berço" a ideia da união regional dos Estados circunscritos aos povos de língua bantu, sendo que grande parte deles pertencem à região da África Central. Todavia, buscamos outras interpretações quanto à criação e manutenção de uma instituição que publica o boletim arqueológico Nsi. Afinal, os seus editoriais apresentam-se na língua francesa e inglesa: apenas em francês - dois, e em francês e inglês - cinco, de um total de sete editoriais. Entre os anos de 1987 e 1992 não foi publicado nenhum artigo em outros idiomas, como o português ou o espanhol. Aliás, notamos que a francofonia e a anglofonia foram assuntos recorrentes, como destacamos:

Semestral, o boletim publica os seus textos em francês e em inglês. (Nsi, 1987, n.1, p.1 - tradução livre)

Deve-se admitir que os nossos colegas anglófonos ainda não estão convencidos do valor do Nsi. (Nsi, 1989, n.5, p.3 - tradução livre)

Segundo [ponto] - uma pequena abertura do Nsi para o mundo africano anglófono (África Oriental e Austral). (Nsi, 1991, n.8-9, p.3 tradução livre)

[O] segundo [ponto indicado no trecho do editorial acima datado de 1991] depende do Departamento de Arqueologia e do Museu do CICIBA: essa falta de abertura está sendo resolvida [...] (Nsi, 1992, n.10-11, p.3 - tradução livre) ${ }^{30}$

De um lado, nessas citações percebemos a dificuldade, anunciada pelos editores, de adotar uma ou duas línguas para o boletim em meio à diversidade linguística dos Estados oriundos das colonizações de diferentes países, como a França, a Inglaterra, Portugal e a Espanha, os quais continuavam a manter influência sobre as antigas colônias. Por outro, o problema linguístico aponta para a aparente ruptura da arqueologia da África Central em relação à da África Oriental e Austral, em especial, os Estados de Botsuana, Namíbia, Zâmbia e

\footnotetext{
${ }^{30}$ Semestriel, le bulletin publie en français et en anglais ses textes. (Nsi, 1987, n.1, p.1)

[I]l faut bien avouer que nos collègues anglophones ne sont pas encore convaincus de l'intérêt de Nsi. (Nsi, 1989, n.5, p.3)

$2^{\circ}$ - une faible ouverture de Nsi sur le monde africain anglophone (Afrique Orientale et Australe). (Nsi, 1991, n.8-9, p.3)

[L]e seconde dépend du Départment d'Archéologie et du Musée du CICIBA: ce manque d'ouverture est en voie de résolution $[. .$.$] (Nsi, 1992, n.10-11, p.3)$
} 
Zimbábue, citados no editorial de 1987, número dois, cujas regiões habitam povos falantes de línguas bantu. Diante dessas circunstancias, a afirmação de Tourneux (1983) é contradita nos editoriais, quanto ao objetivo do CICIBA de reduzir as barreiras linguísticas e promover a união da "zone bantuphone".

Retomemos a nossa análise sobre a finalidade política, social e ideológica da criação do CICIBA, no ano de 1983, uma iniciativa de Omar Bongo, presidente-ditador do Gabão, com um departamento de Arqueologia responsável pela publicação do boletim Nsi.

Ngolet (2000), em nota do seu texto, afirma que:

A criação do Centro International das Civilizações Bantu (CICIBA) foi motivada pelo desejo de Bongo de estabelecer um vínculo histórico entre o rei Makoko [herói mítico dos pigmeus] e ele próprio, de modo a legitimar a sua ambição. (NGOLET, 2000, p.71 - tradução livre) ${ }^{31}$

Uma afirmação como essa merece ser apreciada no âmbito da arqueologia pós-colonial da África Central no período.

Como já dito até o momento, construir uma arqueologia autóctone e que se sustentasse com as verbas dos governos independentes era uma demanda entre os arqueólogos e alguns políticos africanos e organismos internacionais como a UNESCO e o PNUD. A pesquisa arqueológica na Árica Central necessitava de recursos, os quais vieram dos governos signatários do CICIBA e mais, especificamente, do Gabão. Paul-Marc Henry, da UNESCO, em relatório da sua missão de observação das atividades do CICIBA, datado de 08 de outubro de 1984, quase um ano depois da sua fundação, informa:

Relativo aos outros projetos mencionados no relatório de M. Barnabé
Karorero a começar com os projetos arqueológicos, eles serão objeto
de um programa de trabalho anual com os recursos orçamentais, de
pessoal e de serviços que estarão sujeitos à aprovação da Mesa
Redonda* e servirá de base às eventuais contribuiç̃̃es dos governos
e das instituicões que podem participar dos trabalhos do Centro
[CICIBA]. (Os recursos orçamentários deste relatório serão
apresentados apenas como ilustração). (HENRY, 1984, p.3 - grifos
nossos, tradução livre)

${ }^{31}$ The creation of the CICIBA (Centre International des Civilizations Bantu) was motivated by Bongo's wish to establish a historical link between King Makoko and himself so as legitimize his ambition. (NGOLET, 2000, p.71)

${ }^{32}$ Concernant les autres projets mentionnés par le rapport de M. Barnabé Karorero à commencer par des projets archéologiques, ils feront l'objet d'un programme de travail annuel comportant les prévisions 
A existência de projetos arqueológicos financiados pelos governos locais, como verificado nesta citação, era o cenário idealizado pelos intelectuais-arqueólogos africanos para trazer à tona versões multivocais ou marginalizadas do passado que, antes dos anos 1980, tinham pouco incentivo para a análise e publicação.

Na perspectiva crítica dos estudos pós-coloniais, era essencial enfocar os períodos anteriores ao processo colonial na tentativa de destacar a agência dos povos africanos. Entretanto, a criação de versões locais dessa agência de grandes líderes do passado da África Central, como o destaque dado por Omar Bongo ao rei Makoko, conforme Ngolet (2000), poderia não implicar na criação de uma versão multivocal da antiguidade da civilização africana. Como um exemplo tradicional disso, é sabido o papel dos griots, contadores dos grandes feitos dos antigos líderes e das genealogias dos clãs considerados importantes, na perpetuação das versões locais do passado através da tradição oral.

Nesse caso, de um lado, poderíamos interpretar que o incentivo político aos estudos que se debruçassem sobre o período pré-colonial, especificamente, sobre a agência dos líderes políticos do passado Bantu assunto "pertinente" aos contextos de formação dos Estados nacionais africanos - estaria associado a certa ambição do presidente do Gabão, Omar Bongo. Por outro, os arqueólogos africanos, que tinham dificuldades de inserção nas instituições e publicações do "Ocidente", tinham o CICIBA como uma instituição que incentivava o trabalho de campo, a musealização das coleções regionais e a publicação dos resultados através do boletim Nsi.

Logo, essa seria uma possível explicação para a formação do Departamento de Arqueologia do CICIBA, juntamente com o Museu e o Banco de Dados (CICIDATE) sobre as pesquisas relativas aos povos de língua bantu.

\footnotetext{
budgétaires et les moyens en personnel et en services qui sera soumis à la approbation de la Table Ronde et servira de base aux contributions éventuelles des Gouvernements et des Institutions susceptibles de participer aux travaux du Centre. (Les prévisions budgétaires dudit rapport seront soumises seulement à titre indicatif). (HENRY, 1984, p.3)

* A Mesa Redonda - la Table Ronde - proposta para o dia 11 de dezembro de 1984, seria composta pelos Estados-membros do CICIBA, pelos Estados interessados mas fora da região, pelas organizações científicas e universitárias. (HENRY, 1984, p.1)
} 
Para os arqueólogos africanos da corrente pós-colonial, como, por exemplo o intelectual Théophile Obenga, diretor do CICIBA, a criação e manutenção de um centro de estudos seria a materialização de uma perspectiva científica endógena sobre a agência dos povos da África Central. Poderíamos considerar essa criação institucional como uma forma de descolonizar as relações de poder entre africanos e africanistas na Arqueologia, já que os primeiros teriam espaço para publicação dos trabalhos no boletim Nsi.

Diante disso tudo, a trajetória da Arqueologia da África Central nas décadas de 1980 e 1990 é caracterizada pela difícil tentativa de definir uma região marcada pela hegemonia histórica dos povos bantu. Hegemonia esta aparentemente manipulada pelo líder político Omar Bongo em meio aos embates das heranças intelectuais do colonialismo e dos estudos póscoloniais.

\section{ÁFRICA AUSTRAL}

A África Austral, também nomeada de Meridional ou de Sul da África, é composta por África do Sul, Zimbábue, Namíbia, Zâmbia, Botsuana, Lesoto, Suazilândia e Moçambique, como podemos apontar no mapa sete.

\section{Mapa 7 - África Austral - fronteiras políticas internacionais e províncias da África do Sul}

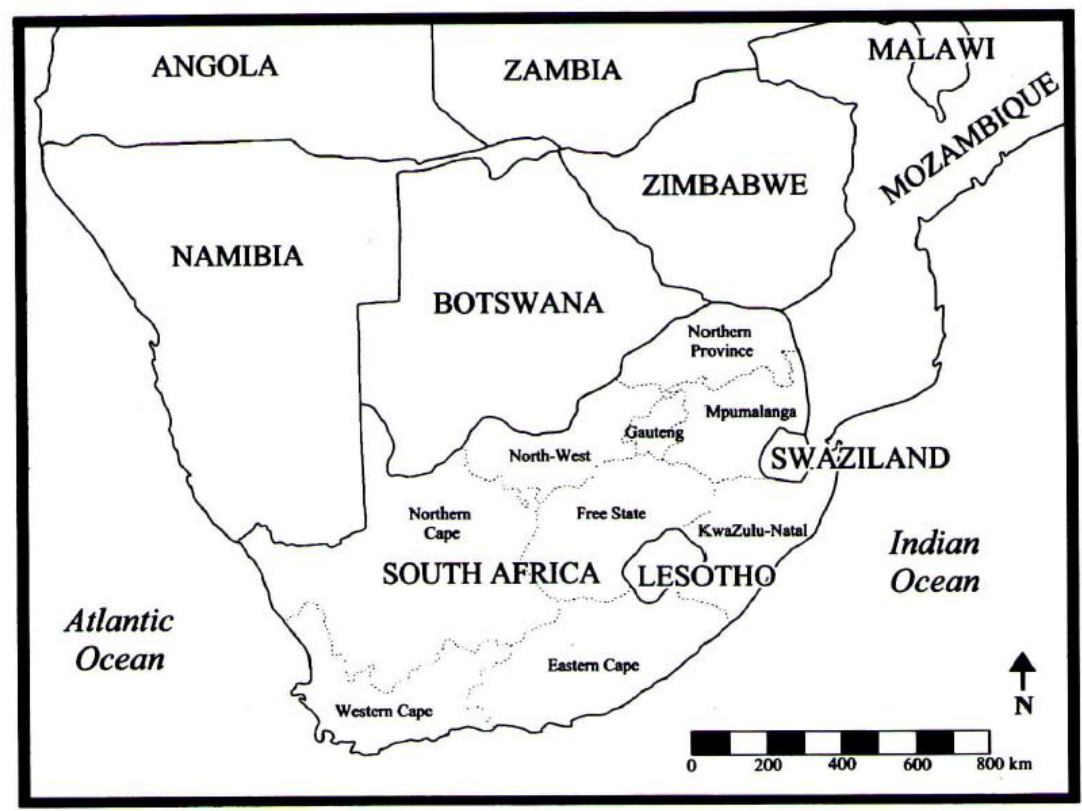

Fonte: MITCHELL, 2002, p.11. 
Essa delimitação da parte sul do continente também pode incluir partes de Angola, Zâmbia e o Malawi. Mitchell (2002), especialista em arqueologia da região, apresenta a seguinte definição da região:

Ao escrever sobre o passado da África a maioria dos arqueólogos empregam 'Sul da África' para se referir a essa parte do continente situada ao sul dos rios Zambezi e Kunene. [...] [B]iogeograficamente, arqueologicamente e etnograficamente as terras situadas ao sul do Zambezi e do Kunene são distinguíveis das terras do Centro-Sul da África, não menos, por ser um lar para diversas populações Khoisan da África. (MITCHELL, 2002, p.10 - grifo nosso, tradução livre) ${ }^{33}$

Por sua vez AJH Goodwin, primeiro editor do boletim TSAAB, no editorial número um, página dois, de dezembro de 1945, define a cobertura geográfica da publicação: África do Sul e os Estados vizinhos, a saber, Rodésia do Sul, Suazilândia e sudoeste da África. O subtítulo desse boletim - Da África Central ao Cabo - apoia a delimitação geográfica que consideramos para 0 nosso estudo nesse item da História da Arqueologia da África Austral.

Nessa dissertação, para fins de padronização da terminologia, recorreremos ao termo África Austral. Tomamos essa precaução para evitarmos equívocos entre as expressões Sul da África (Southern Africa região), como adotou Mitchel (2002) no trecho acima sublinhado, e África do Sul (South Africa - Estado) ao utilizarmos em português. Por outro lado, a coleção História Geral da África, republicada recentemente no ano de 2010, também a nomeia como África Austral.

A região é caracterizada por um grande planalto no interior com áreas marginais a ele compostas de montanhas e de planícies costeiras com lagos, além de uma depressão. Esse planalto, central, separa a região leste dos desertos do Kalahari e da Namíbia. O sul do Zimbábue e parte da África do Sul apresentam uma vegetação de estepe. O clima é tipo mediterrânico no extremo sul do continente, com uma vegetação característica. Os principais rios da região são o Zambezi, o maior, e o Limpopo. Ambos deságuam no Oceano

\footnotetext{
${ }^{33}$ [W]hen writing about Africa's past most archaeologists employ 'southern Africa' to refer to that part of the continent lying south of the Zambezi and Kunene rivers. [...] And yet biogeographically, archaeologically and ethnographically the lands lying south of the Zambezi, and Kunene are distinguishable from south-central Africa, not least in being home to Africa's diverse Khoisan populations. (MITCHELL, 2002, p.10)
} 
Índico. O rio Gariep, também chamado Orange, e o rio Vaal deságuam no Oceano Atlântico. O rio Kunene, citado no trecho acima para fins de delimitação arqueológica da região, drena o Sudoeste de Angola, como podemos verificar no mapa oito.

\section{Mapa 8 - Hidrografia, relevo e desertos}

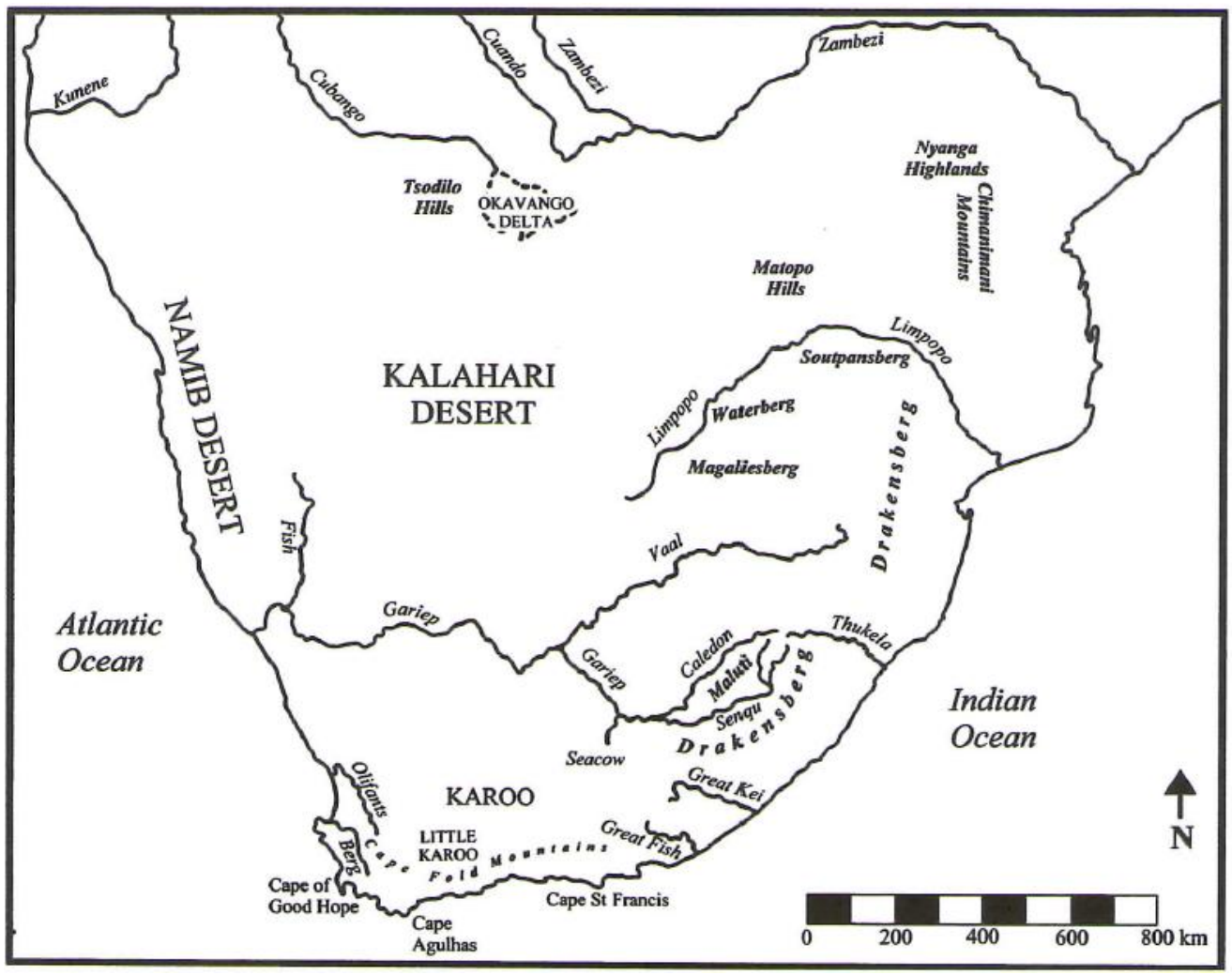

Fonte: MITCHELL, 2002, p.12.

$\mathrm{Na}$ perspectiva dos adeptos da corrente da Nova Arqueologia, alguns dos quais foram editores do TSAAB, como o arqueólogo sul-africano Hillary John Deacon, esses fatores climáticos e topográficos são fundamentais nas discussões sobre as adaptações humanas aos recursos ecológicos distribuídos na região ao longo de milhões de anos (MITCHELL, 2002, p.18).

Mitchell (2002) divide a História da Arqueologia da África Austral em cinco fases, considerando que as características dessas são cumulativas e não substitutivas.

A primeira fase refere-se ao final do século $X V$ até o século $X V I I I$, período no qual os viajantes europeus registraram textualmente suas "explorações arqueológicas" sobre artefatos líticos e arte rupestre. Segundo 
Robertshaw (1979), a primeira escavação arqueológica realizada na África Austral foi feita pelo naturalista sueco Anders Erikson Sparrman em 22 de janeiro de 1776. Seu "relatório" estaria situado em um livro de memórias de viagens de Sparrman publicado somente no ano de 1977, duzentos e um anos depois, pela Van Riebeeck Society. Conforme o autor, o naturalista escavou uma estrutura composta por pedras nas proximidades do Great Fish River, atual província de Eastern Cape, África do Sul. Gabel (1985, p.242) acrescenta que, em 1721, o Bispo de Moçambique apresentou um relatório a Real Academia de História de Lisboa sobre algumas pinturas rupestres de animais que foram localizadas na sua diocese. Assim, a primeira cópia das pinturas da África Austral foi aparentemente realizada por Johannes Schumacher nos anos de 1776 e 1777 (GABEL, 1985).

A segunda fase, ao longo do século XIX, foi marcada pelas iniciativas de indivíduos, como: Robert Moffat que, em 1829, descreveu ruínas de assentamentos abandonados na província Transvaal; Cornallis Harris que, em 1835, copiou pinturas rupestres de rinocerontes no Magliesberg Valley, Transvaal; em 1850, Richard Thornton geólogo da Livingstone's Zambezi Expedition descobriu ferramentas líticas em Natal e na embocadura do Rio Zambezi; T.H. Bowker que coletou na embocadura do Rio Great Fish; Langham Dale, em 1870, com sua coleta em Cape Town; e, Andrew Anderson, em 1887, em coleta no interior da região. Esses arqueólogos, alguns amadores, recolhiam ferramentas líticas antigas as quais eram enviadas para a GrãBretanha para alimentar as coleções dos antiquários. Além desses, o linguista Wilhelm Bleek, em 1870, recolheu os testemunhos de informantes Bushman (GABEL, 1985; SHEPHERD, 2003).

Segundo Shepherd (2003, p.828-9), entre os anos de 1870 e 1923, duas ideias eram subjacentes aos estudos de pré-história na África Austral. A primeira era a referência à terminologia do "Paleolítico" francês para o estabelecimento das sequências cronológicas da antiguidade da região, como o uso corrente dos termos Paleolítico, Neolítico, Aurignacian types, Mousterian e Solutro-Magdalenian types. A essa nomenclatura temporal, se deve acrescentar a teoria difusionista a qual começou a vicejar na Europa no período. A segunda ideia seria a identificação da antiguidade sul-africana com 
a presença do grupo étnico atual Bushman ou San. Para comprovar a aplicação das terminologias europeias e da explicação difusionista no período, Mitchell (2002, p.33) e Gabel (1985, p.243) assinalam que os artefatos da África Austral foram considerados pela comunidade acadêmica europeia naquele momento para corroborar a natureza mundial da ldade da Pedra, expressão criada por C.J.Thomsen, em 1836, e das terminologias Paleolítico e Neolítico.

Segundo Shepherd (2003, p.828), nesse período entre 1870 e 1923, foram publicados cerca de cento e trinta textos científicos sobre a arqueologia da África do Sul, Zimbábue, Botsuana, Suazilândia e Moçambique em revistas locais, entre elas, Cape Monthly Magazine, Transactions of the South African Philosophical Society, cujo nome foi alterado para Royal Society of South Africa. Além desses, foram divulgados muitos artigos em revistas metropolitanas, como: Proceedings of the Society of Antiquaries, Proceedings of the Ethnological Society of London e Journal of the Anthropological Institute. Até 1945, data do lançamento do boletim TSAAB, essas revistas científicas especializadas deram publicidade aos estudos arqueológicos da África Austral realizados em grande medida por colonos, exploradores, militares, administradores da colônia, médicos, geólogos, antiquários, enfim, uma diversidade de autores que podemos definir como arqueólogos amadores.

No início do século $X X$, os achados de machados-de-mão do tipo Acheulean - Acheulean handaxes - atualmente datados em um milhão e meio de anos, em sítios sul-africanos com boa estratigrafia, muito semelhantes àqueles achados europeus, foram problematizados pelos especialistas preocupados em estabelecer uma terminologia local. Segundo Mitchell (2002, p.34), os primeiros arqueólogos a suscitar essa discussão foram Haddon (1905), Pèringuey (1911) e Neville Jones (1920). Esse último elaborou sequências regionais para o Zimbábue e o Norte do Cabo.

A década de 1920 foi marcada pela descrição do fóssil de Australopithecus africanos pelo anatomista Raymond Dart, em 1925, cujo trabalho foi publicado na revista Nature e pela atuação do primeiro arqueólogo profissional sul-africano Astely John Hilary Goodwin. Este nasceu em 
Pietermaritzburg em 1900. Graduou-se em arqueologia na University of Cambridge e com 23 anos de idade já trabalhava na University of Cape Town, onde foi atuante até o seu falecimento, em 1959 (cf. figura dois).

Goodwin juntamente com Clarence Van Riet Lowe e Neville Jones estabeleceram as fundações da terminologia da antiguidade da África do Sul. Lowe, inicialmente, defendia a divisão da antiguidade da África Austral em Earlier Stone Age (ESA), a qual pertencia os machados acheulenses, e Later Stone Age (LSA), que foi subdividida por ele.

Considerava que era preciso uma "abordagem estritamente científica para a exploração de campo e para a elaboração de conclusões." ${ }^{\text {"34 }}$ (HAUGHTON, 1960, p.761). Essa fora uma proposta de profissionalização da disciplina em uma época de forte atuação dos "amadores". Seu trabalho metódico resultou na obra intitulada Method in Prehistory (1945). Colaborou na fundação da South African Archaeological Society (SAAS), trabalhando como secretário, editor do TSAAB e, foi o presidente da sociedade até seu falecimento. Fundou o Athenaeum Trust que fora uma espécie de centro das sociedades científicas e culturais da África do Sul. Também foi secretário-geral da Royal Society of South Africa e, no ano da sua morte, também havia sido nomeado seu presidente (HAUGHTON, 1960).

Figura 2 - Astely John Hilary Goodwin

Fonte: INDIANA UNIVERSITY, acesso em 25/10/2012.
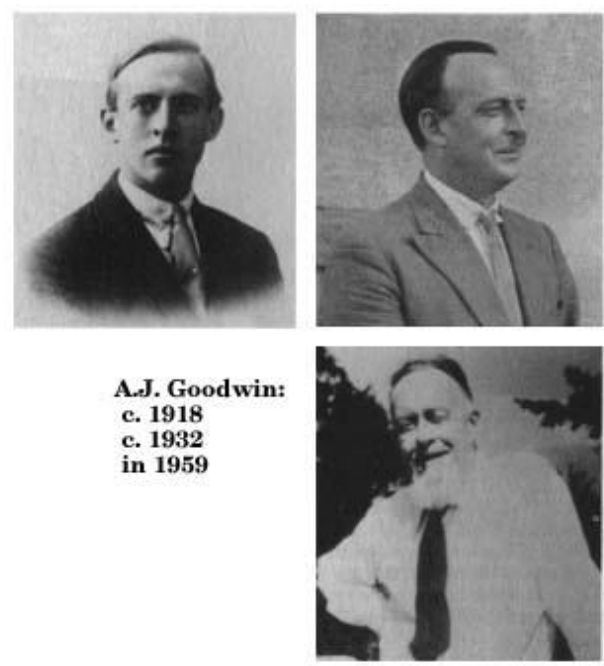

\footnotetext{
${ }^{34}$ Goodwin stressed the need for the strictly scientific approach to the field exploration and to the drawing of conclusions. (HAUGHTON, 1960, p.761)
} 
O estudioso preocupou-se em demasia em estabelecer uma nomenclatura cronológica própria baseada nas observações das coleções de artefatos líticos da África Austral. Em 1926, na Conferência de Pretoria, organizada pela South African Association for the Advancement of Science, ocorreram vários debates sobre cronologia e terminologia da região (GABEL, 1985, p.251). No ano de 1928, Miles Burkitt, arqueólogo de Cambridge, instrutor de Goodwin, Louis Leakey e Desmond Clark, lançaram o livro South Africa's Past in Stone and Paint.

No ano seguinte, em 1929, Goodwin juntamente com Clarence "Peter" Van Riet Lowe, lançaram o livro The Stone Age Cultures of South Africa onde propuseram a subdivisão da antiguidade desta região em três Eras: Earlier Stone Age (E.S.A), Middle Stone Age (M.S.A) e Later Stone Age (L.S.A) (MITCHELL, 2002, p.34; GABEL, 1985, p.251). Esse trabalho, posteriormente, embasou os estudos da antiguidade do sul e do leste da África. Goodwin (1946a, p.75) apresentou em artigo publicado no TSAAB os seguintes desenhos para auxiliar na caracterização dos artefatos líticos - identificados com as letras $a-g$ - desses três grandes períodos. Veja figura três:

Figura 3 - Representação dos artefatos líticos dos períodos E.S.A., M.S.A. e L.S.A.

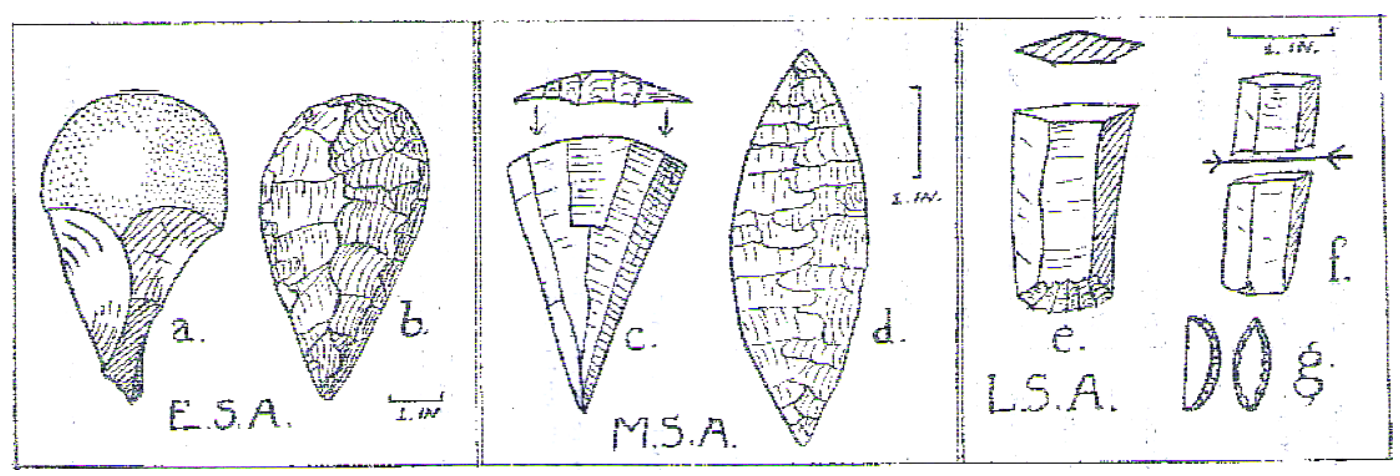

Fonte: GOODWIN, 1946a, p.75

A terminologia criada visava posicionar a antiguidade da África Austral com características próprias perante a antiguidade ("pré-história") europeia, especificamente, a francesa, que era tida como referência terminológica entre alguns arqueólogos africanos e africanistas naquele momento. 
A subdivisão em três idades elaborada por Goodwin e Van Riet Lowe, e aperfeiçoada através do trabalho com outros pesquisadores, como Neville Jones - escavador dos sítios rodesianos (Zimbábue), Sawmills, Hope Foutain, Nawatugi e Bambata Cave - ainda é empregada, com modificações, na literatura arqueológica da África Austral e, também, de modo geral, na África subsaariana (GABEL, 1985, p.252). Em 1929, o arqueólogo francês Abbé Henri Breuil interessou-se pelas coletas de Jones na África Austral. Esse interesse originou uma relação entre ele e Smuts, que the ofereceu exílio na África do Sul durante a Segunda Guerra Mundial. Durante o exílio, Breuil debruçou-se sobre a arte rupestre e os vestígios do Paleolítico na África Austral (GABEL, 1985, p.253).

O período Iron Age foi acrescentado na divisão temporal posteriormente, devido ao aprofundamento dos estudos, na década de 1950, sobre a migração dos povos de língua bantu e as suas práticas de metalurgia. Após a Segunda Guerra Mundial, com o desenvolvimento dos processos de datação absoluta, foi possível qualificar as datas antes conseguidas pela datação relativa baseadas nas evidências faunísticas, geológicas e de artefatos arqueológicos comparados.

A constituição de uma arqueologia local foi acompanhada entusiasticamente pelo General Jan Christiaan Smuts, primeiro-ministro da África do Sul, entre os anos 1939 e 1948, e presidente da South African Association for the Advancement of Science. Ele tornou-se "padrinho político" da pesquisa arqueológica sul-africana e, ainda, em 1935, fundou o Bureau of Archaeology posteriormente denominado de Archaeological Survey. De acordo com Shepherd (2003, p.831), essa instituição foi assentada no fervilhamento das novas descobertas e na divulgação de interpretações que colocavam esse país no panorama mundial dos estudos da antiguidade. Anos depois, em junho de 1945, a South African Archaeological Society foi fundada e, em dezembro do mesmo ano, o boletim TSAAB foi lançado.

Em 1939, com a demissão do primeiro-ministro J.B.M.Hertzog, o General Jan Christiaan Smuts retorna ao cargo e apoia o primeiro-ministro britânico Winston Churchill. Nesse retorno, declarou guerra à Alemanha e 
investiu no discurso da União entre as elites e classes médias adeptas dos discursos dos britânicos e dos africâners ou bôers. Ainda, segundo Shepherd (2003), entre 1923 e 1948, havia uma ideia de União defendida por Smuts que demonstrava indiferença às lutas anticoloniais e nacionalistas dos colonos africâners. Porém, isto não indicava uma abertura para a participação política dos mestiços e negros sul-africanos.

Essa ideia de União, em nossa interpretação, parece estar associada ao estímulo do líder político Smuts à criação de uma terminologia local para a "pré-história nacional" da África do Sul (cf. figura quatro). Simultaneamente, nessa terceira fase da História da Arqueologia da África Austral, aparece nas pesquisas da região a preocupação da corrente arqueológica históricoculturalista a fim de sistematizar os estudos realizados desde 1860. Buscavase nomear as culturas, as indústrias e os diferentes modos de exploração dos recursos ecológicos que poderiam estar associados à difusão ou migração (SHEPHERD, 2003, p,830).

Em meados do século XX ocorreu, na África do Sul, a institucionalização da ciência arqueológica focada nas peculiaridades do passado local. $O$ incremento dos métodos de datação facilitou e revolucionou a pesquisa no Great Zimbabwe e nos sítios dos antigos hominídios. O patrocínio de Smuts e o trabalho de Goodwin na constituição de um público-leitor entusiasta da arqueologia, por meio do lançamento da TSAAB, colocaram o país na candidatura de sede do The Second Pan-African Congress, em 1951, e em parcerias científicas com outros países africanos, como o Quênia (SHEPHERD, 2003, p,832). 
Figura 4 - 0 arqueólogo Van Riet Lowe, sentado à esquerda, o general Jan Smuts, sentado ao lado de Lowe, e a equipe de escavação no sítio em Mapungubwe, 1930.

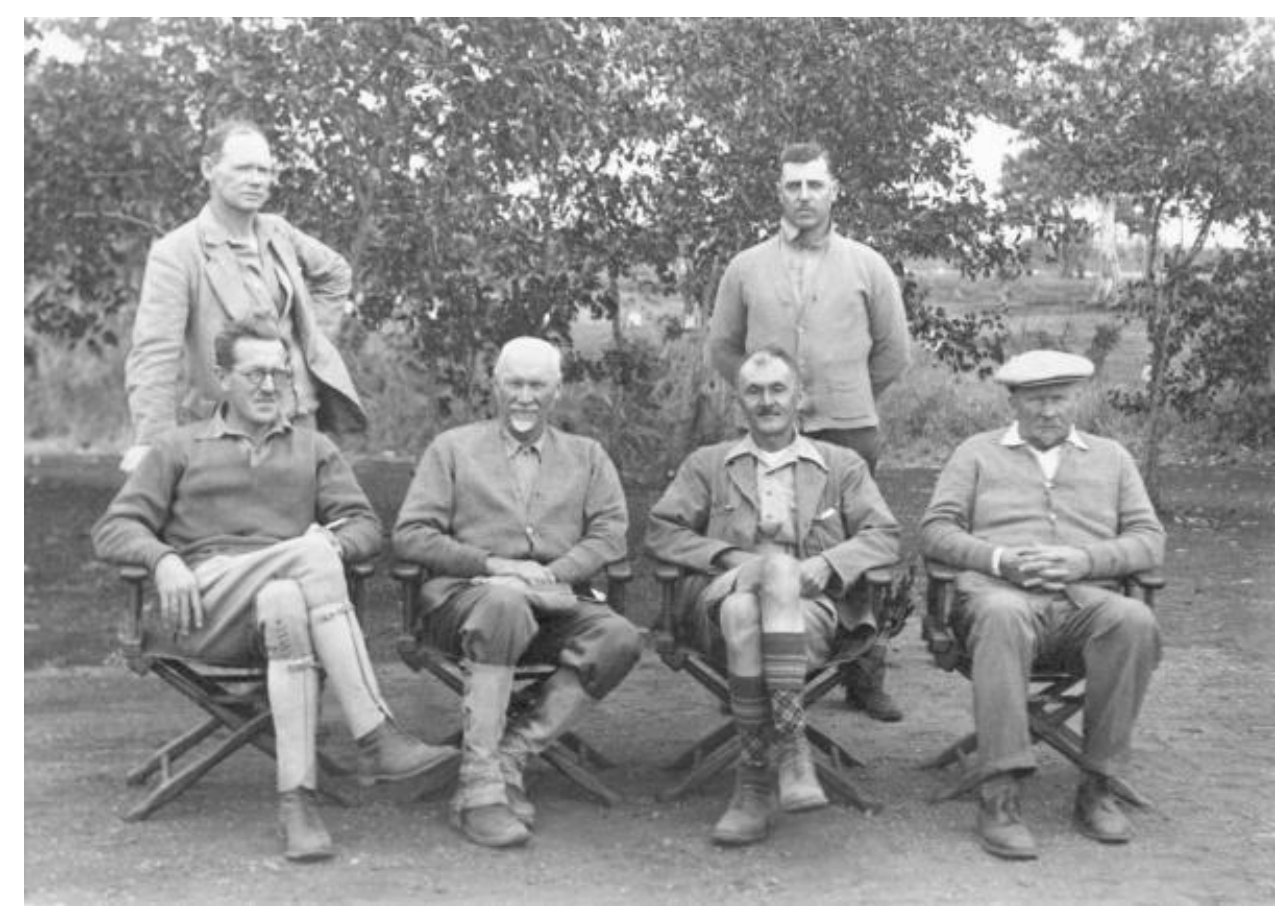

Fonte: THE SOUTH AFRICAN ARCHAEOLOGICAL SOCIETY a, acesso em 25/10/2012.

Conforme Gabel (1985, p.253), "Peter" Van Riet Lowe, nos anos de 1923 e 1928, enquanto era engenheiro encarregado da construção de uma ponte em Orange Free State, identificou aproximadamente 300 sítios arqueológicos. Em 1935, sob a designação de Smuts, tornou-se o diretor do Bureau of Archaeology - depois nomeado Archaeological Survey - e recebeu o título de professor de arqueologia da University of Witwatersrand. Lowe ainda desenvolveu pesquisas na Uganda, Bechuanaland (Botsuana) e Moçambique.

Para Shepherd (2003) houve uma ruptura nesta trajetória de associação pan-africana e de financiamento da pesquisa arqueológica devido a dois fatos da história da África do Sul. O primeiro é a eleição de Daniel François Malan, em 1948, apoiado pela plataforma política do apartheid. Antes da implosão da Segunda Guerra Mundial e depois dela, algumas organizações de cunho fascista haviam surgido no país e cresceram muito politicamente. O segundo fato foi à morte do general Jan Smuts, em 1950, patrocinador político da arqueologia sul-africana, acontecimento este lamentado no TSAAB. Como podemos verificar no trecho do obituário de Smuts: 
Nós lamentamos profundamente o falecimento de um grande homem, um grande cientista e estadista, e, em todas as coisas, um grande do sul-africano.Marechal de Campo Ilustre Deputado J.C. Smuts foi valoroso em numerosos campos, mas para nós ele permanecerá como um membro fundador vitalício, cuja resposta à formação desta sociedade foi rápida e generosa, um membro companheiro que participou das reuniões conosco e teve um interesse entusiasta no que estava acontecendo em nossa jovem, imatura Sociedade. (TSAAB, dezembro 1950, v.5, n.20, p. 125 - grifos nosso, tradução livre $)^{35}$

Ainda segundo Shepherd (2003), com a eleição de Daniel François Malan, ocorreu uma mudança na trajetória da arqueologia sul-africana: a substituição da consciência histórica de caráter nacional - ideia de União - para um "paroquialismo de africâners". O novo governo declinou a possibilidade de realizar o The Second Pan-African Congress, em 1951, na África do Sul. Nesse período de transição algumas sínteses da antiguidade da África Austral foram publicadas: em 1949, Neville Jones lança Prehistory of Southern Rhodesia; em 1950, J.D. Clark lança The Stone Age Cultures of Northern Rhodesia e, em 1959, lança The Prehistory of Southern Africa (GABEL, 1985, p.262). Ainda em 1959, Goodwin faleceu, deixando como legado a formação acadêmica de vários arqueólogos. Em 1962, a instituição Archaeological Survey foi fechada e os funcionários transferidos para a University of the Witwatersrand.

A quarta fase da História da arqueologia da África Austral compreende as décadas de 1960 e 1970, que teve a influência do modelo anglo-americano sobre o modelo local (SHEPHERD, 2003, p.835; MITCHELL, 2002, p.35). A passagem da corrente do Culturalismo-Histórico para a Nova Arqueologia foi embasada no rigor teórico próprio desta abordagem, nos estudos das adaptações do homem aos recursos ecológicos, das estratégias de sobrevivência e da reconstituição do paleoambiente. Os estudos sobre arte rupestre também passaram por essa transição. Além de John Parkington, podemos citar o sul-africano Hilary John Deacon, que assinou editoriais na TSAAB e foi casado com Janette Deacon, editora principal da TSAAB no

\footnotetext{
${ }^{35}$ We deeply mourn the passing of a great man, a great scientist and statesman, and, in all things, a great South African. Field-Marshal the Right Honourable J. C. Smuts held many honours in numerous fields, but to us he will remain a Foundation Life Member, whose response to the formation of this Society was quick and generous, a fellow member who attended meetings with us and took a keen interest in what was happening in our young, unfledged Society. (TSAAB, dezembro 1950, v.5, n.20, p.125)
} 
período de 1987 e 1993, os quais fizeram estudos de modelos de subsistência apoiado em observações etnográficas dos San no deserto do Kalahari.

A corrente da Nova Arqueologia na África do Sul marcava a passagem de uma arqueologia realizada também por amadores para uma estritamente "científica". Como consequência, houve uma limitação na sua participação na pesquisa arqueológica que é refletida pela queda de artigos publicados por amadores na TSAAB nos anos 1970, segundo Shepherd (2003, p.836).

Nessas décadas, a África do Sul ficava mais isolada conforme a sua atuação e influência sobre a Rodésia do Sul. Em 1960, as elites brancas rodesianas haviam adotado o modelo racial discriminatório inspirado nos dirigentes sul-africanos. A pressão de alguns Estados sobre a situação política da África Austral foi contínua e culminou com a solicitação, desde 1964, de boicote àquele país pelos membros da Organização da Unidade Africana (OUA), criada em 1963. No entanto, a dependência econômica e estrutural dos países da região em relação à potência sul-africana impedia o bloqueio das relações. A África Austral era composta por Estados que dependiam economicamente da África do Sul para a contratação de mão-de-obra na indústria mineradora, nas plantações, nos estaleiros, além de utilizar a estrutura dos meios de transportes sul-africanos (M'BOKOLO, 2011, p.638).

Nessa situação política, Shepherd (2002) propõe duas formas de ver a relação entre a Arqueologia e o regime segregacionista na África do Sul:

i) A Arqueologia como apolítica e, assim, não sofrer restrições governamentais na pesquisa;

ii) A Arqueologia como parceira da resistência contra o racismo institucional.

A relação da Arqueologia como parceira da resistência, segundo o autor, deve-se ao autoritarismo dos governos segregacionistas que divulgavam que negros e brancos "chegaram" à África Austral simultaneamente e às potencialidades dos vestígios exploradas por arqueólogos ativistas antiapartheid. Em contraposição, havia aqueles especialistas que queriam as 
pazes com o governo e os leitores da classe média. Mitchell (2002), por sua vez, adiciona outro elemento nessa "equação" - a hesitação:

[A] relutância da maioria dos arqueólogos em engajar-se mais ativamente na política e a eficácia absoluta da segregação racial confinou esses resultados [sobre a antiguidade da prática da agricultura na região] na academia. No Zimbábue, a arqueologia da Idade do Ferro foi efetivamente popularizada por Summers e Garlake, mas, pressões políticas do regime Rhodesia Front os levou à renúncia e / ou ao exílio. (MITCHELL, 2002, p.36 - tradução livre, grifos nossos) ${ }^{36}$

Paradoxalmente à crise resultante da censura na Arqueologia da África Austral e a hesitação política de um grande número de arqueólogos, entre as décadas de 1970 e 1990, houve um grande investimento público nos museus e universidades, possibilitando a formação de novos centros de pesquisas com profissionais formados local e externamente. Segundo Shepherd (2003, p.835) esse financiamento do governo à pesquisa arqueológica foi devido ao aumento do investimento estrangeiro na economia capitalista racializada da África do Sul. O autor ainda destaca que:

O ressurgimento da arqueologia coincidiu com um período de rápido crescimento na economia sul-africana, quando o serviço arqueológico foi visto como parte do aparato cultural essencial de um Estado modernizador. A partir de agora, o governo do apartheid estaria na posição incomum de apoiar generosamente uma disciplina cujo principal trabalho estava em desmascarar a extensão da realização cultural negra. (SHEPHERD, 2002, p.198 - tradução livre) ${ }^{37}$

Esses investimentos governamentais em pesquisa arqueológica são explicados pela pressão das instituições econômicas mundiais para ceder empréstimos e financiamentos para os países africanos do bloco capitalista. Aqui cabe questionar quais as temáticas arqueológicas que foram contempladas. Nessa direção, para Martin Hall apud Shepherd (2002, p.198) essa situação bizarra foi "resolvida" pelos arqueólogos sul-africanos de duas

\footnotetext{
${ }^{36}$ Yet the disinclination of the most archaeologists actively to engage in politics and the sheer effectiveness of racial segregation confined these results to the academy. In Zimbabwe Iron Age archaeology was more effectively popularized by Summers and Garlake, but political pressures from the Rhodesia Front régime led to their resignations and / or exile. (MITCHELL, 2002, p.36)
}

37 The re-emergence of archaeology coincided with a period of rapid growth in the South African economy, when an archaeological service was seen as part of the essential cultural apparatus of a modernizing state. Henceforth, the apartheid government would be in the unusual position of generously supporting a discipline whose major work lay in unmasking the extent of black cultural achievement. (SHEPHERD, 2002, p.198) 
formas, através da escolha temática, para continuar a receber os financiamentos em pesquisa:

i) Evitaram os períodos mais controversos da antiguidade sul-africana, ou seja, o passado "recente". Veja o mapa nove abaixo que indica a concentração de sítio arqueológicos do período Stone Age identificados por círculos e triângulos;

ii) Utilizaram categorias tipológicas e linguagem técnica ininteligível para o público.

Essa escolha temática, ainda segundo Martin Hall apud Shepherd (2002), esvaziaria a possibilidade de discussão política fomentada pela análise dos vestígios arqueológicos na perspectiva cientificista da Nova Arqueologia.

\section{Mapa 9 - Alguns sítios arqueológicos da África Austral}

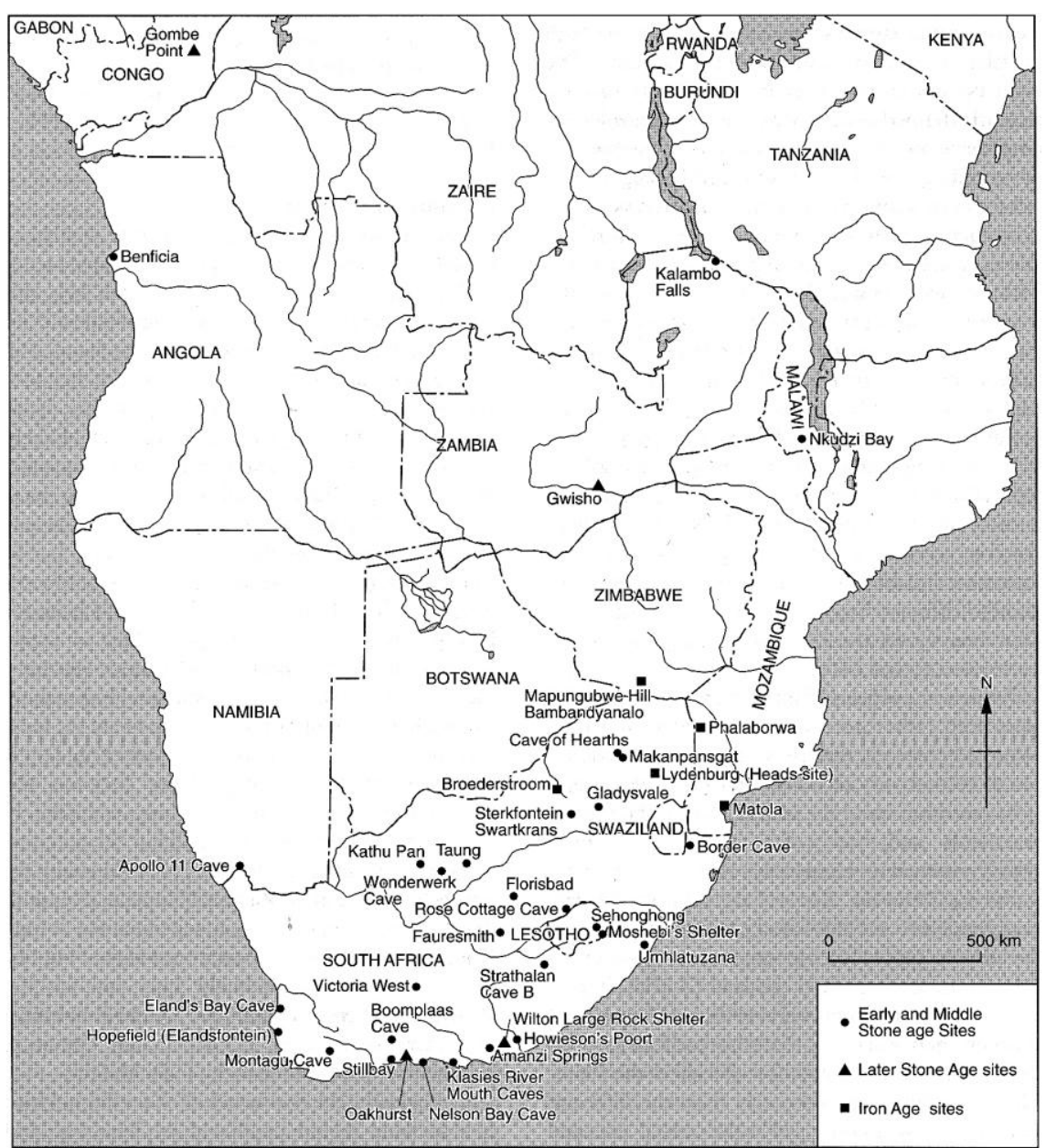

Fonte: SHAW e JAMESON (2002, p.24) 
A quinta e última fase é marcada pelo desenvolvimento da corrente pósprocessualista e pelo interesse nas relações sociais, nas ideologias e cosmologias fundadas nas etnografias constituídas junto aos grupos nativos, na arqueologia comunitária e histórica (Mitchell, 2002, p.37). Há uma ênfase nos estudos da interação entre comunidades com diferentes modos de vida e na aproximação das ciências arqueológica, antropológica e histórica.

Na perspectiva da Arqueologia Pós-Processualista e dos estudos póscoloniais, os posicionamentos dos arqueólogos da região são avaliados de duas formas, conforme Shepherd (2003, p.837):

i) Há aqueles que acusam parte dos arqueólogos sul-africanos de conluio com os governantes para ocultar a riqueza da herança précolonial por serem passivos ao regime segregacionista;

ii) Existem aqueles que destacam a resistência de parte dos arqueólogos sob o regime do apartheid.

Entretanto, na nossa interpretação sobre os editoriais do corpus documental, uma análise que coloca os posicionamentos dos arqueólogos classificados de modo binário não dá conta da complexidade das nuances da relação entre política e arqueologia.

Analisaremos de modo acurado, nos capítulos 4 e 7, a seguinte situação que trazemos como um exemplo dessa complexidade. Nos anos 1980, o regime segregacionista da África do Sul foi irreversivelmente abalado pelas revoltas das townships, a luta armada e a pressão dos sindicatos, das organizações religiosas e dos constantes boicotes internacionais. Em 1986, foram iniciadas as negociações para realizar a transição política com a participação de Nelson Mandela, preso político desde 1963. Ainda em 1986, os arqueólogos sul-africanos, vistos como passivos diante das atrocidades do regime segregacionista pelos organizadores do World Archaeological Congress (WAC) em Southampton (Inglaterra), foram desconvidados desse evento importante.

Essa situação pode ser considerada um boicote "bem-sucedido", orquestrado pelo conjunto de arqueólogos africanistas e africanos da 
organização do congresso em comparação ao boicote econômico pouco efetivo ao regime segregacionista. Em contrapartida, um número considerável de arqueólogos anglo-americanos considerou inaceitável a exclusão aos colegas sul-africanos e fizeram protestos veementes contra a situação que envolveu ciência e política.

De acordo com Shepherd (2003), entre os anos de 1987 e 2003, as universidades sul-africanas promoveram alterações significativas nos seus currículos, incluindo disciplinas as quais refletem sobre o papel da arqueologia nas transformações sociais e políticas. A mudança mais drástica refere-se à Antropologia que deixou de ser uma disciplina do apartheid, organizada em torno da ideia de raça, para privilegiar a noção de humanidade. Ocorreu também a fundação da National Research Foundation com muitos investimentos em novos modelos de pesquisa arqueológica, além de passar a receber investimento privado relacionado ao turismo cultural e à administração do patrimônio arqueológico.

Enfim, o processo de construção da imagem dos arqueólogos africanos e africanistas em meio a esse contexto histórico requer um olhar mais aprofundado com a análise do corpus documental. Os boletins TSAAB, NA e Nsi foram publicados pelas sociedades científicas, especificamente arqueológicas. Essas sociedades são consideradas nos editoriais como organizadoras do saber, dos códigos de conduta profissional e como portadoras da legitimidade de se pronunciar através de um código linguístico técnico e de temas que poucos africanos compartilham (FOUCAULT, 1972; HODDER, 1989; SHEPHERD, 2002). É o que veremos no próximo capítulo. 


\title{
3. AS SOCIEDADES CIENTÍFICAS E OS BOLETINS
}

\begin{abstract}
Quem, então, eram os homens que sustentavam as muitas sociedades históricas e arqueológicas do período, que exploravam os novos registros sistematizados do antigo governo, que publicaram campanologias [estudos de sinos] e histórias locais, cronologias e coleções, relatos de carrinho de escavação [...]? (LEVINE, 1986, p.78 - tradução livre $)^{38}$
\end{abstract}

Iniciamos esse capítulo tratando da terminologia que adotamos para referir-se ao corpus documental. A literatura constituída sobre comunicação científica toma o termo periódico científico ou revista científica reportando-se a um tipo de publicação seriada, contínua e numerada por volumes, números e anos que apresentam artigos de diversos autores, sendo respaldada por um corpo editorial (Fachin e Hillesheim apud FERREIRA, 2010). Por não identificarmos diferenças importantes na adoção dos termos, utilizaremos a expressão revista científica para fins de padronização ao tratar desse veículo.

Por outro lado, o termo boletim científico se refere a um tipo de publicação seriada, identificado pelos mesmos critérios, mas definido pela rapidez na divulgação das notícias da área científica. É também denominado Newsletter, no caso do Nyame Akuma (NA). O The South African Archaeological Bulletin (TSAAB) e o Nsi-Bulletin de Liaison des Archéologues du Monde Bantu, apesar de serem nomeados como boletins arqueológicos, não apresentaram no material analisado o apontamento da agilidade na exposição dos conhecimentos da área como característica essencial.

O papel principal desses três boletins é informar os pares sobre as pesquisas concluídas ou em andamento e os relatórios dos trabalhos de campo - uma função tradicional das revistas científicas (MIRANDA e PEREIRA, 1996). Estas se originaram no século XVII como uma nova forma de difusão que se realizava até aquele momento por um sistema particular de circulação de cartas sobre as descobertas, os procedimentos investigativos e o conteúdo das

\footnotetext{
${ }^{38}$ Who, then, were the men who sustained the many historical and archaeological societies of the period, who exploited the newly systematized records of past government, who published campanologies and county histories, chronologies and collections, accounts of barrow digging [...]? (LEVINE, 1986, p. 7-8)
} 
atas das reuniões dos cientistas. Suas primeiras edições conhecidas são: Journal des Sçavans que surgiu na França em 06 de janeiro de 1665, editado por Denis de Sallo e Philosophical Transactions of the Royal Society of London a qual apareceu na Inglaterra, em 06 de março de 1665 (STUMPF, 1996; SCHULTZE, 2005).

Hodder (1989), em um estudo sobre as mudanças na escrita das antigas publicações arqueológicas na Europa dos séculos XVIII a XX, destaca que os textos eram, basicamente, cartas trocadas entre os arqueólogos, as quais eram pontuadas por uma linguagem subjetiva e impregnadas de protagonismo. Paulatinamente, o estilo alterou-se com as mudanças na institucionalização da disciplina, na fundação e consolidação das sociedades arqueológicas e do público leitor de artigos científicos, no início do século $\mathrm{XX}$.

Se partir do século XVIII, o livro tornou-se um meio moroso, extenso e custoso para a publicação das descobertas e dos procedimentos da pesquisa, a revista científica, por sua vez, foi vista pelos cientistas como um meio veloz para publicar os resultados obtidos e, como consequência, permitir a sua ascensão em seu meio e a sua primazia sobre a descoberta (MIRANDA e PEREIRA, 1996). Apesar da antiguidade das revistas e dos boletins científicos, eles continuam desempenhando três funções segundo Oliveira (1996, p.81): "ser um meio de registro oficial e público da informação; atuar como meio de disseminação da informação; e, atribuir prestígio e reconhecimento aos autores e demais pessoas envolvidas no processo de comunicação da ciência." A identificação de suas funções na literatura especializada contribui para entender alguns aspectos dos editoriais do corpus documental na constituição das imagens dos arqueólogos africanos e africanistas.

Segundo J. Jaygbay apud Teferra (2004, p.161), em um conjunto de quarenta e oito países da África subsaariana, com exceção da África do Sul, existem, atualmente, cerca de quatrocentas revistas científicas, muitas das quais apresentando problemas na periodicidade, na definição da cobertura, pouca qualidade de produção, de layout e de edição. A pesquisa sobre problemáticas regionais da África e a não indexação são alguns dos fatores influenciadores da pouca visibilidade da produção científica do continente. As 
restrições financeiras de várias instituições de pesquisa incidem nas limitações do desenvolvimento e aprimoramento da divulgação científica africana.

Uma das iniciativas para aumentar a visibilidade das publicações seriadas foi feita pela Association of African Universities, Database of African Theses and Dissertation (DATAD) ${ }^{39}$, que possibilita a divulgação eletrônica das pesquisas acadêmicas africanas. O African Journals Online (AJOL) ${ }^{40}$, acessível deste 1998, foi financiado com recursos da UNESCO, da National Academy of Sciences dos Estados Unidos e da Norwegian Agency for Development Cooperation (NORAD) que, atualmente, disponibiliza mais de duzentos periódicos desse continente (TEFERRA, 2004).

O African Online Digital Library é resultado da parceria entre Michigan State University e o governo senegalês. O Memoria de África, um projeto da Fundação Portugal-África, iniciado em 1997 e renomeado em 2008 como Memoria de África e do Oriente $^{41}$, visa disponibilizar a localização e a digitalização dos acervos documentais dos países de língua portuguesa (PALOP). O African e-Journals Project (AEJP) é sediado na Michigan State University. Especificamente na África do Sul, é possível acessar o SABINET ${ }^{42}$, o Digital Imaging Project of South Africa ${ }^{43}$ e o projeto ALUKA ${ }^{44}$ (TEFERRA, 2004).

Apesar da diversidade das áreas do conhecimento cobertas por esses repositórios, de fato, grande parte das publicações disponibilizadas restringe-se as áreas da Saúde e das Ciências Biológicas. A ciência arqueológica, até o presente momento da pesquisa, fica "imperceptível" diante dessa cobertura.

De acordo com Robertshaw (1990), ao longo do período colonial, havia dificuldades para publicar os resultados das pesquisas arqueológicas sobre a África em revistas científicas. Aquelas que surgiram no século $\mathrm{XX}$, a maioria durante o Neocolonialismo, foram: South African Journal of Science (em

\footnotetext{
39 Disponível em: http://aau.org/datad/, acesso em 05/12/2012.

40 Disponível em: www.ajol.info, acesso em 05/12/2012.

41 Disponível em: http://memoria-africa.ua.pt, acesso em 05/12/2012.

42 Disponível em: http://www.sabinet.co.za/?page=electronic-journals-overview Acesso em 05/12/2012.

${ }^{43}$ Disponível em: http://www.disa.nu.ac.za, acesso em 05/12/2012.

${ }^{44}$ Disponível em: http://www.aluka.org/, acesso em 05/12/2012.
} 
meados do início do século XX), Bulletin de l'IFAN (1939), South African Archaeological Bulletin (1945), Kush (1953), Libyca (1953), West African Archaeological Newsletter (1963), Azania (1966-7), West African Journal of Archaeology (1971) e African Archaeological Review (1983) (ROBERTSHAW, 1990; GABEL, 1985). A diversidade de regiões abordadas por elas nos indica que a produção do conhecimento arqueológico especializou-se em temas e áreas geográficas. Atualmente, temos um grande volume de revistas científicas e boletins que podem ser considerados como documentos para a constituição de uma história da arqueologia africana e africanista.

Miranda e Pereira (1996), que descrevem os resultados de pesquisas sobre esses veículos, indicam que a maioria dos títulos vincula-se as sociedades científicas. Nessa perspectiva, os boletins, que são de responsabilidade dessas organizações, inserem-se em uma comunidade com ideias e funções definidas formalmente. Essa comunidade os produz e os consome.

Segundo Lannes (2010), a sociedade científica pode ser definida atualmente como:

[U]ma associação de especialistas de um ramo do conhecimento ou das ciências em geral que permite reunir-se, expor os resultados de suas pesquisas, confrontá-las com os de outros colegas especialistas do mesmo domínio do conhecimento -, e difundir seus trabalhos através de uma publicação especializada. (Lannes, 2010, p.1)

Essa acepção ainda carece de algumas considerações quanto aos tipos e aos papéis das sociedades científicas. Segundo Witter (2007, p.2) e Hahn (1971, p.3), essas instituições surgiram no século XVII, desde o estabelecimento da ciência "newtoniana", para suprir a necessidade de estabelecer procedimentos e comportamentos padrões na pesquisa, ampliar os contatos entre os pesquisadores, e, para além, era o espaço que consagrava o aceite dos pares à descoberta ou experimentação realizada, conferindo prestígio ao cientista. Para Hahn (1971): ciência era dependente tanto do surgimento de novos modelos de 
associação entre os homens da ciência quanto de estímulo para a sua elaboração. (HAHN, 1971, p.1-2 - tradução livre) ${ }^{45}$

Embora Hahn (1971) refira-se à gênese da The Paris Academy of Sciences (1666), consideramos essa perspectiva ao abordar as sociedades científicas SAAS, SAfA e CICIBA, enquanto "modelos de associações entre os homens da ciência" que ditam as imagens idealizadas dos arqueólogos africanos e africanistas, as novas metodologias e os novos conceitos ratificados pelos pares. Por sua vez, as sociedades científicas, através dos seus boletins, veiculam "a natureza do pensamento científico bastante abstrato dotada de um significado concreto evidenciando as práticas sociais generalizadas" (HAHN, 1971, p.2). Dessa forma, as sociedades analisadas nessa dissertação, diversificadas em tipos de associações regionais e internacionais, desempenharam papéis importantes na difusão do conhecimento arqueológico através dos artigos e, sobretudo, na reprodução e na crítica das práticas sociais estabelecidas pelo fenômeno do colonialismo entre os especialistas, através dos editoriais.

Segundo Hahn (1971, p.316), ser um membro de uma sociedade científica distingue o especialista perante outros profissionais "utilitários" da área como os "professores" e legitima o seu lugar de intelectual na sociedade civil. Nas palavras do autor, ser membro de uma sociedade significa mais do que um reconhecimento de um mérito intelectual, faz parte de uma forma de conceber a organização social e do trabalho. Levine (1986, p.11), que estuda a relação dos antiquários, arqueólogos e historiadores na Inglaterra no século $\mathrm{XIX}$, afirma que participar de uma comunidade científica "era frequentemente uma forma de melhora na mobilidade econômica e social". Consequentemente, com sua posição social de intelectual assegurada, somente o que os diferenciava eram os procedimentos para abordar o objeto de análise nas diferentes áreas.

Para fins de padronização da terminologia, intitularemos como sociedades científicas às sociedades arqueológicas que originaram os boletins

\footnotetext{
${ }^{45}$ The transmutation of the techniques, concepts, and methodologies of science was both dependent upon the emergence of new patterns of association among men of science and a stimulus to their further elaboration. (HAHN, 1971, p.1-2)
} 
especializados TSAAB, NA e Nsi, respectivamente a SAAS, a SAfA e o CICIBA.

$\mathrm{Na}$ Europa, no final do século XIX, o estudo da antiguidade da humanidade, realizado por arqueólogos, paleontólogos e geólogos, sofreu mudanças consideráveis com o estabelecimento de objetivos, métodos e interesses próprios das disciplinas. A institucionalização da arqueologia com uma identidade particular atrela-se a essa "normatização" disciplinar, à criação de museus e universidades e à formação das sociedades científicas (GOODRUM, 2009). Estas, especificamente as arqueológicas, surgiram como uma forma de regulação dos mecanismos de prestígio e de ascensão do arqueólogo associado e de estabelecimento de normas de conduta. De acordo com Levine (1986):

Como a arqueologia gradualmente emergiu como uma disciplina independente, ela abandonou suas associações com antiquarismo e construiu uma rede de homens, qualificados mesmo que não tivessem treinamento formal, familiarizados uns com os outros $e$ estabelecendo, pela primeira vez, as normas de conduta comuns para a disciplina. Os limites da comunidade arqueológica, até o final do século, efetivamente excluíram o antiquário. (LEVINE, 1986, p.35 - tradução livre) $)^{46}$

As primeiras sociedades científicas de arqueologia foram Congrès International d'Anthropologie et d'Archéologie Préhistorique (França, por volta de 1858), Berliner Gesellschaft für Anthropologie Ethnologie und Urgeschichte Sociedade Berlinesa de Antropologia Etnologia e Pré-história (Alemanha, 1869), entre outras relatadas por Goodrum (2009). Em 1870, essa sociedade alemã iniciou a publicação da revista Verhandlungen (“Negociações”). Em 1903, surgiu a Société Préhistorique de France a qual originou, no ano seguinte, o seu Bulletin. Em 1908, consolidou-se a Prehistoric Society of East Anglia que passou a divulgar, em 1911, a revista Proceedings.

Já, na África, em 1926, fundou-se, em Casablanca, a Société de Préhistorique du Maroc, cujo Bulletin começou a circular somente um ano

\footnotetext{
${ }^{46}$ As archaeology gradually emerged as an independent discipline, it shed its associations with antiquarianism and built up a network of men, skilled if formally lacking in training, familiar with one another and establishing for the first time communal standards of practice for the discipline. The boundaries of the community, by the end of the century, effectively excluded the antiquary. (LEVINE, 1986, p.35)
} 
depois (GOODRUM, 2009). O continente tornou-se alvo das sociedades científicas South African Archaeological Society (SAAS), Society of Africanist Archaeologists (SAfA) e Centre International des Civilisations Bantu (CICIBA) e de seus respectivos boletins arqueológicos, os quais construíram as imagens dos arqueólogos africanos e africanistas ao longo do século XX.

Além disso, o passado da África foi objeto dos intelectuais africanos e africanistas que fundaram sociedades culturais. Entre 1945 e 1965, os jovens e os intelectuais africanos, que estudavam em universidades na França e em Portugal, fomentaram a luta pela descolonização através dos ideais do panafricanismo. Longe do contato com familiares, políticos e da população questionaram a condição dos povos colonizados. Em 1947, em Paris, um grupo de intelectuais liderados pelo senegalês Alioune Diop lançou a Société Africaine de Culture (SAC) e a revista Présence Africaine, a qual agregou especialistas negros e brancos. Essa revista, tornada editora independente, oportunizou a divulgação dos trabalhos dos especialistas, cujas ideias se assentavam teoricamente no pan-africanismo e no papel da cultura na libertação dos povos africanos (M'BOKOLO, 2011, p.588, 589, 591-2). Um desses especialistas foi o senegalês Cheikh Anta Diop (1923-1986) que teve suas teses publicadas sobre o Egito faraônico negro e sobre a originalidade e anterioridade das civilizações africanas, sob os títulos de Nations Nègres et Culture (1954), L'Unité Culturelle de l'Afrique Noire (1960) e L'Afrique noire précoloniale (1960) (M'BOKOLO, 2011, p.590).

Segundo Shepperson (1962, p.346), o movimento pan-africanista teve como líder o intelectual afro-americano W.E.B. DuBois, o qual deu origem a alguns congressos pan-africanos ocorridos em: Paris (1919), em Londres (1921), em Londres e Lisboa (1923), em Nova lorque (1927), em Manchester (1945) e em Accra (1958). Este último teve grande repercussão, porque foi a primeira conferência de todos os povos africanos realizada no continente africano. Esse movimento, após alguns anos de maturação, cujas raízes precursoras encontram-se no século XIX, foi caracterizado pela exploração do conceito de unidade continental. Na reunião de Accra (1958), Kwame Nkrumah, primeiro-ministro de Gana, difundiu a ideia de unificação da África continental e das partes insulares, assentado na perspectiva da solidariedade dos 
afrodescendentes do mundo todo. Essa ideia, inicialmente, restringiu-se a um pequeno grupo de intelectuais (M'BOKOLO, 2011, p. 634).

$\mathrm{Na}$ segunda metade do século $\mathrm{XX}$, o projeto de um "renascimento africano" associado ao movimento pan-africanista expandiu tanto da área da cultura quanto da política e vimos a formulação de políticas culturais dos Estados nacionais independentes, enfatizando a pesquisa pan-africana. Foi o caso do Gabão e da criação da sociedade científica CICIBA. Por outro lado, o movimento pan-africano contrapunha-se ao desenvolvimento do apartheid na África Austral (Shepperson, 1962, p.352).

Segundo Early (1994), a especificidade do pensamento afro-centrista, contemporâneo ao pan-africanismo, é a crítica ao eurocentrismo acadêmico, à denúncia da supressão das expressões intelectuais não-ocidentais por parte dos acadêmicos eurocêntricos e a defesa da autodeterminação e da criatividade como premissa para o entendimento das realizações dos povos africanos. Essas críticas - aos temas e às metodologias eurocêntricas e à dificuldade de publicação dos intelectuais africanos no Ocidente - presentes no pensamento afro-centrista, foram identificadas por nós na literatura africana sobre a participação dos intelectuais africanos na área da arqueologia e, de modo geral, na produção do conhecimento científico (HOUNTONDJI, 1995 e 2008; MAMA, 2004; FOLORUNSO, 2007; BAGODO, 2004; HASSAN, 1999; KAREGA-MUNENE e SCHMIDT, 2010; BOULAGA, 1993; DIOUF, 1993; COPANS, 1993).

Cabe ressaltar que os boletins arqueológicos TSAAB, NA e Nsi são publicações de sociedades de âmbito regional e internacional, pois abrangem um vasto território de estudo e congregam arqueólogos africanos e africanistas. Logo, o estudo dos editoriais dos boletins realizados por nós intentou imergir no contexto dos anos de 1987 e 1993 avaliando:

i) A construção das imagens dos arqueólogos africanos e africanistas;

ii) A trajetória do pensamento sobre a participação social dos arqueólogos africanos e africanistas; e 
iii) A relação dos arqueólogos com a sociedade civil na gestão do patrimônio arqueológico.

As sociedades científicas são, a priori, os espaços de produção e difusão do conhecimento arqueológico registrado em uma linguagem técnica. Segundo Hodder (1989):

No século $X X$, o poder na comunidade arqueológica tem sido disperso. Ele reside nas instituições e no espaço público. (...) Para dispersar o conhecimento sobre o passado dentro de um código abstrato, impessoal e objetivo era necessário dispersar o poder e a autoridade baseada na tradição. (HODDER, 1989, p.272 - tradução livre) $)^{47}$

O diálogo com os amadores e pesquisadores de outras áreas complexifica o papel dessas sociedades entre os anos de 1987 e 1993. A corrente da Nova Arqueologia, nas décadas anteriores, contribuiu para institucionalizar e profissionalizar a disciplina e, portanto, aprofundou a separação dos grupos produtores de conhecimento: os profissionais dos amadores. A forma como os editoriais apresentam os grupos produtores de conhecimento depende de como as estruturas de poder das sociedades científicas estão estabelecidas (LEVINE, 1986; HAHN, 1971).

Por outro lado, segundo Hodder (1989), a escrita da ciência arqueológica impôs-se como um código específico da disciplina, na medida em que o Estado tornou-se responsável por proteger o passado da nação. Fato este que ocorre ainda no final do século $X X$, quando consideramos a quantidade de editoriais que tratam de gestão do patrimônio arqueológico e de assuntos correlacionados (cf. gráficos nove e dez).

Entre as décadas de 1960 e 1980 houve, segundo o Hodder (1989), a consolidação da atual forma de escritura dos artigos de arqueologia, de caráter impessoal e codificado. Eis o porquê dos editoriais selecionados aparecerem com diversas linguagens dentro do mesmo boletim, porém, atinge o público de uma forma específica, contribuindo para reificar o poder da sociedade científica. Também apresentam algumas especificidades. Enquanto que a escrita da ciência arqueológica nos artigos pode ser reconhecida pelo

\footnotetext{
${ }^{47}$ In the 20th century, power in the archaeological community has been dispersed. It resides in institutions and in the public space. (...) To disperse knowledge about the past within an abstract, impersonal and objective code was to disperse the power and authority based on tradition. (HODDER, 1989, p.272).
} 
distanciamento, pelo jargão, pela objetividade e a pela impessoalidade - enfim, uma linguagem codificada ininteligível para leitores comuns - os textos editoriais são a oposição disso, visto que é o local de escape da subjetividade do editor-arqueólogo, o qual se apropria dos códigos de linguagem e de conduta das sociedades arqueológicas como legitimador da sua opinião (HODDER, 1989, p.268, 271; SHEPHERD, 2002, p.198; TILLEY, 1989, p.278).

Logo, os editoriais dos boletins arqueológicos são suportes de discursos tensos, derivados das dificuldades de definir os limites da atuação social e política dos arqueólogos associados à SAAS, a SAfA e ao CICIBA. Nessa situação, realizar um estudo sobre as demandas das diferentes sociedades científicas publicadoras entre os anos de 1987 e de 1993 visa reconstituir, na perspectiva dos editoriais, as imagens dos arqueólogos africanos e africanistas nesse contexto histórico. Nos capítulos subsequentes examinaremos a missão dessas instituições com poderes de organizarem o conhecimento, produzirem 0 consenso e os veicularem através dos boletins e, especificamente, dos editoriais.

Para esse intento baseamos-nos na metodologia de Foucault (1972) para analisar os editoriais enquanto práticas discursivas constituintes do objeto "arqueólogo" africano e africanista. O autor definiu alguns princípios da sua metodologia os quais consideramos durante a análise. Considerando esses princípios, os editoriais são práticas discursivas que devem ser tratados em sua especificidade, qual o "jogo de regras" que apresentam e buscamos as especificidades que extrapolam 0 âmbito da sua autoria individual (FOUCAULT, 1972, p.171-173, 178, 198). 
PARTE II - ANÁLISE DOS EDITORIAIS 


\section{THE SOUTH AFRICAN ARCHAEOLOGICAL BULLETIN}

Um recém-chegado à arqueologia sul-africana não pode fazer pior do que examinar as antigas edições do The Southern [sic, South] African Archaeological Bulletin. (SHEPHERD, 2000, p.149) ${ }^{48}$

\section{A Sociedade e o Boletim}

The South African Archaeological Bulletin (TSAAB) é publicado semestralmente nos meses de junho e dezembro e foi lançado em dezembro de 1945, como uma das publicações da South African Archaeological Society (SAAS) sediada na África do Sul. Segundo Gabel (1985, p.254): "Por mais de vinte anos o South African Archaeological Bulletin foi o único periódico do continente dedicado exclusivamente à arqueologia." (tradução livre) ${ }^{49}$. Somente em 1967 surgiu a revista Azania do British Institute in Eastern Africa e, em 1971, circulou a West African Journal of Archaeology, a qual foi precedida pela West African Archaeological Newsletter (1963-1970) (GABEL, 1985, p.260).

Atualmente o TSAAB continua a ser editado, porém, desde 2005, pela Association of Southern African Professional Archaeologists (ASAPA). O nosso corpus documental é composto de 34 editoriais, entre os quais 14 são provenientes do TSAAB, que serão analisados nesse capítulo.

Inicialmente, desde o primeiro número até o ano de 1959 foi editado por Astley John Hilary Goodwin, chefe do Departamento de Arqueologia da University of Cape Town. Segundo o editor Goodwin (1945), o boletim, assim como outra publicação da sociedade - The Handbook Series, eram produtos da reestruturação da Cape Archaeological Society, a qual foi renomeada posteriormente para South African Archaeological Society. A ideia de fundar uma sociedade arqueológica na África do Sul foi concebida em uma reunião em sua casa em 09 de agosto de 1944 pelo geógrafo e botânico Eric A. Nobbs,

\footnotetext{
${ }^{48}$ A newcomer to South African archaeology might do worse than scan the back issues of The Southern [sic South] African Archaeological Bulletin. (SHEPHERD, 2000, p.149)

${ }^{49}$ For over twenty years, the South African Archaeological Bulletin was the only periodical in the continent devoted wholly to archaeology. (GABEL, 1985, p.254)
} 
por H.S. Jager - arqueólogo amador estudioso dos sítios do Fish Hoek Valley e prefeito do município de Fish Hoek - e pela linguista Dorothea Frances Bleek, filha do também linguista Wilhelm H.I. Bleek, citado no capítulo dois. A Cape Archaeological Society surgiu com a meta de congregar cerca de trinta membros e atuar na Província do Cabo (MALAN, 1955; TSAAB, 1963).

O grande afluxo de membros e as solicitações do general Smuts e do arqueólogo Van Riet Lowe para aumentar a área de interesse da Cape Archaeological Society resultou nas reuniões de 08 de maio e de 05 de junho de 1945, nas quais foi renomeada para South African Archaeological Society. O estatuto da SAAS foi escrito por Goodwin e por A. W. Robinson, prevendo uma sede central e seis sucursais em diferentes regiões da África do Sul.

Seis meses depois da refundação da sociedade, o TSAAB começou a circular tendo como conteúdo artigos originais com ilustrações, conforme apresenta Malan (1955). Temos como exemplos a figura três sobre a divisão cronológica da antiguidade da África Austral, inserido no capítulo dois, e a figura cinco, logo abaixo, onde consta a reprodução da capa do TSAAB com a cópia de uma pintura rupestre e da logomarca do editorial. Além das ilustrações continha pesquisas, revisões bibliográficas, relatos das atividades das sucursais, cartas, obituários, notícias e o editorial (MALAN, 1955). 
Figura 5 - Capa e parte do editorial do primeiro número do TSAAB, dezembro de 1945.

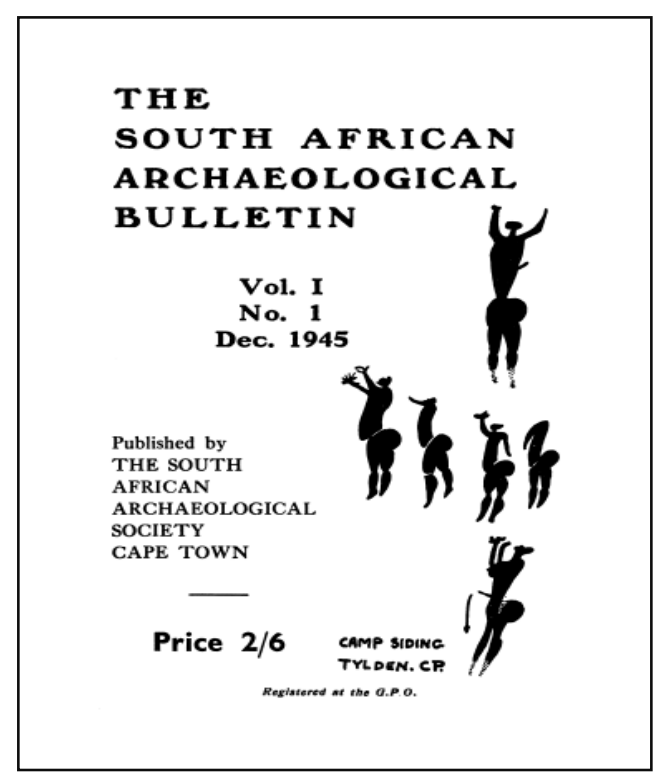

Fonte: JSTOR a, acesso em 03/11/2012.

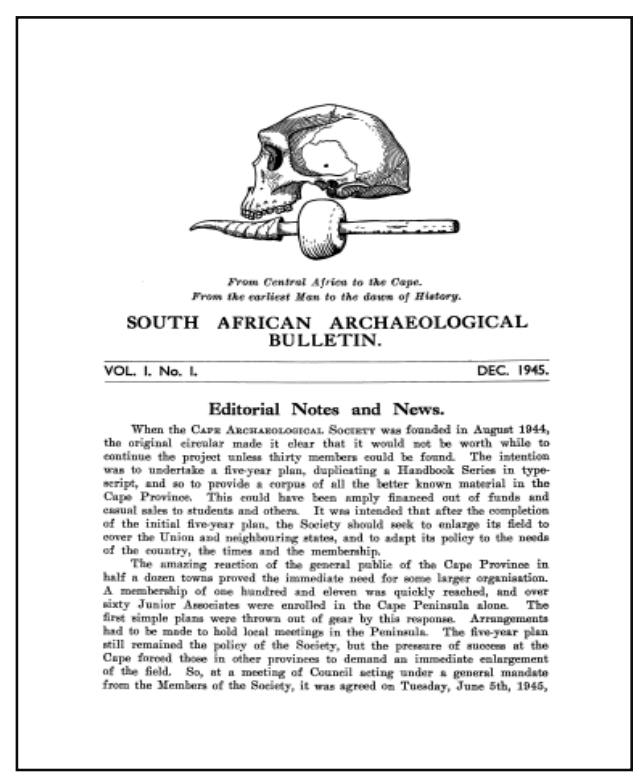

Fonte: JSTOR b, acesso em 03/11/2012.

As capas do boletim são dignas de um estudo específico sobre a cópia da arte rupestre que não cabe nessa dissertação. Seu tema é, principalmente, gravuras e pinturas rupestres, cuja proteção é um tópico dos editoriais. Tratase de reproduções das pinturas e gravuras rupestres realizadas por arqueólogos especialistas e amadores. Algumas capas do nosso corpus documental foram comentadas nos editoriais. É o caso das de junho de 1987 com a representação de uma imagem localizada em uma fazenda em 1983; de junho de 1988; de dezembro de 1990, com as ilustrações copiadas pelo artista local "Ginger" Townley Johnson em 1974 e em 1976; de dezembro de 1988; de dezembro de 1989, com os desenhos reproduzidos pelo Prof. Murray Schoonraad; de junho de 1989; e, de junho de 1992, com a reprodução da arte rupestre copiada por Thomas Dowson da Rock Art Research Unit.

Goodwin, em março de 1946, explica a escolha da logomarca do TSAAB - o crânio e a ferramenta disposta abaixo dele:

O crânio é o famoso Crânio Broken Hill, Homo rhodesiensis, do espécime Homem Rodesiano. [...] Ele representa o homem arcaico, o mais primitivo de qualquer um dos homens encontrados até agora na África. [...] Sob o crânio encontra-se uma ferramenta de escavação. [...] A pedra furada disposta sobre a ferramenta de escavação 
calçada com o chife de bode, é típica do Cabo e de áreas mais ao norte. (GOODWIN, 1946c, p.30 - tradução livre) ${ }^{50}$

Esse crânio, também denominado Kabwe cranium, foi localizado em 1921, em uma mina de zinco na Rodésia do Norte, atual Zâmbia. Foi o primeiro fóssil antigo encontrado na África. O achado causou um grande impacto nos estudos antropológicos e de evolução humana na primeira metade do século XX. Atualmente encontra-se no British Museum em Londres. Constatou-se ser do espécime Homo heidelbergensis, sendo datado entre 100.000 e 300.000 anos atrás (GABEL, 1985, p.255; ENCYCLOPEDIA BRITANNICA ACADEMIC EDITION, acesso em 17/11/2012).

A SAAS preocupou-se com os leigos ao divulgar um material de difusão como a coleção Goodwin Series, um Newsletter (1978) e a publicação seriada The Digging Stick (1984). Desde o ano de 2005, essa sociedade deixou de publicar o TSAAB, mas continua a atuar enquanto uma instituição de interessados em arqueologia. A sociedade científica responsável pelas edições do boletim desde então é a Association of Southern African Professional Archaeologists (ASAPA), fundada por Ray Inskeep, em 1971, com o antigo nome de Southern African Association of Archaeologists (SA3), conforme consta em THE SOUTH AFRICAN ARCHAEOLOGICAL SOCIETY a, acesso em 03/11/2012.

Atualmente a SAAS possui sucursais organizadas por membros voluntários associados nas cidades sul-africanas de Gauteng - a sucursal Trans-Vaal, Cape Town - a Western Cape, Durban/Pietermaritzburg - a KwaZulu-Natal e Kimberley/Bloemfontein - a Trans-Garib!

O processo de renomear a sociedade Cape Archaeological Society, em 09 de agosto de 1944, para South African Archaeological Society, em 05 de junho de 1945, precisa de mais considerações, a fim de podermos compreender as raízes da relação entre arqueologia, política e sociedade na

\footnotetext{
${ }^{50}$ The skull is the famous Broken Hill skull, Homo rhodesiensis, type specimen of Rhodesian Man. [...] He represents archaic man, the most primitive development of any of the men so far found in Africa. [...] Under the skull is a digging-stick. [...] The bored Stone, set on a digging-stick shod with buck-horn, is typical of the Cape and areas further North. (GOODWIN, 1946c, p.30)
} 
África do Sul, que respaldaram a nossa análise do corpus. Para isso, retomamos o ano de 1910.

A União da África do Sul, fundada nesse ano, assentava-se em uma política regional de expansão econômica e na anexação de partes dos territórios da África Central e Austral visando formar uma "União Maior". O grande promotor dessa política da "Greater Union" era o General Jan Smuts que vislumbrava a incorporação dos territórios do norte de Moçambique e de Angola à União Sul-Africana. Em 1923, houve a tentativa frustrada de vincular a Rodésia do Sul e os Territórios do Alto Comissário, atual Botswana, Lesotho e Suazilândia (DÖPCKE, 1998, p.135).

A África do Sul esteve sob a esfera de influência da Inglaterra na chamada Commonwealth estabelecida pelo Estatuto de Westminster de 1931, compondo-a, juntamente, com as "colônias brancas" Canadá, Austrália e Nova Zelândia e as antigas colônias britânicas. Essa estratégia era uma tentativa da Inglaterra de conter seu expansionismo, que ainda assim, avançou sobre a Namíbia (DÖPCKE, 1998, p.135). Entre os anos de 1939 e 1945 a Segunda Guerra Mundial eclodiu na Europa com ramificações no continente africano. Durante o conflito, os alemães viram os boêres ou africâners como aliados em potencial, percepção justificada por uma pretensa origem comum, por sua adesão à política segregacionista, um dos "temas de Hitler", e pelo difícil entendimento entre aqueles e as elites e classes médias sul-africanas partidárias dos britânicos (M'BOKOLO, 2011, p.558).

Em 09 de agosto de 1944, a sociedade Cape Archaeological Society foi idealizada para abranger os estudos de arqueólogos amadores e profissionais da Província do Cabo, incluindo as atuais províncias Northern Cape, Western Cape e Eastern Cape (ver mapa sete). As solicitações do General Smuts, "mecenas" da arqueologia local, para alargar a cobertura da sociedade fariam sentido na política expansionista da África do Sul.

A definição do final da guerra com a derrota alemã, as preocupações dos britânicos com a reconstrução da metrópole e a fraca contenção dessa política expansionista sul-africana pela Grã-Bretanha estimulou os "olhares sulafricanos" para as colônias e, posteriormente, para os países independentes da 
África Austral e Central. Nesse sentido, poderíamos interpretar a afirmação de Goodwin (1945, p.2 e 4), transcrita mais adiante, de que o TSAAB seria publicado em língua inglesa como uma vitória dos partidários da influência britânica na África do Sul sobre os bôeres ou africâners, com os quais disputavam poder. Lembrando que em 1948, ocorre a eleição de Daniel François Malan apoiado pela plataforma política do apartheid, a qual congregava grupos insatisfeitos com a política de Smuts.

Em 05 de junho de 1945, a sociedade foi renomeada para South African Archaeological Society

[...] com princípios e intencões inalterados, mas que abrange uma área mais ampla, incluindo a União [Sul-africana] e os estados vizinhos (p. ex. Rodésia do Sul, Suazilândia, Sudoeste Africano [Namíbia], etc) como poderia ser do interesse.(GOODWIN, 1945, p.2 - tradução livre, grifos nossos) ${ }^{51}$

A última expressão grifada "como poderia ser do interesse" foi interpretada diferentemente por Malan (1955). Na edição comemorativa dos dez anos do TSAAB, o autor cita, entre aspas, a decisão do Council of the Cape Archaeological Society, na reunião de 08 de maio de 1945, intentando justificar a renomeação da sociedade:

[...] para explorar a questão do alargamento do escopo da presente Sociedade para cobrir a África Austral, incluindo a Rodésia do Sul e aqueles territórios vizinhos que têm um vivo interesse no assunto, com poder para agir. (MALAN, 1955, p. 32 - tradução livre, grifos nossos) $)^{52}$

Em que pese às diferenças de expressões utilizadas por Goodwin (1945) e Malan (1955), destacamos o envolvimento dos arqueólogos profissionais e amadores da África do Sul nos desdobramentos da política expansionista governamental. O mecenato do General Smuts, agradecido publicamente por Goodwin em seus editoriais, possibilitou aos seus arqueólogos o financiamento e o acesso facilitado aos sítios arqueológicos na África Austral. Isso é explícito,

\footnotetext{
${ }^{51}[\ldots]$ with unchanged principles and intentions, but covering a wider area, including the Union and such neighbouring states (e.g. Southern Rhodesia, Swaziland, Southwest Africa, etc) as might be interested (GOODWIN, 1945, p.2).

52 " [...] to explore the question of widening the scope of the present Society to cover southern Africa, including Southern Rhodesia and those neighbouring territories which have a lively interest in the subject, with power to act." (MALAN, 1955, p. 32)
} 
décadas depois, nos sumários das edições do TSAAB que abrangem estudos de uma grande área geográfica coincidente com os países sob a hegemonia da África do Sul nessa região do continente. A decisão do conselho da sociedade pelo seu renomeamento pode estar ligada a um fato que irá marcar a arqueologia sul-africana nas décadas subsequentes, segundo Shepherd (2000, p. 146), o beneficiamento dos arqueólogos dos governos sul-africanos e o inverso. Sob nosso ponto de vista, as consequências dessa situação aparecem implicitamente nos editoriais do nosso corpus.

Retomando as publicações da SAAS, a coleção The Handbook Series foi divulgada como uma "enciclopédia da arqueologia na África do Sul", criada para sistematizar o conhecimento da área, produzido pelos membros da sociedade, já

[a] função do boletim é muito diferente. É instrutivo, e será escrito, tanto quanto for possível, em uma linguagem que pode ser imediatamente compreendida. [...] No caso dos Handbooks, vamos pedir às pessoas adequadas para realizar o trabalho necessário. Em oposição, 0 boletim destina-se a contribuições individuais. (GOODWIN, 1945, p. 2 e 4 - tradução livre, grifos do editor) ${ }^{53}$

Nesse primeiro editorial da TSAAB, datado de dezembro de 1945, o editor Goodwin apontou os intentos do boletim: divulgar as pesquisas arqueológicas em andamento, publicar os artigos que revisem as evidências científicas para os arqueólogos associados, para os amadores e para os leitores oriundos das classes médias sul-africanas. Os artigos selecionados para a publicação eram contribuições gratuitas dos membros para informar e educar o público-leitor leigo. As palavras grifadas do editor são fundamentais, já que o boletim atua no condicionamento do pensamento e das ações do receptor.

Atualmente, a SAAS possui objetivos parecidos com aqueles do primeiro editorial, disponíveis para consulta em seu endereço eletrônico:

I. Estimular e fomentar o interesse e o apoio ao estudo da arqueologia e da pesquisa arqueológica;

\footnotetext{
${ }^{53}$ The function of the Bulletin is very different. It is instructive, and will be written, so far as is possible, in language that can be readly understood. [...] In the case of Handbooks, we shall ask suitable persons to undertake the necessary work. In contrast, the Bulletin is intended for individual contribution. (GOODWIN, 1945, p. 2 e 4).
} 
II. Promover a educação de adultos por meio de palestras, seminários, cursos e excursões sob orientação profissional;

III. Publicar relatórios e outras publicacões em arqueologia e construir e manter uma biblioteca para o uso de membros.

IV. Conservar ou resgatar, ou contribuir para a conservação ou recuperação de sítios arqueológicos terrestres e marinhos, artefatos, coleções ou registros;

V. Cooperar com outras entidades e indivíduos em estudos e pesquisas arqueológicas e multidisciplinares;

VI. Ampliar ou contrair empréstimos, adquirir ou alienar quaisquer propriedades e fazer tudo que possa promover 0 cumprimento dos objetos acima.

(Fonte: SOUTH AFRICAN ARCHAEOLOGICAL SOCIETY b, acesso em 03/11/2012 - tradução livre, grifos nossos) ${ }^{54}$

Na primeira metade do século XX, em seus artigos, Goodwin mostrava preocupação com os leitores leigos. Essa apreensão foi percebida na divulgação da nova terminologia da antiguidade da África Austral. Ao elencar as oito condições para a aceitação dos termos criados por Van Riet Lowe e pelo editor para os períodos da "pré-história" da região, conforme discutido no capítulo anterior, Goodwin (1946b) destaca:

5. [A terminologia] deve ser simples na acepção: um conjunto representativo de ferramentas de uma cultura singular deve ser reconhecível pelo mais leigo como pertencendo a uma ldade adequada, mesmo que [esse conjunto] não possa ser classificado culturalmente. [...] 8. [A terminologia] deve ser consistente: se saltarmos de um sistema de terminologia para outro atrapalhará o leigo. [...] A terminologia é 'entendida pelo povo', e o que é mais importante, o sistema funciona. (GOODWIN, 1946b, p.94 - tradução livre, grifos do autor) ${ }^{55}$

\footnotetext{
${ }^{54}$ The objectives of the Society are to:

I. encourage and foster interest in and support for the study of archaeology and archaeological research; II. promote adult education by way of lectures, seminars, educational courses and excursions under professional guidance; III. publish reports and other literature on archaeology and build up and maintain a library for use of members; IV. conserve or rescue, or assist in the conservation or rescue of, terrestrial and marine archaeological sites, materials, collections or records; V. co-operate with other bodies and individuals in archaeological and multidisciplinary studies and research; VI. raise or borrow funds, acquire or dispose of any property and do all such other things as may promote the fulfilment of the above objects. (Fonte: SOUTH AFRICAN ARCHAEOLOGICAL SOCIETY b, acesso em 03/11/2012).

55 . It should be simple in connotation: a representative assemblage of tools from a single culture should be recognizable as belonging to the appropriate Age by the veriest layman, even if it cannot be classified culturally. 8. It should be consistent: jumping from one system of terminology to another is muddling to the layman. The terminology is 'understanded of the people', and what is more important, the system works. (GOODWIN, 1946b, p. 94)
} 
Além disso, temos no sul uma terminologia completa [discutida no capítulo dois], desenvolvida ao longo de anos, que se encaixa adequadamente na África Austral, e é compreendida por centenas de estudantes de pré-história, principalmente os amadores. (GOODWIN, 1946 b, p.97- tradução livre, grifos do autor $)^{56}$

Os membros fundadores da SAAS eram interessados em arqueologia, em grande parte, profissionais que pertenciam a uma elite sul-africana educada, mas leiga em relação ao jargão e aos procedimentos arqueológicos. Isso podia ser um dos fatores da preocupação do editor do TSAAB em relação a uma nomenclatura acessível aos leitores do boletim. Como um indicativo dessa situação, citamos alguns dos "leigos" fundadores da sociedade entre os 247 integrantes: o comandante H. S. Gracie e o capitão R. E. Helme - ambos membros vitalícios e doadores; o juiz Allan Mossop - membro vitalício; o senador D.H. van Zyl; o major J.C. Smuts - membro vitalício; o reverendo J. Wesley Hunt; o advogado H.F. Sampson; o arquidiácono C.W. Alderson doador; entre outros majores, capitães e reverendos.

Ainda somam-se os membros institucionais, como: a Companhia de Diamantes de Angola; a sociedade Bristol and Gloucester Archaeological Society da Inglaterra; os museus Rhodes-Livingstone Museum da Rodésia do Norte; Peabody Museum of Archaeology and Ethnology e American Museum of Natural History, ambos dos Estados Unidos; e as universidades University of California dos Estados Unidos e Witwatersrand University da África do Sul. Além de outras instituições sul-africanas (TSAAB, 1946; MALAN, 1955). Ao lado do nome do Peabody Museum of Archaeology and Ethnology, dos Estados Unidos, aparece a palavra "exchange" entre parênteses, significando "troca", que poderia ser um indicativo do intercâmbio de especialistas, de concepções teóricas e da permuta de artefatos entre a SAAS e o museu norteamericano para a formação de coleções arqueológicas.

Apesar dessa preocupação com a compreensão do público leigo em relação aos termos e temas da arqueologia, o editor Goodwin era cioso da linguagem empregada no boletim. Segundo M'Bokolo (2011, p. 542 e 544), desde o século XIX, os sistemas escolares implantados nas colônias britânicas,

\footnotetext{
${ }^{56}$ In addition we have in the south a complete terminology, developed over a series of years, which fits southern Africa adequately, and is understood by some hundreds of students of prehistory, mainly amateur. (GOODWIN, 1946b, p. 97)
} 
francesas, belgas, portuguesas e espanholas foram determinantes na formação de um tipo de elite que prezava o cultivo dos sinais de europeidade, sendo eles visíveis na comunicação escrita e verbal refinada na língua do colonizador para distinguir-se da massa de incultos. Goodwin, indicando esses sinais de europeidade, escreve no primeiro editorial do TSAAB, datado de dezembro de 1945:

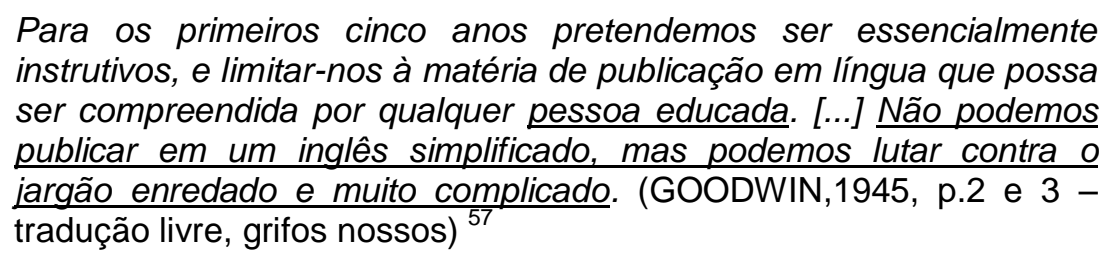

O TSAAB, como produto da SAAS, tinha uma função primariamente instrutiva das elites sul-africanas cultas, formadas por boêres ou africâners, descendentes de holandeses e por britânicos e seus descendentes, em meados do século $X X$, em um período conturbado imediatamente após a Segunda Guerra Mundial. Somente em 1961, foi proclamada a saída da África do Sul da Commonweath britânica, em referendo. A partir disso, uma sucessão de boicotes econômicos, políticos e culturais foram estabelecidos ao Estado pela ONU e sancionados por diferentes países.

Perguntamo-nos se as estratégias e temas da instrução das elites, presentes no primeiro editorial do TSAAB, de algum modo, foram recorrentes nos editoriais dos anos 1987 e 1993? Quais as imagens dos arqueólogos africanos e africanistas construídas pelos seus editores e difundidas pelos seus editoriais como publicação da South African Archaeological Society (SAAS)?

Para responder a esses questionamentos nos direcionaremos para a análise do corpus documental e depois conheceremos a editora principal, Janette Deacon, e os editores convidados do boletim TSAAB. Essa "inversão" deve-se a metodologia empregada nessa dissertação, já discutida no capítulo um, a qual parte da análise dos enunciados e dos temas das fontes documentais selecionadas para o que se pretende.

\footnotetext{
${ }^{57}$ For the first five years we intend to be primarily instructive, and to confine ourselves to publishing matter in language that can be understood by any educated person. [...] We cannot publish in a simplified English, but we can fight against embroiled and over-complicated jargon. (GOODWIN,1945, p.2 e 3)
} 
Queremos com essa apreciação identificar os tipos imagéticos dos arqueólogos africanos e africanistas construídos em um conjunto de editoriais desse boletim. Não é nosso propósito partir da vida dos editores para daí estabelecer o percurso da análise, mas sim o contrário. Nós buscamos partir das fontes para situar as imagens dos arqueólogos difundidas pelos editores vinculados à SAAS e daí compreender sua função.

\section{Os editoriais e os editores}

Em junho de 1987, Deacon escreve:

A política dos arqueólogos tem sido recomendar ao National Monuments Council e o Tourism Board para não revelar a localização dos sítios de arte rupestre, porque, é uma triste verdade que, uma vez que um sítio de pintura entra em uma rota turística, seus dias estão contados. Gostaríamos de incutir em todos os nossos cidadãos um sentimento de orgulho e carinho para nos permitir mostrar as pinturas e as gravuras para os nossos netos e bisnetos. Não molhe ou toque pinturas rupestres, e nunca tente tocar ou rabiscar sobre gravuras rupestres. É o pior tipo de vandalismo. Trate todo tipo de arte rupestre como se você estivesse no Louvre e seja grato por você não ter que pagar o ingresso. (TSAAB, junho 1987, vol.42, n.145, p.3 - tradução livre, grifos nossos) ${ }^{58}$

O primeiro editorial da TSAAB do nosso corpus documental nos indica o tom da abordagem relacionada à instrução dos leitores em educação patrimonial. O enunciado "Não molhe ou toque pinturas rupestres, e nunca tente tocar ou rabiscar sobre gravuras rupestres" é uma expressão imperativa que apresenta uma linguagem de fácil compreensão, denotando o direcionamento do editor para o leitor, que pode ser leigo no jargão e nos procedimentos arqueológicos.

O enunciado "Trate todo tipo de arte rupestre como se você estivesse no Louvre" caracteriza ainda mais esse leitor leigo, aquele que tem acesso ou minimamente conhece o Musée du Louvre, situado em Paris. Portanto,

\footnotetext{
${ }^{58}$ It has long been the policy of archaeologists advising the national Monuments Council and the Tourism Board not to disclose the whereabouts of rock sites because it is the unhappy truth once a painted site is on a tourist route, its days are numbered. We should like to instill in all our citizens a feeling of pride and caring to enable us to show the paintings and engravings to our grandchildren and great grandchildren. Do not wet or touch rock paintings, and never try to touch up or scribble over rock engravings. It is the worst kind of vandalism. Treat all rock art as if you were in the Louvre and be thankful you do not have to pay the entrance fee. (TSAAB, June 1987, vol.42, n.145, p.3)
} 
supomos que esse indivíduo ainda faça parte de uma elite da África do Sul, como no ano de 1945. Já foi dito anteriormente que alguns sinais de europeidade dos leitores e dos autores foram citados no editorial de lançamento do TSAAB, como, por exemplo, a comunicação escrita refinada na língua inglesa, mas sem o jargão arqueológico. Não apenas isso volta a aparecer nesse enunciado de junho de 1987.

O comportamento no Louvre, tido como referência para essa editora preocupada com a preservação do patrimônio arqueológico, nos indica que o leigo deve ter uma postura "ocidental" de bom observador: não molha, não toca, não rabisca ou não retoca, diferentemente da conduta da população autóctone a qual tem uma relação ativa com o patrimônio arqueológico. Abaixo transcrevemos um trecho da análise de Ndlovu (2005) sobre esse tipo de raciocínio de Deacon e das autoridades sul-africanas que transparece nos editoriais do corpus referentes à gestão do patrimônio arqueológico:

\begin{abstract}
A abordagem atual da gestão da arte rupestre é muito "hierarquizada" e preservacionista. Na maioria dos casos, as experiências têm-nos mostrado que o que é percebido como "gestão" no sentido ocidental não é realmente "gestão" no sentido africano. Os paradigmas são baseados em diferenças fundamentais, com diferentes prioridades, que podem levar a confrontos sérios. $A$ abordagem das autoridades para uma determinada área é impor controle sobre a gestão dos sítios e das pessoas, a fim de impedir o que eles vêem como vandalismo. Os povos indígenas e os povos de língua bantu relacionam-se com os sítios de forma diferente, porque eles os consideram significativos. A prioridade da gestão do patrimônio de acordo com a abordagem ocidental é manter as coisas como elas estão, sem fazer quaisquer alterações. A principal prioridade é, portanto, preservar os artefatos e os lugares como obras de arte originais a serem admiradas por todos. De acordo com a abordagem africana, a gestão não estaria apenas interessada em manter a arte rupestre como um trabalho artístico original para ser admirado, mas estaria também interessada na gestão espiritual do sítio. De acordo com os defensores desta prática, as pessoas devem sentir a força espiritual ao visitar um sítio de arte rupestre considerado sagrado para eles, e para isso acontecer, as atividades rituais devem sobrevir, e, em alguns casos, as ofertas precisam ser feitas. Estas atividades, em alguns casos, podem ser "prejudiciais" às pinturas em si, mas ao contrário do entendimento ocidental, o foco seria mais na gestão espiritual. (NDLOVU, 2005, p.20* - tradução livre - grifos nossos) ${ }^{59}$
\end{abstract}

\footnotetext{
*Páginas sem numeração. Seguimos a paginação apontada no texto original no arquivo em extensão "pdf".

59 The current approach to rock art management is very 'top-down' and preservationist. In most cases, experiences have shown us that what is perceived as 'management' in a Western sense is not really management in an African sense. The paradigms are based on fundamental differences, with different
} 
Embora Ndlovu (2005), empregue a palavra "atual" para tratar de uma situação do início do século XXI, consideramos que a abordagem ocidental da gestão do patrimônio da arte rupestre está presente nos editoriais analisados no período de 1987 e 1993. A fim de constatar essa consideração, analisemos o próximo editorial. Em dezembro de 1987, seis meses depois, a editora Janette Deacon, festejando o aumento da tiragem dos folhetos educativos sobre proteção da arte rupestre distribuído pelo TSAAB, denuncia o que foi considerado um mau comportamento:

Pessoas [comunidades] egoístas e individualistas estão removendo gravuras dos seus locais de origem destruindo, assim, as associações arqueológicas e artísticas para sempre. (TSAAB, dez. 1987 , vol.42, n.146, p. 86 - tradução livre) ${ }^{60}$

A denúncia contida nesse editorial relaciona-se a uma forma das pessoas ou comunidades interagirem com a herança arqueológica que, pelo retoque ou qualquer alteração mais drástica, impediria que essas manifestações artísticas perpetuadas fossem estudadas e conhecidas pelas próximas gerações, a dos arqueólogos. Esse enunciado dialoga com o outro, datado de junho de 1987, já destacado: "Gostaríamos de incutir em todos os nossos cidadãos um sentimento de orgulho e carinho para nos permitir mostrar as pinturas e as gravuras para os nossos netos e bisnetos." Trata-se de associar os sentimentos de pertencimento dos cidadãos a uma antiguidade sulafricana ao bom comportamento, o qual possibilite a transmissão dos bens culturais relativos a esse passado para o seleto grupo de cidadãos que saibam apreciar a arte rupestre com a postura apontada como correta pelos editores.

priorities, that may lead to serious clashes. The authorities' approach to a particular area is to impose control over the management of the sites and the people, in order to prevent what they see as vandalism. Indigenous people and Bantu speaking people relate to the sites differently, because they consider them to be significant. The priority of heritage management according to the Western approach is to keep things as they are, without making any changes that are going to alter them. The main priority is therefore to preserve items and places as original artworks to be admired by all. According to the African approach, management would not just be interested in keeping the rock art as an original artwork to be admired (as in the case of the Sitholes, see Prins 1997), but in the spiritual management of the site as well. According to the proponents of this management practice, people should feel the spiritual power when visiting a particular rock art site considered sacred to them, and for this to happen, ritual activities need to take place and, in some cases, offerings need to be made. These activities, in some instances, can be 'harmful' to the paintings themselves, but unlike the Western understanding of rock art management, the focus would be more on spiritual management. (NDLOVU, 2005, p.20)

60 Self-centred people are removing engravings from their sites of origin thereby destroying the archaeological and artistic associations forever. (TSAAB, dez. 1987, vol.42, n.146, p. 86) 
Ser cidadão é ter direitos - entre eles os culturais e políticos - situação esta estranha à maioria da população negra e mestiça durante o regime segregacionista da África do Sul no período abrangido pelo nosso recorte temporal.

A função social de educar os leigos em relação ao patrimônio arqueológico é uma das metas SAAS, que publica a TSAAB, ao longo do nosso recorte temporal. Percebe-se, pelo teor dos editoriais do corpus, um elevado grau de tensão quando a editora principal e os editores convidados definem como os habitantes, os turistas e os profissionais deveriam interagir com o patrimônio arqueólogico. Em dois editoriais, Janette Deacon recomenda o expediente de chamar a polícia para os "vândalos". Estes são os sujeitos que não possuem o comportamento adequado avaliado pela editora. (TSAAB, dez. 1987, vol.42, n.146, p. 86; TSAAB, junho 1991, vol.46, n.154, p.59).

Um tema recorrente nos editoriais é o tráfico ilícito de objetos retirados das escavações e de acervos constituídos. A gestão patrimonial passa pela identificação dos vestígios arqueológicos como pertencentes à memória das populações pretéritas e/ou nativas. O incentivo ao tráfico de objetos arqueológicos e o valor das peças para quem as trafica são assuntos pertinentes à depreciação econômica dos Estados da África nas décadas de 1980 e 1990 e à progressiva dissociação de significado dos artefatos históricos e arqueológicos das identidades dos povos africanos (SCHMIDT e MCINTOSH, 1996).

Os acordos com o Fundo Monetário Internacional (FMI) e o Banco Mundial (BM) levaram os países da África Central e Austral ao Plano de Ajustamento Estrutural que penalizou a população. Posteriormente, os empréstimos do FMI e do BM foram atrelados a uma política de Gestão do Patrimônio Arqueológico, devido ao abandono dos sítios arqueológicos e históricos e do tráfico internacional de objetos arqueológicos, históricos e de arte, situação essa relatada por arqueólogos africanos e africanistas. Em editorial da TSAAB, de junho de 1991, J. Deacon denuncia:

Nós primeiro fomos alertados em julho de 1990, quando nos foi mostrado um catálogo distribuído pelo Sr. Gregory Marcinek do Texas, que estava vendendo uma série de itens do [sítio histórico do] 
campo de batalha Kabula em Natal, um monumento nacional declarado. Ele atestou sua autenticidade, descrevendo como ele mesmo os havia escavado no campo de batalha. (TSAAB, jun. 1991, vol.46, n.153, p.1- tradução livre $)^{61}$

Deacon destaca a existência de um mercado ilícito internacional organizado de objetos históricos sul-africanos retirados do contexto arqueológico. Sua rede estende-se pela África do Sul, passa pelos Estados Unidos e alcança a Inglaterra, conforme o prosseguimento do relato do editorial.

Cabe ressaltar que, nesse ponto, os assuntos recorrentes nos editoriais selecionados foram a gestão do patrimônio arqueológico e o papel da comunidade nativa nesse empreendimento. As primeiras legislações sobre patrimônio cultural apareceram, entre outros lugares, na Austrália. Nesse país, até o final da década de 1960, o governo ditava quais bens culturais aborígenes seriam protegidos e de que modo. Nas décadas de 1970 e 1980 houve a mudança dessa mentalidade com a promulgação das legislações que reverberaram internacionalmente na arqueologia: Aboriginal Heritage Act (1972); Aboriginal Heritage Act, número 12 (1988); e, Northern Territory Governments and Commonwealth's Aboriginal and Torres Strait Islander Heritage Protection Act (1984) (NDLOVU, 2005, p.68-9).

Segundo Nègri (2009, p.5) e Rakotomamonjy (2009, p.5), atualmente, o patrimônio cultural é protegido por leis nos respectivos países centro e sulafricanos:

- Malawi: Monuments Act (1965);

- Lesotho: The Historical Monuments, Relics, Fauna and Flora Act (1967);

- Suazilândia: The National Trust Commission Act (1972);

- Zimbábue: National Museums and Monuments of Zimbabwe Act (1972);

- Zâmbia: National Heritage Conservation Commission Act (1989);

\footnotetext{
${ }^{61}$ We are first alerted in July 1990 when we were shown a catalogue distributed by Mr. Gregory Marcinek of Texas who was offering for sale a number of items from the Kabula battlefield in Natal, a declared national monument. He vouched for their authenticity by describing how he had excavated them from the battlefield himself. (TSAAB, jun. 1991, vol.46, n.153, p.1)
} 
- África do Sul: National Heritage Resources Act (1999);

- Gabão: Constitution du Gabon, artigo 47 - La protection du patrimoine artistique, culturel et archéologique, revisado em 2003.

- Organização da Unidade Africana (OUA): Carta Cultural Africana (1976).

Observa-se que essa proteção foi consolidada nas décadas de formação dos Estados nacionais da África Central e Austral e com o fim do apartheid na África do Sul e se deu graças aos interesses sociais, políticos - relativos à identidade nacional - e econômicos - relativos ao turismo - sobre os vestígios do pretérito e sobre a identificação e reserva dos lugares significativos das comunidades nativas naquele momento.

Segundo Meneses (2003), os bens culturais preservados dão subsídios à identidade cultural que é um processo contínuo de construção, aqui considerado para a nossa discussão. A imagem do arqueólogo sul-africano veiculado pelos editoriais associa-se à responsabilidade de zelar por eles. Essa formulação tem no âmago duas ações: escolher o que será protegido e afastar as pessoas ou comunidades, as quais não partilham das mesmas ideias sobre a proteção do patrimônio arqueológico. Ainda para Meneses (2003):

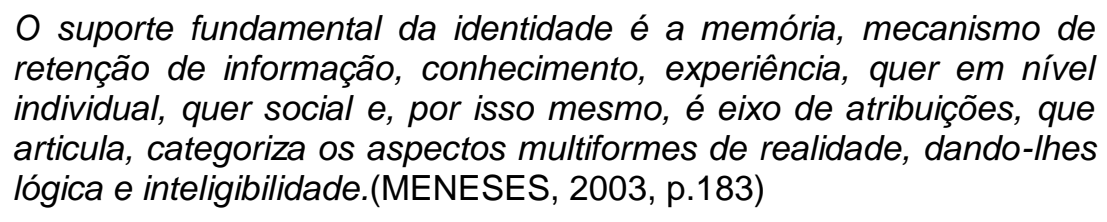

A memória seletiva e induzida, enquanto mecanismo de retenção do conhecimento e da experiência, é alimentada pela interação e atribuição de sentido aos objetos e sítios arqueológicos por parte dos arqueólogos e das comunidades locais.

Em relação à profissão dos arqueólogos, constatamos que preservação do patrimônio é essencial para o conhecimento do passado pelos estudiosos atuais e futuros e pela comunidade nacional e local. Daí, observamos o teor da abordagem sobre as temáticas: preservação do patrimônio arqueológico, relações de poder e memória. Até o momento, em relação à bibliografia, 
verificamos questionamentos diferentes oriundos de pesquisadores ocidentais e africanos. Entre eles:

i) De que maneira será feita a gestão patrimonial nos países africanos? e,

ii) $O$ protagonismo cabe às instituições internacionais, às instituições nacionais ou às comunidades locais?

A gestão patrimonial é foco de alguns editoriais. O posicionamento dos editores da TSAAB quanto aos procedimentos das instituições nacionais e a necessidade de recorrer a organismos e estatutos internacionais para garantir a preservação do patrimônio arqueológico e da memória podem ser explicados. De um lado, pela urgência de uma rápida e vigorosa intervenção, dado o distanciamento dos arqueólogos das comunidades. E, por outro, pela pouca referência ao papel das comunidades locais na preservação do patrimônio arqueológico, a qual pode ser justificada pelas identidades locais instrumentalizadas para a construção da identidade nacional.

Supostamente, se os leitores do editorial fossem apenas arqueólogos profissionais, esses tipos de enunciados poderiam não aparecer em um boletim arqueológico. Porém, veremos que, em outro editorial, escrito pelo arqueólogo convidado Jannie Loubser e datado de dezembro de 1990, aparece um daqueles trechos relacionado ao enunciado escrito por Janette Deacon acima reproduzido - "Não molhe ou toque pinturas rupestres, e nunca tente tocar ou rabiscar sobre gravuras rupestres":

\begin{abstract}
Alguns [conservadores de museus] até chegaram ao ponto de chamar os arqueólogos de 'vândalos' e 'imperialistas culturais'. [...] Por exemplo, quantos de nós pode dizer honestamente que nunca tocou ou molhou pinturas rupestres? No decorrer do nosso trabalho, somos muitos, por certo, que não estamos cientes dos possíveis danos causados pela superlotação dos sítios, pela peneiração, pelo registro, pelo pó, pelo embalamento, pela limpeza e pelo armazenamento - para mencionar alguns exemplos. (TSAAB, dez. 1990 , vol.45, n.152, p. 71 - tradução livre, grifos nossos) ${ }^{62}$
\end{abstract}

\footnotetext{
${ }^{62}$ Some even went so far as to call archaeologists 'vandals' and 'cultural imperialists'. [...] For example, how many of us can honestly say that never touched or wet rock paintings? In the course our work we also take a lot for granted, we are not always aware of possible damage caused by overcrowding sites, sieving, recording, dust, packing, cleaning and storing - to mention a few examples. (TSAAB, dez. 1990, vol.45, n.152, p. 71)
} 
No início da década de 1990, um editorial da TSAAB nesse teor seria um indicativo da difusão, por parte de uma corrente da SAAS, de uma concepção aparentemente pós-processualista da insustentabilidade do trabalho de campo destrutivo do arqueólogo, ou seja, de uma crítica ao profissional que "extrai" de modo despreocupado os artefatos dos sítios, não considerando a qualidade da interação dos especialistas com os habitantes locais que poderiam, no futuro, impedir que os arqueólogos entrassem nesses sítios significativos (TILLEY, 1989).

Dando continuidade a nossa reflexão sobre a crescente conscientização dos arqueólogos quanto às suas responsabilidades sociais, Aron Mazel, editor convidado em dezembro de 1991, escreve:

[Os] arqueólogos sul-africanos são agora muito mais receptivos a tomar consciência de suas responsabilidades para com a sociedade do que eram como um todo há uma década. [...] [Mas] nem todos os arqueólogos consideram-se educadores públicos, e nem todos se considerarão no futuro. No entanto, se nós não publicamos nossas pesquisas, então aqueles que o fazem não estão em condições de comunicá-las ao público. (TSAAB, dez. 1991, vol.46, n.154, p.59 tradução livre, grifos nossos) ${ }^{63}$

Nota-se que nesses editoriais são veiculadas algumas das facetas da imagem ideal do arqueólogo sul-africano, segundo o estatuto da SAAS e do TSAAB: a do educador. A instrução ao público, objetivo identificado no lançamento da SAAS e do boletim em 1945, segundo o editor convidado, seria uma função pouco desenvolvida pelo grupo de especialistas sul-africanos. Acrescente-se a essa situação, segundo Mazel, a falta de divulgação das pesquisas e das novas explicações sobre o pretérito da África do Sul e da África Austral como um todo, realizadas pelos arqueólogos qualificados, os quais são profissionais treinados e membros das sociedades arqueológicas.

O papel de educador é uma das questões do boletim TSAAB ao construir a imagem do "arqueólogo sul-africano", que no final da década de 1980 e início da década de 1990, aparece aparentemente como socialmente

\footnotetext{
${ }^{63}$ South African archaeologists are now considerably more conscious of, and receptive to, their responsibilities to society as a whole than they were a decade ago. [...] Not all archaeologists consider themselves public educators, and not all will in the future. However, if we do not publish our research findings, then those who do will not be in a position to communicate them to the public. (TSAAB, dez. 1991, vol.46, n.154, p.59)
} 
engajado e aparentemente influenciado pela corrente pós-processualista, no crepúsculo do regime segregacionista da África do Sul.

A preocupação com a preservação patrimonial e a sua legislação apresenta-se nos editoriais subsequentes escritos por Janette Deacon, editora principal, e pelos editores convidados Hilary John Deacon, Martin Hall, os já citados Jannie Loubser e Aron Mazel.

Em junho de 1988, Hilary John Deacon escreveu sobre o projeto da nova legislação Environment Conservation Act, aprovada somente em 1989, na África do Sul:

Estamos todos muito conscientes da pilhagem de inúmeros sítios costeiros, devido o substancial desenvolvimento dos resorts e da destruição dos sítios históricos através da reconstrução deplorável. [...] Os serviços dos gestores de recursos culturais arqueologicamente treinados vão ser necessários para avaliar os impactos, iniciar as pesquisas, realizar as escavações de salvamento e para implementação de programas de conservação e educação. (TSAAB, junho de 1988, vol.43, n.147, p. 3 - tradução livre, grifos nossos) ${ }^{64}$

Instruir os leigos em preservação patrimonial é uma das funções sociais da SAAS veiculada pelo TSAAB. A imagem ideal do arqueólogo sul-africano, difundida nos dois trechos dos editoriais acima, é a do profissional treinado, responsável socialmente pelos programas de conservação e educação, que deve se preocupar com a destruição do patrimônio arqueológico proporcionada por um tipo de desenvolvimento econômico a qualquer custo.

Nos editoriais da TSAAB, a gestão do patrimônio arqueológico africano é considerada precária, necessitando de intervenções no processo destrutivo realizado por nacionais ou estrangeiros e de uma regulamentação precisa quanto ao contato com o material arqueológico. A ideia de desenvolvimento perpassa a reflexão sobre a proteção jurídica do patrimônio cultural. Segundo esse editorial transcrito acima, o desenvolvimento econômico - vinculado ao turismo - impacta a proteção do patrimônio arqueológico do seu país. Se há

\footnotetext{
${ }^{64} \mathrm{We}$ are all too aware of the despoilation of countless coastal sites through the stringer development of resorts, and the desecration of historic sites through poor reconstruction. [...] The services of archaeologically trained cultural resources managers are going to be necessary to assess impacts, initiate surveys, carry out recovery excavation and implement conservation and education programs. (TSAAB, junho de 1988, vol.43, n.147, p. 3)
} 
necessidade de implantar obras de infraestrutura para consolidar os avanços econômicos, sociais e políticos do país, a arqueologia de salvamento concorre para minimizar os impactos da destruição da paisagem cultural ali constituída.

O desenvolvimento econômico pautado na cooperação entre Estado nacional com as comunidades locais seria a possibilidade de preservar sua memória, atendendo às demandas comunitárias pela afirmação da identidade local em harmonia com a estrutura nacional. Fazem-se necessários alguns ajustes para que a gestão do patrimônio arqueológico, as relações de poder e a memória dos principais interessados, as comunidades, as quais continuam a interagir com os sítios arqueológicos e os objetos dali retirados, possam estabelecer um ponto de equilíbrio após os conflitos civis agudos das décadas de 1980 e 1990.

Martin Hall, editor convidado em dezembro de 1989, considerando essa nova legislação que abre a possibilidade de estabelecer a Arqueologia de Contrato na África do Sul, escreve:

\begin{abstract}
Parece-me que a questão central é o controle: o controle sobre o credenciamento e o controle sobre a prática [arqueológica]. [P]recisamos de um corpo profissional forte [...] Esse organismo teria que credenciar profissionais e supervisionar os padrões profissionais. Porém, como esse corpo profissional claramente não pode ser coincidente nem com a South African Archaeological Society ou nem com a Southern African Association of Archaeologists, as quais têm que servir mais amplamente os interesses [hegemônicos], e por vezes contrariamente, do que a Arqueologia de Contrato. Assim, um novo instituto profissional terá de ser formado. (TSAAB, dez. 1989, vol. 44 , n.150, p. 63-4 - tradução livre, grifo do autor $)^{65}$
\end{abstract}

Afinal, quais são esses padrões profissionais requisitados nos editoriais da TSAAB e que, na nossa interpretação, formam a imagem do arqueólogo ideal difundido pelos documentos do corpus?

Para respondermos a essa questão, retomemos alguns desses enunciados destacados nos trechos dos editoriais que foram transcritos:

\footnotetext{
${ }^{65}$ It would seem to me that the central issue is control: control over accreditation and control over practice. $[\ldots][\mathrm{W}] \mathrm{e}$ need a strong professional body [...] Such a body would accredit practitioners and oversee professional standards. But such a professional body clearly cannot be coincident with either the South African Archaeological Society or the Southern African Association of Archaeologists, both of which have to server wider, and sometimes contrary, interests than Contract Archaeology. Thus a new professional institute will have to be formed. (TSAAB, dez. 1989, vol. 44, n.150, p. 63-4)
} 


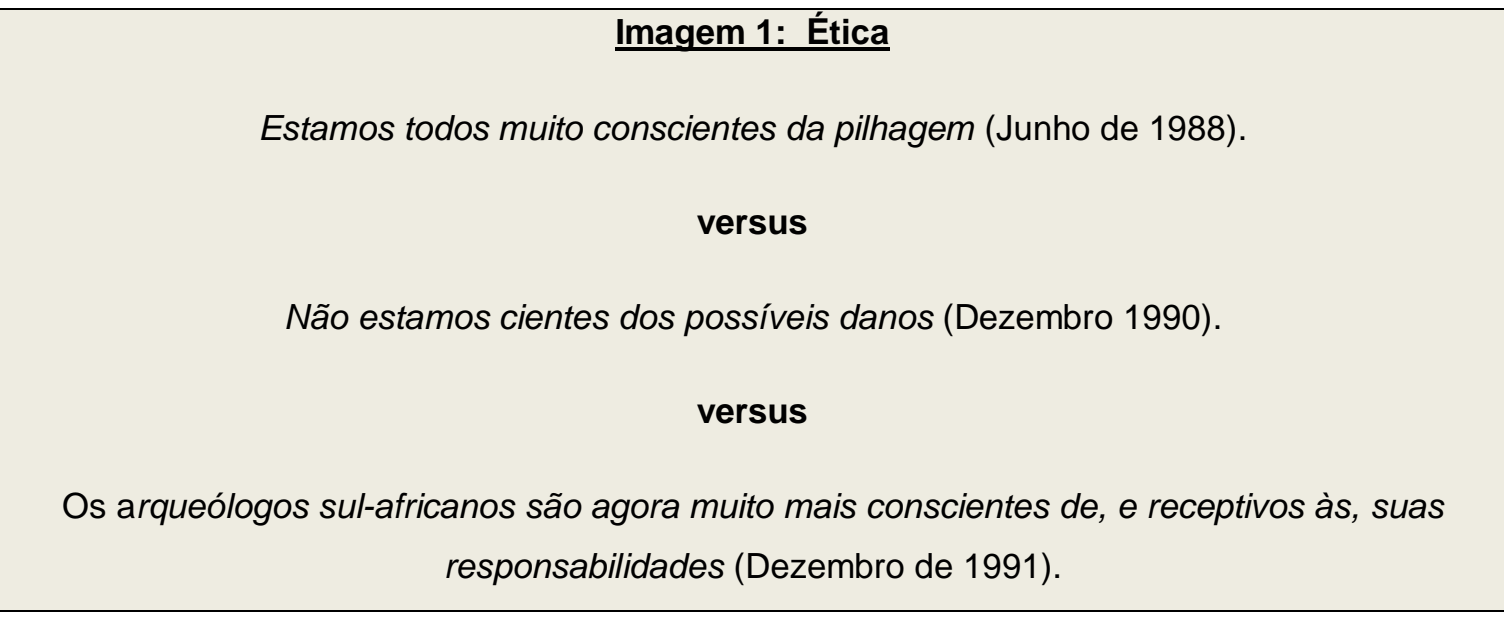

A SAAS, por meio de seu boletim TSAAB, vê-se com a missão de informar a população inconsciente sobre os riscos que o patrimônio arqueológico corre. Entretanto, nos anos de 1987 e 1993, essa missão veiculada pelos editoriais, tomou outro direcionamento: propiciar aos arqueólogos sul-africanos textos críticos sobre sua ética no trabalho durante os anos finais do regime segregacionista, de difusão das ideias da corrente pósprocessualista e dos estudos pós-coloniais. Nesse sentido, a primeira construção da imagem dos arqueólogos veiculada pelos boletins refere-se à Ética (ver quadro acima sobre a imagem um).

No primeiro enunciado "estamos todos muito conscientes da pilhagem", observamos a tentativa de apresentar o arqueólogo sul-africano engajado na proteção do patrimônio arqueológico e sabedor das atitudes depredatórias da população nos sítios. Em contraposição, no segundo, "não estamos cientes dos possíveis danos", denota a dificuldade dos profissionais em serem autocríticos em relação às suas próprias atitudes depredatórias nos sítios arqueológicos. Por fim, no terceiro, em mais outra contraposição, é subentendido a ideia de consciência para a sua responsabilidade social. Desse modo, os três enunciados, assim considerados, formam uma imagem ética caleidoscópica, na qual o arqueólogo sul-africano ideal é consciente das atitudes depredatórias da população, é consciente das suas próprias atitudes depredatórias e têm percepção da sua responsabilidade social. 
Gestores de recursos culturais arqueologicamente treinados vão ser necessários (Junho 1988).

O controle sobre o credenciamento e o controle sobre a prática (Dezembro 1989).

A imagem dois relaciona-se à função regulatória da sociedade científica. A legitimidade de quem pratica arqueologia dá-se pelo fortalecimento do corpo profissional enquanto organismo que desempenha uma função importante na sociedade: possibilitar a transmissão do conhecimento científico sobre o passado dos povos da África Austral. A situação da arqueologia da África do Sul, até 1994, segundo Bagodo (2004, p.448) caracterizava-se pela minoria branca deter o direito da formação e informação institucionalizada na disciplina. Era necessário definir os meios de acesso a essa legitimidade através do treinamento, como ordena o primeiro enunciado - "gestores de recursos culturais arqueologicamente treinados vão ser necessários" - e do credenciamento dos arqueólogos nas sociedades reguladoras da prática do especialista, como manda o segundo enunciado - "o controle sobre 0 credenciamento e o controle sobre a prática".

\section{Imagem 3: Relação com a sociedade}

Gostaríamos de incutir em todos os nossos cidadãos um sentimento de orgulho e carinho (Junho de 1987).

\section{versus}

Nem todos os arqueólogos consideram-se educadores públicos (Dezembro de 1991).

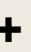

Se não publicamos nossas pesquisas (dezembro de 1991).

A SAAS enquanto instituição possui, aparentemente, um limite de atuação na esfera da profissionalização do arqueólogo que mira o nicho da Arqueologia de Contrato. Para não perder o controle sobre a prática do arqueólogo de contrato ou mesmo sobre os aqueles que não são legitimados a exercer a profissão, lança mão, através dos editoriais da TSAAB, dos aspectos 
éticos e acadêmicos da disciplinização da prática arqueológica: a educação do público, a publicação dos resultados, a aceitação dos pares e dos membros da sociedade científica sob perigo da destruição do patrimônio.

O primeiro enunciado da imagem três, "Gostaríamos de incutir em todos os nossos cidadãos um sentimento de orgulho e carinho", é um fragmento do tipo de instrução ao leitor que a SAAS veicula. Na perspectiva da editora principal do TSAAB, Janette Deacon, os cidadãos desse enunciado, que deveriam ter o sentimento de orgulho e carinho com relação ao patrimônio incultido em suas mentes, através da educação patrimonial, são algumas populações nativas - vide citação anteriomente feita do editorial de dezembro de 1987. Por sua vez, essa interação dos arqueólogos com a sociedade é pouco efetiva. Em primeiro lugar, considera-se que as populações precisam aprender a lidar com o patrimônio arqueológico com os especialistas. Em segundo, estes, na realidade, não estão interessados na educação patrimonial. $\mathrm{E}$, em terceiro, os profissionais também não difundiam as suas pesquisas para a sociedade sul-africana.

Dessa forma, nos editoriais, é veiculada a ideia de que a consciência da destruição/proteção do patrimônio arqueológico atrela-se à função social do arqueólogo como educador. Esses enunciados formam as imagens do que é ser arqueólogo africano e africanista na África do Sul. Constatamos que há uma tensão na construção das imagens de ética, prática arqueológica e relação com a sociedade. Essa tensão possivelmente se deve à tentativa da SAAS de estabelecer entre os arqueólogos da sociedade uma ética, uma prática e uma relação com a sociedade que não são amplamente aceitas pela comunidade arqueológica sul-africana.

O exame dos enunciados dos editoriais do TSAAB do período compreendido entre os anos de 1987 e de 1993 aponta para uma preocupação recorrente da SAAS quanto à profissionalização da disciplina.

Desde a Segunda Guerra Mundial, os arqueólogos africanistas e africanos, apoiados no fomento de outras disciplinas como a Física, a Química, dos Estudos Ambientais e na afirmação da Arqueologia como ciência de especialistas, consolidaram as sociedades de arqueologia através da adesão 
dos sócios, da publicação nos seus boletins e da participação nas suas reuniões. Um retorno aos primeiros editoriais do TSAAB indica outra estratégia para a consolidação da SAAS: o apoio político e financeiro dos arqueólogos amadores e dos leigos interessados nas descobertas relativas à antiguidade humana no continente africano ou, especificamente, na África Austral.

Além dos enunciados, outros elementos compõem esse jogo de ideias sobre a construção da imagem do arqueólogo. Esses elementos, essenciais, são os próprios editores. Nos próximos parágrafos trataremos dos aspectos biográficos desses editores e o modo como esses aspectos torna mais eficaz a carga imagética do que é ser arqueólogo no corpus documental do TSAAB.

Entre 1976 e 1994, Janette Deacon, arqueóloga da Stellenbosch University, assumiu a edição do boletim sul-africano TSAAB. Ela foi editora ao longo de 17 anos e meio, em um período no qual ocorreu a inserção de novas tecnologias de informática na pesquisa arqueológica e na editoração do boletim. Nessa época a arqueologia sul-africana passou por mudanças, em parte, pela adesão à corrente teórica da Nova Arqueologia e da Arqueologia Pós-Processual e, em parte, pela injeção de investimentos estrangeiros na economia capitalista "racializada" da África do Sul. Seu principal tema de pesquisa foi o povo KhoiSan localizado na África do Sul: a paisagem em que viviam, sua cultura material e, especialmente, a arte rupestre na região de Northern Cape. (THE SOUTH AFRICAN ARCHAEOLOGICAL SOCIETY c, acesso em 03/11/2012). 
Figura 6 - Janette Deacon ministrando curso para a formação de guias locais do sítio arqueológico de Mapungubwe (2006).

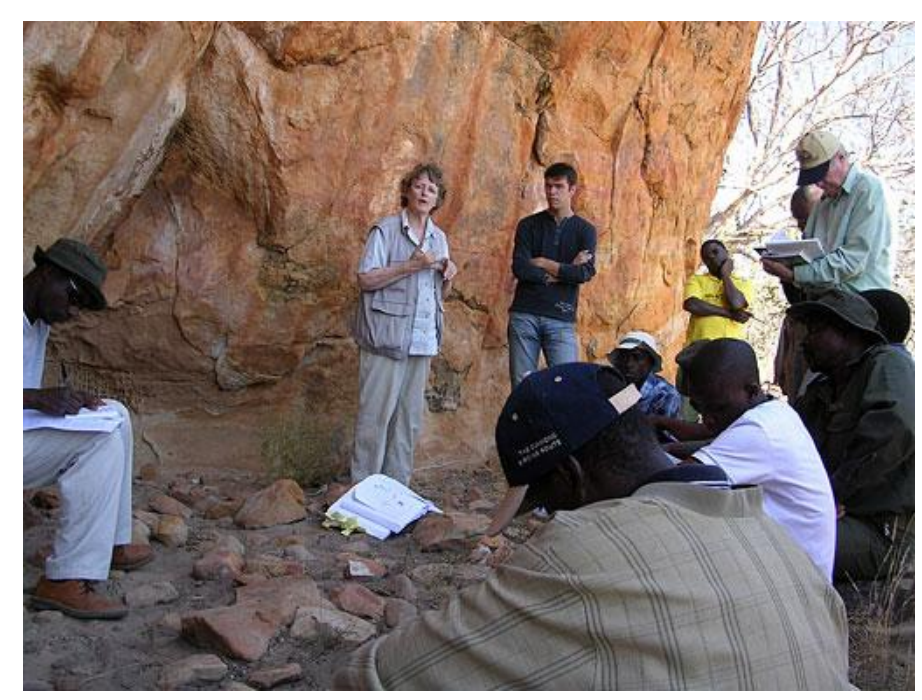

Fonte: GETTY CONSERVATION INSTITUTE. Créditos: Trinidad Rico, acesso em 04/11/2012.

A editora também tinha interesse em divulgar a arqueologia para 0 público leigo, dando continuidade à função social da SAAS. Assim, em 1978, deu início às novas publicações: Newsletter e The Digging Stick. Conforme Leslie et al. (2000, p.87), o TSAAB tinha ficado com uma linguagem muito técnica e pouco acessível aos leigos, daí o surgimento dessas novas publicações para suprir a demanda por informação desses leitores.

Deacon desenvolveu projetos de musealização de sítios visando à educação do público no geral, como ocorreu com o sítio arqueológico de hominídios Nelson Bay Cave, habitado entre cem mil anos e trezentos anos atrás (vide figura sete). A proposta era proteger os sítios que estavam desbarrancando ou sofriam de erosão. Entre as atividades de educação patrimonial estava o treinamento dos guias locais e a disseminação dos legados dos povos nativos entre as comunidades e as escolas locais (LESLIE et al., 2000). 
Figura 7 - Entrada do sítio Nelson Bay Cave, localizado em Western Cape, África do Sul, s.d.

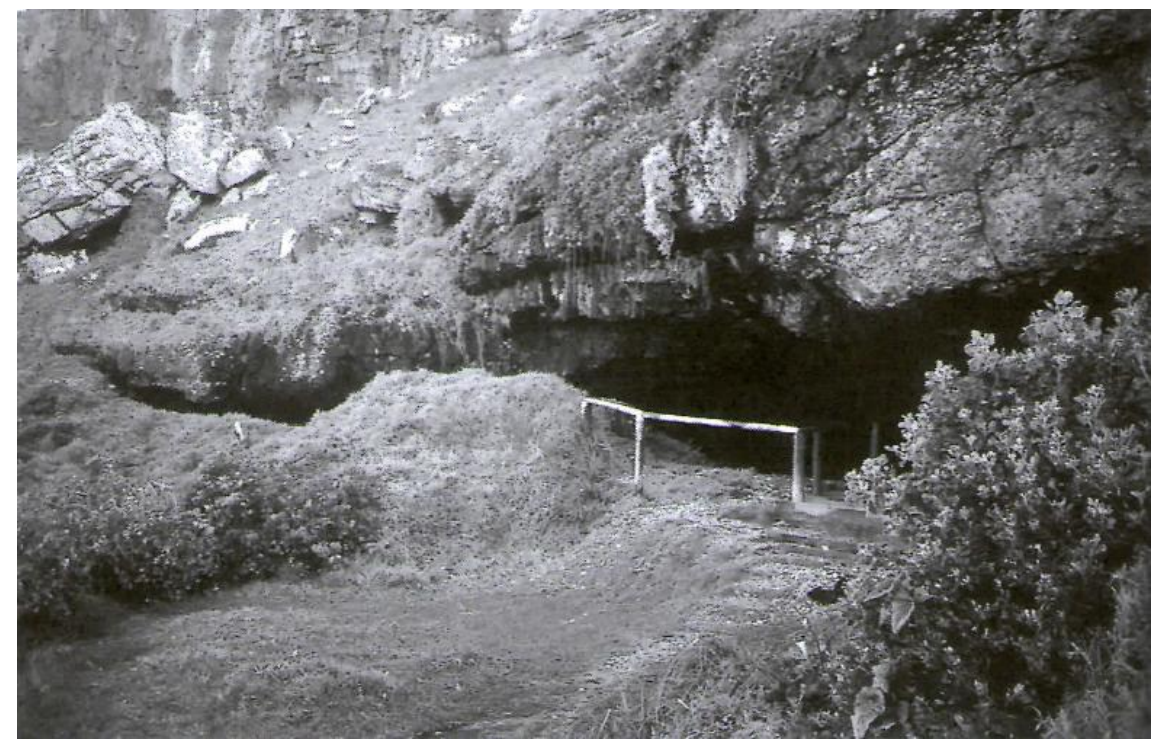

Fonte: MITCHELL, 2002, p.176.

Segundo Leslie et al. (2000), devido a sua especialização em arte rupestre, sua preocupação com a divulgação da arqueologia e com a conservação dos sítios, Janette Deacon tornou-se especialista em remover pichações dos sítios rupestres. Em 1989, trabalhou no National Monuments Council e criou um sistema de inspeção, conservação e promoção da antiga herança dos sítios arqueológicos sul-africanos. Foi um dos membros fundadores do Southern African Associaton of Archaeologists. Fez trabalhos em parceria com South African Museums Association, School of Conservation e Palaeontological Society of South Africa. Foi membro do Arts and Culture Task Group (ACTAG) e ajudou a desenvolver uma nova legislação para proteger o patrimônio arqueológico da África do Sul.

Passou a ser secretária do Southern African Rock Art Project e, a partir 1961, também foi secretária do Western Cape Branch, sucursal da SAAS. Foi presidente da SAAS entre 1994 e 1996. Em 2000, tornou-se membro do SAHRA - South African Heritage Resources Agency Council e do Western Cape Cultural Commission. Foi vice-presidente da Pan-African Association for Prehistory and Related Studies e participou da South African World Heritage Convention Committee (LESLIE et al., 2000). 
Janette Deacon produziu, entre 1987 e 1993, dez editoriais, sem títulos, os quais foram identificados por nós pelas seguintes palavras-chave principal e secundária:

\begin{tabular}{lcc}
\hline \multicolumn{1}{c}{ Editorial } & Palavra-chave principal & Palavra-chave secundária \\
\hline 1987 Junho, vol.42, n.145, p.3-4. & Gestão patrimonial & Patrimônio arqueológico \\
1987 Dezembro, vol.42, n.146, p. 86. & Gestão patrimonial & Congresso \\
1988 Junho, vol.43, n.148, p. 77. & Gestão patrimonial & Patrimônio arqueológico \\
1989 Junho, vol.44, n.149, p. 2. & Sociedade científica & Obituário \\
1990 Junho, vol.45, n.151, p.3. & Gestão patrimonial & Patrimônio arqueológico \\
1991 Junho, vol.46, n.153, p.1. & Gestão patrimonial & Roubo \\
1992 Junho, vol.47, n.155, p. 1. & Sociedade científica & Congresso \\
1992 Dezembro, vol.47, n.156, p. 73. & Gestão patrimonial & Arqueologia comunitária \\
1993 Junho, vol.48, n.157, p.1. & $\begin{array}{c}\text { Organização do boletim } \\
\text { Egtica }\end{array}$ \\
1993 Dezembro, vol.48, n.158, p.63. & $\begin{array}{c}\text { Agradecimentos e } \\
\text { homenagens }\end{array}$ & Obituário \\
\hline
\end{tabular}

A editora Janette Deacon desenvolveu muitos trabalhos em parceria com o marido, também arqueólogo, Hilary John Deacon que foi o autor do editorial datado de junho de 1988 com o título "Qual futuro tem a arqueologia na África do Sul?'66 (vol. 43, n.147, p.3). A palavra-chave principal desse editorial é "Educação" e a palavra-chave secundária é "Legislação".

O sul-africano H.J. Deacon (1936-2010), graduado em Geologia, foi chefe do Departamento de Arqueologia da Stellenbosch University. Seus professores foram Goodwin, van Riet Lowe e foi supervisionado por Inskeep. Em 1962, casou-se com Janette. Seu principal tema de pesquisa multidisciplinar era inferir a evolução comportamental humana que estava codificada no registro geo-arqueológico (SCHRIRE, 2010). Foi membro do National Monuments Council, entre 1989 e 1994, Council of the South African Museum, entre 1986 e 1998, e Iziko Museums of Cape Town, entre 1998 e 2007. Também foi nomeado presidente da South African Association of Archaeologists, da South African Society for Quartenaly Research e da South African Archaeological Society (SAAS) entre 1988 e 1990 (SCHRIRE, 2010).

\footnotetext{
66 "Guest Editorial: What future has archaeology in South Africa?"
} 
Figura 8: Hilary John Deacon, 2007.

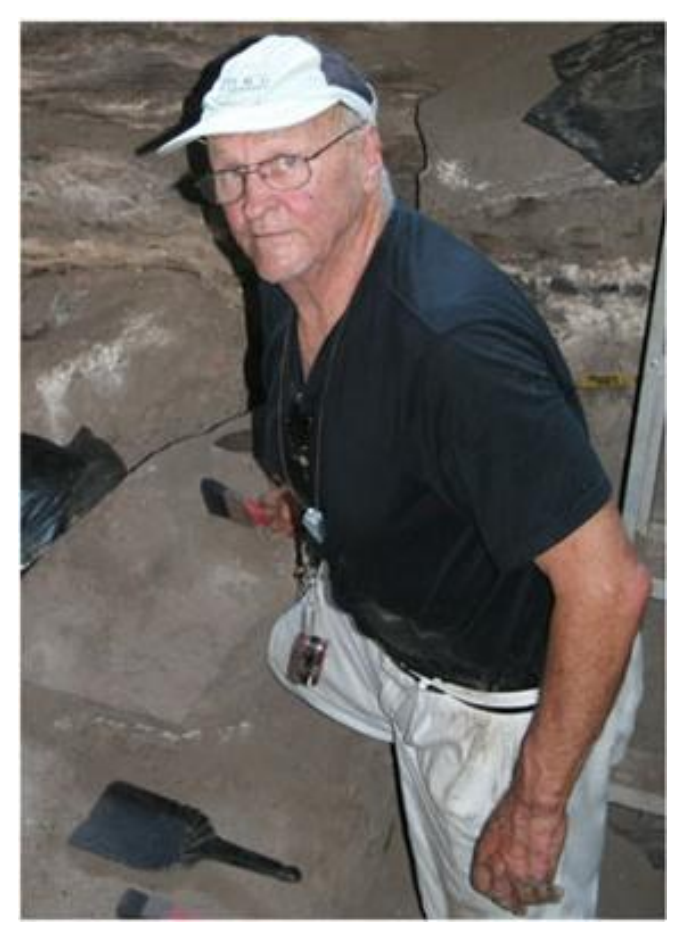

Fonte: SCHRIRE, 2010, p.02.

O britânico, com cidadania sul-africana, Martin Hall foi o editor convidado de dezembro de 1989, cujo título do editorial era "Arqueologia de Contrato na África do Sul'b7 (vol.44, n.150, p. 63). A palavra-chave principal desse editorial é "Gestão Arqueológica" e a secundária é "Legislação". Formou-se em Arqueologia e Antropologia pela Cambridge University e, em 1980, mudou-se para Cape Town. Foi chefe do Departamento de Arqueologia. Em 1983, tornouse diretor do Centre for African Studies da University of Cape Town. Em 1999, foi presidente do Word Archaeological Congress e, também, secretário geral da SAAS (UNIVERSITY OF SALFORD a, acesso em 04/11/2012).

\footnotetext{
67 "Editorial: Contract Archaeology in South Africa"
} 
Figura 9: Martin Hall, s.d.

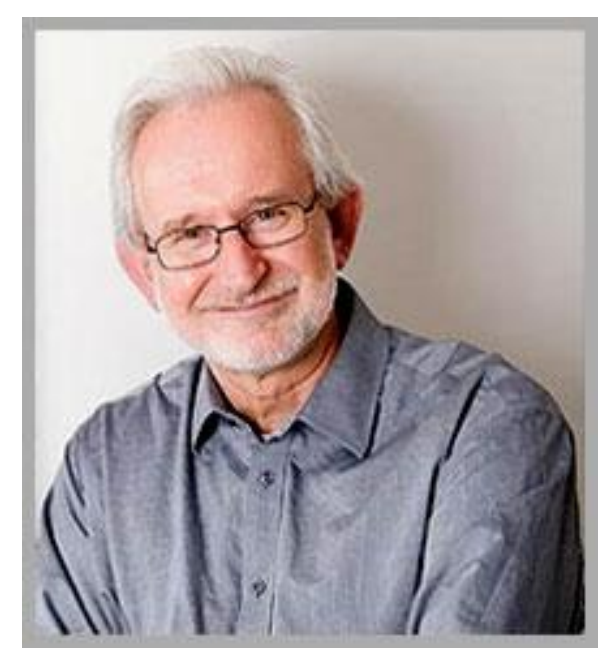

Fonte: UNIVERSITY OF SALFORD b, acesso em 04/11/2012.

O arqueólogo sul-africano e especialista em arte rupestre Johannes "Jannie" Loubser foi o editor convidado de dezembro de 1990, cujo editorial intitulava-se "Esqueletos em nossos armários: arqueólogos e conservação"68 (vol. 45, n.152, p.71). Esse tem como palavra-chave principal "Gestão Patrimonial" e como palavra-chave secundária "Patrimônio Arqueológico". Em 1989, recebeu o título de doutor pela University of Witwatersrand, na África do Sul e, desde então, trabalhou em inúmeros projetos de exploração de sítios rupestres na África do Sul, leste da África, América do Norte e do Sul, ilhas do Caribe e Austrália. Entre os anos de 1987 e 1993 foi chefe do Departamento de Arte Rupestre do National Museum of South Africa. Nessa época registrou cerca de duzentos abrigos sob rocha com arte rupestre no vale do Rio Caledon. Desenvolveu projetos na iniciativa privada na área de Gestão Patrimonial - Cultural Resource Management (CRM) - e especializou-se em remover pichações dos sítios de arte rupestre (STRATUM UNLIMITED, acesso em 04/11/2012).

\footnotetext{
68 "Guest Editorial: Skeletons in our cupboards: archaeologists and conservation"
} 
Figura 10: Jannie Loubser, s.d.

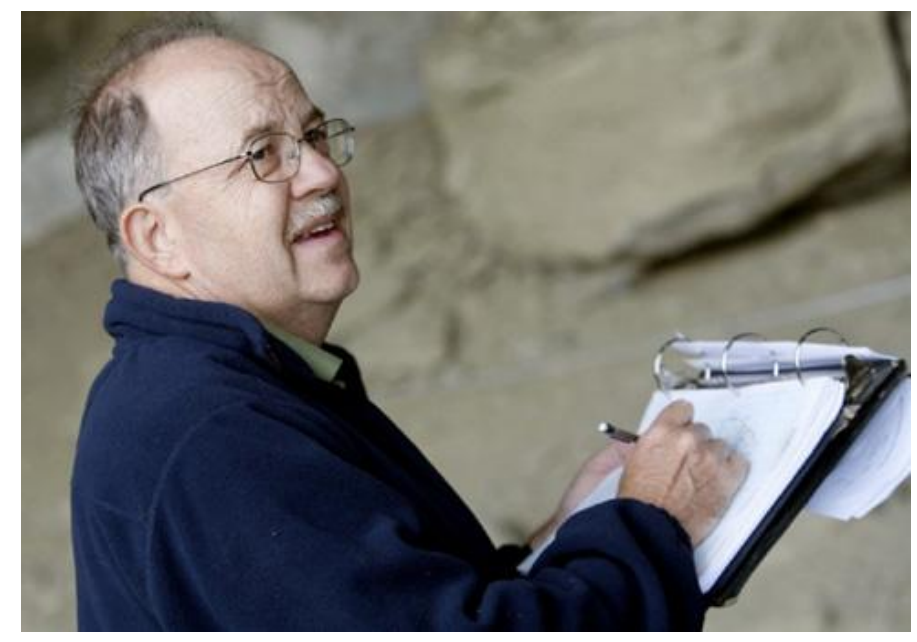

Fonte: CASEY PAGE / BILLINGS GAZETTE, acesso em 04/11/2012.

Por fim, Aron Mazel foi o editor convidado de dezembro de $1991 \mathrm{com}$ o título "Hora de expor os dados escondidos em nossos armários, arquivos, caixas etc. ${ }^{69}$ (vol.46, n.154, p.59). A palavra-chave principal do editorial é "Organização do Boletim" e a secundária é "Ética". Formou-se em arqueologia pela University of Cape Town. Atuou na gestão do Natal Museum (1981-1997), South African Cultural History Museum (1998-2002), Iziko Museums of Cape Town (2002) e na pesquisa arqueológica na África do Sul. É membro da Association of Southern African Professional Archaeologists (ASAPA), Pan African Association for Prehistory and Related Studies, South African Archaeological Society (SAAS), South African Museums Association e de várias sociedades científicas britânicas. Suas áreas de interesse são: gestão do patrimônio arqueológico e história dos museus sul-africanos (NEWCASTLE UNIVERSITY a, acesso em 04/11/2012).

\footnotetext{
69 "Guest Editorial: Time to expose the unexposed data in our cabinets, files, boxes, etc."
} 
Figura 11: Aron Mazel no centro, s.d.

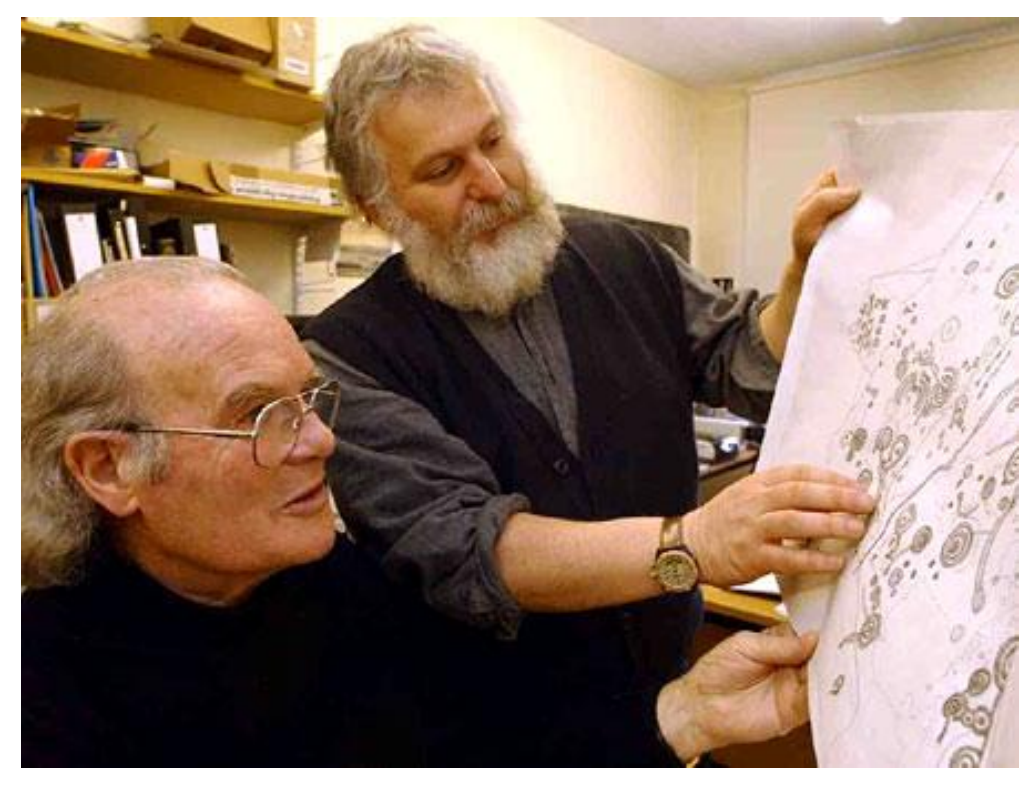

Fonte: NEWCASTLE UNIVERSITY b, acesso em 04/11/2012.

Os aspectos da vida acadêmica e da atuação dos editores foram descritos, pois, representam, nos editoriais escritos por eles, a voz da sociedade científica. Foram escolhidos entre todos os membros da SAAS, porque são os que mais têm legitimidade, segundo essa sociedade, para tratar desses assuntos por nós identificados pelas palavras-chave principal e secundária. As informações destacadas sobre suas vidas acadêmicas e profissionais trazem à tona especialistas preocupados com a gestão do patrimônio arqueológico e a educação patrimonial, justamente as imagens ideais do que é ser arqueólogo, construídas pelos enunciados selecionados para a nossa análise.

Outros elementos tornam mais eficaz à carga imagética veiculada do que é ser um arqueólogo ideal no TSAAB, como os obituários e as homenagens realizadas, "a conta gotas" ou com exclusividade. Podemos citar como exemplo o editorial de dezembro de 1993, no qual Deacon escreveu que a edição era dedicada exclusivamente a homenagear o inglês Ray Inskeep que havia se aposentado em 18 de novembro de 1993 e que teve "uma considerável influência sobre a trajetória da arqueologia da África Austral." (TSAAB, dezembro 1993, vol.48, n.158, p.63) 
Dessa forma, os editoriais do TSAAB, desse corpus documental, que abrange os anos de 1987 e 1993, tratam de celebrar alguns membros da sociedade, inclusive pelo privilégio da publicação do texto editorial, para corroborar a construção das imagens dos arqueólogos ideais sul-africanos.

\section{World Archaeological Congress - 1986}

A pressão dos países-membros da Organização das Nações Unidas (ONU) sobre o regime segregacionista na África do Sul era crescente e revelou-se em boicotes políticos, econômicos e "científicos" desde o ano de 1961. Os arqueólogos da África do Sul e da Namíbia, entre eles, Aron Mazel, editor convidado do TSAAB, foram impedidos de participar do World Archaeological Congress - daqui em diante nomeado WAC 86, realizado em setembro de 1986 em Southampton, na Inglaterra, e organizado pela International Union for Prehistoric and Protohistoric Sciences (IUPPS) (UCKO, 1987). Esse "desconvite" era um "boicote científico" proposto pela ONU e ratificado pelos países e pelas sociedades ligadas à UNESCO, como a IUPPS, contra o regime segregacionista e contra a violência do Estado de Emergência imposto pelo governo sul-africano, em 1985. Por sua vez, o modo "silencioso" dos arqueólogos sul-africanos posicionarem-se contra o regime, que está implícito nos editoriais do nosso corpus documental, foi debatido nessa ocasião.

Esse episódio foi precedido pelo incidente de 1977, no qual os arqueólogos sul-africanos foram desconvidados do Pan-African Congress of Prehistory and Quartenary Studies. Também o foram em outro momento, em 1983, ocasião da reunião da Southern African Association of Archaeologists (SA3) em Gaborone, Botsuana. No episódio de 1983, houve um desentendimento entre os arqueólogos de Moçambique e do Zimbábwe, que queriam votar uma monção de condenação ao regime segregacionista, e os delegados da África do Sul que, apesar de se oporem à política racial, não queriam envolver-se em atos de rebeldia política contra o próprio governo (SHEPHERD, 2002, p.201). 
Em 20 de julho de 1985, o governo segregacionista sul-africano decretou Estado de Emergência, gerando a detenção sem julgamento de mais de 1.200 pessoas e até meados do mês de agosto do mesmo ano pelo menos 129 pessoas foram mortas. A ONU e o African National Congress (ANC), organização política sul-africana, sendo um dos membros o preso político Nelson Mandela, proclamou os países a ratificar as sanções voluntárias contra a África do Sul e posteriormente contra a Namíbia. Os Estados Unidos e a GrãBretanha não ratificaram essas sanções (UCKO, 1987).

Rapidamente essa tensão política afetou a organização do WAC 86 para formalizar o banimento, ou o chamado "desconvite", dos arqueólogos da África do Sul e da Namíbia. Apoiaram esse boicote: as organizações locais da cidade de Southampton - Southampton City Council, que forneceria as verbas para o Congresso e Students Union of Southampton, fornecedora das acomodações; as organizações internacionais como a UNESCO e associadas, como a citada IUPPS - organizadora do evento, a Pan African Association on Prehistory and Related Studies e a Association of University Teachers (AUT); os arqueólogos da África, Ásia e Leste Europeu; e, os representantes das comunidades nativas que se inscreveram no evento (UCKO, 1987).

Por sua vez, esse "boicote científico" à África do Sul foi atacado pelos arqueólogos norte-americanos, europeus ocidentais, israelitas, os próprios sulafricanos, as publicações britânica e norte-americana, como a The Times, Science e Nature (UCKO, 1987).

Para Ucko (1987), secretário-nacional organizador do evento, a situação podia ser resumida da seguinte forma: se a África do Sul participasse, muitas delegações se retirariam do congresso e se não, outras delegações se excluiriam. De qualquer modo, o caráter internacional do WAC 86 não teria mais sentido. Por fim, no final do ano de 1985, o comitê organizador confirmou o banimento dos arqueólogos sul-africanos e namíbios. A justificativa foi à aceitação voluntária das sanções impostas pela ONU e para garantir a participação do maior número de países dos lugares denominados pelos organizadores de Terceiro e Quarto Mundos (UCKO, 1987). 
Em dezembro de 1987, a editora Janette Deacon comenta o lançamento do livro de Peter Ucko, cujo título é Academic Freedom and Apartheid: the story of the World Archaeological Congress:

Ele [Ucko] faz uma leitura atraente, mesmo que o fascínio dos sulafricanos faça fronteira com o mórbido como se lê de que forma nos tornamos vítimas de uma situação paradoxal [no original, Catch-22]. ${ }_{70}$ (TSAAB, dez.1987, v.42, n.146, p.86 - tradução livre, grifos nossos)

Para entender essa situação paradoxal e a imagem dos arqueólogos sulafricanos nesses editoriais, devemos recorrer à origem da expressão "Catch-22 situation" usada pela editora Janette Deacon ao referir-se à exclusão dos sulafricanos do WAC em 1986.

Essa expressão foi cunhada por Joseph Heller no livro "Catch-22", escrito entre os anos 1955 e 1961. Nessa novela, o escritor estadunidense relata situações paradoxais vivenciadas pelos seus personagens, soldados aviadores, durante a Segunda Guerra Mundial. A obra tornou-se uma referência aos críticos da Guerra do Vietnã (BURNS, 2006; REILLY, 1998). Os paradoxos relatados referem-se às situações nas quais qualquer escolha ou posicionamento realizado pelo sujeito trará consequências indesejadas. É a situação comumente chamada por nós, no Brasil, como um "beco sem saída".

Essa expressão pode ter sido usada por Janette Deacon para retratar o desconforto dos arqueólogos sul-africanos ao serem pressionados pela comunidade internacional de arqueologia, materializado no WAC do ano de 1986, a posicionarem-se explicitamente contrários ao regime segregacionista. Em outro editorial datado de junho de 1992, a editora volta a abordar o fato:

Questões políticas e sociais têm dificultado o livre fluxo de ideias por meio da restrição do intercâmbio de resultados de pesquisas sobre pré-história africana nas últimas décadas [...] [D]esde 1977, portadores de passaportes sul-africanos foram impedidos de assistir a essas reuniões, e foram desconvidados quase dez anos depois do World Archaeological Congress em Southampton. ${ }^{71}$ (TSAAB, jun. 1992, v. 47, n.155, p.1 - tradução livre, grifos nossos)

\footnotetext{
${ }^{70}$ It makes compelling reading, even if the fascination for South Africans borders on the morbid as one reads how we became the victims in a Catch-22 situation. (TSAAB, dez. 1987, v.42, p.146, p.86)

71 Political and social issues have hampered the free flow of ideas through restricting and the [sic] exchange of research results on African prehistory over the last several decades [...] [F]rom 1977, South
} 
Segundo Peter Ucko apud Shepherd (2002, p.201), o episódio do WAC 86 gerou uma divisão entre os arqueólogos no mundo que até hoje persiste quando se questiona a relação entre arqueologia e política, ou, entre arqueologia e apartheid. Uma das facetas dessa relação indefinida com o governo segregacionista aparece no trecho do editorial escrito por Janette Deacon, datado de junho de 1987, já citado - a tentativa de estabelecer um bom relacionamento com o poder constituído - que pode ser sintetizado no enunciado anteriormente destacado: "A política dos arqueólogos tem sido recomendar ao National Monuments Council e o Tourism Board para não revelar a localização dos sítios de arte rupestre". Ora, para fazer recomendações restritivas desse modo há de se ter bem esclarecido os caminhos para alcançar as autoridades responsáveis e qual a finalidade social dessa proteção restritiva do patrimônio arqueológico.

O tema principal discutido nos editoriais do corpus é a natureza da participação social e viabilidade do engajamento político e social dos arqueólogos africanos e africanistas. O incidente do WAC 86 explicita e potencializa esse debate. Os argumentos relativos à neutralidade da ciência arqueológica face aos processos históricos do continente africano são visíveis no trecho do editorial da TSAAB de junho de 1992, conforme indica o enunciado acima destacado: "Questões políticas e sociais têm dificultado o livre fluxo de ideias". Assim, sob a elucidação desse enunciado, daqui em diante trataremos dessa temática basilar, que transpassa os assuntos do corpus documental formado pelos editoriais do TSAAB.

Julien Benda apud Bobbio (1997, p.32), que se debruçou sobre os limites do engajamento político dos intelectuais, afirma:

[O]s intelectuais têm a missão de defender e promover os valores supremos da civilização, que são desinteressados e racionais; na medida em que subordinam suas atividades aos interesses contingentes, às paixões irracionais da política, traem a sua missão. (grifos nossos)

African passport-holders were barred from attending these meetings, and were disinvited nearly ten years later from the World Archaeological Congress in Southampton. (TSAAB, jun. 1992, v.47, n.155, p.1) 
Esse raciocínio de Benda contrapôs-se aos estudos de Antonio Gramsci sobre o inevitável envolvimento dos intelectuais com a política. Estudos esses desenvolvidos, tempos depois, por Said (2005, p.34-35):

\begin{abstract}
A política está em toda parte; não pode haver escape para os reinos da arte e do pensamento puros nem, nessa mesma linha, para o reino da objetividade desinteressada ou da teoria transcendental. [...] Isso está longe de ser uma tarefa fácil: o intelectual encontra-se sempre entre a solidão e o alinhamento. [...] Não tenho nenhuma dúvida de que o intelectual deve alinhar-se aos fracos e aos que não têm representação. (grifos nossos)
\end{abstract}

Os editoriais da TSAAB imprimem a tensão do debate entre as correntes de arqueólogos da SAAS, quando apresentam a discussão sobre o papel de educador patrimonial do arqueólogo, e dos limites do engajamento político e social desses mesmos arqueólogos sul-africanos. É o que podemos verificar no trecho da carta de Aron Mazel à editora Janette Deacon datada de dezembro de 1988 e publicada junto ao editorial, cujo conteúdo foi uma resposta às críticas de C. Garth Sampson em um artigo de revisão publicado no número anterior:

[O] que eu gostaria de fazer, é chamar a sua atenção [leitor] para o ponto que, se ele [Sampson] aprecia ou não, nenhuma pesquisa em ciências sociais, nem qualquer outra pesquisa sobre o assunto, são realizadas em um vácuo social e político. Além disso, se ele quisesse, eu poderia entregar-lhe se necessário, através destas páginas, uma lista de leitura sobre a relacão entre ideologia e pesquisa. (TSAAB, dez. 1988, vol. 43, n. 148, p.78 - tradução livre, grifos nossos) $)^{72}$

O teor do debate corresponde às divisões ideológicas entre os arqueólogos da SAAS inerentes à sua exclusão no WAC 86. E, além disso, das suas dificuldades em divulgar suas ideais, participar de congressos e eventos que corroboram para a sua produção científica e imprimem o desenvolvimento da arqueologia no país. Nessa parte, nós retomamos os editoriais que tratam do investimento em treinamento dos arqueólogos, os quais debatem os cortes nos financiamentos e o baixo nível dos docentes no ensino de arqueologia comparados aos cursos europeus. Os impedimentos sofridos pelos arqueólogos sul-africanos na participação dos congressos internacionais implicaram em isolamento e gradual desmonte da disciplina arqueológica.

\footnotetext{
${ }^{72}$ But, what I would like to do, is draw his attention to the point that, whether he likes it or not, no social science research, nor any other research for the matter, is conducted in a social and political vacuum. Furthermore, if he would like, I could supply him, through these pages if necessary, with a reading list on the relationship between ideology and research. (TSAAB, dez. 1988, vol. 43, n. 148, p.78)
} 
A neutralidade política é uma atitude comum nos editoriais do TSAAB. Em seu conjunto identificamos um posicionamento cuja finalidade era à "sobrevivência" da sociedade científica e do boletim em um momento de grandes mudanças políticas e sociais no continente e na pesquisa arqueológica. Entretanto, houve certa pressão social dos grupos intelectuais mais combativos para o posicionamento "inconformado" dos arqueólogos vinculados a essas instituições, o qual não foi suficiente para a mudança do discurso nos editoriais sobre o papel ideal dos arqueólogos na sociedade sulafricana.

Quando os arqueólogos da delegação da África do Sul foram excluídos pela organização do World Archaeological Congress de 1986, graças ao seu posicionamento passivo diante do regime segregacionista, conforme relatos nos editoriais da TSAAB - vol. 42, №146, dez. 1987, p.86 e vol. 47, oㅜ155, dez. 1992, p. 01, houve uma mobilização intelectual africana e africanista fora da África do Sul em direção ao discurso dissonante no quadro político do regime segregacionista (UCKO, 1987).

Os editoriais da TSAAB podem ser considerados como espaços no qual os membros da SAAS defenderam uma corrente do pensamento arqueológico africano apartado da vida social e política, cujas ideologias não interfeririam na Ciência. Originalmente, nos anos de fundação da sociedade científica e do boletim, justamente o que verificamos é a vinculação da ciência arqueológica com a política expansionista sul-africana. Essa trajetória foi marcada pelo encarceramento da sociedade científica dentro de si mesma, excluindo os amadores e os leigos que não se enquadravam nos critérios de pertencimento de uma instituição produtora de conhecimento. Esse descolamento da vida social e política, assentado teoricamente na corrente de pensamento da Nova Arqueologia, engendrou, nos editoriais, a construção imagética dos arqueólogos sul-africanos e africanistas. 


\section{NYAME AKUMA - DE "NEWSLETTER" A "BULLETIN"}

[...] as questões são importantes reexaminando-as na medida em que a arqueologia africana continua a aceitar as relações coloniais e muitos africanos e africanistas continuam a pensar e a agir nos paradigmas coloniais. (SCHMIDT, 1995, p.120)

\section{A Sociedade e o Boletim}

O Nyame Akuma - A Newsletter of African Archaeology (NA) surgiu em outubro de 1972 como uma publicação que circularia semestralmente nos dias primeiro de outubro e primeiro de abril. As edições relativas ao nosso recorte temporal, de 1987 a 1993, não seguiram essa periodicidade definida pelo editor Peter Lewis Shinnie, no primeiro editorial, e circulou inclusive em setembro. A partir da edição de dezembro de 1989, o boletim foi veiculado semestralmente nos meses de dezembro e de junho, permanecendo com essa regularidade até a presente data. A partir da edição de junho de 1990, o periódico foi renomeado para Nyame Akuma - Bulletin of the Society of Africanist Archaeologists. O corpus documental do NA, analisado por nós, é constituído por 13 editoriais.

Conforme McBrearty (1999), o embrião da sociedade que publicaria o Nyame Akuma começou a se desenvolver em 1970, em um encontro nas proximidades da cidade de Urbana, em Illinois, Estados Unidos, organizada por Charles M. Keller da University of Illinois, antropólogo culturalista. Nessa reunião, além de Desmond Clark - África Austral, de Glen Cole - Leste da África, de Nicholas David - Norte de Camarões, de Glynn Isaac - Quênia e de Mary Leakey- Leste da África encontravam-se outros estudiosos africanistas interessados principalmente no período Stone Age (MCBREARTY,1999). A ideia da criação de uma sociedade científica e de publicar um newsletter boletim com pequenas notas sobre as pesquisas de campo - foi oficialmente lançada na First Meeting of Africanist Archaeologists, em abril de 1971.

\footnotetext{
73 [...] the issues are worth reexamining inasmuch as African archaeology continues to accept colonial relationships and many Africans and Africanists continue to think and practice in colonial paradigms. (SCHMIDT, 1995, p.120)
} 
O primeiro número do NA foi lançado em outubro de 1972, antes do estabelecimento definitivo da sociedade científica. Seu objetivo foi divulgado no próprio editorial de lançamento, escrito por Shinnie:

\begin{abstract}
Embora o principal objetivo do Newsletter seja manter o contato entre aqueles que estão na América do Norte, eu não pretendo que a [publicação] seja exclusiva e [ela] será distribuída para qualquer um que esteja trabalhando com arqueologia africana e que deseja recebê-la. Ele também transmitirá as notícias sobre as atividades escritas por aqueles que estão em outras partes do mundo além da América do Norte. (NA, outubro 1972, n.1, p.1 - tradução livre, grifos nossos $)^{74}$
\end{abstract}

No ano seguinte, na edição de número três, Isaac et al. (1973) escreveu que, entre os dias 14 e 16 de abril de 1973, ocorreu a Second Meeting of Africanist Archaeologists, na cidade de Dallas, onde foi decidido sobre a criação de uma sociedade a respeito dos estudos do homem e do seu passado na África. Essa sociedade realizaria reuniões bienais "informais" como as de Urbana e Dallas e faria a publicação de um newsletter, considerado útil e importante. Nas palavras de Isaac et al. (1973):

O foco de interesse da associacão é o estudo do passado do homem
na África, mas o seu âmbito de cobertura deve ser deixado
suficientemente elástico, de modo a abranger, quando apropriado, os
especialistas envolvidos no estudo das áreas adjacentes e / ou outras
pesquisas interligadas. Tendo em vista as aparentes intenções da
reunião - a associação quer evitar se tornar uma instituicão altamente
formalizada - nenhuma tentativa foi feita para elaborar uma
constituição legal. (ISAAC et al.,1973, p.02 - tradução livre, grifos
nossos)

Essa pretensa informalidade é notada inclusive na escolha do nome da sociedade. Nessa publicação, de outubro de 1973, sugeriu-se os nomes para votação: Association for the Study of Man in Africa (ASMA), Association for the Study of Man's Past in Africa (ASMPA), Association for the Study of Africa's Past (ASAP), Society of Africanist Archaeologists in America (SAAAm) e

\footnotetext{
${ }^{74}$ Although the main aim of the newsletter is to maintain contact between those based in North America I do not intend that it should be exclusive and it will be distributed to any one working in African archaeology who desires to receive it. It will also carry news about activities by those based in other parts of the world than North America. (NA, n.1, out. 1972, p. 1)

${ }^{75}$ The focus of interest of the association is to be the study of man's past in Africa, but the scope of its coverage should be left sufficiently elastic so as to encompass, when appropriate, scholars engaged in the study of adjacent areas and/or other interconnecting research. In view of the apparent intentions of the meeting that the association avoid becoming a highly formalized institution, no attempt has been made to draw up an elaborate legal constitution. (ISAAC et al., 1973, p.02)
} 
Association for the Study of Pre and Protohistoric Africa (ASPPA). Após a votação, adotou-se o nome Society of Africanist Archaeologists in America (SAAAm). Sua abreviatura aparece de duas formas nos editoriais do NA: SAAAm e SAAAM. Nós tomamos a grafia que aparece no texto original ao transcrevermos os trechos dos editoriais do boletim.

Ainda segundo Isaac et al. (1973, p.03), a principal meta da sociedade arqueológica africanista recém criada era "facilitar a comunicação entre os arqueólogos sediados na América do Norte" interessados em "pré-história" da África. Notamos que seu objetivo é semelhante ao do boletim NA, lançado um ano antes da sua consolidação. Essa precedência pode ser explicada pela urgência da comunicação dos arqueólogos africanistas na América do Norte e pela mobilização de Shinnie naquele momento, que pretendia inserir os especialistas africanos nesse circuito de informações promovido pela publicação norte-americana.

O objetivo da sociedade, na perspectiva do editor Shinnie, seria atingido com a realização das reuniões bienais dos membros e com a publicação de um newsletter com notícias sobre as pesquisas arqueológicas e de suas disciplinas ou temas afins, como, por exemplo, os estudos dos períodos Paleolítico e Quaternário, das tecnologias e dos comércios.

Em abril de 1988, durante a reunião da sociedade no Arizona, decidiu-se que a SAAAm passaria a ser denominada Society of Africanist Archaeologists (SAfA). A nova abreviatura da sociedade aparece grafada de duas formas nos editoriais: SAfA e SAFA. Consideramos a grafia que aparece no texto original ao transcrevermos os trechos dos editoriais do boletim. 
Figura 12 - Trecho do primeiro editorial do NA, outubro de 1972.

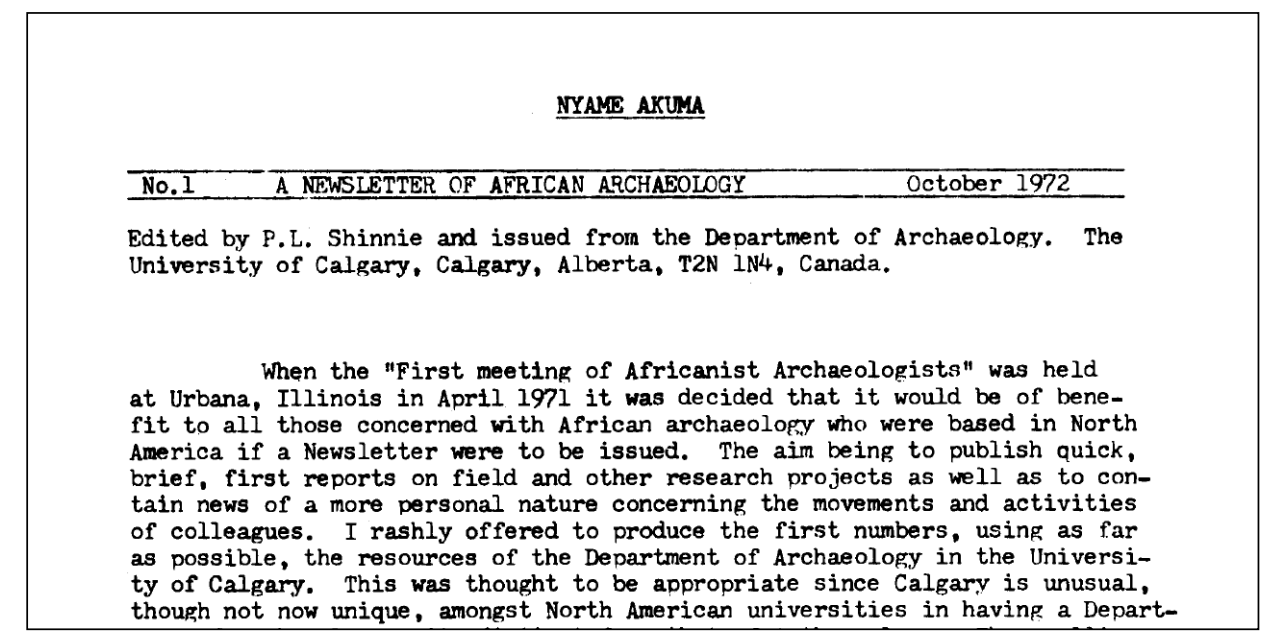

Fonte: SOCIETY OF AFRICANIST ARCHAEOLOGISTS a, acesso em 13/11/2012.

Shinnie, no primeiro editorial do NA, apresenta uma explicação para o título do newsletter. Nyame Akuma deriva do nome de um artefato conhecido pelos arqueólogos estudiosos do passado da África Ocidental que é a denominação de um machado de pedra polida, o qual foi traduzido da língua Twi - dos povos Akan ou Ashanti - de Gana, como "Machado de Deus" ou “God-Axe”. Balfour (1929) aponta que esse artefato encontrado pelos agricultores é muito utilizado como medicamento, depois de raspado e moído, pela crença nas suas propriedades curativas e protetoras. É tido pelos nativos como um vestígio de um raio lançado pelo ente sobrenatural. Assim, também encontramos a denominação "thunderbolt" para o artefato que pode ser um enxó relacionado a implementos da Idade do Ferro. 
Figura 13 - Duas ilustrações dos artefatos chamados Nyame Akuma God-Axe.

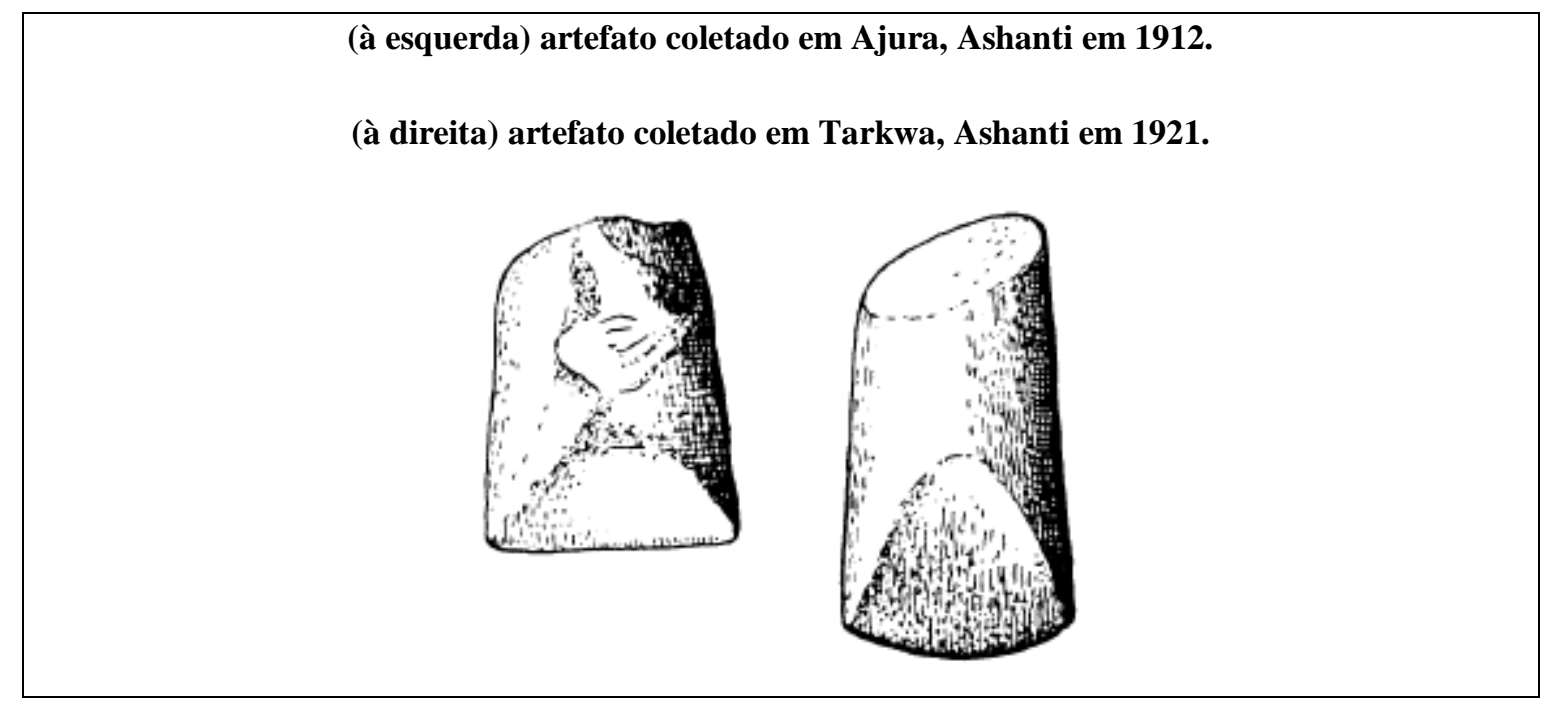

Fonte: BALFOUR, 1929, p.168.

Estruturalmente, o newsletter era composto por editorial, notícias sobre os trabalhos de campo e as pesquisas em andamento, além das informações sobre os congressos de Arqueologia da África e de áreas afins.

A edição do boletim NA produzida na University of Calgary, por ter o único departamento de arqueologia da América do Norte separado da Antropologia (NA, out.1972, n.1, p.1), passou a ocorrer na University of Alberta, ainda no Canadá (NA, dec.1988, n.30, p.1).

Observa-se, nas reproduções abaixo, a logomarca impressa no NA: um rinoceronte, que aparece na capa, desde o primeiro número. Já, na parte superior do editorial, somente a partir da edição de número trinta e dois. 
Figura 14 - Capa da primeira edição de outubro de 1972 e trecho do editorial do NA, n.32 de dezembro de 1989, com a logomarca.

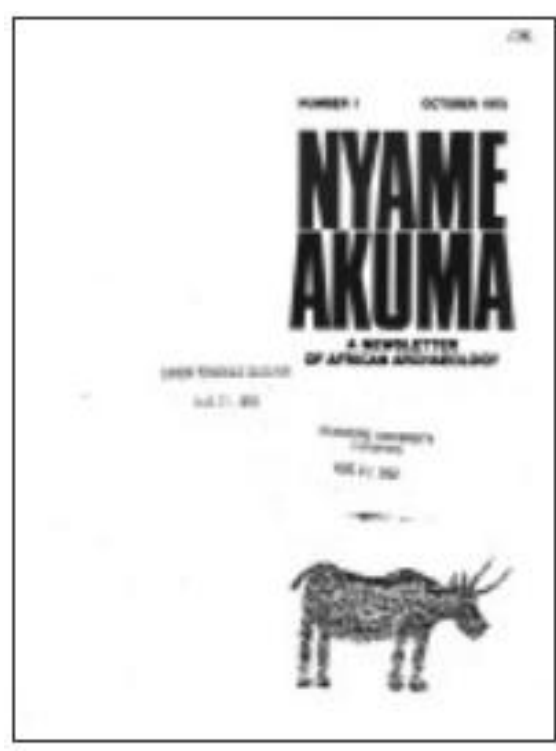

Fonte: GOOGLE BOOKS, acesso em $15 / 11 / 2012$.

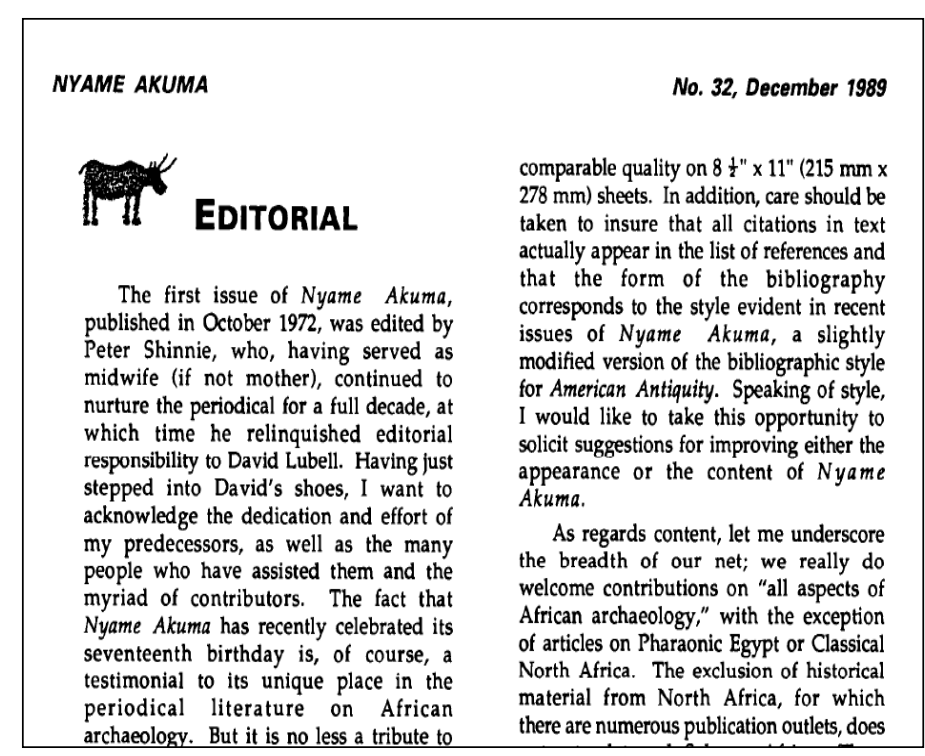

Fonte: SOCIETY OF AFRICANIST ARCHAEOLOGISTS b, acesso em 13/11/2012.

Shinnie, no primeiro editorial datado de outubro de 1972, explicou a adoção dessa logomarca:

O ícone na capa é de um desenho rupestre de um rinoceronte de Abka no Sudão e foi escolhido, em parte, porque eu pensei que além de ser encantador, eu queria prestar uma homenagem ao país que dediquei a maior parte da minha vida profissional. Se os leitores não gostarem nem do título nem do ícone eles podem ser alterados, mas eu usei o privilégio de editor para tomar as primeiras decisões. (NA, outubro 1972, n.1, p.1 - tradução livre) ${ }^{76}$

O nome do Nyame Akuma e a logomarca - rinoceronte da região de Abka - não foram alterados até, pelo menos, a edição de dezembro de 2008, a última com acesso aberto e gratuito.

De acordo com David (2008), segundo editor do newsletter, o arqueólogo processualista britânico e comunista Peter Lewis Shinnie (1915-

\footnotetext{
${ }^{76}$ The emblem on the cover is from a rock drawing of a rhinoceros from Abka in the Sudan and was chosen partly because I thought it rather charming and also because I wanted to pay tribute to the country in which most of my working life has been spent. If readers do not like either title or emblem they can be changed, but I have used the editor's privilege of making the first decisions. (NA, Oct. 1972, n.1, p.1)
} 
2007), primeiro editor do NA, especializou-se na arqueologia do Sudão, na construção de cronologias e no estudo das mudanças da cultura material nos sítios arqueológicos sob a ótica multidisciplinar. Em 1953, fundou a revista arqueológica Kush. Nessa mesma época, iniciou o ensino de arqueologia na Makerere University College, em Uganda (GABEL, 1985, p.260). Em 1958, tornou-se chefe do departamento de Arqueologia da University of Ghana - o primeiro da África Negra, no qual o ensino e a pesquisa de arqueologia operavam ativamente. Daí provém à justificativa de se colocar um artefato representativo de Gana para o nome do boletim Nyame Akuma.

Nesses anos, Shinnie solicitou ao presidente ganense Kwame Nkrumah, teórico da perspectiva pan-africanista, o patrocínio de um grupo de especialistas africanos, que seriam liderados por ele, para participar da expedição arqueológica de salvamento promovida pela UNESCO, para a construção da barragem de Aswan, situada no Rio Nilo, onde escavariam o importante sítio de Meroë (DAVID, 2008). Em 1966, trabalhou na University of Khartoum, no Sudão. Em 1970, devido à situação política desse país, que estava em guerra civil e tinha acabado de sofrer outro golpe militar, recebeu um convite para formar um departamento de arqueologia no Canadá. Assim, o arqueólogo mudou-se para a América do Norte.

Em 1972, começou a editar, em colaboração com a segunda esposa Ama Owusua Nantwi, o Nyame Akuma, de início denominado Newsletter e que, posteriormente, em 1990, foi renomeado para Bulletin. Foi editor do boletim até o ano de 1982. Trabalhou na University of Calgary, em Alberta, no Canadá, onde formou diversos arqueólogos canadenses que trabalharam na África e arqueólogos africanos que estudaram no Canadá.

Segundo David (2008, p.126), como editor do NA, Shinnie insistiu em enviar cópias gratuitas do newsletter para os "colegas do Terceiro Mundo que não tinham acesso à moeda forte [e] ele manteve as linhas de comunicação acadêmica abertas a todos aqueles que de outra forma teriam sido cortadas ${ }^{177}$ (tradução livre). Ainda segundo o autor, Shinnie, assim como Desmond Clark e

\footnotetext{
${ }^{77}$ His insistence that copies of Nyame Akuma be sent free to colleagues in the Third World who lacked acess to hard currency kept scholarly lines of communication open those who would otherwise have been cut off. (David, 2008, p.126-7)
} 
Thurstan Shaw, foram comprometidos com a "africanização da arqueologia" e com a maior participação dos especialistas expatriados.

Figura 15 - Peter L. Shinnie, s.d.

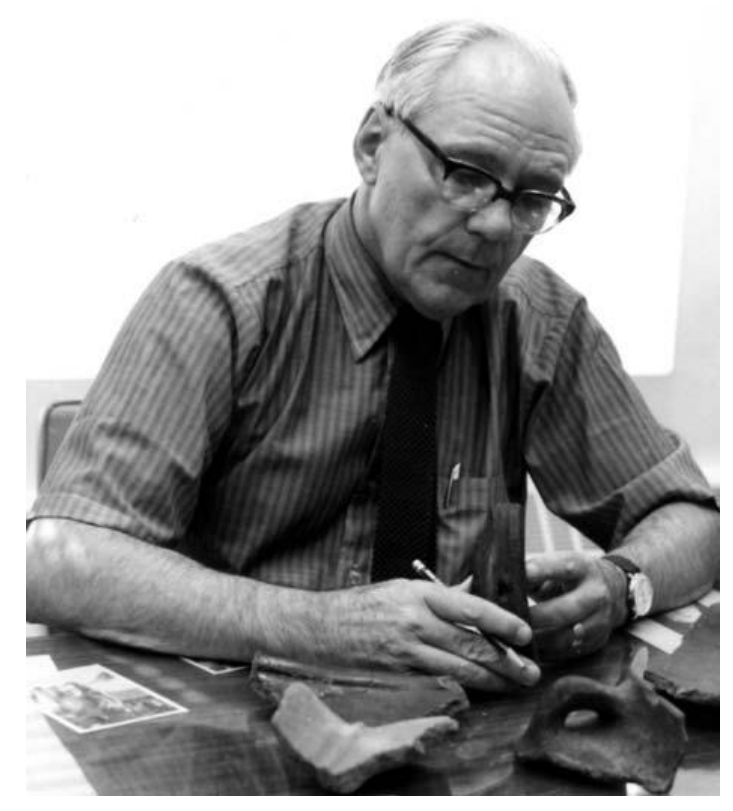

Fonte: DAVID, 2008, p.125.

\section{Os editoriais e os editores}

O editor David Lubell redigiu no editorial de abril de 1987:

Frank Kense [auxiliar do editor principal] mencionou em seu editorial de no 27 que a producão do NA está se tornando bastante onerosa. [...] Eu acho que um aumento [das assinaturas] para doze dólares por ano vai cobrir os custos. [...] As assinaturas gratuitas serão mantidas para aqueles que demonstrarem que são incapazes de obter moeda estrangeira. [...] O trabalho de produção do NA também vem se tornando um pouco mais fácil, pois a tecnologia de "desk top publishing" avança rapidamente. (NA, abril 1987, n.28, p.1 - tradução livre, grifos nossos) ${ }^{78}$

\footnotetext{
${ }^{78}$ Frank Kense mentioned in his Editorial for $\mathrm{n}^{\mathrm{o}} 27$ that the work of producing NA is becoming rather onerous. [...] I think an increase to $\$ 12 /$ year will cover costs. [...] Gratis subscriptions will continue to be sent to those who demonstrate that they are unable to obtain foreign currency. [...] The work of producing NA is also becoming somewhat easier as the technology of "desk top publishing" moves apace. (NA, April 1987, n.28, p.1)
} 
Observamos, nesse trecho, uma oposição entre duas situações: os custos de produção do NA e a informatização do processo editorial.

A primeira situação - os elevados custos de produção - é a causa da determinação de aumentar o preço das assinaturas anuais do NA, mas foi mantida a decisão de enviar o newsletter gratuitamente para os "incapazes de obter moeda estrangeira”. Essa elevação dos custos de produção deve-se à situação econômica descrita por Patterson (1999), das universidades e, por conseguinte, dos departamentos de arqueologia na década de 1980:

\begin{tabular}{l} 
A acumulação de capital em escala global expressou-se internamente \\
[nos países] em uma série de crises financeiras associadas com \\
saídas de capital e crescimento deficitário da balanca de comércio. \\
\hline As políticas monetárias lançadas nos anos 1970 e 1980 tentaram \\
resolver estas crises subordinando o Estado e a sociedade civil ao \\
poder do dinheiro no mercado. Internamente, os asseclas [lacaios] \\
políticos dos capitalistas desvalorizaram as moedas [...] Ao mesmo \\
tempo, após ajustes inflacionários, muitos orçamentos de faculdades \\
[departamentos] e universidades pararam de crescer ou havia \\
começado a declinar - uma condição que ainda persiste. \\
(PATTERSON, 1999, p.164 - tradução livre, grifos nossos)
\end{tabular}

No caso das economias da África, os arqueólogos africanos foram impactados com a desvalorização das moedas das nações e da elevação dos preços das assinaturas do Nyame Akuma, que dificultava o pagamento das taxas tratadas no trecho citado.

Esse editorial de abril de 1987 aponta que houve a continuidade da tentativa iniciada por Shinnie de conservar os arqueólogos africanos na rede de contatos e informações propiciadas pelo recebimento da publicação. Porém, percebemos no teor do editorial de Lubell desse ano, que essa condição de gratuidade estava ficando insustentável na produção e na distribuição do newsletter naquele momento.

Em dezembro de 1988, o editor Lubell comunicou sobre as decisões tomadas na reunião da SAfA (antiga SAAAm), em abril do mesmo ano, no Arizona, sobre a organização e os custos de manutenção do Nyame Akuma.

\footnotetext{
${ }^{79}$ The overaccumulation of capital on a global scale was expressed domestically in a series of financial crises associated with outflows of capital and growing balance-of-trade deficits. The monetarist policies launched in the 1970s and 1980s attempted to resolve these crises by subordinating the state and civil society to the power of money in the market. Domestically, the political minions of the capitalists devalued the currency. [...] At the same time, after adjustments for inflation, many college and university budgets stopped growing or had begun to decline - a condition that persists. (PATTERSON, 1999, p.164)
} 
Diante da situação financeira daquele momento, com cerca de mil e oitocentos dólares para produzir e distribuir o NA, e da assessoria ao longo de dois anos conseguida junto a University of Alberta Printing Services, Lubell escreve:

\begin{abstract}
Já não é possível efetivamente administrar o Nyame Akuma na forma que fizemos até agora. [...] A pedido de Peter Shinnie, incluo neste número uma lista de todos os assinantes atuais e gratuitos. [...] Eu gostaria que todos os leitores examinassem a lista das assinaturas gratuitas, tendo em mente a ideia excelente de David Killick [arqueólogo nascido no Malawi] que sugere que uma "solução (para o problema financeiro colocado pelas assinaturas gratuitas) poderia ser apelar para os assinantes pagantes da América do Norte (e de outros lugares?, ed.) para se voluntariar para pagar uma assinatura adicional cada um." Cada pagamento seria mantido em anonimato se o doador assim desejar. (NA, dezembro 1988, n.30, p.1 - tradução livre, grifos nossos) ${ }^{80}$
\end{abstract}

A lista, disposta nas páginas 48 a 53, daquela edição, era composta de 186 assinantes pagantes, 83 assinaturas canceladas e 37 assinantes gratuitos. Entre estas últimas assinaturas, que se tornaram um problema financeiro para o newsletter, há oito nomes de arqueólogos e museus pertencentes aos países do Leste Europeu. Portanto, 29 assinantes gratuitos são arqueólogos ou museus africanos, conforme consta na reprodução a seguir:

\footnotetext{
${ }^{80}$ It is no longer possible to manage Nyame Akuma effectively in the way we have had to until now. [...] At the request of Peter Shinnie, I include in this number a list of all current and gratis subscribers. [...] I would like all readers to examine the gratis list, bearing in mind an excellent idea from David Killick who suggests that a "solution (to financial problem posed by the gratis subscriptions) might be to appeal to paying subscribers in North America (and elsewhere?, ed.) to volunteer to pay for one additional subscription each". Such payments would remain anonymous if the donor wished. (NA, Dec. 1988, n.30, p.1)
} 


\begin{tabular}{|c|c|c|}
\hline \multicolumn{3}{|c|}{ CURRENT GRATIS SUBSCRIPTIONS } \\
\hline $\begin{array}{l}\text { B. AGBATE-WHLIAMS } \\
\text { INSTITUTE OF AFRICAN STUDIES } \\
\text { UNIVERSITY OF IBADAN } \\
\text { IBADAAN } \\
\text { NIGERIA }\end{array}$ & $\begin{array}{l}\text { DR AHMED EL HAKIM } \\
\text { DEPT OF ARCHAEOLOGY } \\
\text { UNIVERSITY OF KHARTOUM } \\
\text { KHARTOUM } \\
\text { SUDAN }\end{array}$ & $\begin{array}{l}\text { E.E. OKAFOR } \\
\text { DEPT OF ARCHAEOLOGY } \\
\text { UNIVERSITY OF NIGERIA } \\
\text { NSUKRA } \\
\text { NIGERIA }\end{array}$ \\
\hline $\begin{array}{l}\text { DR BASSEY WAI ANDAH } \\
\text { DEPT OF ARCHAEOLOGY } \\
\text { UNIVERSITY OF IBADAN } \\
\text { IBADAN } \\
\text { NIGERIA }\end{array}$ & $\begin{array}{l}\text { HERR F HINKEL } \\
\text { AKADEMIE DER WISSENSCHAFTEN } \\
\text { ZENTRAL INST FUR ALTEOESCHICHT } \\
108 \text { BERLIN } \\
\text { LEIPZIGERSTRASSE } 3 / 4 \\
\text { GDR }\end{array}$ & $\begin{array}{l}\text { ALEX I OKPOKO } \\
\text { DEPT OF ARCHAEOLOGY } \\
\text { UNIVERSITY OF IBADAN } \\
\text { IBADAN } \\
\text { NIGERIA }\end{array}$ \\
\hline $\begin{array}{l}\text { DR F ANOZIE } \\
\text { DEPT OF HISTORY AND ARCHAEOLOGY } \\
\text { UNIVERSITY OF NIGERIA } \\
\text { NSUKKA } \\
\text { NIGERIA }\end{array}$ & $\begin{array}{l}\text { PROF F HINTZE } \\
\text { BEREICH AGYPTOLOG } \\
\text { U SUDAN-ARCHAOLOG } \\
\text { HUMBOLDT UNIV } \\
\text { BERLIN N4 }\end{array}$ & $\begin{array}{l}\text { MR J G ONYANGO-ABUJE } \\
\text { DEPT OF ARCHAEOLOGY } \\
\text { UNIVERSITY OF IBADAN } \\
\text { IBADAN } \\
\text { NIGERIA }\end{array}$ \\
\hline $\begin{array}{l}\text { MR J ANQUANDAH } \\
\text { DEPT OF ARCHAEOLOGY } \\
\text { UNIVERSITY OF GHANA } \\
\text { PO BOX 3, LEGON } \\
\text { GHANA }\end{array}$ & $\begin{array}{l}\text { REINHARDSTRASSE } 7 \\
\text { GDR } \\
\text { DR. S. JAKOBIELSKI } \\
\text { UI SPACEROWA } 31 \\
\text { 05-805 OTREBUSY }\end{array}$ & $\begin{array}{l}\text { ALI OSMAN } \\
\text { DEPT OF ARCHAEOLOGY } \\
\text { UNIVERSITY OF KHARTOUM } \\
\text { KHARTOUM } \\
\text { SUDAN }\end{array}$ \\
\hline $\begin{array}{l}\text { MR I B BASSEY-DUKE } \\
\text { FEDERAL DEPT OF ANTIQUITIES } \\
\text { NATIONAL MUSEUM } \\
\text { JOS } \\
\text { NIGERIA }\end{array}$ & $\begin{array}{l}\text { POLAND } \\
\text { DAVID KIYAGA-MUINDWWA } \\
\text { DEPT OF HISTORY } \\
\text { UNIVERSITY OF BOTSWANA } \\
\text { PB } 22 \text { GABARONE }\end{array}$ & $\begin{array}{l}\text { KEITH RAY } \\
\text { DEPT OF ARCHAEOLOGY } \\
\text { UNIVERSITY OF NIGERIA } \\
\text { NSUKKA } \\
\text { NIGERIA }\end{array}$ \\
\hline $\begin{array}{l}\text { DR V E CHIKWENDU } \\
\text { DEPT OF HISTORY \& ARCHAEOLOGY } \\
\text { UNIVERSITY OF NIGERIA } \\
\text { NSUKKA } \\
\text { NIGERIA }\end{array}$ & $\begin{array}{l}\text { BOTSWANA } \\
\text { DR L KRZYZANIAK } \\
\text { MUZEUM ARCHEOLOGICZNE } \\
\text { UI WODNA } 27\end{array}$ & $\begin{array}{l}\text { SAYED NIGM ED DN MOHD SHERIF } \\
\text { DIRECTOR GENERAL OF ANTIQUITIES } \\
\text { PO BOX } 178 \text { KHARTOUM } \\
\text { SUDAN }\end{array}$ \\
\hline $\begin{array}{l}\text { MR CK COOKE } \\
\text { NATURAL HISTORY } \\
\text { MUSEUMM OF ZMMBABWE } \\
\text { PO BOX 240 } \\
\text { BULAWAYO } \\
\text { ZIMBABWE } \\
\text { MR LB CROSSLAND }\end{array}$ & $\begin{array}{l}\text { 61.781 POZNAN } \\
\text { POLAND } \\
\text { DR S LWANGA-LUNYIIGO } \\
\text { DEPT OF HSTORY } \\
\text { MAKERERE UNIVERSITY } \\
\text { PO BOX 7062 } \\
\text { KAMPALA } \\
\text { UGANDA }\end{array}$ & $\begin{array}{l}\text { DR EUGEN STROUHAL } \\
\text { NA VRCHMEZI 12 } \\
\text { 160 O0 PRAHA 6. SEDLEC } \\
\text { CZECHOSLOVAKIA } \\
\text { EL SHEIKH MAHMOUD EL TAYEB } \\
\text { SUDAN ANTIQUTTIES SERVICE } \\
\text { P.O. BOX } 178 \text { KHARTOUM } \\
\text { SUDAN }\end{array}$ \\
\hline $\begin{array}{l}\text { MR LB CROSSLAND } \\
\text { DEPT OF ARCHAEOLOGY } \\
\text { UNIVERSITY OF GHANA } \\
\text { IEGON } \\
\text { GHANA } \\
\text { ABI A. DEREFAKA }\end{array}$ & $\begin{array}{l}\text { UGANDA } \\
\text { DR F MASAO- } \\
\text { NATIONAL MUSEUM OF TANZANIA } \\
\text { PO BOX 511 } \\
\text { DAR ES SALAAM } \\
\text { TANZANIA }\end{array}$ & $\begin{array}{l}\text { SUDAN } \\
\text { DR SIMTYU WANDIBBA } \\
\text { DIVISION OF ARCHAEOLOGY } \\
\text { NATIONAL MUSEUMS OF KENYA } \\
\text { PO BOX } 40658 \text { NAIROBI } \\
\text { KENYA }\end{array}$ \\
\hline $\begin{array}{l}\text { DEPARTMENT OF ARCHAEOLOGY } \\
\text { UNIVERSITY OF IBADAN } \\
\text { IBADAN } \\
\text { NIGERIA } \\
\text { DR OMOTOSO EIUYEMI }\end{array}$ & $\begin{array}{l}\text { LEWIS MATTYELA } \\
\text { TRANSKEI NATIONAL MUSEUM } \\
\text { C/O DEPT OF EDUCATION } \\
\text { PO BOX } 3003 \text { UMTATA } \\
\text { TRANSKEI SOUTH AFRICA }\end{array}$ & $\begin{array}{l}\text { INSTITUTE OF ARCHAEOLOGY } \\
\text { UNIWERSYTET WARSZAWSKI } \\
\text { UL KRAKOWSKIE PRZEDMIESCHIE I } \\
\text { O0-047 WARSZAWA } \\
\text { POLAND }\end{array}$ \\
\hline $\begin{array}{l}\text { DR OMOTOSO EIUYEMI } \\
\text { DEPT OF HISTORY } \\
\text { UNIVERSTIY OF IFE } \\
\text { IIE IFE } \\
\text { NIGERIA. }\end{array}$ & $\begin{array}{l}\text { TRANSKEI, SOUTH AFRICA } \\
\text { MR A MTURI } \\
\text { DEPARTMENT OF ANTIQUITIES } \\
\text { BOX 2280 DAR ES SALAAM } \\
\text { TANZANIA }\end{array}$ & $\begin{array}{l}\text { POLAND } \\
\text { DR STEFFEN WENIG } \\
\text { 11-BERLIN-NIEDERSCHONHAUSEN } \\
\text { GRABBEALLEE } 46 \\
\text { GDR }\end{array}$ \\
\hline $\begin{array}{l}\text { DR EKPO EYO } \\
\text { DEPT OF ANTIQUITIES } \\
\text { NIGERIAN MUSEUM } \\
\text { LAGOS } \\
\text { NIGERIA }\end{array}$ & $\begin{array}{l}\text { MR J MYLES } \\
\text { EXEC SEC OMMSA } \\
\text { GHANA NATIONAL MUSEUM } \\
\text { P O BOX } 3343 \\
\text { ACCRA, GHANA }\end{array}$ & \\
\hline $\begin{array}{l}\text { DR W FILIPOWIAK } \\
\text { MUZEUM NARODOWE } \\
\text { SZCZECD } \\
\text { UL STAROML YNSKA } 27 \\
\text { POLAND } \\
\text { GHANA NATIONAL MUSEUM } \\
\text { PO BOX } 3343 \\
\text { ACCRA } \\
\text { GHANA }\end{array}$ & $\begin{array}{l}\text { DR N NZEWUNWA } \\
\text { UNIVERSITY OF PORT HARCOURT } \\
\text { EAST.WEST ROAD } \\
\text { CHOBA PMB S323 } \\
\text { PORT HARCOURT } \\
\text { NIGERIA } \\
\text { DR O ODAK } \\
\text { INSTITUTE OF AFRICAN STUDIES } \\
\text { UNIVERSITY OF NAIROBI } \\
\text { P O BOX } 30197 \text { NAIROBI } \\
\text { KENYA }\end{array}$ & \\
\hline
\end{tabular}

Fonte: NA, dez. 1988, n.30, p.53.

A justificativa para a gratuidade da assinatura é a falta de acesso dos assinantes africanos à moeda "forte" - dólar americano - para o seu pagamento. 
O editor John Bower apresentou as decisões tomadas na reunião da SAfA, em Gainsville, no início de 1990, publicadas no editorial datado de dezembro do mesmo ano:

\begin{abstract}
Infelizmente, os efeitos dessas dificuldades serão sentidas principalmente pelos assinantes não-americanos, especialmente aqueles que não têm acesso à moeda "forte", o que naturalmente inclui os assinantes em muitas nações africanas. [...] [As] edições gratuitas para os indivíduos ou para as instituições de países com "grandes" dificuldades monetárias serão enviadas pelo correio terrestre. [...] [O] Nyame Akuma não pode mais aceitar pagamentos de assinaturas em moeda não-americana por transferência bancária ou cheque pessoal. (NA, dezembro 1990, n.34, p.1 - tradução livre, grifos nossos)
\end{abstract}

Atentemo-nos para o uso da expressão "assinantes não-americanos" para identificar os arqueólogos africanos que recebiam o Nyame Akuma gratuitamente. Seu emprego denota a auto referência que o editor norteamericano faz na identificação dos arqueólogos que, de africanistas passam a ser nomeados como americanos ou pagantes e, de africanos, são denominados não-americanos ou não-pagantes. Nos editoriais de Lubell, entre 1987 e 1988, e Bower, de 1989 a 1993, a adoção desses termos para a identificação dos arqueólogos africanos e africanistas tem um contexto específico de aplicação, vinculado ao poder econômico, diferentemente do primeiro editorial de Shinnie, de 1972.

Bower, no editorial de dezembro de 1990, comunica uma mudança no prazo de submissão dos artigos ao boletim com o objetivo de que:

[...] isso irá incentivar o envio de contribuições (especialmente no outono do Hemisfério Norte) que de outra forma poderiam ser adiadas. (NA, dez. 1990, n.34, p.1 - tradução livre, grifos nossos) ${ }^{82}$

Devido à desvalorização das moedas das nações da África e os altos custos da produção e distribuição gratuita do boletim, os assinantes africanos passaram a receber o Nyame Akuma por correio terrestre. Como esse boletim

\footnotetext{
${ }^{81}$ Unfortunately, the effects of these stringencies will be felt mainly by non-U.S. subscribers, especially those who lack access to "hard" currency, which of course includes subscribers in many African nations. [...] free subscriptions to individuals or institutions in countries with "hard" currency difficulties will be sent surface mail. [...] Nyame Akuma can no longer accept subscription payments in non-U.S. currency by wire transfer or personal check. (NA, Dec. 1990, n.34, p.1)

${ }^{82}$ [T] his will encourage the submission of contributions (especially in northern hemisphere autumn) that otherwise might be deferred. (NA, Dec. 1990, n.34, p.1)
} 
chegava aos países em guerra civil, sem acesso a outras moedas e com problemas nas comunicações (cf. ROBERTSHAW, 1994), as "dificuldades sentidas" referiam-se à exclusão dos africanos da rede de circulação de informações sobre a Arqueologia da África propiciada pelo recebimento do boletim e colaboração com o envio das notícias sobre as pesquisas.

Conforme a construção discursiva dos trechos dos editoriais acima transcritos, vemos que, enquanto os arqueólogos africanos receberiam precariamente as informações sobre as pesquisas de campo e os congressos, os pesquisadores do hemisfério norte eram encorajados a publicar no NA. Um exemplo disso é o que aponta o enunciado - "isso irá incentivar o envio de contribuições (especialmente no outono do Hemisfério Norte)". Depois desse editorial, o editor Bower não retomou esse assunto do envio das edições para os "assinantes não-americanos", aparentemente dando por encerrada a questão com as soluções propostas pela SAfA e pelo conselho editorial.

Retomemos a oposição das duas situações construídas no editorial de Lubell de abril de 1987. A segunda situação - a informatização do processo editorial - foi relatada como um novo recurso, muito útil para a produção da publicação, que aliviaria os editores do trabalho de redigitar as contribuições e tornaria ágil a produção do newsletter. Nota-se, no conjunto editorial, que a preocupação com a adoção de novas tecnologias e com definição de padrões para a publicação progressivamente suplanta a inquietação com a inserção e a colaboração dos arqueólogos africanos no NA.

Nesse sentido, o editor Lubell e sua assistente Pamela Willoughby, dirigem-se para os leitores em dezembro de 1987:

Pouquíssimos autores estão realmente seguindo as orientações (ver "Notas para os Autores", na parte interna da capa frontal desta edição). [...] Por favor, lembre-se que o NA é um newsletter informativo, e não uma revista, e que é editado e produzido por duas pessoas [...] A próxima reunião da SAAAM será realizada em conjunto com a reunião anual da Society for American Archaeology em Phoenix, Arizona, em abril. (NA, dez. 1987, n.29, p. 1 - tradução livre, grifos nossos) ${ }^{83}$

\footnotetext{
${ }^{83}$ Very few contributors are actually following the guidelines (see the "Notes to Contributors" on the inside front cover of this issue). [...] Please remember that NA is a newsletter, not a journal, and that it is edited and produced by two people [...] the next SAAAM meetings will be held in conjunction with the
} 
Observamos nesse trecho que Lubell insiste no enquadramento dos arqueólogos às regras de publicação do newsletter para aliviar o editor da necessidade de redigitar as notícias das pesquisas de campo e excluir as ilustrações de má qualidade. Além disso, a preocupação com esse enquadramento se deve à busca de agilidade no fluxo editorial e na distribuição da publicação.

Segundo King e Tenopir (1998), a partir de 1970, projetos visando à automatização do processo editorial, o armazenamento e o acesso eletrônico aos artigos foram apenas parcialmente realizados, devido às limitações dos equipamentos, processadores e a resistência da comunidade científica em adotar um novo meio eletrônico para dar vazão à publicação de artigos.

Na década de 1980, disseminou-se o uso do disquete e do CD-ROM para armazenar as revistas científicas e a possibilidade de obter o texto on-line indexado pelas bases de dados bibliográficos. Na década de 1990, as redes eletrônicas de editoração e o acesso aos artigos eletrônicos tornam-se realidade. Quanto ao fluxo editorial, às divulgadoras científicas reduziram o tempo entre o recebimento do artigo, a apreciação dos pares - peer review - e a sua publicação e, também, a redução dos custos de produção e de distribuição.

Essa automação do fluxo editorial foi realizada no Nyame Akuma, sendo importante na medida em que o esforço despendido pelos editores, expresso nos editoriais, exprime uma tentativa de facilitar a comunicação científica entre os assinantes.

A recorrência ao tema das regras da publicação do newsletter e, depois no boletim, pode ser explicada, em uma primeira apreciação, pelo simples fato de que os arqueólogos africanistas e africanos não liam as instruções por desconsiderarem a novidade do processo editorial informatizado, já que muitos deles não tinham acesso às tecnologias computacionais solicitadas para a submissão dos trabalhos (cf. POSNANSKY, 1996).

annual meeting of the society for American Archaeology in Phoenix, Arizona next April. (NA, Dec. 1987, n.29, p. 1) 
Foi mantida pelos editores a função do boletim de informar aos leitores as reuniões da sociedade científica e as atividades dos colegas da área, como afirmou inicialmente Shinnie:

$O$ objetivo [de criar um Newsletter] é publicar rapidamente relatórios breves e originais de campo e outros projetos de pesquisa, bem como noticiar mais informalmente os movimentos e as atividades dos colegas. (N.A., outubro 1972, n.1, p. 1 - tradução livre, grifos nossos $)^{84}$

Em dezembro de 1992, o editor John Bower retoma os objetivos do NA: ‘...] publicar rápida e prontamente os relatórios dos trabalhos em curso [...]" (tradução livre) $^{85}$. Notamos que na construção discursiva do enunciado, Bower afirmava que o periódico continuava a desempenhar a função de responder à demanda de publicação das pesquisas e de interação entre os arqueólogos, cuja área de interesse era a África. Se não fossem seguidas as novas orientações para o envio das contribuições, na perspectiva de Lubell e, posteriormente, na do editor Bower, o Nyame Akuma, cada vez mais, perderia a sua característica de agilidade na produção e na distribuição das informações sobre as pesquisas arqueológicas e os congressos.

Nesse sentido, o editor Bower solicita:

Ajudaria se os autores preparassem seus manuscritos com o mesmo cuidado e atenção ao detalhe que seria de se esperar em uma apresentação para uma revista. [...] (NA, dez. 1989, n.32, p.1 tradução livre, grifos nossos) ${ }^{86}$

Eu ainda gostaria de pedir cuidado na preparação do manuscrito para o Nyame Akuma, particularmente atenção à bibliografia. (NA, dez. 1992, n.38, p.1 - tradução livre, grifos nossos) ${ }^{87}$

O objetivo mais direto desta pequena advertência é claro, para incentivar os autores a exercer um cuidado maior - na verdade, um nível profissional de cuidado - na preparação do material para 0 Nyame Akuma, especialmente quanto às citações. [...] Essa não é

\footnotetext{
${ }^{84}$ The aim being to publish quick brief and first reports on field and other research projects as well as to contain news of a more personal nature concerning the movements and activities of colleagues. (NA, Oct. 1972, n.1, p. 1)

85 “Given Nyame Akuma's mission to publish timely reports of ongoing work [...]” (NA, Dec. 1992, n.38, p.1)

${ }^{86}$ It will help if contributors would prepare their manuscripts with the same care and attention to detail that would be expected in a submission to a refereed journal. [...] (NA, Dec. 1989, n.32, p.1)

${ }^{87}$ [...] I would like to issue yet another plea for care in the preparation of manuscript for Nyame Akuma, particularly regards bibliography. (NA, Dec. 1992, n.38, p.1)
} 
apenas uma questão de etiqueta; ela está fundamentalmente ligada aos problemas de comunicação e, por isso, merece cautela. (NA, dez. 1993, n.40, p.1 - tradução livre, grifos nossos) ${ }^{88}$

Essa acuidade com a orientação dos autores sobre a informatização do processo editorial desdobrou-se na preocupação quanto às regras de envio de um artigo científico para uma revista especializada. Isso se deu graças a uma mudança na função da publicação.

Essa mudança se deu inicialmente transformando um "newsletter" da SAAAm, que informava, por meio de pequenas notas, as pesquisas arqueológicas em andamento e os congressos vindouros, direcionado para assinantes africanistas e africanos para um "boletim", entendido como "journal", da SAfA, com notícias mais aprofundadas e com referências bibliográficas padronizadas, direcionado para "assinantes pagantes".

Neste ponto, analisaremos os enunciados destacados nos trechos transcritos anteriormente, a fim de entender de que modo essas mudanças na função da publicação e nas alterações das condições das assinaturas gratuitas do NA vinculam-se à construção da imagem dos arqueólogos africanistas e africanos nesses editoriais.

Os editoriais do NA, entre os anos de 1987 e 1993, apresentavam as seguintes recorrências na arquitetura discursiva:

i) O destaque contínuo à carência de "moeda forte" dos arqueólogos e instituições africanas;

ii) A carência da "moeda forte" por parte dos arqueólogos africanos foi interpretada pelos editores como um problema de ordem financeira que impossibilitava a continuidade da distribuição gratuita do newsletter;

iii) A acepção dos arqueólogos africanistas da América do Norte e de outros lugares como patrocinadores das assinaturas gratuitas dos africanos; e

\footnotetext{
${ }^{88}$ The most direct purpose of this little diatribe is of course, to encourage authors to exercise greater care - indeed, a professional level of care - in preparing material for Nyame Akuma, especially as regards citations. [...] This is not just a matter of etiquette; it is fundamentally related to problems of communication and thus deserves very careful attention. (NA, Dec. 1993, n.40, p.1)
} 
iv) A determinação da SAfA de enviar as publicações por via terrestre para os africanos e dos pagamentos somente em "moeda forte" em meio à instabilidade econômica na África.

Decorre disso, a nosso ver, a lógica essencial para a construção das imagens que foi concomitante à construção de um boletim com produção editorial tecnológica e mais rigorosa, seguindo as normas de um boletim científico - "journal" - ligado a uma sociedade científica.

Observemos acuradamente, no quadro a seguir, a lógica desse discurso empregada nos enunciados dos editoriais que formam, em última análise, as imagens dos arqueólogos africanistas e africanos. Estes últimos com assinaturas gratuitas passaram de colaboradores para dependentes.

\section{Imagem 1: Africanos - carência - problema}

Enunciado identificador: "As assinaturas gratuitas serão mantidas para aqueles que demonstrarem que são incapazes de obter moeda estrangeira." (editor Lubell, NA, abril 1987, n.28, p.1)

Enunciado identificador: Lista "Current Gratis Subscriptions" (editor Lubell, NA, dez. 1988, n.30, p.53).

\section{$+$}

Enunciado identificador: "dificuldades serão sentidas principalmente pelos assinantes não americanos, especialmente aqueles que não têm acesso à moeda "forte", o que naturalmente inclui os assinantes em muitas nações africanas." (editor Bower, NA, dez. 1990, n.34, p.1)

\section{versus}

\section{Imagem 2: Africanistas - suficiência - solucão}

Enunciado identificador: "solução (para o problema financeiro colocado pelas assinaturas gratuitas) poderia ser apelar para os assinantes pagantes na América do Norte" (editor Lubell, NA, dez. 1988, n.30, p.1)

Enunciado identificador: Lista "Current Paid Subscriptions" (editor Lubell, NA, dez. 1988, n.30, p.48-52).

A construção imagética dos arqueólogos africanos e africanistas nos editoriais do boletim NA, entre os anos de 1987 a 1993, opera-se no uso de 
enunciados, palavras e frases, que associam o arqueólogo idealizado - o assinante pagante, leitor e autor - ao poder econômico de dispor de uma "moeda forte" incentivando a cota de assinaturas de arqueólogos africanos colaboradores e receptores da publicação. Devemos nos atentar que, na visão dos editores, o especialista tido como ideal colabora para a manutenção do boletim de duas formas: efetua o pagamento de suas assinaturas e patrocina aqueles que não podem pagar, diante da impossibilidade monetária dos 37 assinantes "carentes", sendo 29 africanos.

Assim, deduz-se que a imagem construída dos arqueólogos nos editoriais do Nyame Akuma associa-se a um quase "paternalismo" em prol do bem comum: a manutenção do orçamento financeiro do newsletter, posteriormente, do boletim e a permanência da cota de assinaturas gratuitas dos africanos. Segundo a antropóloga Goodell (1985):

Paternalismo é interferir na autonomia de alguém ou de algum grupo com a justificativa de zelar unicamente pelo bem estar, pela felicidade, pelas necessidades, pelos interesses ou pelos valores desse alguém ou desse grupo. (GOODELL, 1985, p.247 - tradução livre $)^{89}$.

Relembremos que a SAAAm, posteriormente renomeada para SAfA, era uma instituição de caráter informal na sua origem e lançou um newsletter que visava congregar os arqueólogos norte-americanos pretendendo, com isso, alcançar a totalidade dos especialistas interessados, cujo local de pesquisa era a África. Essa sociedade científica, a qual prezava a informalidade das reuniões e da organização estatutária dos seus membros, ou seja, a autonomia dos pesquisadores associados, aspecto apontado nos primeiros editoriais do NA, muda esse princípio aparentemente em função de um fator externo importante: a carência monetária dos africanos. Essa mudança de perspectiva, expressa nos editoriais do corpus, revela a força de intervenção dos pagantes sobre os não-pagantes. De outro modo, essa transformação de entendimento revelou-se na alteração da forma de distribuição do newsletter, desmantelando a rede de comunicação que era estabelecida pela antiga estrutura de distribuição da publicação.

\footnotetext{
${ }^{89}$ Paternalism is interference with other's autonomy justified by reasons referring exclusively to their welfare, good, happiness, needs, interests, or values. (GOODELL, 1985, p.247)
} 
O conceito de "paternalismo" de Goodell (1985), com alguma modificação, na nossa análise, reflete-se na prática discursiva dos editores que acentuam a benevolência do doador - o arqueólogo "não-africano" - sobre o receptor - o especialista africano - do benefício ou pagamento das assinaturas do NA. Dessa forma, os arqueólogos africanos, como exposto nos enunciados do quadro acima, são enfatizados como aqueles que precisavam de auxílio dos "não-africanos" para efetuar a contribuição e, assim, continuar a receber a publicação.

Na nossa perspectiva, se durante a colonização do continente africano, no século XIX, "a missão civilizadora" era um argumento paternalista para a ação benevolente dos colonizadores, nota-se, nesses enunciados, que há a exploração do argumento da dependência econômica para o auxílio dos "nãoafricanos", a fim de que a arqueologia feita por africanos seja incentivada e publicada.

Seguindo o mesmo teor do raciocínio dos editores, Schmidt (1995) afirma:

[As] raízes dessa marginalidade e dependência [dos arqueólogos africanos] são profundamente relacionadas com a ausência de riqueza suficiente para a produção africana e a disseminação desse conhecimento em todo o mundo. (SCHMIDT, 1995, p.123) (0 $^{\circ}$

Nota-se nessa assertiva que a opinião de Schmidt é semelhante a dos editores: prevalência do poder econômico na produção e publicação dos estudos arqueológicos realizados por africanos. $\mathrm{O}$ argumento utilizado sobre a necessidade de colaboração monetária para custear as assinaturas gratuitas e a exposição de uma lista com todos os assinantes gratuitos, desperta-nos para a explicação que retomamos de Goodell (1985, p. 252) sobre a natureza ideológica e psicológica das relações paternalistas: "[os] paternalistas podem exigir periodicamente que seus 'beneficiários' provem (ou ao menos divulguem) a sua fraqueza publicamente [...]" (tradução livre) ${ }^{91}$. Assim, os editores

\footnotetext{
${ }^{90}$ The roots of this marginality and dependence are profoundly related to the absence of sufficient wealth for the production of African knowledge and the dissemination of that knowledge throughout the world. (SCHMIDT, 1995, p.123)

${ }^{91}[\ldots]$ these paternalists may periodically require their 'beneficiaries' to prove (or at least advertise) their weakness publicly $[\ldots]$ (GOODELL, 1985, p.252)
} 
reproduzindo um argumento paternalista da mentalidade colonial, elaboraram uma imagem dos arqueólogos africanos em uma posição inferiorizada em comparação aos africanistas, detentores da "moeda forte". Vemos como as condições dos assinantes - pagantes e não-pagantes - implica na construção da imagem dos arqueólogos.

Essa ideia associa-se ao fato de que, entre as décadas de 1980 e 1990, a arqueologia africana caracterizou-se por uma precária estrutura de pesquisa de campo, laboratorial e acadêmica. Posnansky (1996), nesse sentido, afirma:

Ao longo da década de 1980 e, particularmente, no final dela, com o fim da Guerra Fria, a África tornou-se cada vez mais marginalizada, com diminuição dos subsídios afetando as instituições africanas. [...] A maior parte dos departamentos de arqueologia tem sido incapaz de compartilhar as vantagens da revolução eletrônica e dos computadores que tem transformado a Arqueologia fora da África. [...] Com muita frequência muitos dos pesquisadores estrangeiros são os próprios alunos de pós-graduação, trabalhando com recursos limitados e usando, mas nem sempre substituindo, os escassos equipamentos de campo e, além do mais, exportando seus achados para estudo no exterior. ${ }^{22}$ (POSNANSKY, 1996, p.149 - tradução livre)

Queremos expressar com essa explanação que, até 1987, a sociedade científica era um "grupo corporativo" tendo "uma organização interna e um conjunto definido de relações externas e de interesses, autonomia e procedimentos adequados para regulamentar o grupo" (SMITH apud GOODELL, 1985, p.249 - tradução livre ${ }^{93}$. Em nosso recorte temporal, depreendemos, de acordo com os editoriais analisados, que havia a necessidade de intervir em uma situação eminentemente prejudicial para a manutenção do boletim e para o projeto de remodelação, redirecionando para uma publicação mais regular e rigorosa, ou seja, um "journal”. Essa intervenção, a nosso ver, tem um fundo paternalista, o qual espelha uma

\footnotetext{
${ }^{92}$ Throughout the 1980, and particularly at the end of the decade with the end of the cold war, Africa became increasingly marginalized, with donor fatigue affecting grants to African institutions. [...] Departments of archaeology have for the most part been unable to share in the advantages of the electronic revolution and computers that have so transformed archaeology of outside Africa. [...] All too frequently many of the foreign researchers have been graduate students working with limited funds themselves, using but not always replacing scarce fieldwork equipment and exporting their finds abroad for study. (POSNANSKY, 1996, p.149)

${ }^{93}$ Smith $[\ldots]$ describes a corporate group as an "enduring, presumably perpetual group with determinate boundaries and membership, having an internal organization and a unitary set of external relations, an exclusive body of common affairs, and autonomy and procedures adequate to regulate them."' (GOODELL, 1985, p.249)
} 
mentalidade colonial, pois os mais prejudicados, ao fim e ao cabo, foram os arqueólogos africanos que, pelas novas condições de distribuição da publicação e de assinatura paga, poderiam ser excluídos da rede formada.

Essa adoção do posicionamento paternalista, por parte dos editores e dos membros da sociedade, interviu na construção das imagens dos arqueólogos africanistas e africanos veiculadas na Nyame Akuma. Nos primeiros editoriais do newsletter, ambos possuíam o mesmo nível de importância na produção e na divulgação do conhecimento, o que é visível no esforço de Shinnie em estabelecer a rede de comunicação entre eles com o envio das edições para os africanos.

Posteriormente, nos editoriais do período analisado, os africanos apareceram, conforme assinalamos nos trechos dos editoriais, em posição inferiorizada na produção e na divulgação do conhecimento na publicação.

A partir da edição de dezembro de 1988, reviu-se a questão da gratuidade das assinaturas do NA aos especialistas e instituições africanas, com a sugestão do editor Lubell do pagamento voluntário das assinaturas dos arqueólogos não-africanos para os africanos. Em edição de dezembro de 1990, o editor Bower informa que o conselho editorial enviaria a publicação para os assinantes gratuitos dos países africanos por via terrestre e com pagamento somente em "moeda forte".

Com isso, os assinantes africanos acabariam por serem distanciados da rede criada pelo NA. Todavia, os editores alegavam que o fator responsável pelo enxugamento dos gastos da publicação era a crise econômica vivenciada pelo Nyame Akuma e não apenas a já existente derivada do "fato colonial" da África, a qual repercutia, em última análise, na impossibilidade de pagamento das assinaturas pelos arqueólogos africanos.

Dessa forma, os editoriais do NA passaram a apresentar discursos apartados da vida social, política e econômica da África, nos quais os arqueólogos africanos e africanistas inseriam-se. Isso não se deve à situação política do Canadá, onde a publicação é editada desde 1972. Nem a dos Estados Unidos, onde as assinaturas do NA realizavam-se e que poderia 
censurar as manifestações críticas dos arqueólogos norte-americanos. Devese, sim, ao posicionamento ideológico e corporativo da SAfA e do conselho editorial do Nyame Akuma.

Como já mencionamos nos capítulos um e quatro, são muitas as variantes que compõem o jogo de ideias sobre a construção da imagem do arqueólogo. Alguns deles determinados pelos editores e de onde escrevem.

Então, direcionemos nosso olhar a eles novamente.

David Lubell foi editor do NA entre os anos de 1982 e 1988. Enquanto era editor do newsletter, lecionava na University of Alberta, no Canadá. Os editores Shinnie e Nicholas David, anteriores ao período correspondente ao nosso recorte temporal, também eram docentes na mesma província canadense. Entre os anos de 1989 e 1999, Lubell foi chefe do Departamento de Antropologia dessa Universidade. Suas principais áreas de interesse são: o final do período Pleistoceno e o início do Holoceno, no Mediterrâneo Ocidental, no sul da Europa e na região do Magreb, no norte da África. Especializou-se no estudo interdisciplinar das relações entre os homens e o meio ambiente (UNIVERSITY OF WATERLOO a, acesso em 16/11/2012). Logo, o editor passou a ser especialista do norte da África, considerado parte da cobertura espacial "elástica" do NA, ou seja, todo o continente africano desde que tratado na perspectiva da "pré-história".

Figura 16 - David Lubell, s.d.

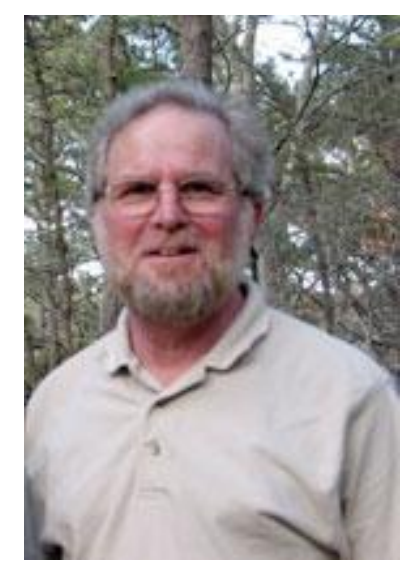

Fonte: UNIVERSITY OF WATERLOO b, acesso em 16/11/2012. 
John R. F. Bower, editor do boletim NA entre os anos de 1989 e 1993, formou-se em Geologia em Harvard. Pós graduou-se na Northwestern University, com uma pesquisa em Nairóbi, no Quênia. Entre os anos de 1974 a 1992, lecionou na lowa State University e, desde 1993, até a presente data, leciona antropologia biológica e cursos relacionados à sua pesquisa de campo, no Quênia, na University of Minnesota, campus Duluth. (UNIVERSITY OF MINNESOTA, acesso em 16/11/2012).

Figura 17 - John R. F. Bower, s.d.

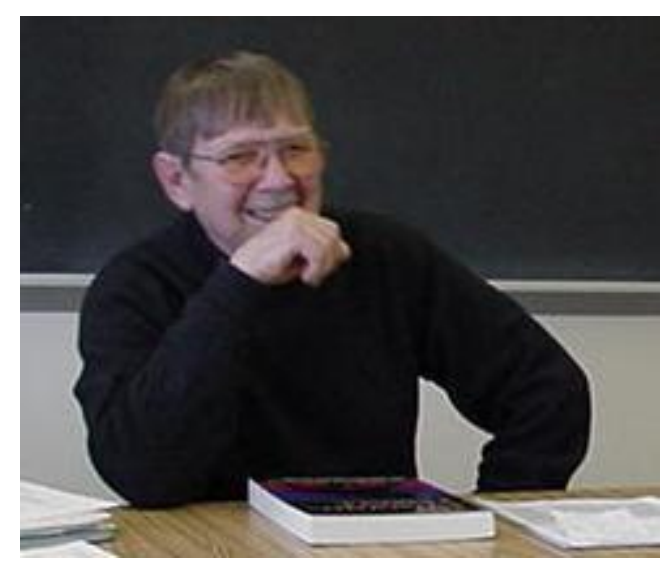

Fonte: UNIVERSITY OF MINNESOTA, acesso em 16/11/2012.

\section{Para que serve o "newsletter" e, posteriormente, o "bulletin"?}

Destacamos que os três primeiros editores do Nyame Akuma, incluindo Lubell, eram oriundos dos departamentos de arqueologia do Canadá, enquanto que o último editor, Bower, era vinculado aos Estados Unidos.

Tratemos da história da arqueologia africanista na América do Norte antes de retomar a análise dos editoriais e dos editores acima apresentados.

Kelley e Williamson (1996) ao traçar uma comparação entre a arqueologia do Canadá e dos Estados Unidos constatam semelhanças nas abordagens e algumas diferenças nas trajetórias históricas. A primeira diferença refere-se à antiguidade do estabelecimento da arqueologia profissional nos países, medida pela criação de associações correspondentes. 
A American Philosophical Society e a American Antiquarian Society, ambas interessadas na origem dos antigos montes localizados no interior dos Estados Unidos, surgiram no final do século XVIII e início do século XIX. O Canadian Institute foi estabelecido em 1851 e deu origem à publicação Canadial Journal centrada nos textos dos "pré-historiadores" europeus. Outras publicações arqueológicas circularam nos dois países na segunda metade do século XIX e na primeira metade do século XX (KELLEY e WILLIAMSON, 1996, p.6-7).

Nos Estados Unidos, a segunda metade do século XX, logo após a Segunda Guerra Mundial, foi marcada pelo crescimento vertiginoso do número de arqueólogos profissionais membros de sociedades científicas estadunidenses (PATTERSON, 1990, p.162-3). O Canadá beneficiou-se com a afluência de especialistas norte-americanos e britânicos para formar os departamentos de arqueologia e treinar os jovens arqueólogos canadenses. Já, a década de 1960 caracterizou-se pela falta de consenso metodológico no Canadá, pelo estabelecimento de arqueólogos estrangeiros, pela manutenção da abordagem histórico-culturalista e pela adoção da perspectiva teórica dominante da arqueologia estadunidense, a Nova Arqueologia. Segundo Kelley e Williamson (1996):

[É] verdade que a arqueologia canadense sempre teve seus laços externos mais próximos dos Estados Unidos, apesar de que nós poderíamos dizer que, as tradições intelectuais britânicas e europeias $e$ os modelos estruturais disciplinares são mais fortemente representadas no Canadá do que nos Estados Unidos. Isto pode ser especialmente verdadeiro para aqueles arqueólogos das universidades canadenses que trabalham no exterior e mantêm filiações secundárias com instituições e agências fora do Canadá. (KELLEY e WILLIAMSON, 1996, p.10 - tradução livre) ${ }^{94}$

Em meio a esse contexto, a Universidade de Calgary, no Canadá, onde foi feita inicialmente a edição do Nyame Akuma, com um departamento de arqueologia separado da antropologia, ilustra claramente essa tentativa da arqueologia canadense de apresentar características próprias em comparação com os Estados Unidos. Assim, podemos considerar que os editores do NA,

\footnotetext{
${ }^{94}$ Nonetheless, it is true that Canadian archaeology has always had its closest external ties to the United States, although, we would argue, British and European intellectual traditions and structural disciplinary models are more strongly represented in Canada than in the United States. This may be especially true for those archaeologists in Canadian universities who work abroad and maintain secondary affiliations with institutions and agencies outside of Canada. (KELLEY e WILLIAMSON, 1996, p.10)
} 
eram frutos dessa trajetória da arqueologia canadense: Peter L. Shinnie aprendeu egiptologia em Oxford; Nicholas David estudou nas universidades de Cambridge e Harvard; e, David Lubell formou-se na Columbia University. Estes três editores formaram e ajudaram a consolidar os departamentos arqueológicos no Canadá, cuja trajetória integra também o renomado arqueólogo canadense Bruce G. Trigger, que atuou na construção de uma arqueologia com uma abordagem independente da corrente majoritária estadunidense (KELLEY e WILLIAMSON, 1996).

A SAfA, criada no início da década de 1970, congrega os arqueólogos da América do Norte e reflete esses "laços externos" que possibilitaram a edição do newsletter na University of Calgary e, posteriormente, em Alberta, ambas canadenses, e o pagamento da taxa das assinaturas na University of Florida, Gainsville, nos Estados Unidos, no período analisado.

Em seus editoriais, Bower apresenta posicionamentos pragmáticos com a sobrevalorização da comunicação científica marcada pela neutralidade sobre qualquer assunto ligado à vida social, política ou econômica dos arqueólogos africanos e africanistas. Podemos exemplificar esse aspecto pelos trechos dos editoriais dos meses de dezembro dos anos de 1989, de 1992 e de 1993, entre outros já transcritos nesse capítulo e no capítulo um.

Segundo Trigger (2004), a Nova Arqueologia, corrente metodológica amplamente difundida e consolidada nas décadas de 1950, 1960, com Binford, a 1980, entre os arqueólogos norte-americanos, também angariou adeptos no continente africano, como no caso dos editores do boletim TSAAB. O principal foco de abordagem dos especialistas dessa vertente, também intitulada processualista, seria entender e descrever como ocorrem "as mudanças das culturas arqueológicas em termos de processo cultural" (TRIGGER, 2004, p.286). O estudo do comportamento cultural e das suas mudanças registradas no legado material em contexto arqueológico parte de uma perspectiva "interna”, específica para abordar a dada tradição pretérita, em contraposição à perspectiva "externa" difusionista ou histórico-culturalista.

A abordagem processualista origina-se do entendimento da dinâmica da cultura enquanto um sistema no qual as partes funcionam articuladamente. 
Qualquer alteração em uma delas implicaria na modificação de um todo. Conhecendo-se o modo de funcionamento dessas partes, poder-se-ia estabelecer as regularidades da cultura pretérita e descrever as regras das suas transformações (TRIGGER, 2004). Nas palavras de Binford (1964):

Como os sistemas culturais se tornam mais complexos, eles geralmente abrangem maiores [recursos] ecológicos e entram em uma interação mais complexa, generalizada, extrasocietal. 0 isolamento e a definição do conteúdo, da estrutura, e o amplitude de um sistema cultural, juntamente com a suas relações ecológicas, podem ser vistos como os objetivos de investigação.

(BINFORD, 1964, p.426 - tradução livre) $)^{95}$

Para tanto, os processualistas partiam de uma abordagem positivista, de defesa da neutralidade científica e pragmática. Segundo Trigger (2004):

A aplicação rigorosa de um enfoque positivista foi vista como uma forma de eliminar os elementos subjetivos e estabelecer uma base para a interpretação objetiva, científica, dos dados arqueológicos. (TRIGGER, 2004, p.293)

E mais,

Basicamente, a orientação nomotética [proponente de leis], da Nova Arqueologia apelava para as tendências desses americanos a valorizar o que é tecnologicamente útil [...].(TRIGGER, 2004, p.305)

Logo, destacamos que os editoriais do corpus documental do Nyame Akuma apresentaram gradativamente um acirramento dessa abordagem pragmática com 0 recorrente destaque dado ao processo editorial informatizado, muito útil, segundo os editores Lubell e Bower, para a melhoria da peridiocidade e da qualidade da publicação com vistas ao progresso da ciência arqueológica. A defesa da neutralidade científica, enfim, da abordagem positivista, é apontada nos editoriais com o progressivo silenciamento dos editores sobre os contextos sociais, políticos e econômicos em que os arqueólogos inserem-se, principalmente os africanos. Nesse sentido, Patterson (1986) afirma:

O positivismo lógico contribuiu com a linguagem do discurso arqueológico; no entanto, essa natureza do conteúdo desse discurso

\footnotetext{
95 As cultural systems become more complex, they generally span greater ecological ranges and enter into more complex, widespread, extrasocietal interaction. The isolation and definition of the content, the structure, and the range of a cultural system, together with its ecological relationships, may be viewed as a research objective. Admittedly it is an objective which may or may not be successfully accomplished under any given research design. (BINFORD, 1964, p.426)
} 
transferido foi moldada pelos debates mais amplos da sociedade norte-americana, aquelas em que os arqueólogos participaram apenas perifericamente. Como resultado, eles foram marginalizados em certa medida na ciência social. (PATTERSON, 1986, p.16-17 tradução livre) $)^{96}$

Trigger (1984) nomeia como "colonialista" a orientação da Nova Arqueologia, pautada nessa alegada neutralidade científica, utilitarista e silenciosa. Essa última característica, a do silenciamento, mascara a dificuldade da divulgação do conhecimento arqueológico produzido por africanos no NA, a introspecção da sociedade SAfA e do boletim, cujo texto editorial passou a focar no obedecimento de rigorosos critérios para a publicação ser considerada um "journal" pelos pares.

Um fato interessante para a nossa análise é que os arqueólogos africanos continuavam enviando e publicando as notícias das suas pesquisas de campo no NA no período do nosso recorte temporal. Isso demonstra que não havia desigualdade na qualidade dos textos de africanos e não-africanos que foram revisados com critérios de uma publicação mais rigorosa ("journal"), mesmo com as dificuldades financeiras que obstacularizavam 0 desenvolvimento da arqueologia africana.

As práticas discursivas presentes nos editoriais do corpus documental dos anos de 1987 e 1993 apontam para uma mudança considerável na função do NA a qual se vincula à construção das imagens dos arqueólogos. Nos primeiros editoriais, escritos por Shinnie, às imagens relativas aos africanos e africanistas eram equiparadas enquanto produtores de conhecimento sobre arqueologia da África.

Houve, no período analisado, uma mudança nessas imagens veiculadas denotando uma dificuldade dos africanos de publicarem o conhecimento arqueológico produzido devido às crises econômicas dos países da África. Essa situação econômica, enquanto fator externo à produção do conhecimento científico revelou-se um dificultador, na interpretação dos editores, na manutenção das assinaturas dos arqueólogos africanos e, portanto, no

\footnotetext{
${ }^{96}$ Logical positivism provided the idiom for archeological discourse; however, the nature of this discourse was shaped by wider debates in U.S. society, ones in which archeologists participated only peripherally. As a result, they were marginalized to some extent in the social sciences. (PATTERSON, 1986, p.16-17)
} 
estabelecimento da rede de contato de arqueólogos africanos e africanistas promovida pelo newsletter.

Foram anos cruciais aqueles que analisamos dentro do período do nosso recorte temporal, marcados pelo impacto do World Archaeological Congress de 1986, no qual ocorreram à inclusão dos especialistas e comunidades nativas do "Terceiro Mundo" e a exclusão dos arqueólogos sulafricanos em função do boicote ao regime segregacionista do mesmo congresso (UCKO, 1987), fatos reportados no capítulo anterior. Nesse interim, couberam, ainda, os debates promovidos pelos teóricos pós-coloniais (FOUCAULT, 1972, SAID, 2005) e os especialistas da arqueologia pósprocessual (HODDER, 1989, 1996 e 2003).

Apesar disso, os editoriais do NA fortaleciam a consolidação de um "boletim" publicado de forma mais rigorosa, priorizando a comunicação científica daqueles que pudessem pagar pela assinatura.

Essa decisão denota a mudança na função social do newsletter, anteriormente de interação entre os arqueólogos da América do Norte e das regiões da África, para a função tradicional de um "boletim" de difusão dos conhecimentos ratificados pelos arqueólogos nos padrões estabelecidos pela sociedade científica. O boletim teria, como função remodelada, o progresso da ciência arqueológica produzida sobre a África, para assinantes pagantes e aqueles africanos que recebessem o patrocínio do pagamento da assinatura.

Consideramos que a forma de estruturação e veiculação imagética de arqueólogos africanos ou "não-americanos" e africanistas ou "não-africanos" são consequências do paradigma ideológico relativo à mentalidade colonial que nutre a desigualdade na produção e divulgação do saber entre ambos. Essa desigualdade revela-se na construção das imagens desiguais dos arqueólogos africanos e africanistas. 


\section{NSI - BULLETIN DE LIAISON DES ARCHÉOLOGUES DU MONDE BANTU}

[O]s arqueólogos devem procurar informar e aconselhar os governos africanos e as organizações mundiais do significado cultural da arqueologia no desenvolvimento dos cidadãos africanos com senso de enraizamento, pertencimento social e importância. (HASSAN, 1999, p.404) $)^{97}$

\section{A Sociedade e o Boletim}

O Nsi - Bulletin de Liaison des Archéologues du Monde Bantu (Nsi) foi lançado em 1987, como uma publicação do Departamento de Arqueologia do Centre International des Civilisations Bantu (CICIBA), sediado em Libreville, no Gabão. O boletim era publicado semestralmente, nos meses de maio e novembro, porém, nos dois últimos anos da sua circulação, 1991 e 1992, tornou-se anual com a junção de duas edições, respectivamente, os números oito-nove e dez-onze.

Os editores do Nsi, entre o ano de lançamento e o ano de 1991, foram Bernard Clist e Raymond Lanfranchi. Entre 1992 e 1993, o primeiro foi o responsável pelo seu processo editorial até que o boletim fosse incorporado ao Nyame Akuma, na edição deste de número trinta e nove de junho de 1993.

O diretor geral do CICIBA, até 1991, foi Théophile Obenga, que assinou o primeiro editorial do corpus documental composto de sete editoriais (PHILLIPSON, 1988; SAN FRANCISCO STATE UNIVERSITY, acesso em 16/12/2012). O diretor da pesquisa, Bayona-ba-Meya, grafou os editoriais números dois, de 1987 e três, de 1988 ( $N s i, 1989$, n.6, p.178). As edições número quatro do ano de 1988 e número sete de 1990 não apresentaram editoriais.

\footnotetext{
$97[\ldots]$ archaeologists should aim to inform and advise African governments and world organizations of the cultural significance of archaeology in the development of African citizens with sense of roots, social belonging and importance. (HASSAN, 1999, p.404)
} 
O CICIBA teve três revistas científicas. A primeira é a Muntu: Revue Scientifique et Culturelle du CICIBA (1984) - "muntu" significa "pessoas" (SALUM, 1996), cuja publicação trata de etnografia, antropologia cultural e arqueologia, sendo editada por Théophile Obenga e os seus últimos registros localizados por nós datam de 1988 (DUFAU, 1988, p.134). A segunda é o Nsi (1987), que nos debruçamos neste capítulo. A terceira é o Kala-Kala: Bulletin du Groupe des Recherches Archéologiques au Congo (1988), boletim que não localizamos nenhuma edição publicada e seria lançado com o apoio da Missão Francesa de Ajuda e Cooperação (CLIST e LANFRANCHI, 1989, p.147). Além dessas revistas, o CICIBA publicou livros de diversas áreas do conhecimento relativos ao estudo dos povos de língua bantu.

O primeiro editorial do Nsi indica a sua vinculação ao CICIBA:

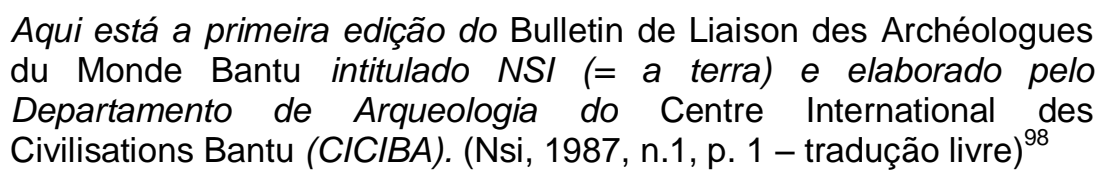

Como vimos, o título do boletim Nsi foi traduzido por Obenga como "a terra" ["la terre"]. Segundo Watkins (1937, p.139), o termo "nsi" no vocabulário bantu significa "chão" ["ground", em inglês] e aparece em outras línguas africanas, como, por exemplo, o Swahili, nas grafias "nci", "ntci" e "nchi" significando "terra" ["land" e "earth", em inglês].

Pode-se ver que "nsi" é uma palavra que alude o lugar onde residem ou vivem os homens, em micro escala, num plano doméstico, como: piso, chão, terreiro, território, planeta e mundo; e, num plano universal ou mesmo cósmico, em macro escala.

Obtivemos acesso às capas do boletim Nsi somente em reproduções de baixa resolução visualizadas como miniaturas nos endereços eletrônicos do diretório de publicações arqueológicas AFRICAN-ARCHAEOLOGY NET (a) e do GOOGLE BOOKS (ver figura dezoito).

\footnotetext{
${ }^{98}$ Voici la première livraison du Bulletin de Liaison des Archéologues du monde Bantu intitulé NSI ( = la terre) et préparé par le Département d'Archéologie du Centre International des Civilisations Bantu (CICIBA). (Nsi, $n^{\circ} 1,1987$, p. 1)
} 
A logomarca deste boletim apresenta uma pequena ilustração, na parte superior à esquerda, das presas de elefante que rementem ao pórtico do edifício-sede do CICIBA (ver figura dezenove). Na edição dupla oito-nove de 1991 houve uma mudança na representação icônica adotando-se como ilustração da capa a fachada completa do edifício. As capas das primeiras edições, de um a sete, apresentam, também, como ilustração, um pote globular parcialmente decorado pelo desenhista, em tamanho maior do que as presas de elefante.

As capas das edições oito-nove e dez-onze contêm, além da fachada do edifício do CICIBA, três potes de diferentes formatos: um pote para água, uma tigela e uma panela, parcialmente decorados.

Para dar a conhecer visualmente o corpus de nossa pesquisa, agora, no caso do Nsi, reproduzimos uma capa, um trecho de editorial, dois detalhes das ilustrações e o pórtico do edifício-sede, atualmente em processo de restauração (CICIBA.NET a, 2012). O CICIBA retomou as suas atividades em Libreville, sob o interesse de Ali Bongo Ondimba, filho de Omar Bongo e seu sucessor como presidente do Gabão. A instituição pode ser conhecida pelo endereço eletrônico CICIBA.NET b.

\section{Figura 18 - Reprodução da capa e do trecho de um editorial do Nsi}

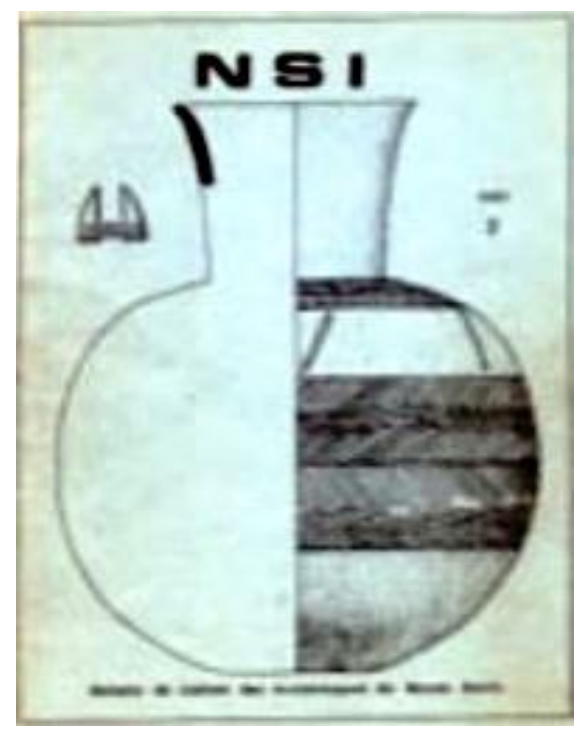

Fonte: AFRICAN-ARCHAEOLOGY.NET b, Nsi, 1987, n.2.

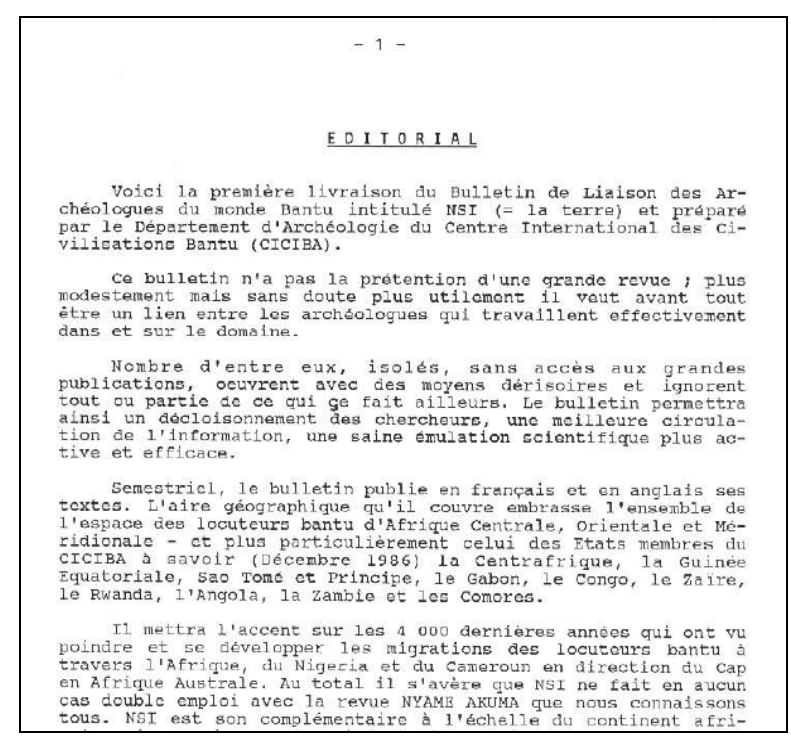

Fonte: AFRICAN-ARCHAEOLOGY.NET c, Nsi, 1987, n.1, p.01. 


\section{Figura 19 - Detalhe das presas de elefante presentes nas capas do Nsi e na fachada do CICIBA}

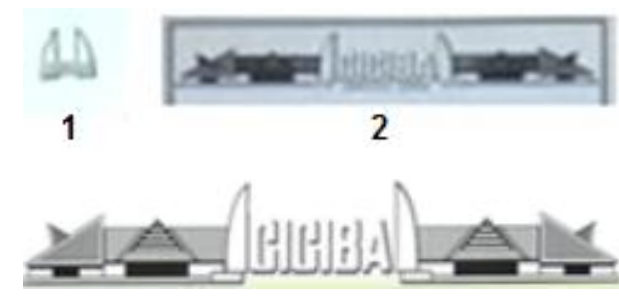

3

1.Detalhe da capa do Nsi, 1987, n.2

2.Detalhe da capa do Nsi, 1991, n.8-9

(AFRICAN-ARCHAEOLOGY.NET a)

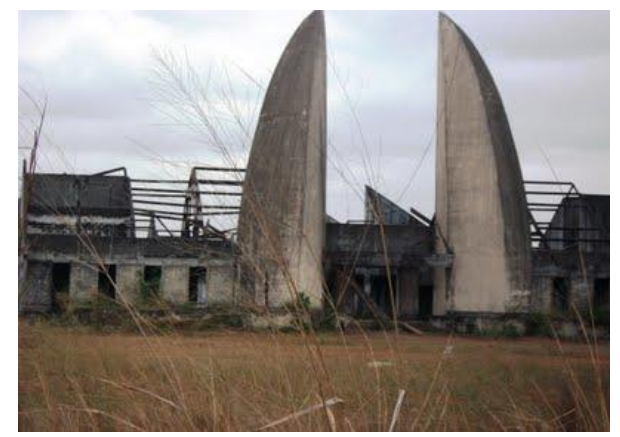

Fachada do edifício-sede abandonado do CICIBA. (GABONECO, 26/09/2011, acesso em $15 / 12 / 2012)$

3. Detalhe da logomarca do site

CICIBA.NET b, acesso em 15/12/2012.

São poucos os documentos que analisam a curta existência do boletim Nsi. Conforme o texto de apresentação do seu atual endereço eletrônico AFRICAN-ARCHAEOLOGY.NET a, que o disponibiliza para consulta e download gratuito das edições, a publicação deixou de circular em 1993, devido ao "desinteresse" do CICIBA que o publicava". A partir desse ano, o Nsi foi incorporado ao boletim Nyame Akuma na edição de junho de 1993, número 39. O texto abaixo foi retirado desse endereço eletrônico:

Lançado em 1987 foi o único meio de comunicação para os arqueólogos da zona linguística bantu, e, mais especificamente, para os arqueólogos que trabalhavam na África Central. Nsi foi uma publicacão adicional necessária para o boletim Nyame Akuma, de envergadura continental, meio de comunicação da sociedade dos arqueólogos africanistas. (AFRICAN-ARCHAEOLOGY.NET a, acesso em 20/11/2012, - tradução livre, grifos nossos) ${ }^{100}$

\footnotetext{
${ }^{99}$ [L]e bulletin $N s i$ directement associé au travail des deux éditeurs fut arrêté en 1993 face au désintérêt de l'organisation hôte. (AFRICAN-ARCHAEOLOGY.NET a, acesso em 20/11/2012 - grifos nossos)

${ }^{100}$ Lancé en 1987 ( $\left.{ }^{\circ} 1\right)$, ce bulletin de liaison Nsi (= "la terre") sera le seul organe de communication des archéologues spécialisés sur la zone linguistique bantu et plus particulièrement pour les archéologues travaillant en Afrique centrale. Ce bulletin était un complément indispensable à la revue Nyame Akuma d'envergure continentale, organe de la société des archéologues africanistes. (AFRICANARCHAEOLOGY.NET a, acesso em 20/11/2012)
} 
Perante essas referências, percebe-se que o Nsi é apresentado como uma publicação "suplementar" ao boletim Nyame Akuma, veiculando a ideia dele ser um boletim "menor" comparado à "cobertura elástica" de "envergadura continental" do NA. Em seu editorial do ano de 1987, de número um, escrito por Obenga, há o seguinte enunciado:

[O] Nsi de forma alguma duplica [sobrepõe-se] a revista Nyame Akuma que todos nós conhecemos. Nsi é a sua complementar no continente africano, mas, também, uma necessidade absolutamente inevitável para a região [do CICIBA]. (Nsi, 1987, n.1, p.1 - tradução livre, grifos do autor $)^{101}$

Nesse trecho do editorial de Obenga, nota-se que o boletim Nsi é também foi tido pelo diretor do CICIBA como uma publicação "complementar" do boletim NA. Enquanto este possui uma cobertura geográfica e temporal mais "elástica", aquele, o Nsi, debruça-se especificamente sobre o estudo dos povos de língua bantu na região do CICIBA.

Phillipson (1988), que redigiu uma resenha sobre o primeiro número do boletim, apontou algumas "omissões" da publicação. Segundo o autor, contemplaram-se as notícias sobre a bibliografia e as pesquisas arqueológicas no noroeste da zona bantu - Gabão e a atual República Popular do CongoBrazzaville, dando pouco destaque àquelas dos outros países-membros do CICIBA, como: República Centro-Africana, Guiné Equatorial, São Tomé e Príncipe, Zaire, Ruanda, Zâmbia, Angola e Comores.

A edição e a publicação do Nsi foram dependentes do patrocínio dos países-membros do CICIBA, relembrando: República Centro-Africana, Guiné Equatorial, São Tomé e Príncipe, Gabão, Congo - Brazzaville (República do Congo), Zaire (RDC ou Congo - Kinshasa), Ruanda, Angola, Zâmbia e Comores. Foi fato que, no ano de 1990, esses Estados disponibilizariam 3.000,00 francs CFA para a produção e distribuição do boletim. Esse patrocínio financiava o envio gratuito da publicação às instituições museológicas e centros de pesquisa arqueológica africana (CLIST e LANFRANCHI,1989).

\footnotetext{
${ }^{101}$ Au total il s'avère que Nsi ne fait en aucun cas double emploi avec la revue Nyame Akuma que nous connaissons tous. Nsi est son complémentaire à l'échelle du continent africain mais aussi une nécessité absolument incontournable pour la sous-région. (Nsi, 1987, n.1, p.1)
} 
Na década de 1980, circularam outras revistas arqueológicas de âmbito regional na África Central além do Nsi: Annales des Facultés des Lettres et Sciences Humaines de Youndé (Gabão, 1969); Revue Gabonaise des Sciences de l'Homme (Gabão, 1988); Cahiers Congolais d' Anthropologie et d'Historie (Congo - Brazzaville, 1976); Annales Aequatoria (Zaire, s.d); Afrika Zamani (Camarões, s.d); Études Rwandaises (Ruanda, 1986); e, The Livingstone Museum Newsletter (Zâmbia, s.d.). Estas, não localizadas em nossa pesquisa, eram caracterizadas pela periodicidade irregular, segundo Clist e Lanfranchi (1989).

A ideia de criar o Centre International des Civilisations Bantu foi expressa em julho de 1982 por El Hadj Omar Bongo, ditador do Gabão, durante sua palestra inaugural da Primeira Conferência dos Ministros da Cultura da Zona Bantu (MBOT, 1991, p.07). Em 08 de janeiro de 1983, os ministros da cultura representantes de Angola, República Centro-africana, Comores, Congo - Brazzaville, Gabão, Guiné Equatorial, Ruanda, São Tomé e Príncipe e Zâmbia assinaram a convenção que instituiu a organização.

Essa foi uma iniciativa de caráter internacional, visto que congregou países da África Central e Austral. Insere-se nas perspectivas pan-africana e afrocentrista da década de 1980 , que retomam a temática de valorização dos fundamentos da identidade negro-africana, especificamente, a Bantu, em pauta nas lutas pelas independências. Desde a geração dos intelectuais africanos de 1956, as áreas de História e Arqueologia africanista e africana vivenciaram uma revolução irradiada de dentro do continente pela abordagem militante da África autodeterminada. Segundo M'Bokolo (2011):

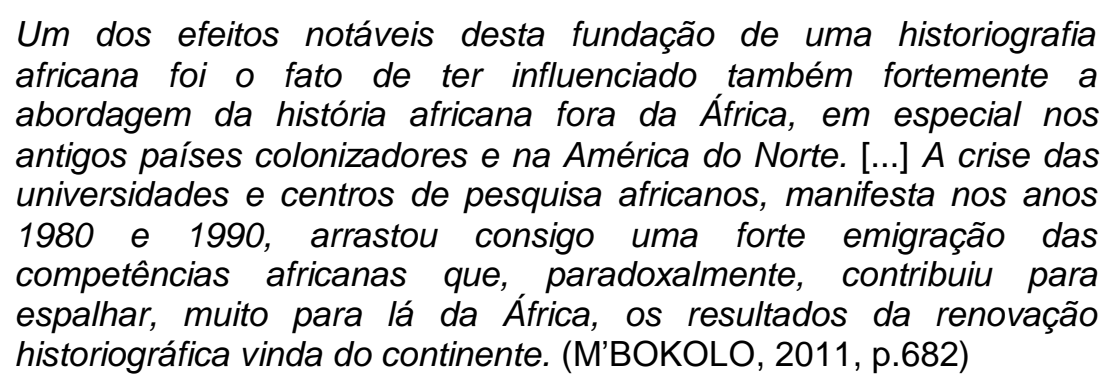

$\mathrm{Na}$ África Ocidental, Kwame Nkrumah (1909-1972), profundamente imbuído e disseminador das ideias pan-africanas e da luta pela independência da antiga Costa do Ouro, hoje Gana, influenciou parcelas das elites intelectuais 
de outras colônias africanas. Esse é o caso de Patrice Lumumba (1925-1961) do Congo Belga - atual RDC, que tal qual Nkrumah, participou do processo de libertação e da posterior organização política independente do seu país.

Os intelectuais africanos formaram um conjunto de forças que contribuíram para a aceleração das lutas de independência e a consolidação dos novos Estados africanos em clima de nacionalismo (M'BOKOLO, 2011, p.577, 588). Esses estudiosos, tendo formação universitária nos Estados Unidos, na França, no Reino Unido, entre outros países conhecedores das literaturas coloniais sobre a África, assumiram posição combativa na construção do conhecimento científico no que se refere à escolha dos temas e das abordagens. Todavia, se chocaram com a dificuldade de divulgação dos conteúdos das suas novas propostas de análise.

O CICIBA, que publicou o boletim $N s i$, originou-se nesse contexto de produção pan-africana de conhecimento científico sobre a África, tendo "como missão principal promover o patrimônio cultural comum à África e de se colocar a serviço do desenvolvimento"102 (MBOT, 1991, p.08 - tradução livre). A ideia de fomento do desenvolvimento do continente, antítese da ideia de crise estrutural, é relacionada ao resgate dos valores culturais das civilizações de língua bantu, como podemos constatar no trecho a seguir de Mbot (1991) que, no ano de 1985, era o Ministro da Cultura do Gabão e Presidente do Conselho de Administração do CICIBA:

Esta opção [de promover o patrimônio cultural comum] permitirá à África garantir plenamente a sua identidade cultural, restaurar cientificamente a unidade dos seus povos e reuni-los dentro da mesma comunidade cultural. (MBOT, 1991, p.08 - tradução livre) ${ }^{103}$

A estratégia para cumprir essa missão compunha-se de três planos de ação (MBOT, 1991, p.11):

i) Elaboração de um banco de dados;

ii) Pesquisa científica; e,

\footnotetext{
102 [...] le CICIBA a pour mission principale de promouvoir le patrimoine culturel commun à la Afrique et de le mettre au service du développement. (MBOT, 1991, p.08)

103 Cet option permettra à l'Afrique d'assurer pleinement son identité culturelle, de rétablir scientifiquement l'unité de ses peuples et de les rassembler au sein d'une même communauté culturelle. (MBOT, 1991, p.08)
} 
iii) Produção cultural nas áreas da arqueologia, da linguística e das tradições orais.

O projeto de criação de dois bancos de dados na área da arqueologia foi apresentado no primeiro editorial do Nsi, escrito por Obenga, datado de 1987, os quais seriam compostos de:

Um arquivo bibliográfico exaustivo ("CIBARCHEO") irá gerir os fundos documentários [do Centro de Documentação do CICIBA e] um arquivo informatizado em constituição ("CIBADATE") irá gerir a base de dados. (Nsi, 1987, n.2, p.3 - tradução livre) ${ }^{104}$

O CIBARCHEO e o CIBADATE inserem-se entre os oito objetivos da convenção que instituiu o CICIBA, cuja finalidade seria "constituir um banco de dados e um centro de documentação sobre as culturas e civilizações dos povos de línguas bantu" (MBOT, 1991, p.10 - tradução livre) ${ }^{105}$.

Consideramos que a publicação do boletim Nsi foi o resultado do desejo dos chefes de Estado, como por exemplo, o ditador Omar Bongo, de financiar, por meio de uma instituição científica, um veículo divulgador das ideias sobre uma unidade fundamental dos povos de língua bantu. A cooperação científica dos Estados africanos, signatários do CICIBA, visava reconstituir a história desses povos e "dar-lhes" consciência da sua identidade cultural, criatividade e independência. Mbot (1991, p.08) define o CICIBA recorrendo a uma imagem digna de nota, como a "enciclopédia", no seu sentido etimológico, de 150 milhões de bantu da África e da diáspora ${ }^{106}$. Em outras palavras, o boletim Nsi, constituiu nessa formulação, o meio de propagação dos estudos de diversas áreas do conhecimento sobre a herança ancestral dos milhões de descendentes de povos de língua bantu pelo mundo.

O período histórico de criação do boletim Nsi aconteceu no último quarto do século $X X$, quando o processo de independência dos países da África

\footnotetext{
${ }^{104}$ Un fichier bibliographique informatisé exhaustif (“CIBARCHEO”) gérera ce fonds documentaire. [...] Là aussi un fichier informatisé en voie de constituition ("CIBADATE") gérera la base de données. (Nsi, 1987, n.2, p.3)

${ }^{105}$ [C]onstituer une banque de données et un centre de documentation sur les cultures et civilisations des peuples de langues bantu. (MBOT, 1991, p.10)

106 [...] le CICIBA constitue, en quelque sorte l'Encyclopédie des 150 millions des Bantu d'Afrique ainsi que ceux de la diaspora. (MBOT, 1991, p.08)
} 
Central estava envolto na atmosfera das hegemonias metropolitanas. Essas ideias e forças contraditórias são verificadas no contexto de formação do CICIBA, em 1983, e da publicação do Nsi, em 1987. Esse centro de estudos, fruto de uma política cultural fomentada pelos Estados africanos francófonos, numa perspectiva pan-africana, era sediado no Gabão, país governado, desde 1967, pelo ditador Omar Bongo.

Os temas do pan-africanismo, como a união dos povos, foram retomados por Bongo, na iminência do centésimo aniversário da Conferência de Berlim (1884-85). A ideia de criar um instituto dos povos negros também foi lançada pelo capitão Thomas Sankara, dirigente do Burkina Faso, entre os anos de 1983 e 1987. A criação do CICIBA, portanto, emerge desse contexto de reelaboração da ideologia pan-africana. Segundo M'Bokolo (2011):

De fato, só à escala regional, sob o impulso do Gabão, a maioria dos
Estados da África Central resolveu criar em 1980 [sic, 1983] um
Centro Internacional das Civilizações Bantas (CICIBA), encarregado
de estudar, dar a conhecer e promover as civilizações e as indústrias
culturais dessa região. [...] Apesar desta letargia, é de assinalar que,
nos anos 1980 e 1990, se assistiu na África a um ressurgimento da
análise pan-africana e voluntarista das políticas culturais elaboradas
pelos Estados [...] (M'BOKOLO, 2011, p.678)

O cumprimento das funções do CICIBA e do Nsi dependia da injeção de recursos financeiros através do financiamento governamental dos seus paísesmembros, como já indicado anteriormente. Para Pavan (1988), o modelo europeu de amparo governamental às pesquisas científicas implica em uma dependência exclusiva do poder público, fato verificado na situação do boletim Nsi em relação ao governo gabonês do ditador Omar Bongo. Essa dependência estatal pode ser uma das causas do envolvimento do CICIBA nas situações econômicas locais e do seu progressivo desmonte no Gabão, acarretando na interrupção da produção do boletim Nsi.

\section{Os editoriais e os editores}

Théophile Obenga, responsável pela "direction génerale du CICIBA", que assina o primeiro editorial do Nsi, em 1987, afirma: 
pesquisadores, um melhor fluxo da informação [...] (Nsi, 1987, n.1, p.1 - tradução livre, grifos nossos) ${ }^{10}$

A comunicação entre os arqueólogos da região abrangida pelo CICIBA foi uma demanda que mobilizou a criação do boletim. O editorial reporta 0 isolamento como a característica imagética dos arqueólogos africanos e africanistas que trabalharam na região até aquele ano de 1987. Essa imagem de isolamento era especificada como "sem acesso às publicações importantes, que trabalham com meios exíguos e não sabem nada ou sabem alguma coisa do que está sendo feito em outros lugares" (Nsi, 1987, n.1, p.1 - tradução livre $)^{108}$. Nessa perspectiva, o boletim Nsi foi criado com a função de informar os arqueólogos, antes isolados devido a inexistência ou precaridade dos meios de comunicação e transportes entre os sítios arqueológicos e as cidades e, também, o baixo financiamento das pesquisas (cf. ROBERTSHAW, 1994).

As palavras que denotam exiguidade, empregadas no enunciado descatado anteriormente - "sem", "escassos", "não" e "nada", reforçam a imagem do arqueólogo considerado "ideal", com meios de trabalho e informação. O editor Obenga, partindo dessa noção de exiguidade, apresenta no editorial da edição número dois, do ano de 1987, a vantagem desses arqueólogos que trabalhavam na região: o Nsi, naquela edição, oportunizou a um maior número de africanos a publicação das suas pesquisas. Entre os autores, "nove eram africanos", um era japonês, dois eram americanos e quatro eram europeus.

No número seguinte, em 1988, outro destaque foi dado com a seguinte justificativa para a escolha editorial:

Os dezesseis pesquisadores que colaboraram nessa primeira edição de 1988 são todos residentes no continente africano, mais capazes de compreender as realidades cotidianas da região. Duas exceções

\footnotetext{
${ }^{107}$ Il veut avant tout être un lien entre lês archéologues qui travaillent effectivement dans et sur le domaine. [...] Le bulletin permettra ainsi un décloisonnement des chercheurs, une meilleure circulation de l'information [...] (Nsi, 1987, n.1, p.1)

${ }^{108}[\ldots]$ sans accès aux grandes publications, oeuvrent avec des moyens dérisoires et ignorent tout ou partie de ce qui çe fait ailleurs. (Nsi, 1987, n.1, p.1)
} 
são James Denbow e Bernard Farine. (Nsi, 1988, n.3, p.3 - tradução livre - grifos nossos) ${ }^{109}$

Os arqueólogos habitantes do continente africano que publicaram na edição de 1988 são elencados, no sumário da publicação, com os respectivos locais de pesquisa: L. Pais Pinto (Angola); J.M. Essomba (Camarões); J. Moga (República Centro-Africana); R. Lanfranchi e B. Pinçon (República Popular do Congo); A. Manima e N. Sanviti (Brazzaville); B. Clist, L. Digombe, M. Locko, P.J. Jézégou, R. Oslisly e B. Peyrot (Gabão); e, Y.M. Jumayeyi (Malawi).

Nesses três primeiros editoriais, o número um foi escrito por Obenga e os números dois e três assinados por Ba-Meya. Elencamos o uso de certos enunciados para identificar os arqueólogos mais qualificados para tratar da arqueologia da África Central:

\section{Imagem 1}

Enunciado identificador (local de trabalho): "arqueólogos que trabalham efetivamente na e sobre a região" (Nsi, 1987, n.1, p.1).

\section{Imagem 2}

Enunciado identificador (local de nascimento): "nove são africanos" (Nsi, 1987, n.2, p.3).

\section{Imagem 3}

Enunciado identificador (local de residência): "são todos residentes no continente africano, mais capazes de compreender as realidades cotidianas da região" (Nsi, 1988, n.3, p.3).

O destaque dado à localidade de estabelecimento do arqueólogo-autor e pelo enunciado - "residentes no continente africano, mais capazes de compreender as realidades" - se tornou um dos atributos da imagem ideal do arqueólogo veiculado pelos editoriais para produzir e divulgar conhecimento sobre a África. É importante destacar que essa ideia não é explicitada nos editoriais dos boletins TSAAB e NA, publicados, respectivamente, pela SAAS e pela SAfA. Segundo Shepherd (2002) e Ndlovu (2005), que tratam da arqueologia da África Austral, vivenciar a realidade das populações nativas

\footnotetext{
${ }^{109}$ Les seize scientifiques qui ont collaborés à ce premier numéro de l'année 1988 sont touts résidents sur le continent africain, mieux à même de cerner les réalites quotidiennes de la sous-régions. Deux exceptions, James Denbow et Bernard Farine. (Nsi, 1988, n.3, p.3)
} 
africanas na sua relação cotidiana com o patrimônio arqueológico é uma das críticas pós-processualistas àqueles arqueólogos que discutem a arqueologia distanciadamente a partir dos seus gabinetes.

Um atributo da imagem ideal do arqueólogo africano e africanista relaciona-se a uma agenda de mobilização dos especialistas africanos, elencada por Bagodo (2004). Nesse raciocínio, devem contar com o apoio das instituições locais, como o CICIBA, apropriando-se de estruturas como museus, universidades, sociedades e instituições de pesquisa para promover a reestruturação das práticas arqueológicas.

Uma das ações dessa agenda de mobilização, como notado na proposta editorial do Nsi, seria localizar os pesquisadores e divulgar o conhecimento endógeno produzido por africanos, visando superar as sequelas do colonialismo e do racismo na disciplina arqueológica. Como um exemplo dessas sequelas, Robertshaw (1990) aponta que uma peculiaridade nos estudos arqueológicos sobre a África se deve ao fato que as teorias, os métodos, os conceitos e os objetivos surgem nas "regiões metropolitanas" para fundamentar as pesquisas em regiões, como a África Central. Hountondji (1995) retoma, como mobilização dos intelectuais africanos, a imediata apropriação da herança científica internacional com mente crítica e a reapropriação do legado intelectual dos ancestrais criando, a partir daí, novas metodologias e perspectivas teóricas africanas.

Segundo Hountondji (1995, p.02), a principal orientação a ser combatida é a extroversão das atividades científicas desenvolvidas na África. Essa orientação para o "exterior" implica na subordinação do conhecimento tradicional e endógeno ao sistema mundial de produção, fenômeno similar ao verificado na dependência das economias de subsistência africanas ao sistema capitalista. Nessa perspectiva, a construção e divulgação do saber arqueológico pelos arqueólogos residentes no continente, principalmente os africanos, como apontado pelos três enunciados transcritos no quadro acima, integra uma agenda de ações que se desvencilha de uma tradição intelectual e de um projeto colonial de apropriação e controle do conhecimento pelo Ocidente. 
Como comprovação dessa agenda de ações, Clist e Lanfranchi (1989) divulgam uma tabela com a distribuição das revistas que tratam de Arqueologia da África nas instituições dos estados-membros do CICIBA (vide tabela abaixo). Nela, observa-se a diferença na distribuição dos boletins Nsi, Nyame Akuma e The South African Archaeological Bulletin nas instituições científicas relacionadas na legenda. Ambos os editores destacam o diferencial da publicação, $N s i$, localizada na décima-terceira linha, que se apresenta em todas as instituições da região numeradas e marcadas com um "X". Essa tabela, na nossa interpretação, indicaria a maior visibilidade dos autores que publicam no Nsi consequente da maior dispersão de um boletim pertencente a uma agenda de ações para a construção e divulgação do conhecimento por residentes no continente africano (cf.VICTORA e MOREIRA, 2006; MENEGHINI e PACKER, 2007).

O boletim Nyame Akuma, transcrito na terceira linha da tabela abaixo, abaixo reproduzida, aparece em cinco das nove instituições relacionadas: CICIBA (Gabão), Museu Nacional de Arqueologia (Angola), Projet Paléogab (Gabão), Musée de Lubumbashi (Zaire) e Musée de Livingstone (Zâmbia), denotando uma distribuição entre os estados-membros de língua inglesa, francesa e portuguesa. O boletim The South African Archaeological Bulletin, na quarta linha, apresenta-se em duas instituições: o próprio CICIBA e o Musée de Livingstone. Isso aponta para a especialização da cobertura do TSAAB na África Austral de língua inglesa, apesar de a sua cobertura geográfica partir "da África Central ao Cabo", como já abordado no capítulo quatro, e o boicote científico das instituições africanas contra o regime segregacionista.

Figura 20 - Reprodução da "Tabela de difusão dos periódicos de arqueologia africana nos estados-membros" 
Légende: 1= CrcrBA, 2=Musée National d'Archéologie d'Angola, 3= Centre de Documentation Comores, $4=$ Laboratoire d'Anthropologie Congo, 5= Laboratoire universitaire Gabon, $6=$ Projet Paléogab Gabon, 7= Musée de Lubumbashi Zaïre, 8- Musée de Kinshasa Zaïre, 9= Musée de Livingstone Zambie.

\begin{tabular}{|c|c|c|c|c|c|c|c|c|c|}
\hline Revues & 1 & 2 & 3 & 4 & 5 & 6 & 7 & 8 & 9 \\
\hline Afr.Arch. Rev. & $\mathrm{x}$ & - & - & - & - & - & - & - & $x$ \\
\hline Azania & $x$ & - & $x$ & - & - & - & $x$ & - & $x$ \\
\hline Nyame Akuma. & $x$ & $\mathrm{x}$ & - & - & - & $\mathbf{x}$ & $\mathbf{x}$ & - & $x$ \\
\hline South afr.arch.bull. & $\mathbf{x}$ & - & - & - & - & - & - & - & $\mathrm{x}$ \\
\hline Cah. cong. d'anth.et d'hist. & $\mathrm{x}$ & - & - & $x$ & - & $x$ & - & - & - \\
\hline Afrika Zamani & $\mathrm{x}$ & - & - & $x$ & - & - & - & - & - \\
\hline West afr.arch.journ. of Arch & $\mathbf{x}$ & - & - & - & - & - & - & - & - \\
\hline L'Anthropologie & $x$ & - & $\mathrm{x}$ & - & - & $\mathrm{x}$ & - & - & - \\
\hline World Arch. & $x$ & - & - & - & - & - & - & - & - \\
\hline Journ. of Arch.Science & $\mathrm{x}$ & - & - & - & - & - & - & - & - \\
\hline Archaeometry & $\mathrm{x}$ & - & - & - & - & - & - & - & - \\
\hline Radiocarbon & $\mathrm{x}$ & - & - & - & - & - & - & - & - \\
\hline Ns $i$ & $\mathbf{x}$ & $\mathrm{x}$ & $x$ & $\mathbf{x}$ & $x$ & $\mathrm{x}$ & $x$ & $\mathrm{x}$ & $\mathrm{x}$ \\
\hline Muntu & $\mathrm{x}$ & - & $\mathrm{x}$ & $x$ & - & - & $\mathrm{x}$ & - & - \\
\hline Taloha & - & - & $\mathrm{x}$ & - & - & - & - & - & - \\
\hline Etudes del'Océan Indien & - & - & $x$ & - & - & - & - & - & - \\
\hline
\end{tabular}

Fonte: CLIST e LANFRANCHI (1989, p.148)

Já, os boletins NA e TSAAB, nessa amostragem com nove instituições relacionadas, possuem uma menor penetração na região de cobertura do CICIBA ao compararmos com a estatística do Nsi, este presente em nove instituições cientificas. A explicação para essa situação pode estar associada às línguas das publicações: anglófonas - TSAAB e Nyame Akuma - e francófona - Nsi.

Em editorial de 1987, na edição de número dois, Obenga escreve sobre a publicação dos relatórios sobre Botsuana, Namíbia, Zâmbia e Zimbábue:

Enquanto a primeira edição enfatizou a área francófona, uma abertura para os estados africanos anglófonos é realizada [nessa edição] [....] (Nsi, 1987, n.2, p.1 - tradução livre, grifos nossos) ${ }^{110}$

Se no primeiro editorial do Nsi, datado de 1987, houve a afirmação da cobertura geográfica do boletim na República Centro-Africana, na Guiné Equatorial, em São Tomé e Príncipe, no Gabão, em Congo-Brazzaville, no Zaire (RDC), em Ruanda, em Angola, na Zâmbia e em Comores, como um ato

\footnotetext{
${ }^{110}$ Alors que le premier bulletin mettait plutôt l'accent sur le domaine francophone, une ouverture en direction des états africains anglophone se concrétise [...] (Nsi, 1987, n.2, p.1)
} 
de fundação do lançamento da publicação, no segundo, divulgado no mesmo ano, explicitou-se a intenção do editor, diretor de pesquisa do CICIBA, em ampliar os contatos entre arqueólogos francófonos e anglófonos residentes na região. Em editorial do ano de 1989, Clist e Lanfranchi, escrevem:

Se o boletim cumpre bem o seu papel nos estados-membros francófonos e lusófonos, devemos admitir que nossos colegas anglófonos ainda não estão convencidos do valor do NSI. (Nsi, 1989, n.5, p.3 - tradução livre, grifos nossos) ${ }^{111}$

Nessa perspectiva, os editores responsabilizam os arqueólogos anglófonos pela dificuldade do boletim Nsi em não cumprir completamente a sua função - a de interação entre os especialistas da área bantu. Afinal, os arqueólogos anglófonos ainda não haviam compreendido a importância delegada ao Nsi de estabelecer o contato entre os arqueólogos da África central e, provavelmente, preferir publicar em outra publicação em língua inglesa, de "orientação externa", como, por exemplo, o Nyame Akuma.

O Nsi - Bulletin de Liaison des Archéologues du Monde Bantu, como o próprio título indica, visava estabelecer a ligação, ou mais precisamente, "unir" os arqueólogos residentes na África subsaariana, em torno dos estudos da identidade dos povos de línguas bantu. Essa ideia associa-se à perspectiva pan-africana das autoridades dos estados-membros do CICIBA, conforme apontado por Tourneux (1983) e Mbot (1991). O diretor da instituição, Obenga, que escreveu o primeiro editorial, deve ser destacado nessa análise.

O congolês, nascido em Brazzaville, Théophile Obenga, diretor do CICIBA, redigiu o editorial da edição de número um do ano de 1987. Esse editorial tive como palavra-chave principal "a organização do boletim" e como palavras-chave secundária às informações sobre o "lançamento" dessa publicação. Obenga, expoente do Afrocentrismo (GRAHAM, 1999, p.257), foi discípulo de Cheikh Anta Diop e aproximou-se muito das suas teorias que concebem a África como berço das civilizações. Assim como Diop, a sua área

\footnotetext{
${ }^{111} \mathrm{Si}$ le bulletin rempli bien son rôle dans Etats-Membres Francophones et Lusophones, il faut bien avouer que nous collègues Anglophones ne sont pas encore convaincus de l'intérêt de NSI. (Nsi, 1989, n.5, p.3)
} 
de interesse é Egiptologia, uma área fora da cobertura geográfica do boletim Nsi (FARIAS, 2003).

Figura 21 - Cheikh Anta Diop, à esquerda e Théophile Obenga, à direita (1981).

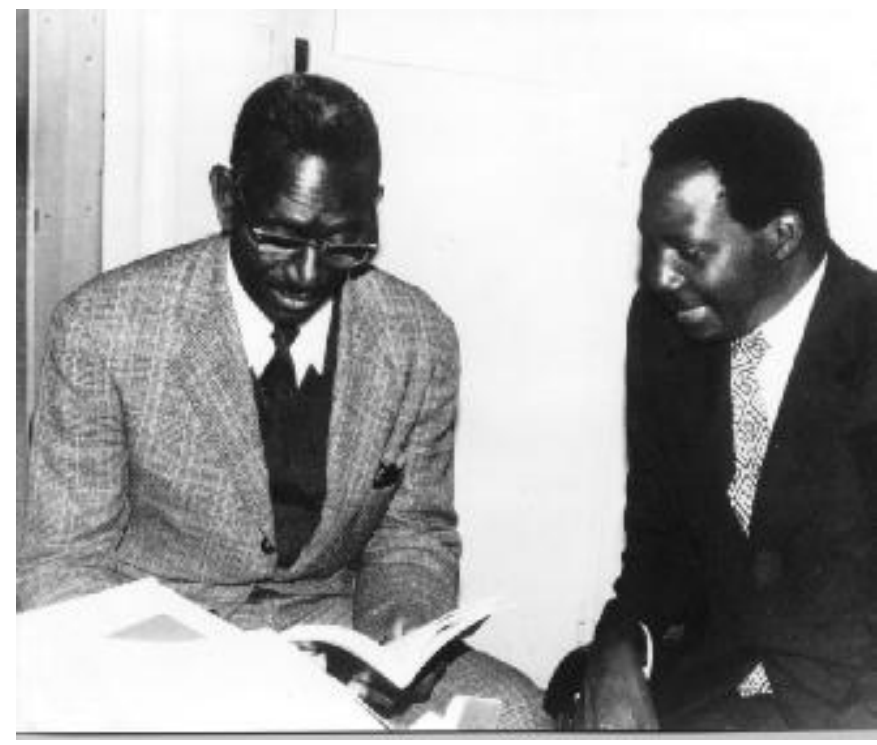

Fonte: REVUE ANKH, acesso em 20/11/2012.

Obenga foi diretor geral do CICIBA até o ano de 1991. Editou a Revue Ankh, especializada em egiptologia, entre os anos de 1992 e 2008 (REVUE ANKH, acesso em 20/11/2012). Atualmente, é professor emérito da San Francisco State University (SAN FRANCISCO STATE UNIVERSITY, acesso em 16/12/2012).

O diretor da pesquisa Bayona-Ba-Meya foi, em 1973, decano da Faculdade de Direito, campus Kinshasa, da Université Nationale du Zaïre (Nsi, 1989, n.6, p.178; AFRICA, 1973, p.154). Teve uma produção bibliográfica, nas décadas de 1970 e 1980, na área jurídica publicada na forma de artigos científicos em revistas locais, como a Revue juridique du Zaïre: droit écrit et droit coutumier e regionais, como a Muntu: Revue scientifique et culturelle du CICIBA, a Penant: Revue de droit des pays d'Afrique e a Revue juridique et politique: indépendance et coopération (AFRICABIB, acesso em 16/12/2012). Segundo Wicks (2000, p.294) e MacGaffey (1982, p.93), ba-Meya foi Presidente da Suprema Corte do Zaire. Posteriormente, em meados dos anos 1990, teve ainda uma atuação política nas palavras de Metz (1996, p.19), como 
Presidente da Comissão Eleitoral do Zaire, foi "Mobutu loyalist" [leal ao ditador Mobutu].

A imagem dos arqueólogos anglófonos como desinteressados, veiculada pelos editoriais de 1987 (n.2), 1988 (n.5) e 1991 (n.8-9), foi contraposta a duas situações apresentadas nos editoriais de 1991 e 1992 escritos por Clist:

\section{Situação 1}

O desinteresse dos demais arqueólogos (francófonos e lusófonos) em enviar os relatórios para publicação, expresso nos enunciados:

Enunciado identificador: "A ausência de resposta dos arqueólogos estabelecidos nos estados-membros do CICIBA que parecem pouco inclinados em participar ativamente com informações para o Nsi e, portanto, para a rede [dos arqueólogos]." (Nsi, 1991, n.8-9, p.3 - tradução livre)

Enunciado identificador: "A ausência de correspondentes [...] só depende de vocês [...]" (Nsi, 1992, n.10-11, p.3 - tradução livre, grifo do autor). ${ }^{113}$

\section{Situação 2}

A rigidez do CICIBA em admitir relatórios oriundos dos países anglófonos, identificado nos enunciados:

Enunciado identificador: "[...] uma débil abertura do Nsi para o mundo africano anglófono (África Oriental e Austral). 1992 deve ser o ano dessa abertura: nós a esperamos e estamos trabalhando para isso." (Nsi, 1991, n.8-9, p.3 - tradução livre) ${ }^{114}$

Enunciado identificador: "[A abertura] depende do Departamento de Arqueologia e do Museu do CICIBA: esta falta de abertura está sendo resolvida, talvez para o número 11..." [sic, 12] (Nsi, 1992, n.10-11, p.3 - tradução livre) ${ }^{115}$

Notamos que, nos editoriais do Nsi, entre os anos de 1987 e de 1992, houve uma recorrência na formulação da imagem desinteressada dos arqueólogos dos países de língua inglesa. Segundo os editores, era um desinteresse pela constituição de uma rede de informação arqueológica. Essa

\footnotetext{
${ }^{112}$ Le manque de répondant des archéologues en poste dans les Etats-Membres du CICIBA qui nous semblent peu enclin à participer activement à l'information dans Nsi et donc au réseau. (Nsi, 1991, n.8-9, p.3)

${ }^{113}$ Le manque de répondants [...] ne dépend que de VOUS [...] (Nsi, 1992, n.10-11, p.3)

114 [...] une faible ouverture de Nsi sur le monde africain anglophone (Afrique Orientale et Australe). 1992 doit être l'année de cette ouverture: nous l'espérons et nous y oeuvrons. (Nsi, 1991, n.8-9, p.3)

115 [...] dépend du Département d'Archéologie et du Musée du CICIBA: ce manque d'ouverture est en voie de résolution, peut être que pour le número 11... (Nsi, 1992, n.10-11, p.3)
} 
rede em formação era tida pelos editores como uma solução para a situação de isolamento dos arqueólogos estabelecidos nos estados-membros do CICIBA. A baixa adesão dos arqueólogos de língua inglesa em enviar as notícias das suas pesquisas, participando assim, desse circuito proporcionado pelo Nsi, pode estar associada à preferência dos arqueólogos pelas publicações anglófonas, de "orientação externa", consolidadas e citadas pelos pares da comunidade arqueológica, como é o caso do Nyame Akuma, entre outras.

A imagem tida como referência para os arqueólogos, veiculada nos editoriais assinados por Obenga, Ba-Meya, Clist e Lanfranchi, agrega-se às ideias pan-africanas acerca do conceito de união e solidariedade.

Notamos que a própria presença dos editores franceses Clist e Lanfranchi indica que noção de rede de especialistas, por parte do conselho editorial, extrapola o âmbito da discussão que coloca em oposição às imagens de africanos e africanistas e apresenta a ideia de cooperação (cf. BAGODO, 2004). Essa ideia de trabalho coletivo dos especialistas, em cooperação, foi indicado no documento datado de 12 de setembro de 1986, produto da reunião entre Obenga (diretor geral do Centro) e M'Bow (diretor geral da UNESCO):

[O]s propósitos do CICIBA são conservar, promover e preservar os
valores reais das civilizações bantu e que, para tanto, é
nomeadamente necessário, para cooperar com as instituições
nacionais e internacionais de natureza cultural, acadêmica e
educacional, dando prioridade e intensificando a cooperacão entre os
países da zona bantu [...] (DRAFT AGREEMENT, 1986, p.1 -
tradução livre, grifos nossos)

Nesse sentido, aqueles arqueólogos que trabalhassem e residissem no continente africano deveriam participar da construção e divulgação do conhecimento arqueológico endógeno com a publicação das notícias das suas pesquisas no boletim Nsi.

\footnotetext{
${ }^{116}$ The purposes of CICIBA are to conserve, to promote and to preserve the real values of the Bantu civilizations and that, for those purposes, it is required inter alia, to co-operate with national and international institutions of a cultural, academic and educational nature while giving priority to and intensifying co-operating between countries of the Bantu zone [...] (DRAFT AGREEMENT, 1986, p.1)
} 
Bernard Clist, editor do Nsi, entre os anos de 1987 a 1992, escreveu os editoriais dos números quatro a onze, dos anos de 1989 a 1992. Ele nasceu na França e formou-se em arqueologia na Brussels University, na Bélgica. Em 1980, especializou-se em Arqueologia da África Central com estudos sobre os primeiros assentamentos "neolíticos" da região da floresta úmida. Além da editoração do Nsi, participou entre 1985 e 1991, da formação do banco de dados do CICIBA com informações linguísticas, históricas, arqueológicas, etnográficas sobre os povos de língua bantu, como já mencionado anteriormente. Desde 1991, Clist participa de projetos de arqueologia preventiva e de salvamento e estudos de impacto ambiental na África pela Arqueologia de Contrato. Atualmente, também administra o diretório AFRICANARCHAEOLOGY.NET que disponibiliza gratuitamente o boletim Nsi (THE ANTHROPOLOGY BACK DOOR TO THE WEB, acesso em 20/12/2012).

Figura 22 - Bernard Clist, s.d.

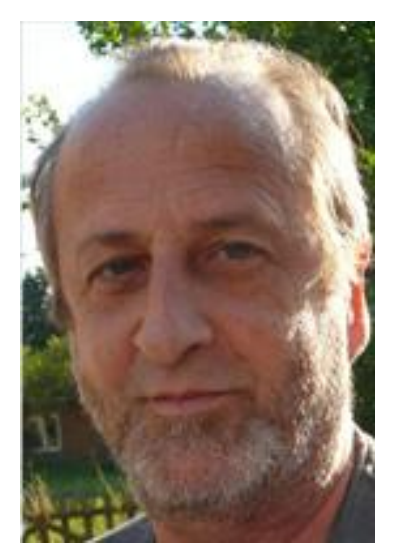

Fonte: THE ANTHROPOLOGY BACK DOOR TO THE WEB, acesso em 20/12/2012.

Raymond Lanfranchi foi editor do Nsi entre os anos 1987 e 1991. Conforme Hardin (1998, p.37-38), Lanfranchi desenvolveu, juntamente com os seus estudantes, estudos importantes sobre a região do Rio Sangha - entre Camarões, República Centro-Africana e República do Congo. Nessas pesquisas arqueológicas, delineou modelos de difusão da metalurgia pelos povos de língua bantu entre os anos 500 a.C e 500 d.C. Ainda, segundo a Hardin (1998), o estudioso preocupou-se com a participação dos arqueólogos africanos na produção do conhecimento sobre a África e a participação dos "ocidentais" nessa empreitada da seguinte maneira: 
[O]s investigadores ocidentais podem contribuir para fazer mais produtivas as capacidades de pesquisa nos países da África onde eles trabalham, concedendo a formação e viabilizando as possibilidades de disseminação pública para os colaboradores africanos. (Hardin, 1998, p.38 - tradução livre) ${ }^{117}$

Pierre De Maret (1985), manifestando gratidão, apresentou várias datações obtidas pelas pesquisas de Lanfranchi sobre a África Central, datas radiocarbônicas não publicadas até aquele momento. Seus livros escritos e publicados, identificados na pesquisa são: Paysages quartenaires de l'Afrique Centrale Atlantique (1990); Aux origines de l'Afrique Centrale (1991); e, L'archéologie préventive en l'Afrique (2008).

Figura 23 - Raymond Lanfranchi, s.d.

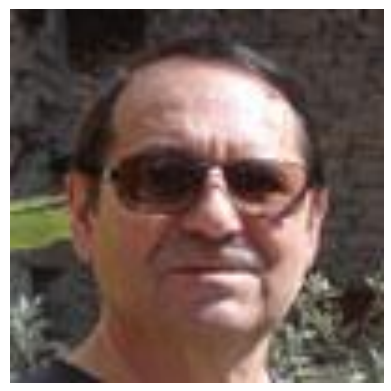

Fonte: KONGOKING PROJECT, acesso em 15/12/2012.

$\mathrm{Na}$ perspectiva dos editores Théophile Obenga, Bayona-ba-Meya, Bernard Clist e Raymond Lanfranchi, entre os anos de 1987 e 1990, era de responsabilidade dos arqueólogos africanos e aqueles que trabalhavam e residiam na região, sustentar com relatórios o cumprimento da missão solidária do Nsi de constituir uma rede de intelectuais engajados na "africanização da arqueologia". Esta é especificada com o envio de relatórios e notícias desses especialistas, africanos ou residentes na África e, portanto, "mais capazes de compreender a realidade". Esta é a dedução obtida por nós incluindo a ideia subjacente do enunciado a seguir, o qual será apreciado nesse momento. Em editorial de 1989, número seis, Clist e Lanfranchi escreveram sobre a realização do primeiro seminário internacional dos arqueólogos do mundo bantu, ocorrido em Libreville, naquele mesmo ano:

\footnotetext{
${ }^{117}$ L'article qu'il [Lanfranchi] présente démontre non seulement le travail de recherche qui a été accompli et qui reste à faire, mais aussi la façon dont les chercheurs de l'occident peuvent contribuer à rendre plus fructueuses les capacities de recherche dans les pays d'Afrique où ils travaillent, en fournissant une formation et des possibilités de dissémination publique à leurs collaborateurs nationaux. (Hardin, 1998, p.38)
} 
[que reuniu] quase todos os arqueólogos residentes nos estadosmembros do CICIBA e algumas pessoas que trabalham no campo da arqueologia, incluindo historiadores. [...] Pela primeira vez, os nossos colegas encontraram-se fisicamente ao redor da mesma mesa e puderam associar os rostos com nomes e isso só poderá fortalecer a rede que já está em vigor nos estados-membros e em alguns outros países africanos. (Nsi, 1989, n.6, p. 5 - tradução livre, grifos nossos) ${ }^{118}$

Entretanto, o editor Clist, já sem a parceria de Lanfranchi, desde 1991, veiculou nos editoriais desse mesmo ano, números duplos, oito-nove, e de 1992, dez-onze, nos trechos transcritos anteriormente, a inconsistência da rede de arqueólogos africanos e africanistas, visto que, nesse período, tanto os anglófonos quanto os francófonos, não se interessavam mais pela publicação dos seus relatórios no Nsi. Além disso, o CICIBA e, especificamente, os departamentos de Arqueologia e o Museu, não se preocupavam mais pela constituição dessa rede "pan-africana" de arqueólogos especialistas na área bantu.

E mais, a falta de patrocínio dos países-membros, paulatinamente, manifestou-se nas finanças do boletim. Ba-Meya comentou, no editorial de 1988, número três:

[...] para lidar com a situação imposta pela conjuntura, nós distribuiremos agora o boletim NSI por assinatura. Calculamos apenas o custo anual por dois números: esse custo é muito baixo. $\underline{A}$ distribuição será sempre por via aérea. (Nsi, 1988, n.3, p.3 - tradução livre, grifos nossos) ${ }^{11}$

Em editorial de 1989, número cinco, Clist e Lanfranchi advertem:

Lembramos os nossos colegas que ainda não são assinantes que a nossa taxa de 3000 e 4000 francs CFA para as pessoas físicas é realmente barata. A prova está nas inscrições recebidas de vários estados-membros - por exemplo, do Congo [Brazzaville] - onde as condições econômicas dos pesquisadores são desfavoráveis. Os

\footnotetext{
${ }^{118}[\ldots]$ la presque totalité des archéologues en poste dans les Etats-Membres du CICIBA ainsi que certaines personnes oeuvrant dans le champ de l'archéologie, notamment des historiens. [...] Pour la première fois nos collègues se retrouvaient physiquement autour d'une même table; les visages s'associaient ainsi à des noms et cela ne pourra que renforcer le réseau déjà en place dans les EtatsMembres ainsi que dans quelques autres pays africains. (Nsi, 1989, n.6, p. 5)

119 [...] pour faire face à la situation que nous impose la conjoncture, nous distribuerons dorénavant le bulletin NSI par abonnement. Nous avons calculé au plus juste son coût annuel pour deux numéros: ce coût reste très modique. La distribution se fera toujours par voie aérienne. (Nsi, 1988, n.3, p.3)
} 
envios gratuitos que ainda existem em breve serão bloqueados: ASSINE. (Nsi, 1989, n.5, p.3 - tradução livre, grifos nossos) ${ }^{120}$

Essa ideia de exiguidade dos recursos econômicos e dos meios de comunicação terrestre - haja vista a necessidade de distribuição por via aérea do boletim - volta a ser evocada ao tratar das condições de inserção dos arqueólogos africanos e africanistas residentes na região. A cobrança das assinaturas não foi mais efetuada nos editoriais subsequentes.

Em 1991, ocorreram várias mudanças. A saída de Obenga da direção do CICIBA, que no ano seguinte passou a editar a publicação de egiptologia Revue Akhn e Lanfranchi saiu da editoração do Nsi. O newsletter Nyame Akuma, forte concorrente do Nsi em língua inglesa, já havia sido renomeado para Bulletin propagandeando para os arqueólogos melhores recursos para a produção, para a divulgação das notícias e dos relatórios das pesquisas em andamento e critérios mais rigorosos para a revisão do texto na editoração, como já abordado no capítulo anterior.

\section{A terminologia}

As imagens dos arqueólogos veiculadas nos editoriais do Nsi explicitamse na adoção das expressões identificadoras:
i) "africanos";
ii) "que trabalham na África";
iii) "que residem na África”;
iv) "francófonos, anglófonos e lusófonos"; e,
v) "colegas".

\footnotetext{
${ }^{120}$ Nous rappelons à nos collègues qui ne sont pas encore abonnés que notre tarif de 3000 et 4000 francs CFA l'année pour les personnes physiques est vraiment peu onéreux. La preuve en est faite par des abonnements reçus de plusieurs Etats-Membres - par exemple le Congo - où les conditions économiques des chercheurs sont défavorables. Les envois gracieux qui existent encore seront ainsi prochainement stoppés: ABONNEZ-VOUS. (Nsi, 1989, n.5, p.3)
} 
Os termos "arqueólogos africanos", "que trabalham" e "que residem na África" foram adotados nos três primeiros editoriais. Delimitavam o perfil dos autores colaboradores do boletim, que antes da publicação estavam isolados e, por isso, desconhecidos, pois tinham dificuldades de publicar os relatos dos importantes trabalhos que faziam. O advento do boletim Nsi foi a tentativa de um grupo de intelectuais do CICIBA, entre eles, o egiptólogo afro-centrista Obenga e o jurista Ba-Meya, de promover os arqueólogos africanos e aqueles que não eram africanos, mas que, nos dois casos, conhecessem as realidades das comunidades nativas e do contexto de inserção social, política e econômica dos arqueólogos na África. Nesse sentido, a imagem veiculada dos arqueólogos "africanos" e daqueles "que trabalham" e "que residem na África", nos editoriais do período entre os anos de 1987 e 1988, associa-se ao profissional eficaz, àquele mais qualificado e legitimado pela instituição científica CICIBA para publicar as notícias das pesquisas em andamento.

De outro modo, essa tentativa de promover os arqueólogos da região tinha outro objetivo: uni-los em uma rede de contatos que, em última análise, intenta a construção coletiva do conhecimento "endógeno" do pretérito dos povos de língua bantu.

Os termos arqueólogos "francófonos, anglófonos e lusófonos" e "colegas" foram adotados por Ba-Meya e pelos editores Clist e Lanfranchi e, posteriormente, somente por Clist para, de uma forma diferente, referir-se aos colaboradores e leitores do Nsi. O uso dessas expressões identificadoras era uma possibilidade de evitar a dicotomia entre "africano" e "não-africano", possivelmente sugerida pelo emprego das expressões utilizadas nos primeiros editoriais, já que ambos editores são franceses. A adoção desses termos, na nossa perspectiva, definia os arqueólogos colaboradores e leitores do Nsi através de um critério aparentemente "neutro": a língua do colonizador. Esse critério era uma forma de veicular a imagem dos arqueólogos colaboradores e leitores do Nsi independentemente do local do nascimento. No entanto, essa adoção, não deixa de estabelecer outra polarização visível nas acusações dos editores: a falta de interesse dos "anglófonos" no estabelecimento da rede de informações proposta pelo Nsi. 
O uso do termo "colegas" - Nsi, 1989, n.5, p.3; Nsi, 1989, n.6, p.5, Nsi, 1992, n.10-11, p.3, que definimos como aqueles especialistas que "trabalham juntos", é outro modo, veiculado pelos editoriais, para construir a imagem equiparada dos arqueólogos interessados na África dos povos de língua bantu, reforçando a ideia da necessidade de uma rede de contato, de interligação entre os arqueólogos.

Apesar dos esforços dos editores na elaboração imagética dos arqueólogos, visando atrair colaboradores e leitores e realizar a missão do Nsi, deduz-se que não foi completamente cumprida no seu período de circulação. Afinal, os editores tiveram uma grande dificuldade de atrair os arqueólogos, principalmente os anglófonos a fim de publicar as notícias das suas pesquisas de campo e estabelecer, na perspectiva editorial, uma rede unida e solidária de especialistas.

O CICIBA foi progressivamente exaurido de significado enquanto centro aglutinador de intelectuais com ideais pan-africanos. Concomitantemente, esvaziou-se de patrocínio político e financeiro por parte dos estados-membros, pelo que se depreende da falta de interesse em manter o Nsi, relatado por Bonhomme (2007, p.10) em AFRICAN-ARCHAEOLOGY.NET a, e o estado de abandono do edifício-sede do CICIBA, visível na figura dezenove, disponível em GABONECO.

Em 1993, os relatórios selecionados para sua veiculação foram publicados no boletim Nyame Akuma, na edição de número 39, no mês de junho (AFRICAN-ARCHAEOLOGY.NET a).

As atividades do Centro foram retomadas, atualmente, sob o patrocínio de Ali Bongo Ondimba, filho do ditador Omar Bongo, que idealizou o CICIBA (CICIBA.NET a). 


\section{ARQUEÓLOGOS: UMA TENTATIVA DE ARTICULAÇÃO DAS IMAGENS CONSTRUÍDAS}

\section{Pluralidade}

As construções discursivas contidas nos editoriais dos anos de 1987 a 1993, as quais veiculam as imagens sobre os arqueólogos, são caracterizadas por uma pluralidade que pouco aparece ao longo da trajetória dos boletins de modo isolado. Isso se deve à particularidade da fonte documental, os editoriais, representantes da parte hegemônica, isto é, do consenso dentro das sociedades SAAS, SAfA e a da instituição CICIBA. A pluralidade das imagens associada as suas funções, pode ser vislumbrada comparativamente nos editoriais dos boletins The South African Archaeological Bulletin, Nyame Akuma e Nsi.

Partimos de Bobbio (1997) e Sarlo (2005) a fim de embasar a nossa perspectiva comparativa das imagens dos arqueólogos e das suas funções no contexto histórico de produção dos editoriais.

Bobbio (1997) analisa a prática discursiva sobre os intelectuais, que na nossa abordagem, interpretamos como os arqueólogos, chamados de sábios no passado, produtores e transmissores de ideias, portadores do poder ideológico (BOBBIO, 1997, p. 11). Ainda para ele, os discursos sobre os intelectuais têm caráter:

i) Descritivo - o que são e o que fazem;

ii) Normativo - o que devem ser e devem fazer, por exemplo, segundo as sociedades científicas;

iii) Prescritivo - o que, por exemplo, os editores esperam deles; e,

iv) Programático - o que os deverão ser e fazer no futuro.

Consideramos que os editoriais dos boletins são discursos que apresentam as características elencadas e que puderam ser apreciadas nos trechos dos editoriais transcritos nos capítulos da parte II dessa dissertação. 
Nessa apreciação, identificamos que as práticas discursivas sobre os arqueólogos revelam as dificuldades em lidar com as demandas sociais dos especialistas no período analisado. Portanto, a constituição das imagens dos arqueólogos emergidas na era pós-colonial, veiculadas pelos editoriais do TSAAB, Nyame Akuma e Nsi, atrela-se a essas dificuldades.

Assim, a construção imagética, como não poderia deixar de ser, está imersa no contexto histórico e ideológico da disciplina arqueológica dentro e fora da África, desde o final da Segunda Guerra Mundial e, mais explicitamente, nas décadas de 1980 e 1990 (TRIGGER, 1984, 2004; SHEPHERD, 2002, 2003; ROBERTSHAW, 1990; HODDER, 1996, 2003; SAID, 2005).

Uma dessas imagens, veiculadas nos editoriais do TSAAB, referia-se à forma como os arqueólogos se representavam perante a sociedade leiga, no contexto do regime segregacionista. A estratégia para a identificação e análise das imagens dos arqueólogos sul-africanos foi elencar a recorrência das palavras-chave principal Gestão Patrimonial ou pelas palavras-chave secundárias Patrimônio Arqueológico e Legislação e o modo como os enunciados relacionavam-se com outros do mesmo editorial ou de outra edição.

A recorrência dos enunciados sobre as palavras-chave identificadas, no período analisado, entre os anos de 1987 e 1993, integra as discussões sobre a gestão comunitária do patrimônio arqueológico, ou seja, o domínio público sobre o passado, como consta em Hodder (1989, p.272-273). Retornemo-nos para a natureza das formações discursivas dos editoriais e do jogo de regras pertinentes à construção imagética.

Notamos que, na verdade, os editoriais tratam de dirimir 0 questionamento, próprio da gestão comunitária, sobre quem tem legitimidade de produzir e divulgar o conhecimento sobre o pretérito: os arqueólogos da sociedade científica, os amadores, o Estado ou a comunidade nativa. Nesse ponto, a função associada à imagem dos arqueólogos sul-africanos é controlar - apartar - o contato da população com os sítios arqueológicos e históricos através do impedimento do acesso, da legislação e da legitimidade do detentor 
do saber arqueológico que estuda o longínquo passado do continente, alienado de sentido para os sul-africanos "coloreds" e "blacks" em um regime segregacionista.

Nessa perspectiva metodológica, identificamos outra imagem veiculada nos editoriais, a qual faz menção à representação dos arqueólogos diante dos pares. Essa imagem os retratava enquanto pertencente a um grupo definido separado do restante da sociedade leiga, o que poderia implicar, dependendo da opção ideológica, em não comprometimento com partes contentoras, com o isolamento e introspecção e, por fim, com o desenraizamento da sociedade civil (BOBBIO, 1997; SAID, 2005). Esse grupo de especialistas era definido pelas regras das sociedades SAAS e SAfA e a instituição CICIBA, divulgadas pelos editoriais, que como vimos, têm caráter descritivo, normativo, prescritivo e programático.

As práticas discursivas nos editoriais do TSAAB, Nyame Akuma e Nsi intentaram veicular as imagens dos arqueólogos como um grupo homogêneo com a adoção de termos envolventes (HODDER, 1989; TILLEY, 1989; CORACINI, 2007): "colegas", "pesquisadores", "nós", "vocês". Entretanto, a pluralidade imagética revelou-se no grau elevado das tensões manifestadas na adoção das expressões de diferenciação nos enunciados: "africanos", "sulafricanos", "africanistas", "não-africanos", "não-americanos", "que residem na África”, "que trabalham na África”, "anglófonos", "francófonos", "lusófonos".

Em nossa perspectiva comparativa, voltemo-nos para as imagens relativas ao termo "arqueólogos africanos". Diouf (1993), Boulaga (1993) e Mama (2004) analisaram as identidades dos intelectuais africanos na era póscolonial. Segue-se um trecho de Mama (2004):

As complexidades da era pós-colonial têm gerado novas identidades intelectuais africanas que são contraditórias na sua diversidade, mutantes, múltiplo-constituídas e cosmopolitas, localizadas em epistemologias que devem tanto aos movimentos sociais da África, às sociedades civis e às comunidades e redes independentes de pesquisa como devem para os estabelecimentos acadêmicos formais. (MAMA, 2004, p.03 - tradução livre) ${ }^{121}$

\footnotetext{
${ }^{121}$ The complexities of the postcolonial era have generated new African intellectual identities that are contradictory in their diversity, peripatetic, multiply-constituted and cosmopolitan, located in epistemologies that are likely to owe as much to Africa's social movements, civil societies and
} 
A adoção do termo "africano" enquanto identidade intelectual é contextualizada não apenas nos editoriais. Segundo Diouf (1993, p.), quando se analisa as imagens dos intelectuais africanos parte-se de um problema de origem pertinente à sua "exterioridade" em relação às sociedades, onde a palavra, ou melhor, a "oralidade é soberana" (cf. BOULAGA, 1993, p.30). Nos primeiros editoriais do $N s i$, conforme análise realizada no capítulo seis, o termo "africanos" foi empregado para referir-se aos arqueólogos melhor qualificados e legitimados para colaborar com o boletim, pois, conhecem "de perto", internamente, as realidades locais. Depreende-se dos usos do termo nos enunciados que essa construção imagética promove esses intelectuais africanos que apresentam uma perspectiva "interna" e por isso, legítima, da pesquisa arqueológica, embora estejam isolados, seja pelas distâncias entre eles, seja pelos critérios de publicação científica, majoritariamente em língua inglesa, como por exemplo, o Nyame Akuma e o TSAAB.

De outro modo, os editoriais do newsletter e, posteriormente, do boletim Nyame Akuma apresenta o uso do termo "africanos" enquanto designação dos especialistas com dificuldades para obter a "moeda forte" - o dólar americano para pagar as assinaturas do boletim. Assim, ficavam impossibilitados e dependentes de auxílio, no ponto de vista dos editores, para colaborar com um meio de comunicação dos pesquisadores associados à SAfA. Essa imagem difere da construída no boletim Nsi, que podemos considerar entusiasta, a qual reclama a agência dos arqueólogos, nascidos ou não na África, mas atuantes na área bantu e sobre a produção e veiculação do conhecimento arqueológico.

Esses pesquisadores associados da SAfA eram identificados como "africanistas" e, gradualmente, passaram a ser considerados como "nãoafricanos". Concomitantemente, vimos nos editoriais do Nyame Akuma que o termo "africanos" foi, progressivamente, vinculado ao termo "não-americano". Os editoriais do newsletter-boletim, produzidos em meio à dominância da abordagem pragmática e positivista da Nova Arqueologia estadunidense e a 
busca de independência da abordagem canadense, expressam duas tentativas.

A primeira delas, explicada pela opção ideológica da neutralidade e objetividade científicas da Nova Arqueologia, de distanciamento das questões do contexto social, político e econômico dos arqueólogos "africanos" e "nãoamericanos" assinantes do Nyame Akuma. Esse distanciamento foi expresso com a interrupção dos envios das edições gratuitas e o envio das edições dos "africanos" pagantes por correio terrestre.

Outra tentativa, fracassada, de neutralidade e objetividade científica na divulgação do conhecimento arqueológico da África, por africanistas, ou seja, todos os interessados nos estudos africanos, foi atestada no uso, por parte dos editores, do termo de auto referência "americanos", adicionada à palavra de negação "não" (cf. TILLEY, 1989, p.278).

Depreende-se que, nas duas tentativas, a construção imagética dos arqueólogos "africanos" ficou associada à dependência econômica, herança colonial, potencializada pelo discurso paternalista, próprio do discurso colonial. Nesse sentido, Moro-Abadia (2006) afirma:

[O] "discurso colonial" pode ser definido como um discurso (no sentido de Foucault) que produz conhecimento sobre os povos colonizados a fim de legitimar a dominação colonial. Esse discurso constitui um tipo específico de poder simbólico que serve para legitimar um ponto de vista hegemônico e colonialista. (MOROABADIA, 2006, p.7)

Seguindo esse raciocínio, os editoriais do TSAAB especificam essa construção imagética com o uso do termo "sul-africano". Houve a recorrência nos editoriais das palavras-chave principal e secundária correspondentes aos cuidados com a gestão do patrimônio arqueológico e a formulação dos enunciados relativos às atitudes dos profissionais e leigos "perante" a arte rupestre. A imagem dos arqueólogos sul-africanos construída nesses editoriais responde a uma demanda da sociedade científica e dos administradores por profissionais associados e treinados na tradição anglo-americana que podem

\footnotetext{
${ }^{122}$ In short, 'colonial discourse' can be defined as a discourse (in Foucault's sense) that produces knowledge about colonized people in order to legitimate colonial domination. This discourse constitutes a particular kind of symbolic power which serves to legitimate a hegemonic and colonialist point of view. (MORO-ABADIA, 2006, p.7)
} 
administrar esse patrimônio arqueológico e oferecer interpretações sobre os vestígios, em um momento de transição, o fim do regime segregacionista.

Conforme Shepherd (2000, p.147), entre os anos de 1923 e 1993, aproximadamente $97 \%$ dos arqueólogos profissionais do país eram brancos, o que recai sobre as identidades dos arqueólogos sul-africanos colaboradores e leitores da publicação ligada à sociedade arqueológica SAAS. Por outro lado, a arqueologia sul-africana é fruto da tradição anglo-americana da Nova Arqueologia - Processualismo - e, nesse sentido, Shepherd (2002, p.197; 2003, p.826) veicula duas imagens dos arqueólogos da região entre 1870 a 2003. A primeira seria a daqueles cientificamente "desengajados" e, a segunda, daqueles "engajados", dando voz aos povos do passado recente, tendo implicações tanto na ciência arqueológica quanto na relação com a sociedade. Podemos ainda citar Said (2005):

\begin{abstract}
Mesmo os intelectuais que são membros vitalícios de uma sociedade podem, por assim dizer, ser divididos em conformados e inconformados. De um lado, há os que pertencem plenamente à sociedade como ela é, que crescem nela sem um sentimento esmagador de discordância ou incongruência e que podem ser chamados de consonantes: os que sempre dizem "sim", e, de outro, os dissonantes, indivíduos em conflito com sua sociedade e, em consequência, inconformados e exilados no que se refere aos privilégios, ao poder e às honrarias. (SAID, 2005, p.60)
\end{abstract}

$\mathrm{Na}$ nossa perspectiva, a imagem dos arqueólogos sul-africanos veiculados nos editoriais "pende" devido ao difícil diálogo com a sociedade civil, consequência da dominância da abordagem da Nova Arqueologia e das críticas propostas pela Arqueologia Pós-processual e de perspectiva Póscolonial, nos anos de 1987 e 1993 (cf. COPANS, 1993).

Problematizamos a adoção dos termos "africanistas", "não-africanos", "que residem na África", "que trabalham na África", "anglófonos", "francófonos" e "lusófonos" na construção das imagens divulgadas nos editoriais analisados. De modo geral, estas adoções são tentativas de definir um grupo por critérios diversos de nascimento, de área de estudo e atuação e de língua do colonizador.

O uso do termo "africanistas", mais recorrente nos editoriais do Nyame Akuma, uma publicação da Society of Africanists Archaeologists, procura 
identificar os especialistas interessados nos estudos africanos. Isso significa, nos primeiros editoriais do newsletter e nos primeiros editorais do nosso corpus, identificar e promover um grupo idealizado de intelectuais, acima das divisões subjetivas, quanto ao local de nascimento, ao posicionamento ideológico ou ao poder econômico.

O termo "não-africanos" adotado no Nyame Akuma aparenta tratar de uma diferenciação pelo local de nascimento. Esse uso denota o destaque do poder econômico e, portanto, a disposição de maiores e de melhores recursos para pertencer a uma rede de informações de arqueologia. Esse uso associado à construção da imagem do arqueólogo reforça outra, a do arqueólogo "africano" carente de meios e recursos para "desenvolver" a arqueologia africana, com métodos e materiais, especificamente pensados em uma abordagem "endógena" (cf. BAGODO, 2004).

No caso, do boletim Nsi, a adoção dos termos identificadores arqueólogos "que residem" e "que trabalham na África" - é uma estratégia da construção imagética dos especialistas da área bantu, recorrendo ao expediente do conhecimento das realidades locais, independente do local de nascimento (cf. DIOUF, 1993). Nota-se que nos editorais do boletim Nsi, diferentemente dos do Nyame Akuma e do The South African Archaeological Bulletin, o destaque do envolvimento dos arqueólogos com os contextos sociais, e também, com as formas dialógicas de pesquisa sobre o patrimônio arqueológico. A adoção desses termos aponta os critérios para identificar os arqueólogos da rede pretendida como missão do boletim, aqueles estabelecidos na área bantu.

Os termos relacionados à construção imagética dos arqueólogos "anglófonos", "francófonos" e "lusófonos", presentes nos editoriais do Nsi, apresentam especificações quanto à língua de publicação científica: a inglesa, a francesa e a portuguesa, um legado colonial. Atribuiu-se, nos anos de 1987 até 1993, mais visibilidade às publicações de língua inglesa, caso do Nyame Akuma. O boicote científico ao regime segregacionista sul-africano implicou no desinteresse dos arqueólogos em publicar em um boletim como o TSAAB. 
O boletim Nsi é uma das estratégias de divulgação da ciência arqueológica produzida localmente, com verbas próprias dos países-membros, liderados pelo ditador Omar Bongo, do Gabão e da instituição CICIBA. A arqueologia sobre os povos bantu, especificamente, sobre o passado recente da região, financiada pelos governos locais e pela UNESCO, como apontado nos editoriais do Nsi, a nosso ver, ultrapassa a ideia de uma versão autóctone e endógena produzida por africanos "de nascimento". Consideramos que, houve a criação de uma rede local, com arqueólogos identificados, nos editoriais de Clist e Lanfranchi e, posteriormente, nos de Clist, pelos termos relativos ao estabelecimento na região ou à língua. A construção imagética dos arqueólogos, produtores locais da arqueologia dos povos bantu, divulgada pelo boletim Nsi, veicula que mesmo que não tenham nascido na África, mas vivem intensamente as realidades locais, participam da construção de uma arqueologia africana.

Dessa forma, o uso dos termos relativos à construção das imagens dos "africanos", "africanistas, "sul-africanos", "não-africanos", "não-americanos" e "que residem" e "que trabalham na África", "anglófonos", "francófonos", "lusófonos", "colegas", "pesquisadores", revelam, de forma contextualizada, a pluralidade de identidades atribuídas aos intelectuais, precisamente, aos arqueólogos nos editorais analisados (MAMA, 2004; TOULABOR, 1993).

\section{Relações de poder}

Sarlo (2005) e Bobbio (1997) afirmam que o poder político e os discursos dos intelectuais, expressão do poder ideológico, apresentam uma relação instável e esta muda conforme as novas conjunturas históricas. Nesse raciocínio, as imagens dos arqueólogos e as funções dessas alteraram-se ao longo das conjunturas históricas, desde o final da Segunda Guerra Mundial até o período do nosso recorte temporal, anos 1987 a 1993.

$\mathrm{Na}$ nossa perspectiva, as circunstâncias históricas influenciaram largamente a construção de imagens de arqueólogos relacionados às dimensões políticas e ideológicas da construção dos Estados africanos, mesmo 
que isso esteja implícito nos editoriais dos três boletins analisados: The South African Archaeological Bulletin, Nyame Akuma e Nsi.

Ainda na primeira metade do século XX, de acordo com M'Bokolo (2011, p.546), as elites intelectuais, imbuídas da preocupação científica pautada pela busca da verdade e da exploração política do saber, deram origem a uma geração de intelectuais africanos, entre 1920 e 1960, com grandes contribuições nas áreas da evolução humana, da história antiga e da arqueologia das civilizações africanas pretéritas. Apesar da "emergência da elite colonial africana respondesse ao desejo do sistema colonial de criar uma categoria de 'indígenas' para os cargos administrativos e comerciário necessários." (DIOUF, 1993, p. 40 - tradução livre) ${ }^{123}$. A geração de intelectuais, africanos e africanistas, munidos teoricamente da perspectiva panafricana estavam preocupados em demonstrar a maestria das antigas civilizações africanas.

Segundo M'Bokolo (2011), o conceito do Pan-Africanismo, publicado por William Edward Burghardt Du Bois (1868-1963), embasou as ideias de luta de intelectuais africanos contra os abusos do colonialismo, pela independência e pela busca da unidade africana. A associação dos intelectuais africanos levou à formação de grupos políticos militantes, como por exemplo, a União SulAfricana (ANC), que questionavam a supremacia ou invencibilidade dos brancos, imagem implodida com a capitulação das metrópoles coloniais durante o conflito mundial (M'BOKOLO, 2011, p.551, 553, 565).

O poder de produzir e de transmitir ideias foi pulverizado entre diferentes grupos nas décadas de 1980 e 1990 (HODDER, 1989). Sarlo (2005, p.142-143) salienta que um contexto histórico marcado pela mobilização social levou a um encontro entre os discursos científico e político. Esse ponto de encontro é marcado pela instabilidade que é característica da relação entre esses discursos. A autora, ainda, considera a funcionalização das atividades intelectuais em relação às atividades políticas visando intervir no ou duplicar o debate político.

\footnotetext{
${ }^{123}$ L'émergence de l'élite coloniale africaine répond au désir du système colonial de forger une catégorie d'indigènes pour les besoins administratifs et commerciaux. (DIOUF, 1993, p.40)
} 
Entendemos que o final da década de 1980 e ao longo da década de 1990, os posicionamentos políticos-ideológicos dos arqueólogos adeptos da corrente da Arqueologia Pós-Processual estimularam a consolidação das sociedades científicas enquanto portadoras do discurso sobre o arqueólogo participante da sociedade civil. Quem controla o acesso aos vestígios pretéritos e de que modo às interpretações sobre o passado são "consumidas" pelo público? (TILLEY, 1989, p.279). As respostas a essas questões definem a função social dos arqueólogos no período.

Para Shepherd (2003), nas décadas de 1970 e 1980, a progressiva profissionalização e especialização da disciplina, fatos esses associados à adesão dos profissionais aos paradigmas cientificistas da corrente da Nova Arqueologia e a injeção de financiamento pelo regime segregacionista, fomentou o crescimento e a legitimação do poder das sociedades científicas na constituição de um saber arqueológico e de uma imagem de arqueólogo descolado da sociedade (cf. FOUCAULT, 1972). Segundo Moro-Abadia (2006, p.7):

[A] crença na autonomia da ciência e da fé na neutralidade da ciência [...] decisivamente influenciaram a orientação "interna" da história da arqueologia entre 1870 e 1970 e, por isso, elas [autonomia e neutralidade da ciência] marcaram a maneira como os historiadores da arqueologia interpretaram a relação entre a prática arqueológica e o colonialismo. (MORO-ABADIA, 2006, p.7) ${ }^{124}$

Nos anos 1980 e 1990, o novo discurso pós-colonial potencializado pelo boicote científico proposto pela ONU à África do Sul acarretou no banimento dos arqueólogos desse país e da Namíbia, este último sob a hegemonia sulafricana. A Arqueologia sul-africana possui raízes na relação simbiótica entre a SAAS e o governo de Jan Smuts e, posteriormente, no regime do apartheid, que não é de modo algum assumido nos editoriais, mas é implícito pelas consequências sofridas pelos arqueólogos sul-africanos (boicote).

\footnotetext{
${ }^{124}[\ldots]$ the belief in the autonomy of science, and the faith in the neutrality of science $[\ldots]$ decisively influenced the 'internalist' orientation of the history of archaeology between 1870 and 1970 and, therefore, they marked the way in which historians of archaeology interpreted the relationship between archaeological practice and colonialism. (MORO-ABADIA, 2006, p.7)
} 
Os editorais do The South African Archaeological Bulletin construíram especificamente a imagem dos arqueólogos sul-africanos como produtores de conhecimento descolados da sociedade civil, o que difere dos editoriais do Nsi. Porém, a aproximação da sociedade apresentada é a ênfase na imagem dos arqueólogos enquanto educadores patrimoniais, objetivando a preservação do patrimônio para o estudo. Essas imagens veiculadas nos editoriais têm como função reorientar os arqueólogos sul-africanos, leitores do boletim do TSAAB, em um momento de ruptura da trajetória política e social da arqueologia na África do Sul com o empoderamento das comunidades nativas na perspectiva da Arqueologia Pós-Colonial, Pós-Processual no fim do regime segregacionista.

A perspectiva teórica processualista imbuída de neutralidade científica e de pragmatismo, empregada pelos editores do TSAAB, servia como um "escudo" a qualquer crítica "pós-processualista" ou "pós-colonial" ao silêncio desses especialistas perante as atrocidades do regime (cf. HODDER, 1989, p.269-271). Daí advém o argumento de sua vitimização presente nos editoriais do TSAAB sobre o seu banimento do World Archaeological Congress de 1986 (WAC-86) (cf. GOLSON, 1986; UCKO, 1987). Outro argumento presente nos discursos é que eles foram impedidos de participar desse congresso e de outros eventos, porque, os colegas estrangeiros, sem respeitar os princípios da liberdade acadêmica e da neutralidade científica, os identificaram como representantes do país. Os arqueólogos sul-africanos, nos editoriais posteriores ao WAC-86, queriam ser vistos como cientistas dissociados da vida política e social do seu país.

Para Hountondji (1995), ao longo do regime colonial, houve a falta de procedimentos construtivos dos modelos teóricos endógenos, devido às dificuldades na pesquisa básica, à falta de laboratórios e ausência de universidades acessíveis aos africanos. Segundo Hassan (1999) ocorreu, na arqueologia africana, à adoção dos métodos e modelos teóricos como heranças coloniais que ainda persistem. Nesse sentido, Munanga (1983) analisando a situação atual da Antropologia Africana afirma: 
de produção dos sistemas de linhagem não deixam de participar deste projeto político ocidental. (MUNANGA, 1983, p.158)

Sobre a Arqueologia Africana Hountondji aponta (1995):

Tivemos apenas centros das chamadas pesquisas aplicadas que
permitiram, em primeiro lugar, a reunião febril de todas as
informações supostamente úteis voltadas para exportação imediata à
metrópole e de forma secundaria, uma ocasional, a aplicação
apressada e limitada das pesquisas metropolitanas em algumas
questões locais. (HOUNTONDJI, 1995, p.02 - tradução livre)

Esse modo de produção de conhecimento científico, segundo o autor, é uma especificidade do paradigma da atividade econômica no qual os países africanos inserem-se. Segundo Hountondji (1995, p.03), a produção científica, enquanto bem imaterial, define-se pela produção dos bens materiais. Se a extroversão é uma característica do modelo econômico produtor de bens materiais e dos imateriais para a satisfação do mercado consumidor das metrópoles, a África encontra-se na periferia da produção de conhecimento científico, caracterizada pela dependência científica, extroversão e subdesenvolvimento científico (HOUTONDJI, 2008). A divisão internacional do trabalho é reforçada pelas dificuldades de acesso aos meios de publicação das pesquisas pelos africanos o que se deve a uma relação vertical entre os arqueólogos africanistas e africanos e a continuada formação e migração para exterior dos intelectuais de alto nível.

Apesar das epistemologias hegemônicas do Ocidente, o desenvolvimento de alternativas procedimentais e teóricas e o diálogo dessas com as metodologias arqueológicas tradicionais, como, por exemplo, com o estabelecimento do boletim $\mathrm{Nsi}$, foi uma das condições das mudanças emergentes da era pós-colonial (cf. SAID, 2005; MORO-ABADIA, 2006). No entanto, algo essencialmente perceptível no corpus documental e, que é indicado por Shepherd (2003), seria o distanciamento entre Arqueologia e o contexto social de inserção dos arqueólogos nos editoriais do The South African Archaeological Bulletin e o Nyame Akuma.

\footnotetext{
${ }^{125}$ We only had centers for so-called applied research that allowed, first, the feverish gathering of all supposedly useful information, aimed for immediate exportation to the so-called mother country and secondly, an occasional, hasty and limited application of metropolitan findings to some local issues. (HOUNTONDJI, 1995, p. 02)
} 
Essa atitude de distanciamento pode estar relacionada à instrumentalização do rigor e da ideia de neutralidade presentes na orientação da Nova Arqueologia, indicada pelos editores do TSAAB e NA (cf. HODDER, 1989, p.268-271; SHEPHERD, 2002, p.198). Conforme Shepherd (2003):

No cerne da noção da arqueologia como ciência está a ideia de que é
um refúgio da sociedade. De uma forma ou de outra, o retiro tem sido
uma característica permanente da arqueologia sul-africana; da
arqueologia colonial cujos estudos esquivavam-se da sociedade
africana, para o período pós-1970, onde a arqueologia estava
afastada da sociedade em geral. (SHEPHERD, 2003, p. $844-$
tradução livre)

A ideia de pluralidade de autores ou de abordagens nos editoriais subsume-se ao corporativismo das sociedades arqueológicas, as quais se assentam sobre princípios unificadores, constatado com a assimilação do Nsi pelo Nyame Akuma (cf. SARLO, 2005, p.146).

Alguns desses princípios unificadores referem-se ao entendimento sobre a atuação dos arqueólogos: dentro do mundo acadêmico, orientando o governo e a sociedade. O fechamento dos membros dentro da sociedade arqueológica já não era possível entre 1987 e 1993, considerando as atribuições citadas, porém, ainda havia insatisfação por parte dos colegas do WAC-86 e dos intelectuais africanos mais combativos, pois esses membros não se posicionavam diante da política.

Daí, a negação dos aspectos contraditórios dos discursos dos arqueólogos nessas sociedades científicas, visto que o lugar do arqueólogo foi idealizado e construído fora da sociedade civil e com limites de atuação claros e estabelecidos pela sociedade arqueológica.

Nesse sentido, se diante da mobilização social dos arqueólogos nos anos de 1980 e de 1990, o discurso dos editores direciona-se ao do político consonante, evita-se a instabilidade inerente perante o encontro dos discursos científico e político revelada por Sarlo (2005).

\footnotetext{
${ }^{126}$ At the heart of the notion of archaeology as science is a retreat from society. In one guise or another, such a retreat has been an abiding feature of South African archaeology; from colonial archaeology in its studious avoidance of African society, to the period post-1970 which was in retreat from society at large. (SHEPHERD, 2003, p.844)
} 
Podemos deduzir três pontos de vistas subjacentes e relacionados quanto às imagens dos arqueólogos africanos veiculados pelos boletins. $O$ primeiro do Nyame Akuma, ligado a SAfA, onde o arqueólogo africano é visto como, inicialmente, parceiro, e, depois, como dependente de auxílio financeiro na divulgação do conhecimento produzido sobre o continente. Essa imagem dos especialistas reduz os atributos das identidades dos arqueólogos africanos e as possibilidades de auto-organização e desenvolvimento científico.

O segundo se refere aos editoriais $N s i$, vinculado ao CICIBA, que encoraja o especialista como parceiro na construção coletiva do conhecimento sobre arqueologia africana da área bantu, aproximando-o do "papel de protagonista". O que indicou uma resposta à demanda represada, expressa pela palavra "isolamento", sobre a capacidade local de organização institucional, de produção e de divulgação científica do conhecimento produzido localmente. Essa demanda que seria atendida pela criação do CICIBA foi financiada no contexto de interesses particulares do ditador Omar Bongo e dos governos de outros países-membros da região. Progressivamente, o desinteresse político, expresso na falta de "verbas próprias" para conduzir o projeto interdisciplinar do CICIBA e da sua publicação arqueológica Nsi, acarretou a sua desarticulação, exemplificada com a saída de Obenga da direção do Centro, em 1991, e no ano seguinte, a junção do Nsi ao Nyame Akuma.

Já, o terceiro ponto de vista, do The South African Archaeological Bulletin, uma publicação da SAfA, incita o distanciamento entre arqueologia e contexto social, político e ideológico e encoraja a aproximação do arqueólogo da sociedade como educador, aquele que ensina a postura "ocidental" perante o patrimônio arqueológico. Essa ideia compartilha a visão de objetividade e neutralidade científica, própria da Nova Arqueologia, de tradição angloamericana, corrente difundida tanto na África do Sul quanto na América do Norte, sede do Nyame Akuma.

A nosso ver, em meados da década de 1980, as dificuldades dos arqueólogos estabelecidos na África (ROBERTSHAW, 1990) em divulgar os seus trabalhos geraram uma demanda por uma publicação que não era suprida 
nem pelo TSAAB, boicotado, nem pelo Nyame Akuma, preocupada com o orçamento financeiro e com a suspensão dos envios das edições de forma gratuita para a África por via aérea. O Nsi surge como um boletim que responde a essa demanda represada de arqueólogos locais que queriam publicar em outras línguas, como o francês e português. Ainda responderia à demanda pela valorização do conhecimento produzido localmente de forma coletivizada em uma rede de informações sobre o passado dos povos de identidade Bantu, um projeto político e ideológico do CICIBA, financiado pelos governos locais. O contexto econômico de desvalorização monetária e inflação exauriu as finanças destinadas ao Centro. O Nsi foi impactado pela crise econômica dos países-membros financiadores.

Além disso, o Nsi deixou de circular por não cumprir completamente a sua missão de ligar os arqueólogos, tirando-os do isolamento. Isso se deve, de um lado, porque a publicação pode ter sido identificada como francófona, e, portanto, com menos visibilidade em comparação com outras publicações em língua inglesa (cf.VICTORA e MOREIRA, 2006; MENEGHINI e PACKER, 2007). De outro, devido à dificuldade de romper com os paradigmas coloniais que dificultam o estabelecimento de laços e a articulação entre os arqueólogos de diferentes origens e diversos posicionamentos ideológicos sobre a construção da Arqueologia da África e sobre a África (cf. SAID, 2005).

Após as análises dos discursos editoriais e das recorrências dos enunciados na construção das imagens dos arqueólogos, entendemos que união dos boletins Nyame Akuma e Nsi, a partir do ano de 1993, enquadra-se num restabelecimento de uma concentração de poder sobre a produção do conhecimento arqueológico na qual os próprios africanos passaram a concorrer (cf. HODDER, 1989, p.272).

Apropriadamente mantêm-se, sem maiores questionamentos, os privilégios concedidos aos membros da sociedade científica (SAfA). Entre esses privilégios está a consagração dos profissionais - editores e arqueólogos ideais - legitimados a escrever, falar e publicar de forma desigual sobre a arqueologia da África (FOUCAULT, 1972; TRIGGER, 1984; MORO-ABADIA, 2006). 
A edição do Nyame Akuma, número 39, de junho de 1993, publicou quatro relatórios de pesquisas realizadas no Camarões, um deles em língua francesa, e um relatório da pesquisa do antigo editor do Nsi, Clist, no Gabão, em língua inglesa ${ }^{127}$. A edição do boletim, número 40, de dezembro de 1993, publicou dois relatórios em francês sobre o Camarões, e um estudo realizado no Gabão, em língua inglesa ${ }^{128}$. O Camarões, considerado pelos estudiosos como o território onde ocorreu o início da expansão dos povos de língua bantu pela África subsaariana, foi privilegiado na produção editorial. Os outros países da África Central, pertencentes à área bantu, não foram cobertos no Nyame Akuma nessas duas edições.

Assim, podemos também concluir quanto à manutenção da concentração de estudos sobre as antigas áreas de interesse na pesquisa arqueológica da África Central com a junção das publicações Nyame Akuma e Nsi. Há a predominância da veiculação dos ideais ligados ao pragmatismo e à neutralidade científica, próprios da abordagem da Nova Arqueologia, presente em seus editoriais. Em relação à supremacia, prevalece a continuidade das relações de poder nos anos de 1987 até 1993 entre os arqueólogos "africanos", "africanistas", "não-africanos", "não-americanos", "sul-africanos", "que trabalham na África", "que residem na África", "anglófonos", "francófonos", "lusófonos" e "colegas".

\footnotetext{
127 "From clay to pottery, with style: 1990-1992 fieldwork in Cameroon" por Olivier P. Gosselain (p.2); "Archaeological research in northern Cameroon, 1992--the Projet Maya-Wandala" por Scott MacEachern (p.7); "Preliminary results of the 1991-1992 field season at Shum Lake, Northwestern Province, Cameroon" por P. de Maret, R. Asombang, E. Cornelissen, Ph. Lavachery, J. Moeyersons, e W. Van Neer (p.13); "Prospection des sites d'habitat dans les arrondissements de Djoum et Mintom (sud-Cameroun)" por Jean-Paul Ossah Mvondo (p.15); "Archaeological fieldwork and labwork in Gabon during 1992" por Bernard Clist (p.26). (NYAME AKUMA SUMÁRIO a)

128 "Etude pédologique dans un site archéologique de la région Forestière d'Ambam, Vallée du Ntem (sud-Cameroun)" por Jean Bosco Ella (p.5); "Recherches archéologiques dans la Vallée du Ntem, province du sud-Cameroun Méridional: premiers résultats du site de Mekomo" por J. Paul Ossah Mvondo (p.10); "The Neolithic/Iron Age transition in the middle reaches of the Ogodue valley in Gabon: chronology and cultural change” por Richard Oslisly (p.17). (NYAME AKUMA SUMÁRIO b)
} 
PARTE III - CONCLUSÃO 


\section{CONSIDERAÇÕES FINAIS}

Vimos que as sociedades e instituições científicas, especificamente as arqueológicas, são espaços fundamentais na manutenção de uma rede de intelectuais. Analisamos trinta e quatro editoriais oriundos dos boletins The South African Archaeological Bulletin, Nyame Akuma e Nsi, das respectivas sociedades científicas - SAAS, SAfA e CICIBA. Nessa análise investigamos a formação das múltiplas imagens dos arqueólogos africanos e africanistas na era pós-colonial da África, entre os anos de 1987 e 1993.

Era nosso objetivo identificarmos, e discernirmos, as imagens dos arqueólogos africanos e africanistas, sendo que, para isso, adotamos como referenciais os temas mais recorrentes no conjunto dos três boletins e os temas mais abordados em cada um dos editoriais. Esses temas foram apontados como as palavras-chave principais e secundárias dos editoriais pelas quais organizamos e tratamos o nosso corpus de pesquisa.

Partimos para a análise dos discursos veiculados pelos editoriais e da forma como os enunciados, relacionados às palavras-chave, eram construídos ao tomar por referência os arqueólogos africanos e africanistas enquanto autores dos editoriais dos boletins TSAAB, NA e Nsi e associados, respectivamente, da SAAS, SAfA e CICIBA.

Segundo a ótica de seus editores, os boletins do nosso corpus eram meios de comunicação rápidos e eficientes para cumprir as funções de informar o andamento das pesquisas de campo, informar quanto à realização dos congressos, e possibilitar que os arqueólogos entrassem em contato com os trabalhos realizados, bem como entrar em contato entre si.

Por fim, o foco da nossa análise, era, verdadeiramente, identificar as imagens ideais, assim como as rechaçadas, ou depreciativas, que retratavam os arqueólogos interessados na África. Vimos que essas imagens eram, de fato, construídas pelos editores, e veiculadas pelos editoriais na prática discursiva, formulando e consolidando enunciados recorrentes. 
As imagens veiculadas nos editoriais dos boletins The South African Archaeological Bulletin, Nyame Akuma e Nsi, baseadas nos estatutos que são, na verdade, o "jogo de regras" das sociedades SAAS, SAfA e CICIBA, têm função orientadora, exprimem o papel social dos intelectuais cujo objeto de estudo é a África e o papel da ciência arqueológica na África e sobre a África. Esta assertiva está baseada em nossa leitura de Foucault (1972).

Vimos que a elaboração das imagens nos editoriais apresenta especificidade que deu origem a uma terminologia mais complexa do que era esperada no início da pesquisa e cuja tônica tentamos expressar ao longo da nossa análise. Os termos "africanos" e "africanistas", identificados nas leituras iniciais da bibliografia, deram lugar à pluralidade de imagens manifestada nos editoriais, a se ver pelo surgimento de outros termos mais, como "sulafricanos", "não-africanos", "não-americanos", "residentes na África", "que trabalham na África", "anglófonos", "francófonos" e "lusófonos". Termos, entre outros, que refletiam os ranços da dominação colonial que persistiam na terminologia dos editores.

Esses diferentes termos ou enunciados, no sentido "foucaultiano", estavam atrelados aos contextos de inserção dos arqueólogos na sociedade leiga - ou seja, em tudo aquilo que não é sociedade científica - e da sua atuação e posicionamento corporativo diante do processo da, assim chamada, "descolonização da arqueologia africana".

Os questionamentos dos paradigmas coloniais apareciam nos temas abordados nos editoriais, como, por exemplo, a gestão do patrimônio arqueológico, enquanto agendas desse processo de "descolonização", na perspectiva dos editores. A partir da leitura dos editoriais e das nossas reflexões sobre as leituras de Said (2005), Foucault (1972), Bagodo, (2004), Hodder (1996, 2003), Karega-Munene e Schmidt (2010), e de Shepherd (2000, 2002, 2003), constatamos que essa "descolonização da arqueologia", no período analisado, se realizou apenas aparentemente, com evidente tom corporativista por parte dos arqueólogos não-africanos.

As relações de poder na divulgação do conhecimento arqueológico e as funções dos arqueólogos, próprias do discurso colonial, foram reproduzidas 
nos editoriais dos boletins das sociedades científicas. A tentativa de estabelecer uma alternativa a essa forma de divulgação, com a publicação do boletim Nsi - pertencente ao CICIBA, que é de origem uma instituição interdisciplinar africana - não foi bem sucedida face às estruturas econômicas e mentalidades impostas pela dominação colonial e face às heranças coloniais.

Nesta nossa análise recorremos não apenas a história da Arqueologia e aos fundamentos da teoria arqueológica, mas, também aos métodos históricos embasando-nos também nos estudos pós-coloniais sobre os discursos arqueológicos. Ela nos despertou para os significados atribuídos à identidade das sociedades de línguas bantu por arqueólogos profissionais, intelectuais da diáspora, pesquisadores amadores e políticos.

Começa, assim, a tomar forma um possível objeto análise para um próximo estudo. 


\section{ANEXOS}

\section{TABELAS}

1. PALAVRAS-CHAVE PRINCIPAIS

\begin{tabular}{ccccc}
\hline Palavras-chave principais & TSAAB & N.A. & NSI & TOTAL \\
\hline Agradecimentos e homenagens & 1 & 2 & 0 & $\mathbf{3}$ \\
Sociedade Científica & 2 & 0 & 1 & $\mathbf{3}$ \\
Organização do Boletim & 2 & 9 & 6 & $\mathbf{1 7}$ \\
Educação & 1 & 2 & 0 & $\mathbf{3}$ \\
Gestão Patrimonial & 8 & 0 & 0 & $\mathbf{8}$ \\
TOTAL & $\mathbf{1 4}$ & $\mathbf{1 3}$ & $\mathbf{7}$ & $\mathbf{3 4}$ \\
\hline
\end{tabular}

2. PALAVRAS-CHAVE SECUNDÁRIAS

\begin{tabular}{ccccc}
\hline Palavras-chave secundárias & TSAAB & N.A. & NSI & TOTAL \\
\hline Arqueologia comunitária & 1 & 0 & 0 & $\mathbf{1}$ \\
Assinaturas & 0 & 1 & 2 & $\mathbf{3}$ \\
Congresso & 2 & 3 & 1 & $\mathbf{6}$ \\
Ética & 2 & 1 & 0 & $\mathbf{3}$ \\
Informatização & 0 & 5 & 2 & $\mathbf{7}$ \\
Lançamento & 0 & 2 & 2 & $\mathbf{4}$ \\
Legislação & 2 & 0 & 0 & $\mathbf{2}$ \\
Obituário & 2 & 1 & 0 & $\mathbf{3}$ \\
Patrimônio Arqueológico & 4 & 0 & 0 & $\mathbf{4}$ \\
Roubo & 1 & 0 & 0 & $\mathbf{1}$ \\
TOTAL & $\mathbf{1 4}$ & $\mathbf{1 3}$ & $\mathbf{7}$ & $\mathbf{3 4}$ \\
\hline
\end{tabular}




\section{BASE DE DADOS}




\section{CATÁLOGO DAS FOTOGRAFIAS}

Figura 1 - Omar Bongo, s.d.

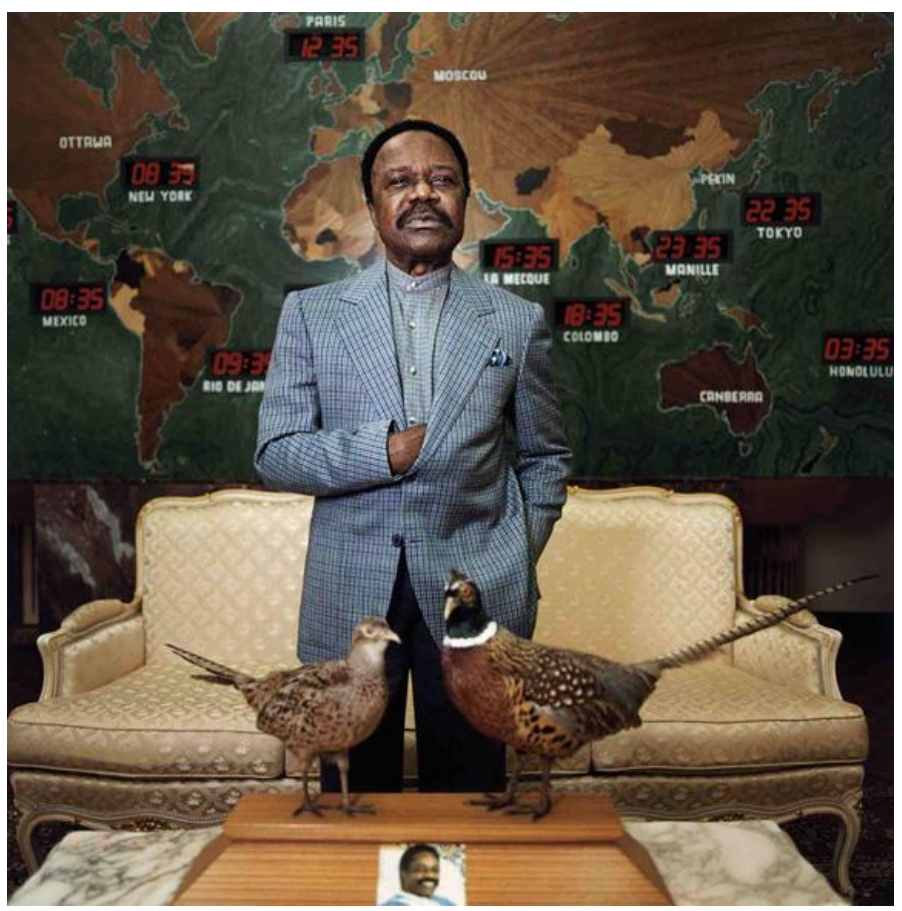

Fonte: LUDOVICCAREME.COM. Créditos: Ludovic Carème para o jornal Liberátion.

Bongo em uma pose "clássica" no seu escritório em Libreville. Segundo o fotógrafo Carème, foi o retrato que the deu mais preocupação. Ele ficou hospedado dois dias no local e o ditador Ihe deu quinze minutos para fazer esse retrato para o jornal Liberátion. (fonte: http://paratyemfoco.com/blog/2009/09/ludovic-careme/)

\section{Figura 2 - Astely John Hilary Goodwin}

\section{Fonte: INDIANA UNIVERSITY, acesso em 25/10/2012.}
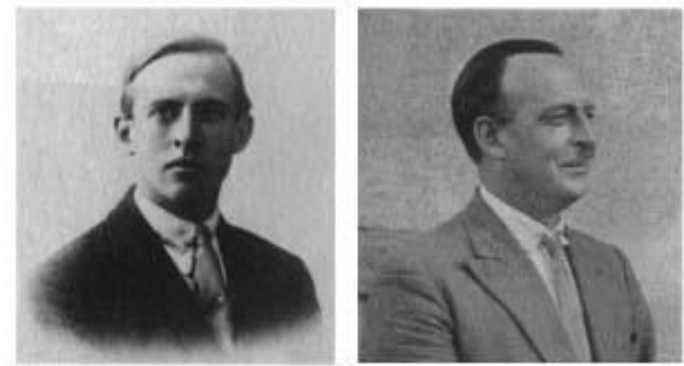

$$
\begin{aligned}
& \text { A.J. Goodwin: } \\
& \text { c. } 1918 \\
& \text { c. } 1932 \\
& \text { in } 1959
\end{aligned}
$$

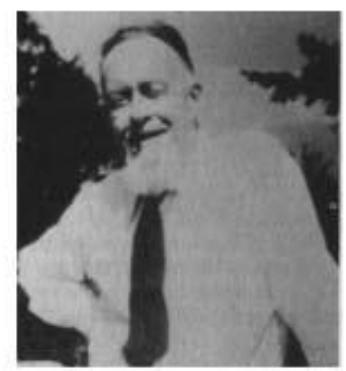

Goodwin, o primeiro arqueólogo profissional da África do Sul e fundador do boletim TSAAB, em três momentos de sua vida. 
Figura 3 - não apresenta fotografia.

Figura 4 - 0 arqueólogo Van Riet Lowe, sentado à esquerda, o general Jan Smuts, sentado ao lado de Lowe, e a equipe de escavação no sítio em Mapungubwe, 1930.

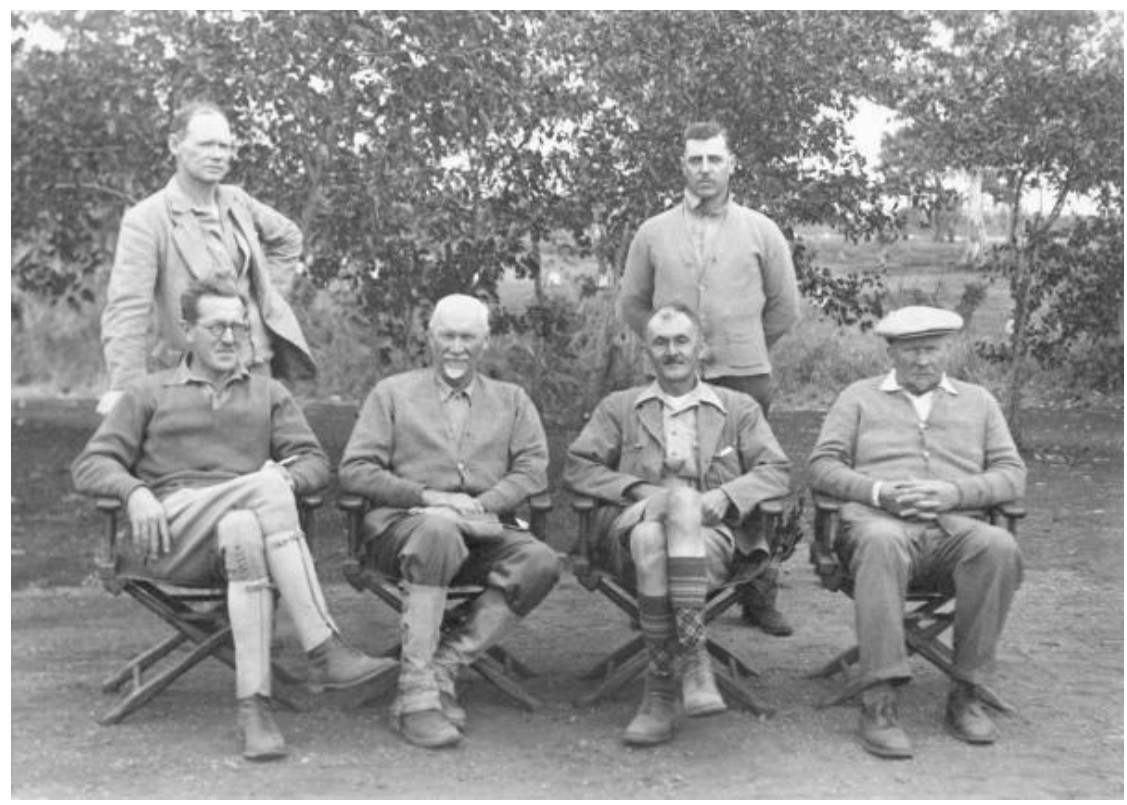

Fonte: THE SOUTH AFRICAN ARCHAEOLOGICAL SOCIETY a, acesso em 25/10/2012.

Essa fotografia é muito significativa do interesse do primeiro-ministro sul-africano Smuts pelo potencial "político" e "ideológico" dos discursos veiculados pelos arqueólogos.

Figura 6 - Janette Deacon ministrando curso para a formação de guias locais do sítio arqueológico de Mapungubwe (2006).

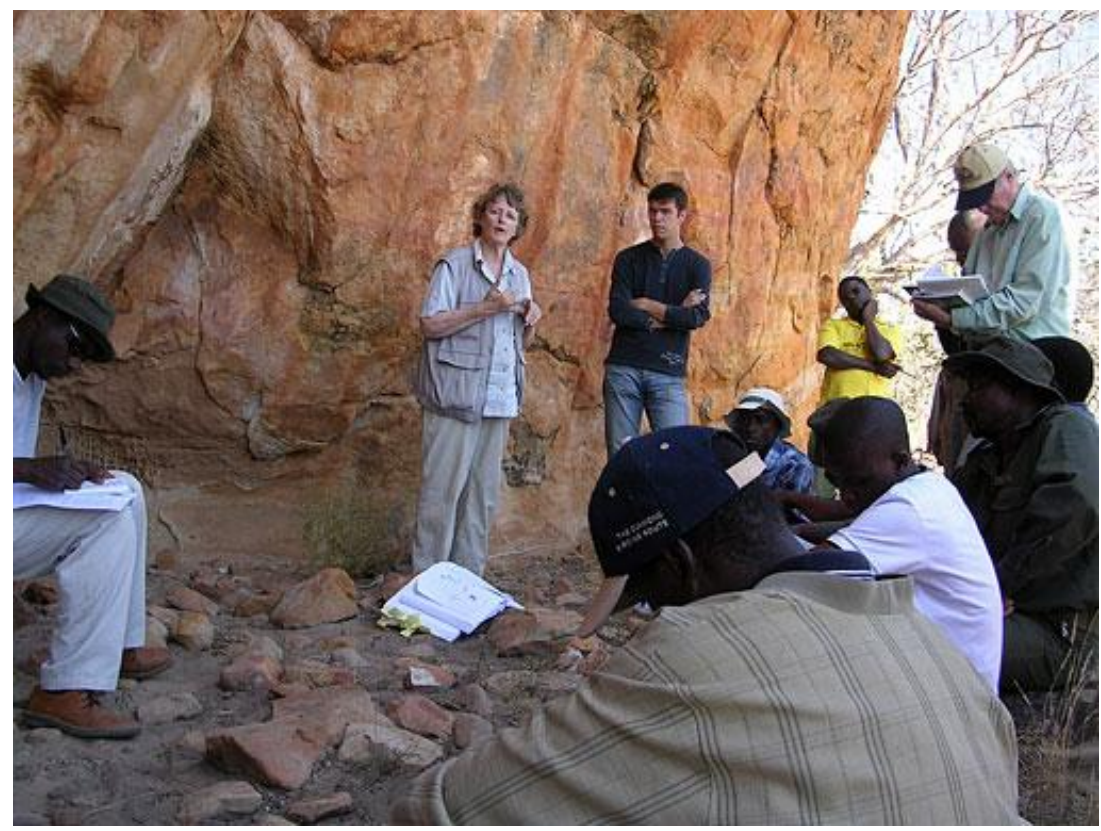

Fonte: GETTY CONSERVATION INSTITUTE. Créditos: Trinidad Rico, acesso em 04/11/2012.

A ex-editora Deacon, do boletim TSAAB, praticando a educação patrimonial, um dos temas mais abordados por ela nos seus editoriais. 
Figura 7 - Entrada do sítio Nelson Bay Cave, localizado em Western Cape, África do Sul, s.d.

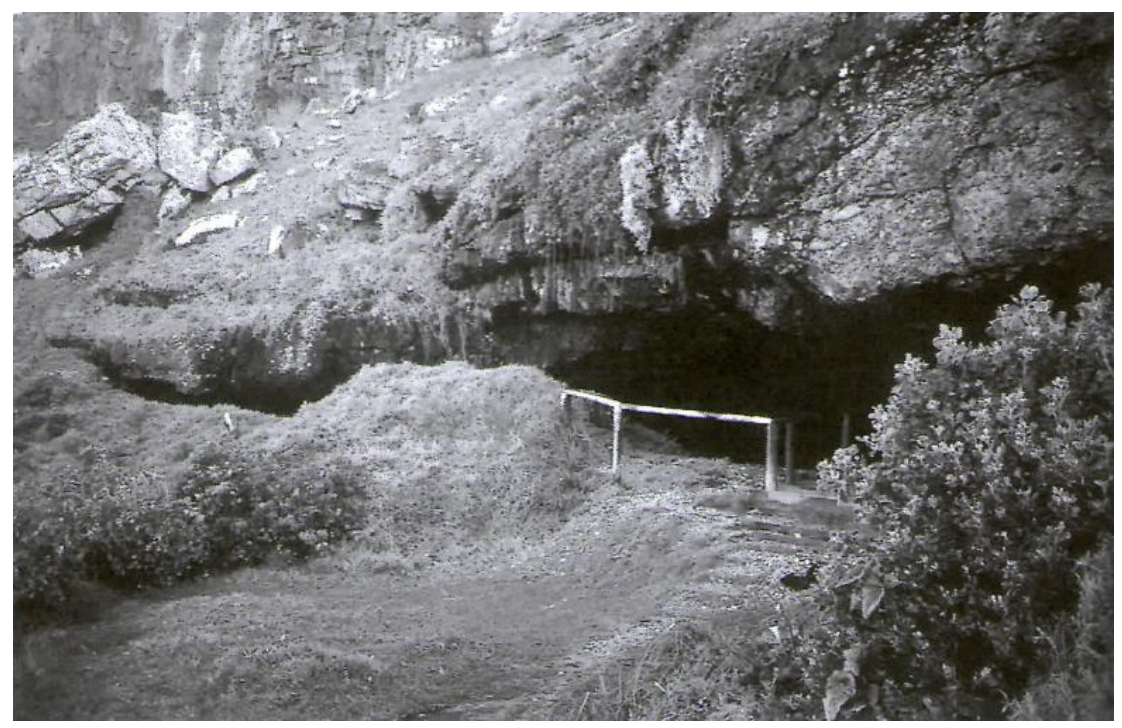

Fonte: MITCHELL, 2002, p.176.

Um dos sítios arqueológicos que a ex-editora Deacon atuou objetivando a sua musealização e a sua preservação contra os "vândalos", segundo ela.

Figura 8 - Hilary John Deacon, 2007.

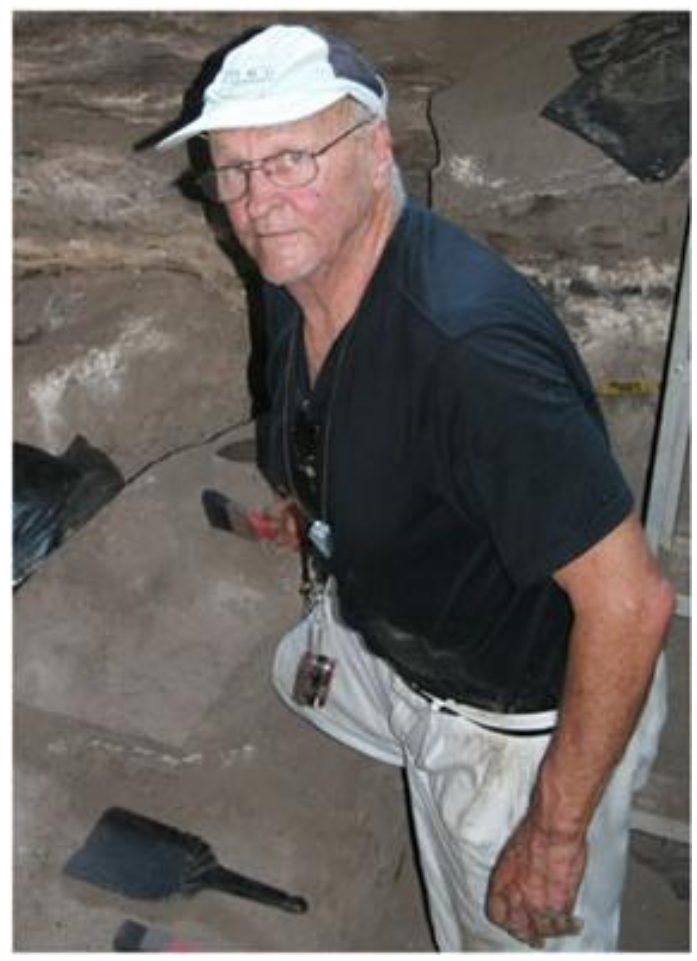

Fonte: SCHRIRE, 2010, p.02.

H.J. Deacon, um dos editores convidados do TSAAB, marido de Janette, fotografado no "campo" poucos anos antes do seu falecimento. 
Figura 9 - Martin Hall, s.d.

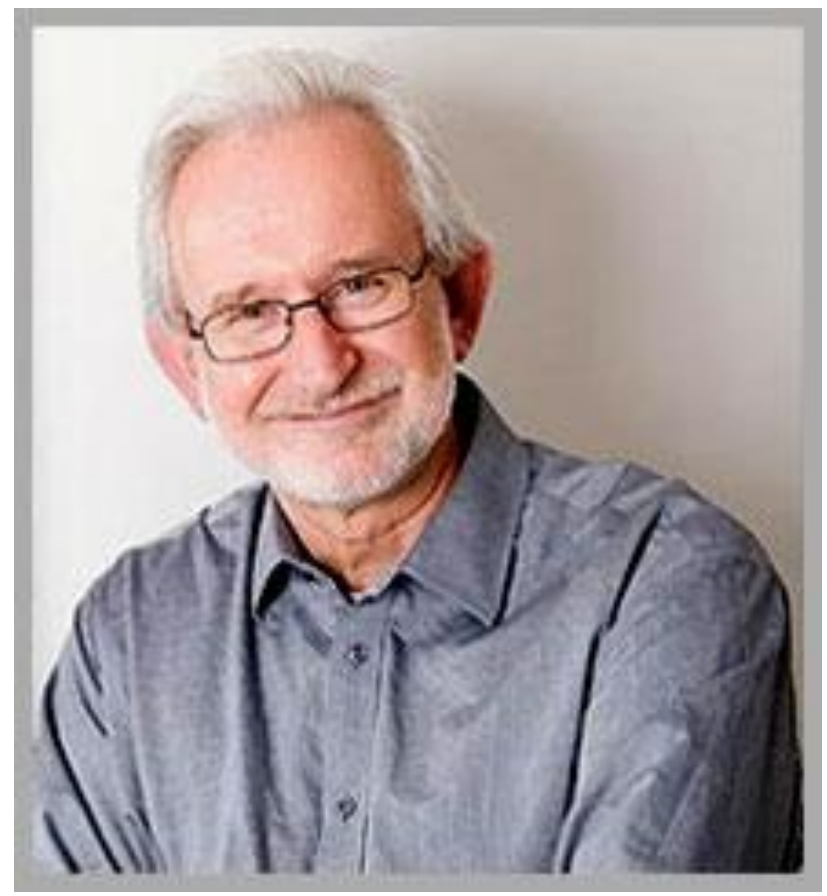

Fonte: UNIVERSITY OF SALFORD b, acesso em 04/11/2012.

Segundo Shepherd (2000), Hall, um dos editores convidados do TSAAB, é um dos arqueólogos sul-africanos mais progressistas atualmente.

Figura 10 - Jannie Loubser, s.d.

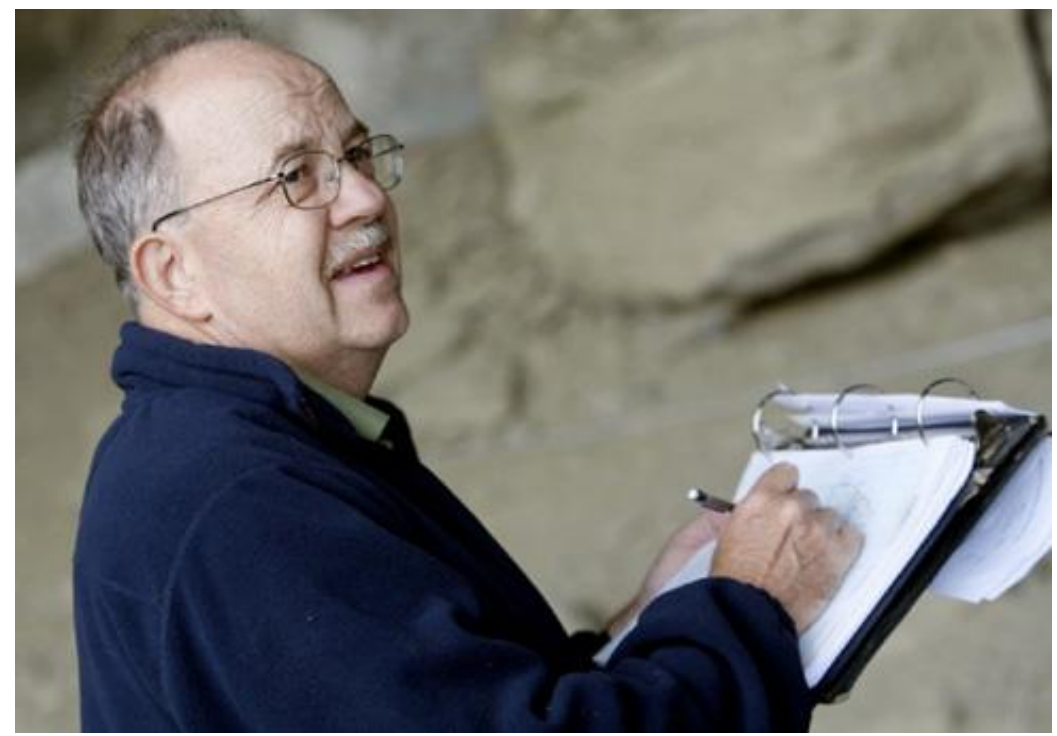

Fonte: CASEY PAGE / BILLINGS GAZETTE, acesso em 04/11/2012.

Loubser, editor convidado do TSAAB, muito atuante na arqueologia de contrato, analisando arte rupestre no "campo", em um sítio não identificado. 


\section{Figura 11 - Aron Mazel no centro, s.d.}

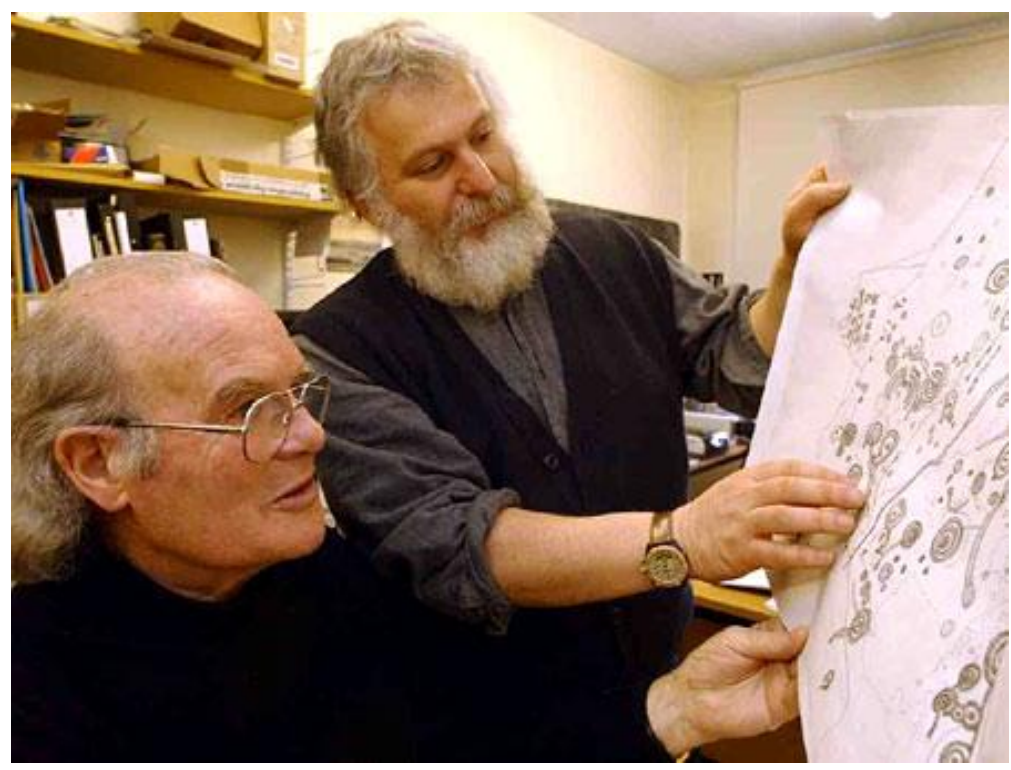

Fonte: NEWCASTLE UNIVERSITY b, acesso em 04/11/2012.

Segundo Ucko (1987), Mazel, um dos editores convidados do TSAAB, foi um dos arqueólogos que mais insistiram em participar do WAC-86 mesmo sabendo do pedido de boicote proposto pela ANC, organização política de Mandela, e pela ONU ao regime segregacionista.

\section{Figuras 12 a 14 não apresentam fotografias.}

Figura 15 - Peter L. Shinnie, s.d.

Fonte: DAVID, 2008, p.125.

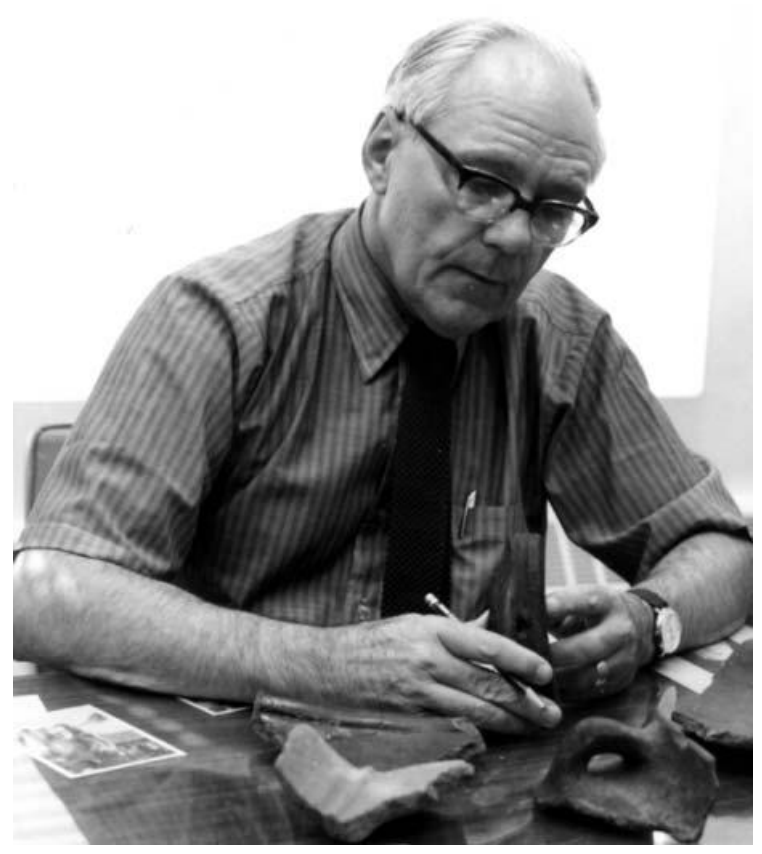

Shinnie, primeiro editor do Nyame Akuma, trabalhando no gabinete. Ao participar da guerra como aviador, desenvolveu a prática de realizar fotografias áreas dos sítios arqueológicos do norte da África. Segundo David (2008), o editor Shinnie trabalhou pela "descolonização da arqueologia africana". 
Figura 16 - David Lubell, s.d.

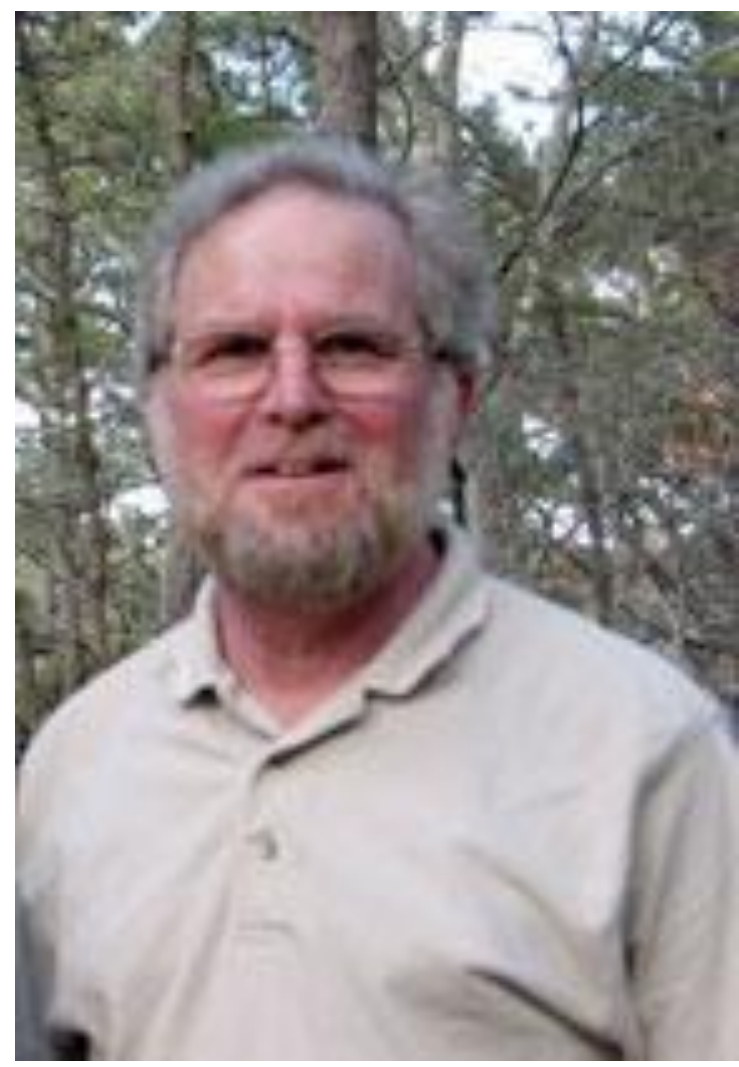

Fonte: UNIVERSITY OF WATERLOO b, acesso em 16/11/2012.

Lubell foi o terceiro editor do Nyame Akuma entre os anos de 1982 e 1988.

Figura 17 - John R. F. Bower, s.d.

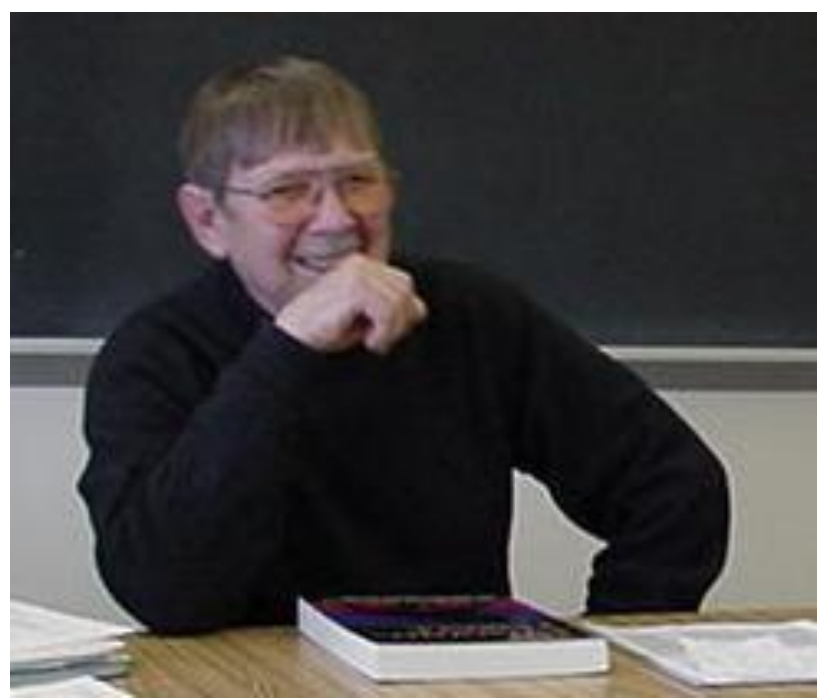

Fonte: UNIVERSITY OF MINNESOTA, acesso em 16/11/2012.

Bower foi o quarto editor do Nyame Akuma entre os anos de 1989 e 1993.

Figura 18 - não apresenta fotografia. 
Figura 19 - Detalhe das presas de elefante presentes nas capas do Nsi e na fachada do CICIBA

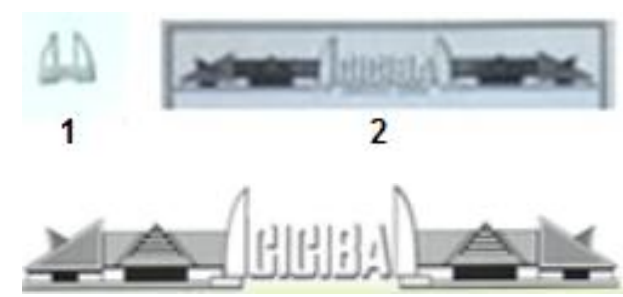

3

1.Detalhe da capa do Nsi, 1987, n.2

2.Detalhe da capa do Nsi, 1991, n.8-9

(AFRICAN-ARCHAEOLOGY.NET a)

3. Detalhe da logomarca do site

CICIBA.NET b, acesso em 15/12/2012.

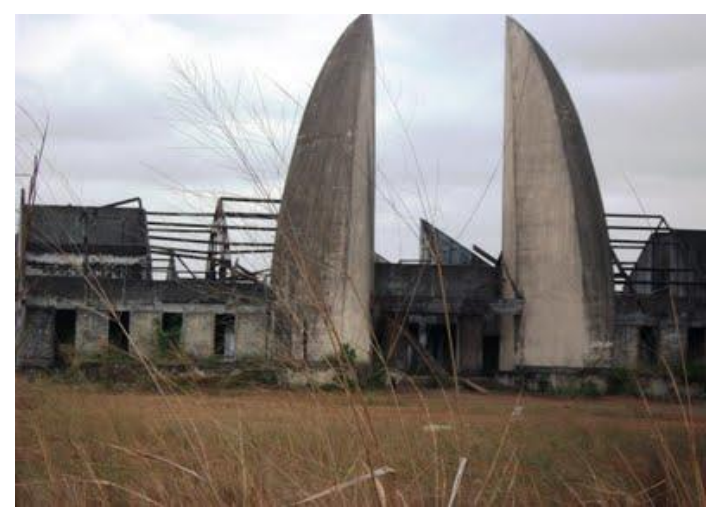

Fachada do edifício-sede abandonado do CICIBA. (GABONECO, 26/09/2011, acesso em $15 / 12 / 2012)$

Destacamos que a logomarca do boletim Nsi retratava a fachada completa do edifício-sede do CICIBA em Libreville, entretanto, este não chegou a ser concluído e foi abandonado.

Figura 20 - não apresenta fotografia.

Figura 21 - Cheikh Anta Diop, à esquerda e Théophile Obenga, à direita (1981).

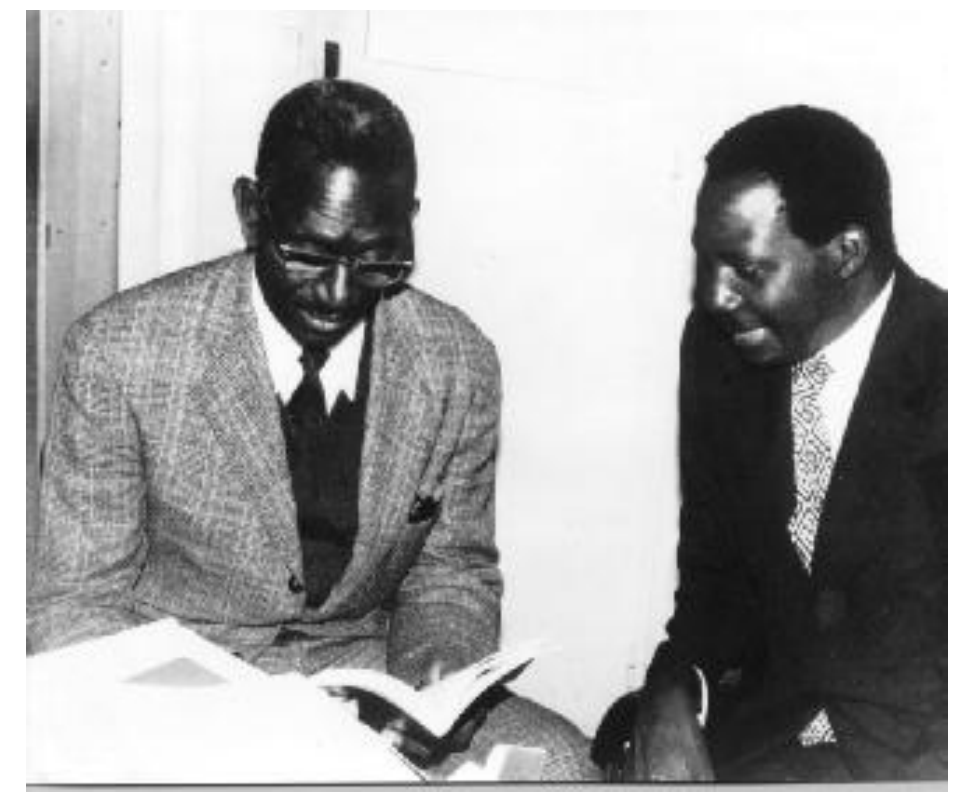

Fonte: REVUE ANKH, acesso em 20/11/2012.

Fotografia que representa a parceria e o companheirismo de Obenga, diretor do CICIBA, e Cheikh Anta Diop. 
Figura 22 - Bernard Clist, s.d.

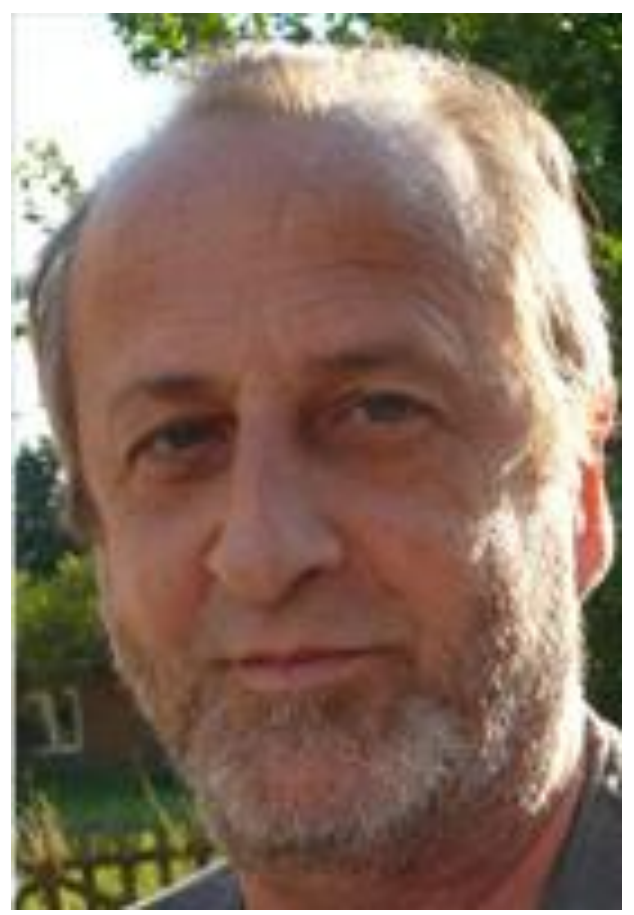

Fonte: THE ANTHROPOLOGY BACK DOOR TO THE WEB, acesso em 20/12/2012.

Clist foi editor do boletim Nsi entre 1987 e 1992.

Figura 23 - Raymond Lanfranchi, s.d.

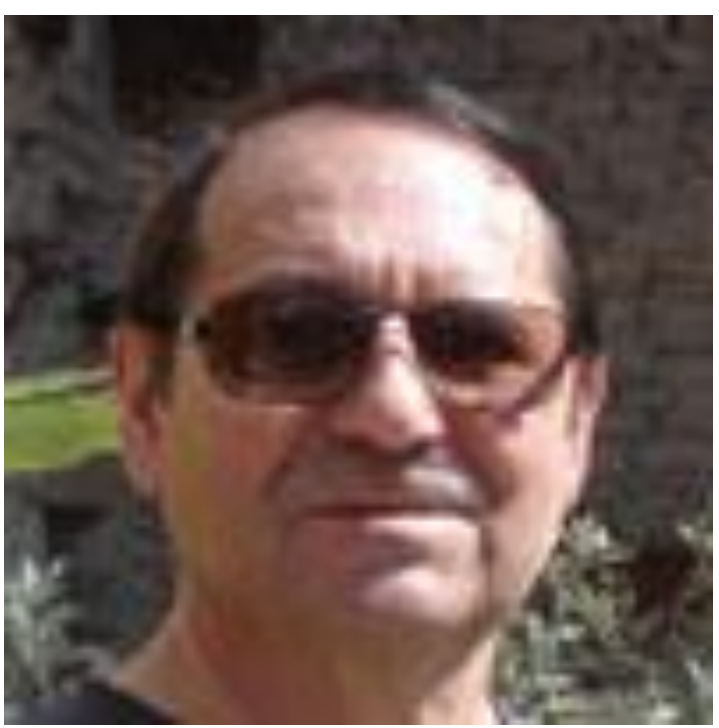

Fonte: KONGOKING PROJECT, acesso em 15/12/2012.

Lanfranchi foi editor do boletim Nsi entre os anos de 1987 e 1991. 


\section{REFERÊNCIAS BIBLIOGRÁFICAS}

ADEDEJI, A (2010). Estratégias comparadas da descolonização econômica In MAZRUI, A A; WONDJI, C. (Ed.). História Geral da África: VIII África desde 1935. Brasília: Unesco, pp. 471516. Acessado em 14/10/2012. Disponível em http://unesdoc.unesco.org/images/0019/001902/190256POR.pdf

AFRICA: Journal of the International African Institute. 1973. Notes and News, vol. 43, n. 2, april, pp.153-157, acesso em 16/12/2012, disponível em http://www.jstor.org/stable/1159328

AFRICABIB, acesso em 16/12/2012, disponível em http://www.africabib.org/query_p.php?PG=148

AFRICAN-ARCHAEOLOGY.NET a, acesso em 20/11/2012, disponível em http://www.africanarchaeology.net/Nsi/

AFRICAN-ARCHAEOLOGY.NET b, Nsi, 1987, n.2, acesso em 20/11/2012, disponível em http://www.african-archaeology.net/Nsi/nsi2.html

AFRICAN-ARCHAEOLOGY.NET c, Nsi, 1987, n.1, p.01, acesso em 20/11/2012, disponível em http://www.african-archaeology.net/Nsi/nsi1_1-2.pdf

ALDROVANDI, C.E.V. 2009. A imagética pretérita: perspectivas teóricas sobre a Arqueologia da Imagem. In. Revista do Museu de Arqueologia e Etnologia, São Paulo, n.19, pp.39-61.

AREIA, M.L.R. de. 2007. The Dundu Museum (Angola): project for its reopening and renovation. In: ALLSWORTH-JONES, P. (ed.). West African Archaeology: New developments, new perspectives. BAR International Series 2164. Acesso em 14/10/2012. Disponível em http://www.uc.pt/en/cia/people/pdfs/areia_actas_shefield

BAGODO, O .B. 2004. Archaeologies africanistes et afro-endogénes au sud du Sahara: quelles issues constructives au xxie siècle? In. 11 ${ }^{\text {th }}$ Pan African Congress Proceedings. Acessado em 13/03/2012, disponível em

http://www.panafprehistory.org/images/papers/ARCHEOLOGIES_AFRICANISTES_ET_AFROENDOGENES_AU_SUD_DU_SAHARA_QUELLES_ISSUES_CONSTRUCTIVES_AU_Xxie_SI ECLE_Obare_BBagodo.pdf

BALFOUR, H. 1929. Concerning Thunderbolts. In Folklore, vol.40, n.2, june, pp.168-172.

Acesso em 19/11/2012, disponível em

http://www.jstor.org/stable/pdfplus/1255833.pdf?acceptTC=true

BEDIN, O. 2003. Fatores de textualidade e discursividade no editorial. São Paulo: Universidade Presbiteriana Mackenzie, dissertação de mestrado.

BINFORD, L. 1964. A Consideration of Archaeological Research Design In. American Antiquity, vol. 29, n. 4, april, pp.425-441, acesso em 18/12/2012, disponível em http://www.jstor.org/stable/277978

BOBBIO, N. 1997. Os intelectuais e o poder: dúvidas e opções dos homens de cultura da sociedade contemporânea. Trad. Marco Aurélio Nogueira. São Paulo: Editora da Universidade Estadual Paulista.

BONHOMME, J. 2007. Anthropologue et/ou initié: L'anthropologie gabonaise à l'épreuve du Bwiti. In Journal des anthropologues, n.110-111, pp.02-11, acesso em 18/12/2012, disponível em http:// http://jda.revues.org/2444 
BOULAGA, F.E. 1993. L'intellectuel exotique. In. Politique Africaine, n.51, octobre, pp.26-34, acesso em 03/03/2012, disponível em http://www.politique-

africaine.com/numeros/pdf/051026.pdf

BURNS, T. 2006. A narrativa norte-americana e a Segunda Guerra Mundial. Aletria: Revista de estudos de literatura, vol.13, n.01, UFMG, p.144-154. Acesso em 03/08/2012. http://www.jstor.org/stable/1208724

CAPELATO, M.H. 2005. Cuadernos hispanoamericanos: ideias políticas numa revista de cultura. In Varia Historia, vol. 21, n.34, Belo Horizonte: Depto de História da Fafich-UFMG, p.344-370.

CAPELATO, M.H; PRADO, M.L. 1980. O Bravo Matutino: imprensa e ideologia no jornal O Estado de São Paulo. São Paulo: Editora Alfa-Ômega.

CASEY PAGE / BILLINGS GAZETTE, acesso em 04/11/2012, disponível em http://archaeologynewsnetwork.blogspot.com.br/2011/06/rock-are-expert-examines-fadingmontana.html

CHRÉTIEN, J.P. 1985. Les bantous, de la philologie allemande à l'authenticité Africaine: Un mythe racial contemporain. In. Vingtième Siècle: Revue d'histoire, n. 8, oct. - dec., pp. 43-66. Acesso em 19/11/2012, disponível em http://www.jstor.org/stable/3769205

CICIBA.NET a, acesso em 18/12/2012, disponível em http://www.ciciba.net/index.php/actualite/actualites/49-I-unesco-soutiendra-le-gabon-pourrehabiliter-le-ciciba

CICIBA.NET b, acesso em 18/12/2012, disponível em http://www.ciciba.net/

CLIST, B.; LANFRANCHI, R. 1989. Etats des estrutures de recherches archéologiques dans les etats-membres du CICIBA. In Nsi, n.6, p.139-150. Acesso em 20/11/2012, disponível em http://www.african-archaeology.net/Nsi/nsi6_139-150.pdf

COPANS, J. 1993. Intellectuels visibles, intellectuels invisibles. In Politique Africaine, n.51, octobre, intellectuels africains, pp.7-25, acesso em 03/03/2012, disponível em http://www.politique-africaine.com/numeros/pdf/051007.pdf

COPPENS, Y. 2010. Parte I: a hominização, problemas gerais. In Ki-Zerbo, J. (Ed.) História Geral da África, I: metodologia e pré-história da África. 2.ed. Brasília: Unesco, pp. 447-470. Acessado em 13/10/2012. Disponível em: http://unesdoc.unesco.org/images/0019/001902/190249POR.pdf

CORACINI, M. J. R. F. 2007. Um fazer persuasivo: o discurso subjetivo da ciência. 2.ed. Campinas, São Paulo: Pontes Editores.

CORNEVIN, M. 1998. Secrets du continent noir révelés par l'archaéologie. Paris : Maison Neuve et Larousse.

DAVID, N. (2008). Obituary: Peter Lewis Shinnie 1915- 2007. In African Archaeological Review, vol. 25, p.125-129, acesso em 03/03/2012, disponível em http://download.springer.com/static/pdf/609/art\%253A10.1007\%252Fs10437-008-9019z.pdf?auth66=1355243603_b1e91152413702b8daa358c507b49c99\&ext=.pdf

DE LUCA, T.R. 2010. A Revista do Brasil: um diagnóstico para a (n)ação. São Paulo: Editora Unesp. p. 35-84. 
DE MARET, P. (1985). Recent Archaeological Research and Dates from Central Africa In The Journal of African History, vol. 26, n.2, pp. 129-148, acesso em 22/11/2012, disponível em http://www.jstor.org/stable/181720.

DE MARET, P. 1990. Phases and facies in the archaeology of Central Africa. In ROBERTSHAW, P. (ed.) A History of African Archaeology. London: James Currey.

DECALO, S. 1989. Modalities of Civil-Military Stability in Africa In. The Journal of Modern African Studies, vol.27, n.4, dec., pp. 547-578. Acesso em 05/12/2012, disponível em http://www.jstor.org/stable/161109

DIOP, M. 2010. A África tropical e a África equatorial sob dominio francês, espanhol e português. In MAZRUI, A.A. ; WONDJI, C. (Eds). História geral da África, VIII: África desde 1935. - Brasília : UNESCO, pp. 67-88, acesso em 19/11/2012, disponível em http://unesdoc.unesco.org/images/0019/001902/190256POR.pdf

DIOUF, M. 1993. Les intellectuels africains face à l'interprise démocratique: entre la citoyenneté et l'expertise. In Politique Africaine, n.51, octobre, pp.35-47, acesso em 03/03/2012, disponível em http://www.politique-africaine.com/numeros/pdf/051035.pdf

DÖPCKE, W. 1998. Uma nova política exterior depois do apartheid? - Reflexões sobre as relações regionais da África do Sul, 1974 - 1998. Rev. Bras. Polít. Int., vol. 41, n.1, pp.133161, acesso em 25/11/2012, disponível em http://www.scielo.br/pdf/rbpi/v41n1/v41n1a07.pdf

DRAFT AGREEMENT BETWEEN UNESCO AND THE INTERNATIONAL CENTRE FOR THE BANTU CIVILIZATIONS (CICIBA), 12 september 1986. Paris, UNESCO, session 125, n.125 ex/31 rev., item 6.6 of the agenda, acesso em 18/12/2012, disponível em http://unesdoc.unesco.org/images/0006/000696/069614eo.pdf

DUFAU, H. 1988. Informations. Revue Politique Africaine: Mozambique : guerre et nationalismes, n.29, mars, pp. 133-137, acesso em 15/12/2012, disponível em http://www.politique-africaine.com/numeros/pdf/029133.pdf

DYSON, S. L. 1985. Two paths to the past: a comparative study of the last fifty years of American Antiquity and the American Journal of Archaeology. In. American Antiquity, vol.50, n.2, pp. 452-463, acesso em 19/12/2012, disponível em http://www.jstor.org/stable/280503

EARLY, G. 1994. Afrocentrism: from sensationalism to measured deliberation. The Journal of blacks in higher education, n.5, autumn, pp.86-88, acesso em 07/12/2012, disponível em http://www.jstor.org/stable/2962415

EMPRESA STRATUM UNLIMITED, acesso em 04/11/2012, disponível em http://www.stratumunlimited.com/qualifications.html.

ENCYCLOPEDIA BRITANNICA ACADEMIC EDITION, acesso em 17/11/2012, disponível em http://www.britannica.com/EBchecked/topic/309336/Kabwe-cranium

FARIAS, P.F.M. 2003. Afrocentrismo: entre uma contranarrativa histórica universalista e o relatismo cultural. In Afro-Ásia, n.29-30, pp. 317-343, acesso em 15/12/2012, disponível em http://redalyc.uaemex.mx/redalyc/pdf/770/77003009.pdf

FERREIRA, A.G.C. (2010). Bibliometria na avaliação de periódicos científicos. In.

DataGramaZero - Revista de Ciência da Informação, v.11 n.3, jun/10. Acesso em 01/11/2012. Disponível em http://www.dgz.org.br/jun10/Art_05.htm

FOLORUNSO, C.A. West African perspective of the World Archaeological Congress: challenges and aspirations. In Archaeologies: Journal of the World Archaelogical Congress, vol.3, n.1, april, acesso em 13/03/2012, disponível em 
http://download.springer.com/static/pdf/169/art\%253A10.1007\%252Fs11759-007-9003-

2.pdf?auth66=1355243728_584652e01bad529591f1de9dd693e4cf\&ext=.pdf

FOUCAULT, M. 1972. A arqueologia do saber. Tradução Luiz Felipe Baeta Neves. Petrópolis, Lisboa: Vozes, Centro do Livro Brasileiro.

GABEL, C. 1985. Archaeology in sub-Saharan Africa. In. The International Journal of African Historical Studies, v.18, n.2, pp.241-264. Acesso em 04/12/2012, disponível em http://www.jstor.org/stable/pdfplus/217742.pdf?acceptTC=true

GABONECO, acessado em 26/09/2011, disponível em

http://www.bdpgabon.org/articles/2011/09/26/gabon-le-ministere-de-l\%E2\%80\%99habitatbientot-devant-la-justice/

GETTY CONSERVATION INSTITUTE. Créditos: Trinidad Rico, acesso em 04/11/2012, disponível em http://www.getty.edu/conservation/our_projects/field_projects/sarap/sarap25.html

GOLSON, J. 1986. The World Archaeological Congress, Southampton, and its aftermath. In Australian Archaeology, n.23, pp.100-105, acesso em 18/12/2012, disponível em http://www.library.uq.edu.au/ojs/index.php/aa/article/view/1582/1569

GOODELL, G.E. 1985. Paternalism, patronage and potlatch: the dynamics of giving and being given to. In. Current Anthropology, vol.26, n.2, april, pp.247-257. Acesso em 10/12/2012, disponível em http://www.jstor.org/stable/2743138

GOODRUM, M.R. 2009. The creation of the societies for the study of prehistory and their role in the formation of prehistoric archaeology as a discipline, 1867 - 1929. In Bulletin of the history of archaeology, vol, 19, n.2, p.27-35. Acesso em 04/04/2012, disponível em http://www.archaeologybulletin.org/article/view/bha.19204/74

GOODWIN, A.J.H. 1945. Editorial Notes and News In The South African Archaeological Bulletin, vol.1, n.1, dez., p. 1-4 disponível em http://www.jstor.org/stable/pdfplus/3886661.pdf?acceptTC=true

GOODWIN, A.J.H. 1946a. Earlier Middle and Later. In The South African Archaeological Bulletin, vol.1, n.3, julho, pp. 74-76. Acessado em 19/02/2012. http://www.jstor.org/stable/38877275

GOODWIN, A.J.H. 1946b. The Terminology of Prehistory. In The South African Archaeological Bulletin, vol. 1, n.4, November, pp. 91-100. Acessado em 19/12/2011. http://www.jstor.org/stable/3887518

GOODWIN, A.J.H. 1946c. Editorial In The South African Archaeological Bulletin, março, vol. 1, n.2, p. 29-32, acesso em 17/11/2012, disponível em http://www.jstor.org/stable/3887159?seq=1

GOOGLE BOOKS, acesso em 15/11/2012, disponível em http://books.google.com.br/books?id=Lh4tAQAAIAAJ\&hl=ptBR\&source=gbs_book_other_versions

GOOGLE EARTH, acesso em 19/12/2012, disponível em http://www.google.com/earth/index.html

GRAHAM, M.J. 1999. The African-Centred World view: Developing a Paradigm for Social Work In British Journal of Social Work, v.29, n.2, pp.251-267, acesso em 15/12/2012, disponível em http://bjsw.oxfordjournals.org/content/29/2/251.full.pdf+html 
HAHN, R. 1971. The anatomy of a scientific institution: The Paris Academy of Science, 1666-1803. Berkeley, Los Angeles, London: University California Press.

HARDIN, R. 1998. Session I: dinamiques du passe. In Bulletin Series Yale School of Forestry and Environmental Studies, n.102, p. 33-41, acesso em 22/11/2012, disponível em http://www.yale.edu/sangha/PDF_FILES/FRENCH_.PDF/1SECTION/HARDIN.PDF

HASSAN, F.A. 1999. African Archaeology: the call of the future. In African Affairs, 98, pp.393406, acesso em 03/03/2012, disponível em

http://www.jstor.org/stable/pdfplus/723526.pdf?acceptTC=true

HAUGHTON, S.H. 1960. Prof. A.J.H. Goodwin. In Nature, n.4727, june 4, p.761. disponível em http://www.nature.com/nature/journal/v186/n4727/pdf/186761a0.pdf

HENRY, P.M. 1984. Rapport de mission Afrique: Centre International des Civilisations Bantu (CICIBA). Paris, UNESCO, 08 de outubro, oㅡ série: FMR/CLT/CS/84/258 (UNDP), acesso em 03/04/2012, disponível em http://unesdoc.unesco.org/images/0006/000616/061659fb.pdf

HERMENS, R. de B. des. 2010. Pré-história da África central: parte I. In Ki-Zerbo, J. (Ed.) História Geral da África, I: metodologia e pré-história da África. 2.ed. Brasília: Unesco, pp.592-613. Acessado em 14/10/2012. Disponível em http://unesdoc.unesco.org/images/0019/001902/190249POR.pdf

HODDER, I. 1996. Theory and practice in archaeology. London; New York, Routledge.

HODDER, I. 1989. Writing archaeology: site reports in context. In Antiquity, vol 63, pp. 268274.

HODDER, I. 2003. Archaeological reflexivity and the local voice. In: Anthropological Quarternaly, v.76, n.1, pp.55-69, winter, 2003.

HOUNTONDJI, P.J. 1995. Producing Knowledge in Africa Today, The Second Bashorun M.K.O. Abiola Distinguished Lecture. In African Studies Review, vol. 38, n. 3, December, pp.01-10. Acessado em 09/04/2012.

http://www.jstor.org/discover/10.2307/524790?uid=3737664\&uid=2\&uid=4\&sid=2110084462174 1

HOUNTONDJI, P.J. 2008. Conhecimento de África, conhecimento de Africanos: duas perspectivas sobre os estudos africanos. Revista Crítica de Ciências Sociais, 80, março: pp.149-160. Acessado em 09/04/2012. www.ces.uc.pt/rccs/includes/download. php?id=983

INDIANA UNIVERSITY, acesso em 19/12/2012, disponível em http://www.indiana.edu/ origins/teach/P314/p3142000week2.html

ISAAC; G.; CLARK, J.D.; DAVISON, C.; HOWELL, F.C. 1973. Towards an Association of Africanist Archaeologists In. Nyame Akuma, n.3, outubro, p.2-4, acesso em 11/11/2012, disponível em http://safa.rice.edu/Nyame_Akuma_TOCs/Nyame_Akuma_Issue_3/

JSTOR a, acesso em 03/11/2012, disponível em http://www.jstor.org/stable/3886660

JSTOR b, acesso em 03/11/2012, disponível em http://www.jstor.org/stable/3886661 ?seq=1

KAREGA-MUNENE, K. ; SCHMIDT, P. (2010). Postcolonial archaeologies in Africa; breaking the silence. In African Archaeological Review, v.27, n.4, december, pp.323-337. Acesso em 03/04/2012, disponível em http://web.ebscohost.com/ehost/detail?vid=3\&hid=17\&sid=9e9f1663$4 \mathrm{f} 4 \mathrm{c}-4 \mathrm{e} 8 \mathrm{f}-92 \mathrm{~d} 4-$

d3af45b1cd92\%40sessionmgr14\&bdata=Jmxhbmc9cHQtYnlmc2I0ZT1laG9zdC1saXZl\#db=aph $\& A N=55813598$ 
KELLEY, J.H.; WILLIAMSON, R.F. 1996. The Positioning of Archaeology within Anthropology: A Canadian Historical Perspective In. American Antiquity, vol. 61, n.1, jan., pp. 5-20. Acesso em 10/12/2012, disponível em http://www.jstor.org/stable/282294 .

KIBUNJIA, M. 1997. The management of archaeological collections and resources in Africa. African Archaeological Review, v.14, n.1, p.137-141.

KING, D.W.; TENOPIR, C. 1998. A publicação de revistas eletrônicas: economia da produção, distribuição e uso. In: Ci. Inf., Brasília, v.27, n.2, p.176-182, mai/ago. Acesso em: 10/12/2012. Disponível em: http://www.scielo.br/pdf/ci/v27n2/king.pdf.

KONGOKING PROJECT. acesso em 15/12/2012, disponível em http://www.kongoking.org/partners.html

LANNES, S.C. da S. 2010. Editorial. Ciênc. Tecnol. Aliment. Campinas, vol.30, n.1, jan-mar., p.1. Acessado em 20/07/2012. http://www.scielo.br/pdf/cta/v30n1/v30n1a01.pdf

LESLIE, M.; SEALY, J.; TRACKERAY, A. 2000. Editorial. In The South African

Archaeological Bulletin, vol. 55, n. 172, dezembro, p. 87-89. Acesso em 19/12/2011, disponível em http://www.jstor.org/stable/3888958

LEVINE. P. 1986. The amateur and the professional: antiquarians, historians and archaeologists in Victorian England, 1838-1886. Cambridge: Cambridge University Press.

LIMB, P. 2005. The digitization of Africa In Africa Today, v.52, n.2, p. 03-19, winter. Disponível em: http://muse.jhu.edu/login?uri=/journals/africa_today/v052/52.2limb.pdf. Acesso em: $18 / 10 / 2009$.

LOPES, E. A . 2002. A construção discursiva de identidades em editoriais jornalísticos: MST e a nação. São Paulo: FFLCH-USP, dissertação de mestrado.

LUDOVICCAREME.COM, acesso em 19/12/2012, disponível em http://www.ludoviccareme.com/pt/serie/2/retratos

LYMAN, R.L.; O'BRIEN, M.J.; SCHIFFER, M.B. 2005. Publishing archaeology in Science and Scientific American, 1940-2003. In. American Antiquity, 70 (1), pp. 157-167. Disponível em http://www.jstor.org/stable/40035274

M'BOKOLO, E. 2010. África Equatorial do Oeste. In MAZRUI, A.A. ; WONDJI, C. (eds). História geral da África, VIII: África desde 1935. - Brasília : UNESCO, pp. 229-260.Acesso em 19/11/2012, disponível em http://unesdoc.unesco.org/images/0019/001902/190256POR.pdf

M'BOKOLO, E. 2011. África Negra: história e civilizações. Tomo II (do século XIX aos nossos dias). Trad. Manuel Resende. Salvador: Edufba; São Paulo: Casa das Áfricas.

MACGAFFEY, W. 1982. The Policy of National Integration in Zaïre. In. The Journal of Modern African Studies, vol. 20, n. 1, mar., pp. 87-105, acesso em 16/12/2012, disponível em http://www.jstor.org/stable/160377

MACHADO, R. 1981. Ciência e Saber: a trajetória da arqueologia de Michel Foucault. 2.ed. Rio de Janeiro: Edições Graal.

MALAN, B.D. 1955. The South African Archaeological Society: ten years of archaeology in South Africa. In. The South African Archaeological Bulletin, vol.11, n.42, junho, pp.31-40. Acesso em 03/11/2012, disponível em http://www.jstor.org/stable/3887174

MAMA, A . 2004. Critical capacities: facing the challenges of intellectual development in Africa. Inaugural lecture Prince Claus chair in development and equity, Institute of Social 
Studies of Erasmus University Rottherdam, 28 april 2004: p.01-17. Acessado em 27/03/2012. http://princeclauschair.nl/storage/documents/08Mama_PrinceClausInaugural_.pdf

MAZRUI, A A; WONDJI, C. (ed.). 2010. Introdução In História Geral da África: VIII África desde 1935. Brasília: Unesco, pp.01-29. Acessado em 14/10/2012. Disponível em http://unesdoc.unesco.org/images/0019/001902/190256POR.pdf

MBOT, J.E. 1991. Introduction. In OBENGA, T.; SOUINDOULA, S. (ed). Racines Bantu. Libreville, Paris; CICIBA, Sépia, p.7-12.

MCBREARTY, S. 1999. Society of Africanist Archaeologists In Evolutionary Anthropology: issues, news and reviews. vol.8, n.1, p. 1-3, acesso em 11/11/2012, disponível em http://onlinelibrary.wiley.com/doi/10.1002/(SICl)1520-6505(1999)8:1\%3C1::AID-

EVAN1\%3E3.0.CO;2-2/pdf

MENEGHINI, R.; PACKER, A.L. 2007. Is there science beyond English? In Embo Reports, vol.8, n.2, pp.112-116, acesso em 16/12/2012, disponível em http://www.nature.com/embor/journal/v8/n2/pdf/7400906.pdf

MENESES, U.B. de. 2003. Identidade cultural e arqueologia. In. BOSI, A . (org.). Cultura Brasileira: temas e situações. 4.ed. São Paulo: Ática, pp.182-190. (série fundamentos)

METZ, S. 1996. Reform, Conflict, and Security in Zaire, 5 de junho, acesso em 16/12/2012, disponível em http://www.strategicstudiesinstitute.army.mil/pdffiles/pub203.pdf

MIRANDA, D.B. de; PEREIRA, M.N.F. 1996. O periódico científico como veículo de comunicação: uma revisão de literatura. In. Ciência da Informação, v.25, n.3, p.375-382, set/dez.

MITCHELL, P. 2002. The Archaeology of Southern Africa. Cambridge: Cambridge University Press. (Cambridge World Archaeology).

MORO-ABADIA, O . 2006. The history of archaeology as a "colonial" discourse". In Bulletin of the history of archaeology, v.16, n.2. pp.04-17. Acesso em 13/03/2012, disponível em http://www.archaeologybulletin.org/article/view/bha.16202

MUNANGA, K. 1983. Antropologia Africana: mito ou realidade? In Revista de Antropologia, n.26, pp.151-160.

MURRAY, T. (ed.). 2001. Encyclopedia of archaeology: history and discoveries. Santa Barbara, California, Oxford: ABC-CLIO.

NASCIMENTO, E. L. 1996. Introdução às antigas civilizações africanas, in Sankofa: matrizes africanas da Cultura Brasileira, Org. E. L. Nascimento, Rio de Janeiro: Universidade do Estado do Rio de Janeiro.

NDLOVU, N. (2005). Incorporating indigenous management in rock art sites in KwazuluNatal. Grahamstown: Rhodes University (tese). Acesso em 27/11/2012, disponível em http://eprints.ru.ac.za/1380/1/Ndlovu-MA-TR05-170.pdf

NÈGRI, V. 2009. A overview of formal legislation on immovable cultural heritage in Africa. In. NDORO, W.; PWITI, G. (ed.). Legal frameworks for the protection of immovable cultural heritage in Africa. ICCROM - UNESCO, pp. 5-8, (ICCROM conservation studies, 5), acesso em 09/12/2012, disponível em http://www.iccrom.org/pdf/ICCROM_ICS05_LegalFrameworkAfrica_en.pdf 
NEWCASTLE UNIVERSITY A, acesso em 04/11/2012, disponível em http://www.ncl.ac.uk/sacs/staff/profile/aron.mazel\#tab_research).

NEWCASTLE UNIVERSITY B, acesso em 04/11/2012, disponível em http://rockart.ncl.ac.uk/interactive/outreach/peoplegallery/stan_aron_office.htm

NYAME AKUMA SUMÁRIO A, 1993. Contents, n. 39, junho, acesso em 18/12/2012, disponível em http://safa.rice.edu/Nyame_Akuma_TOCs/Nyame_Akuma_Issue_39/

NYAME AKUMA SUMÁRIO B, 1993. Contents, n.40, dezembro, acesso em 18/12/2012, disponível em http://safa.rice.edu/Nyame_Akuma_TOCs/Nyame_Akuma_Issue_40/

OLIVEIRA, E. C. 1996. Revistas Eletrônicas: papel ou bytes? In Informare - Cad. Prog. PósGrad. Ci. Inf. Rio de Janeiro, v. 2, n.1, p.81-87, jan/jun. Disponível em: http://www.brapci.ufpr.br/documento.php?dd0=0000003660\&dd1=06455. Acesso em: 14/09/2009.

PATTERSON, T.C. 1986. The Last Sixty Years: Toward a Social History of Americanist Archeology in the United States In. American Anthropologist, New Series, vol. 88, n. 1, march, pp. 7-26, acesso em 16/12/2012, disponível em http://www.jstor.org/stable/679276

PATTERSON, T.C. 1999. The Political Economy of Archaeology in the United States In Annual Review of Anthropology, vol. 28, pp. 155-174, acesso em 10/12/2012, disponível em http://www.jstor.org/stable/223391

PAVAN, C. 1988. A função das sociedades científicas. São Paulo: Academia de Ciências do Estado de São Paulo, publicação aciesp no62.

PHILLIPSON, D.W. 1988. Nsi: Bulletin de liaison des archéologues du monde bantu In. The Journal of African History, vol.29, n.2, p.365. Acesso em 27/07/2012, disponível em http://www.jstor.org/stable/182423

PHILLIPSON, D. W. 2005. African Archaeology. 2.ed. Cambridge: Cambridge University Press.

POSNANSKY, M. 1996. Coping with collapse in the 1990: West african museums, universities, and national patrimonies. In SCHMIDT, P.R.; MCINTOSH, R. (Ed.) Plundering Africa's past. Bloomington \& Indianapolis, London: Indiana University Press, James Currey, p. 143-163.

POSNANSKY, M. 2010. Introdução ao fim da pré-história na África subsaariana. In MOKHTAR, G. (Ed.). História Geral da África, II: África Antiga. Brasília: Unesco, pp. 585-606. Acessado em 14/10/2012. Disponível em http://unesdoc.unesco.org/images/0019/001902/190250POR.pdf

PWITI, Gilbert. Taking african cultural heritage management into the twenty-first century. In. African Archaeological Review, v.14, 81-83, 1991.

RAKOTOMAMONJY, B. 2009. Protection juridique du patrimoine culturel immobilier: orientations pour les pays francophones de l'Afrique subsaharienne. ICCROM - UNESCO (ICCROM conservation studies, 9), acesso em 09/12/2012, disponível em http://www.iccrom.org/pdf/ICCROM_ICS09_ProtectionJuridique_fr.pdf

REED, M.C. 1987. Gabon: A Neo-Colonial Enclave of Enduring French Interest In. The Journal of Modern African Studies, vol. 25, No. 2, Jun., pp. 283-320. Acesso em 05/12/2012, disponível em http://www.jstor.org/stable/161015

REILLY, C. 1998. An interview with Joseph Heller conducted by Charlie Reilly. Contemporary Literature, vol.39, n.04, winter, University of Wiscosin Press, p.507-522. Acessado em 03/08/2012. http://www.jstor.org/stable/1208724 
RENFREW, C.; BAHN, P. 1993. Arqueologia: teorías, métodos y práctica. Barcelona: Ediciones Akal.

REVUE ANKH, acesso em 20/11/2012, disponível em http://www.ankhonline.com/obenga_th_bibli.htm

ROBERTSHAW, P. 1979. The first archaeological excavation in Southern Africa? In: The South African Archaeological Bulletin, vol. 34, n.129, junho, p. 52-53. Acesso em 03/11/2012, disponível em www.jstor.org/stable/3888171

ROBERTSHAW, P. (ed.) 1990. Introduction. In A History of African Archaeology. London: James Currey,

ROBERTSHAW, P. 1994. Archaeological survey, ceramic analysis, and state formation in western Uganda. In. African Archaeological Review, v.12, n.1, p.105-131.

SAID, E.W. 2005. Representações do intelectual: as Conferências Reith de 1993. Trad. Milton Hatoum. São Paulo: Companhia das Letras.

SALUM, M.H.L. 1996. A madeira e seu emprego na arte africana: um exercício de interpretação a partir da estatuária tradicional bantu. Orientador: Prof.ำ Dr. Kabenguele Munanga. São Paulo: USP - FFLCH. (tese de doutoramento).

SAN FRANCISCO STATE UNIVERSITY, acesso em 16/12/2012, disponível em http://userwww.sfsu.edu/afrs/obenga.html

SARLO, B. 2005. Paisagens imaginárias: intelectuais, arte e meios de comunicação. 1.ed. Trad. Rubia Prates Goldoni e Sérgio Molina. São Paulo: Edusp.

SCHMALENBACH, W. (ed). 1988. African Art. Munich: Prestel-Verlag.

SCHMIDT, P.R. (ed). 2009. What is postcolonial about archaeologies in Africa? In Idem. Postcolonial archaeologies in Africa. Santa Fe [?]: SAR Press, pp.1-20. Acesso em 03/04/2012, disponível em

http://sarweb.org/media/files/sar_press_postcolonial_archaeologies_in_africa_chapter_1.pdf

SCHMIDT, P.R. 1995. Using archaeology to remake history in Africa. In. SCHMIDT, P.R.; PATTERSON, T.C. 1995. Making Alternative Histories: the practice of Archaeology in nonWestern settings. Santa Fe: School of America Research Press, pp.119-147.

SCHMIDT, P.R.; MCINTOSH, R.J. (1996). The african past endagered. In SCHMIDT, P.R.; MCINTOSH, R.J. (eds.) Plundering Africa's Past. Bloomington, London: Indiana University Press, James Currey Publishers, p.1-17.

SCHOENBRUN, D. 2001. Representing the Bantu Expansions: What's at Stake? In. The International Journal of African Historical Studies, Vol. 34, No. 1, pp. 1-4. Acesso em 05/12/2012, disponível em http://www.jstor.org/stable/3097284 .

SCHRIRE, Carmel. 2010. Hilary John Deacon: archaeologist (1936-2010) In South African Journal of Science, vol. 106, no11-12,p.1-2.

SCHULTZE, S. 2005. Características dos periódicos científicos produzidos por editoras universitárias brasileiras. Dissertação (mestrado) - Escola de Comunicações e Artes Universidade de São Paulo, São Paulo.

SEGOBYE, A.K. 2005. Weaving Fragments of the Past for a United Africa: Reflections on the Place of African Archaeology in the Development of the Continent in the 21st Century In The 
South African Archaeological Bulletin, Vol. 60, No. 182, dec., pp. 79-83. Acesso em 07/12/2012, disponível em http://www.jstor.org/stable/3889121

SHAW, I.; JAMESON, R. 2002. (ed.) A dictionary of archaeology. Oxford: Blackwell Publishers.

SHAW, Thurstan. The contemporary plundering of Africa's past. In. African Archaeological Review, v.14, n.01, p. 1-7, 1997.

SHEPHERD, N. 2000. World Archaeology in the White South: The fourth World Archaeological Congress, Cape Town, South Africa, 10-14 January 1999. In Public Archaeology, vol.1, pp.143-156.

SHEPHERD, N. 2002. The politics of archaeology in Africa. In. Annual Review of Anthropology, vol. 31, pp. 189-209. Acessado em 24/11/2012. http://www.jstor.org/stable/4132877

SHEPHERD, N. 2003. State of the discipline: science, cultura and identity in South African Archaeology. In Journal of Southern African Studies, vol. 29, n. 4, december, p.823-844. Acessado em 18/01/2012. http://www.jstor.org/stable/3557389

SHEPPERSON, G. 1962. Pan-Africanism and "Pan-Africanism": some historical notes. In Phylon, vol.23, n.4, pp.346-358. Acesso em 07/12/2012, disponível em http://www.jstor.org/stable/274158

SMART, P. 2005. Increasing the visibility of published research: African Journal Online In Africa Today, v.52, n.2, p. 39-53, winter. Disponível em:

http://muse.jhu.edu/login?uri=/journals/africa_today/v052/52.2smart.pdf. Acesso em: 18/10/2009.

SOCIETY OF AFRICANIST ARCHAEOLOGISTS A, acesso em 13/11/2012, disponível em http://safa.rice.edu/Nyame_Akuma_TOCs/Nyame_Akuma_Issue_1/

SOCIETY OF AFRICANIST ARCHAEOLOGISTS B, acesso em 13/11/2012, disponível em http://cohesion.rice.edu/CentersAndlnst/SAFA/emplibrary/NA\%2032\%20contents.pdf

STUMPF, I. R. C. 1996. Passado e Futuro das revistas científicas In Ciência da Informação, v.25, n.3, $6 p$, páginas não numeradas. Disponível em:

http://74.125.155.132/scholar?q=cache:TVpb9yjFYUIJ:scholar.google.com/+Stumpf,+lda+Regin a\&hl=pt-BR\&as_sdt=2000. Acesso em: 14/09/2009.

TAVARES, A P.; SANTOS, C.M. (ed.). 2002. Africae Monumenta: a apropriação da escrita pelos africanos. vol.1, Arquivo Caculo Cacahenda, Lisboa: Instituto de Investigação Científica Tropical.

TEFERRA, D. 2004. Striving at the periphery, craving for the centre: the realm of african schorlaly communication in the digital age In Journal of Schorlaly Publishing, v.35, n.3, p. 159-171, april. Disponível em:

http://muse.jhu.edu/login?uri=/journals/journal_of_scholarly_publishing/v035/35.3teferra.pdf. Acesso em: 18/10/2009.

THE ANTHROPOLOGY BACK DOOR TO THE WEB, acesso em 20/12/2012, disponível em http://www.clist.eu/Cv/cv.html 
THE SOUTH AFRICAN ARCHAEOLOGICAL BULLETIN. 1946. Foundation Members of the Society, vol.1, n.2, março, p. 52-56. Acesso em 03/11/2012, disponível em http://www.jstor.org/stable/3887169

THE SOUTH AFRICAN ARCHAEOLOGICAL BULLETIN, 1963, vol. 18, n. 70, Jul., p. 39, acesso em 17/11/2012, disponível em http://www.jstor.org/stable/pdfplus/3887503.pdf

THE SOUTH AFRICAN ARCHAEOLOGICAL SOCIETY A, acesso em 03/11/2012, disponível em http://www.archaeologysa.co.za/about_us

THE SOUTH AFRICAN ARCHAEOLOGICAL SOCIETY B, acesso em 03/11/2012, disponível em http://www.archaeologysa.co.za/images/uploads/ArchSoc_Constitution_SDV.pdf

THE SOUTH AFRICAN ARCHAEOLOGICAL SOCIETY C, http://www.archaeologysa.co.za/saab/static/about_the_south_african_archaeological_bulletin, acesso em 03/11/2012

TILLEY, C. 1989. Excavation as theatre. In Antiquity, vol 63: 275-280.

TOULABOR, C.M. 1993. Avant propôs: masque errant? In Politique Africaine, n.51, octobre, intellectuels africains, pp.3-6, acesso em 18/12/2012, disponível em http://www.politiqueafricaine.com/numeros/pdf/051003.pdf

TOURNEUX, H. (1983). Le Centre International des Civilisations Bantu (CICIBA) In Politique Africaine, n.09, mars 1983, p. 95-96. Acesso em 20/07/2012. Disponível em http://www.politique-africaine.com/numeros/pdf/009095.pdf

TRIGGER, B. G. 1990. The History of African Archaeology in World Perspective. In. ROBERTSHAW, Peter (ed.). A History of African Archaeology. London: James Currey.

TRIGGER, B.G. 1984. Alternative archaeologies: nationalist, colonialist, imperialist. In Man, new series, vol.19, n.3, sept., pp.355-370, acesso em 16/12/2012, disponível em http://www.jstor.org/stable/pdfplus/2802176.pdf?acceptTC=true

TRIGGER, B.G. 2004. História do pensamento arqueológico. Trad. Ordep Trindade Serra. São Paulo: Odysseus Editora.

UCKO, P.J. 1987. Freedom and apartheid: the story of world archaeological congress. London, Gerald Duckworth \& Co Ltd.

University of Minnesota, Duluth, acesso em 16/11/2012, disponível em http://www.d.umn.edu/ lbelote/srseminar/biographies2000.html).

UNIVERSITY OF SALFORD A, acesso em 04/11/2012, disponível em http://www.corporate.salford.ac.uk/leadership-management/martin-hall/biography/

UNIVERSITY OF SALFORD B, acesso em 04/11/2012, disponível em http://www.salford.ac.uk/university/university-structure/leadership-and-management/martinhall/publications

UNIVERSITY OF WATERLOO B, acesso em 16/11/2012, disponível em http://anthropology.uwaterloo.ca/lubell.html

UNIVERSITY OF WATERLOO A, acesso em 16/11/2012, disponível em http://watarts.uwaterloo.ca/ dlubell/Research.htm;http://watarts.uwaterloo.ca/ dlubell/Experienc e.htm 
VICTORA, C.G.; MOREIRA, C.B. 2006. Publicações científicas e as relações Norte-Sul: racismo editorial? In Revista Saúde Pública, 40, n.esp., pp.36-42, acesso em 18/12/2012, disponível em http://www.scielo.br/scielo.php?pid=S0034-

89102006000400006\&script=sci_abstract\&tlng=pt

WATKINS, M.H. (1937). A Grammar of Chichewa: A Bantu Language of British Central Africa. In Language, Vol. 13, No. 2, Language Dissertation No. 24, (Apr. - Jun.), pp. 5-7+9-158, acesso em 22/11/2012, disponível em URL: http://www.jstor.org/stable/522167

WICKS, E. 2000.State Sovereignty: towards a refined legal conceptualization. In AngloAmerican Law Review, n.29, pp.282-314, acesso em 16/12/2012, disponível em http://heinonline.org/HOL/Page?men_tab=srchresults\&handle=hein.journals/comlwr29\&id=306\& size=2\&collection=journals\&terms=Bayona\&termtype=phrase\&set_as_cursor=\#326

WITTER, G.P. 2007. Importância das sociedades/associações científicas: desenvolvimento da ciência e formação do profissional-pesquisador. Boletim de Psicologia, vol. 57, n.126: 01-14. Acessado em 20/07/2012. http://pepsic.bvsalud.org/pdf/bolpsi/v57n126/v57n126a02.pdf 